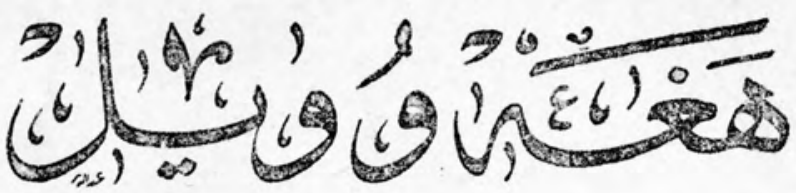

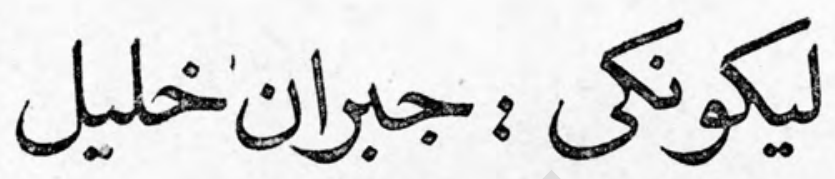

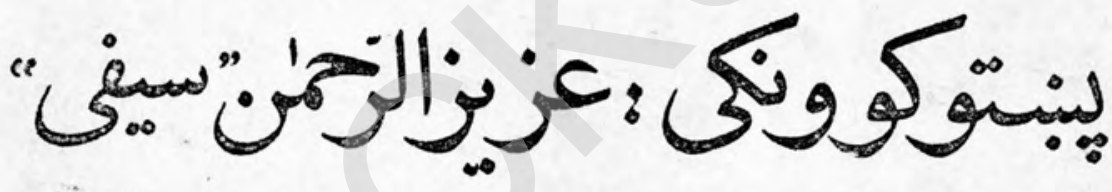

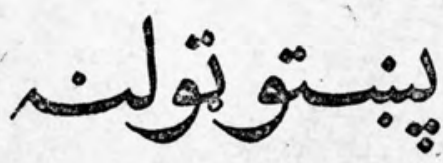



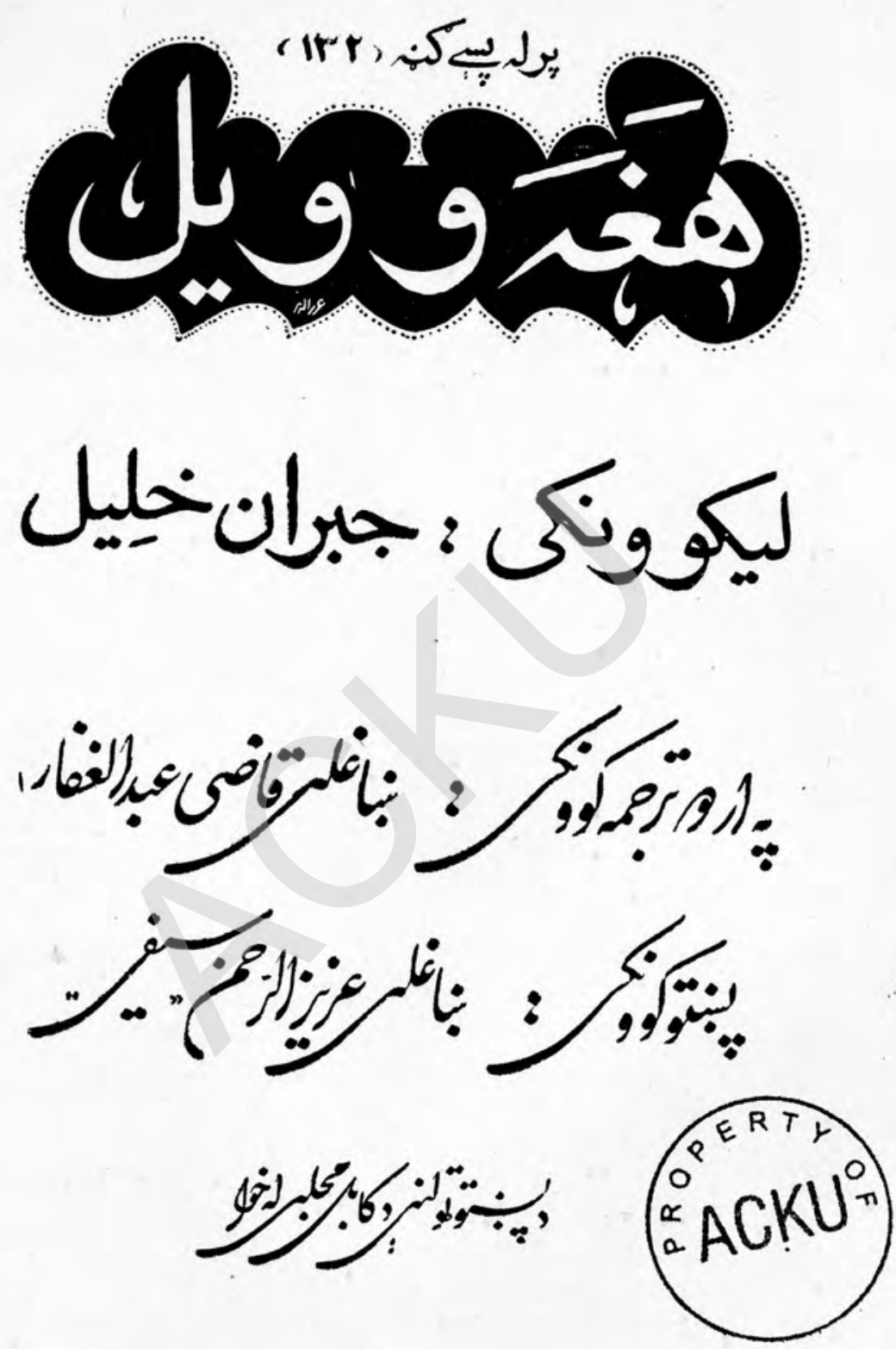

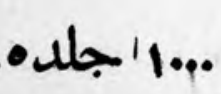

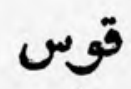

$$
\text { دطبع شمبر }
$$




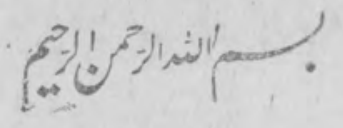

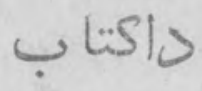

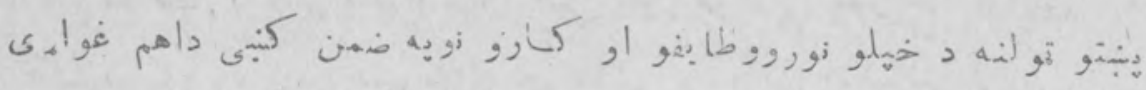

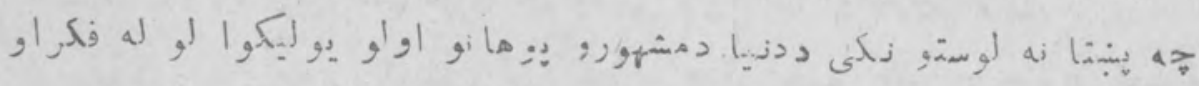

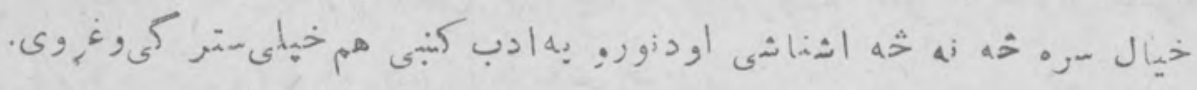

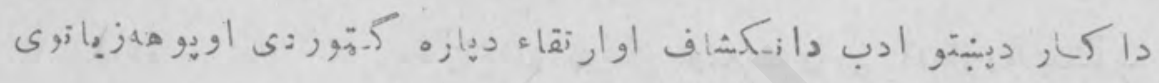

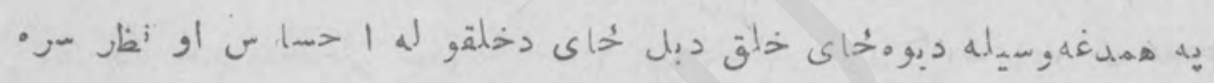

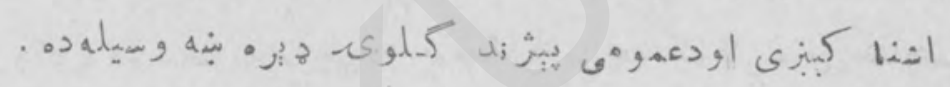

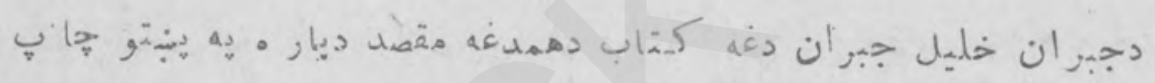
.

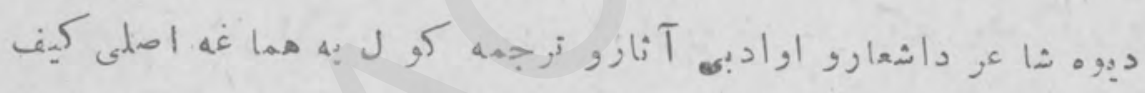

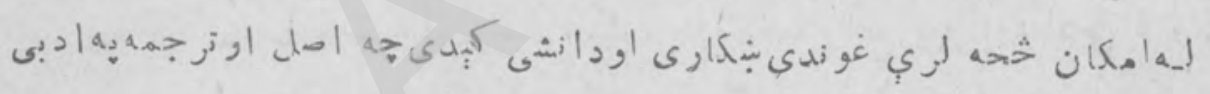

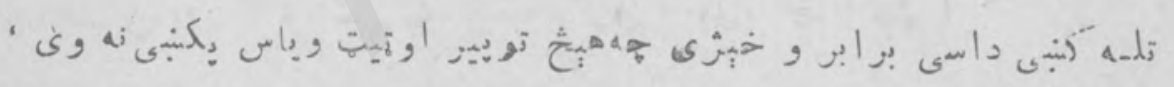

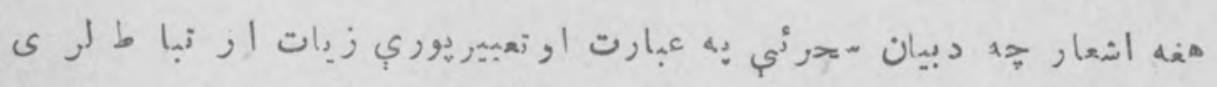

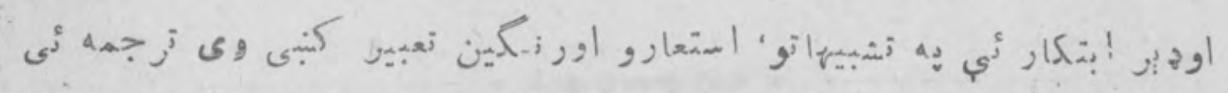

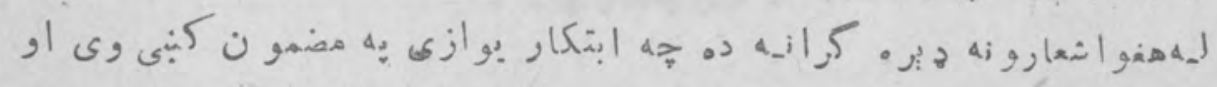

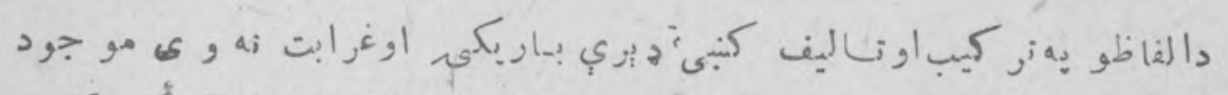

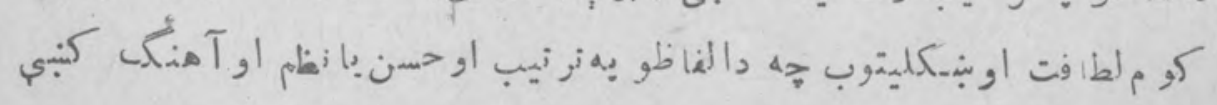


(ب)

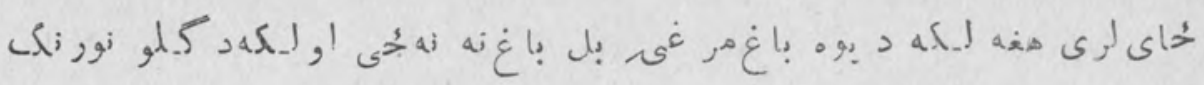

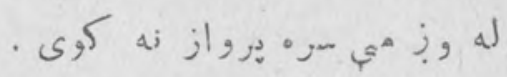

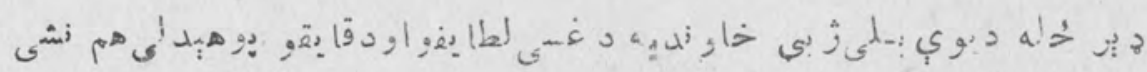

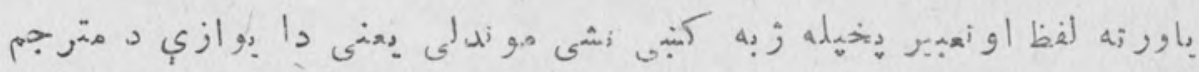

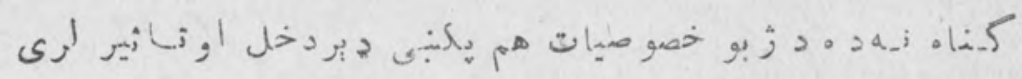
定

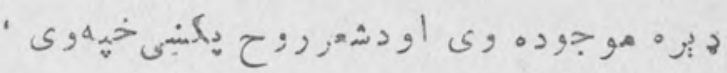

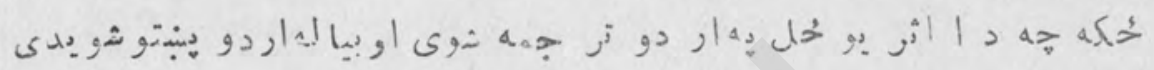

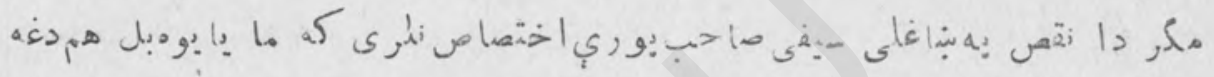

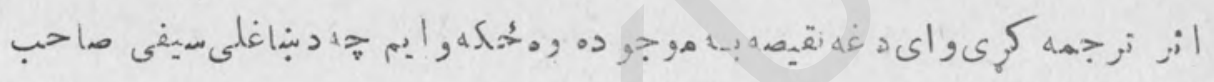

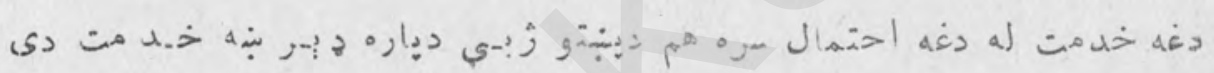

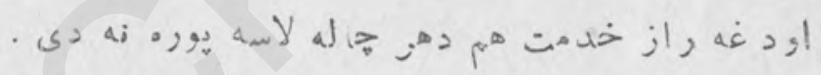

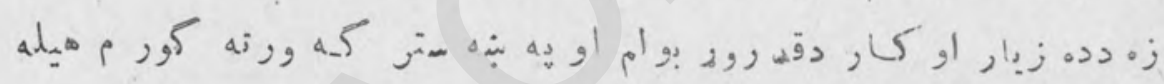

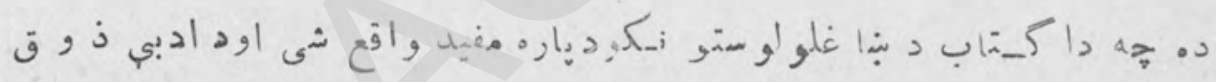
او احسا 


\section{! 2 S}

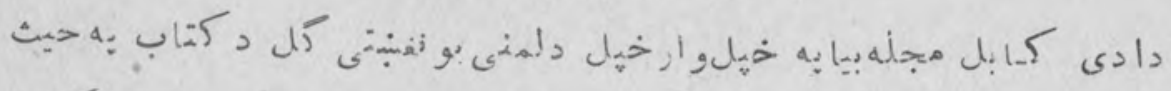

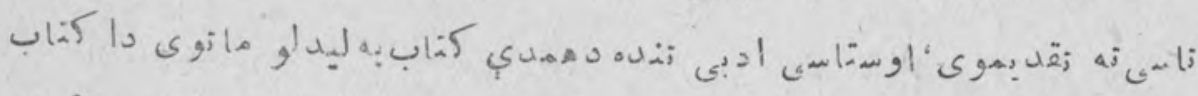

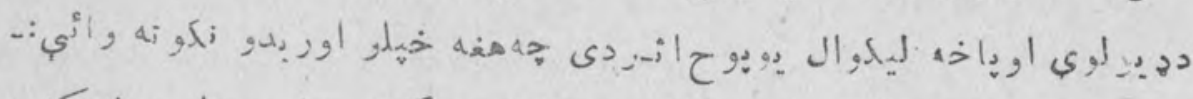

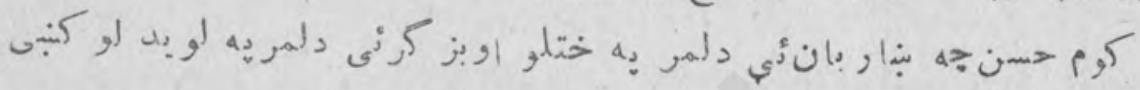

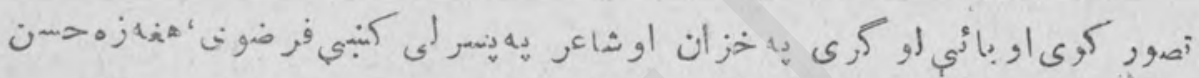

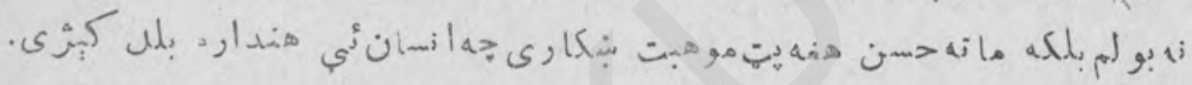

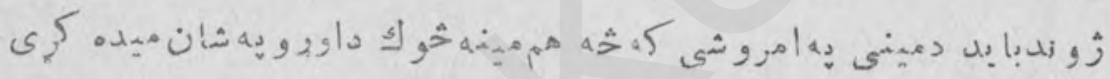

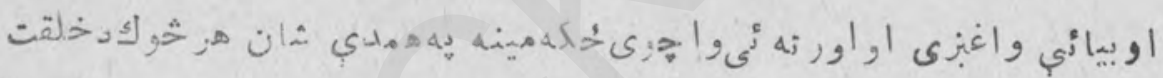

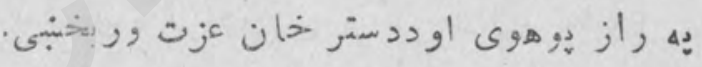

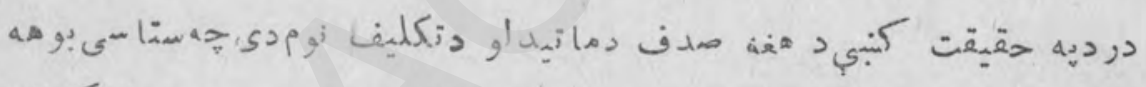

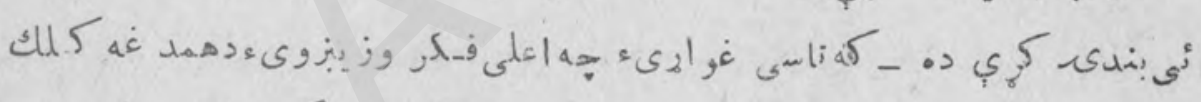

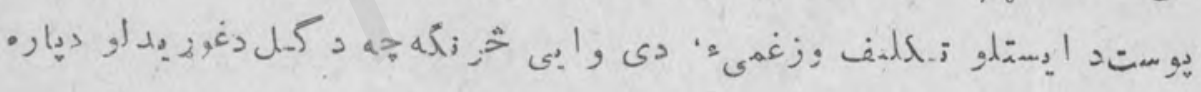

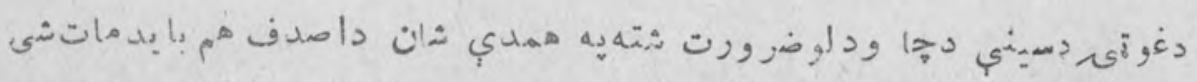

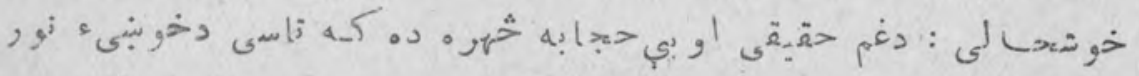

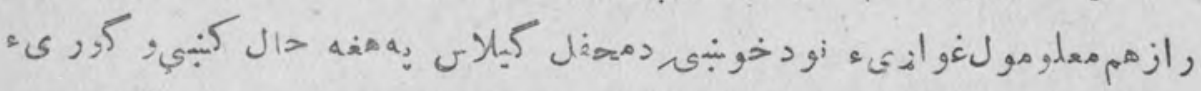

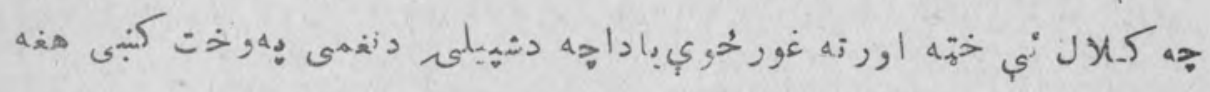

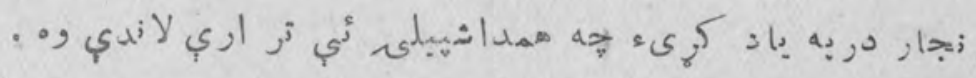

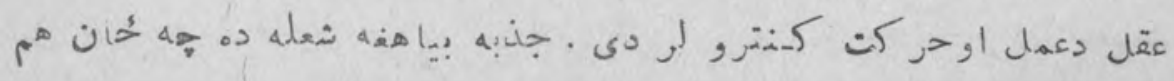

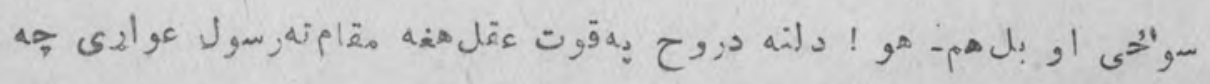




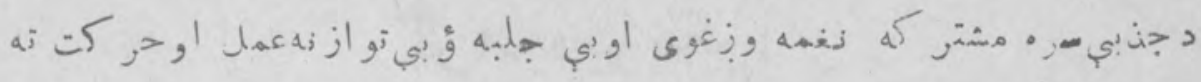

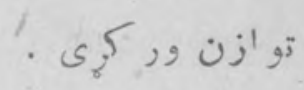

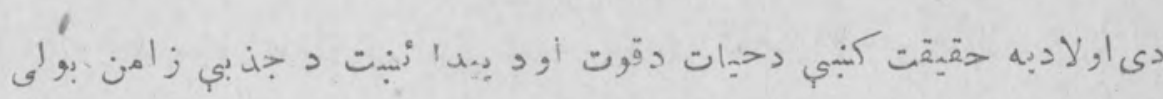

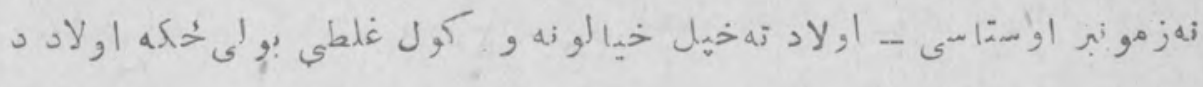

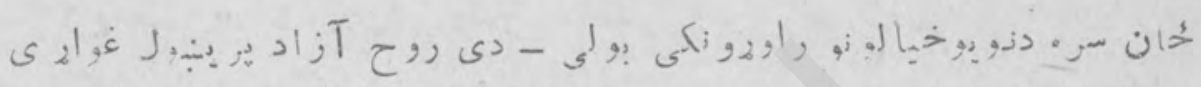

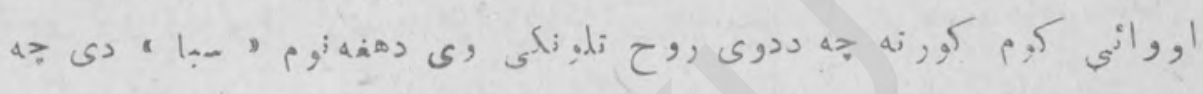
(i)

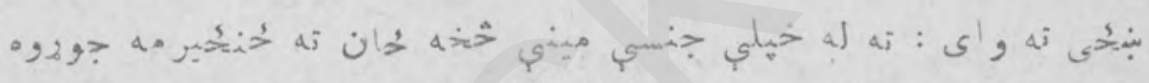

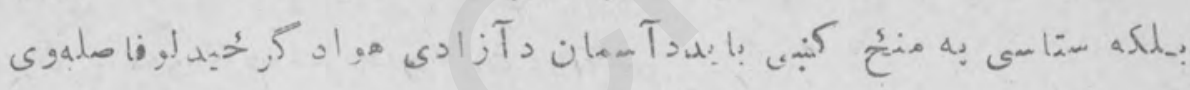

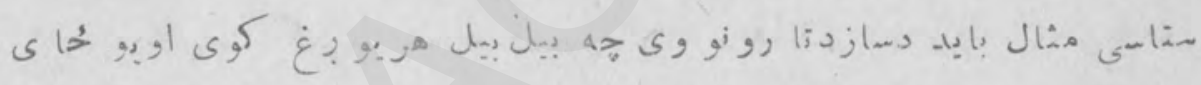

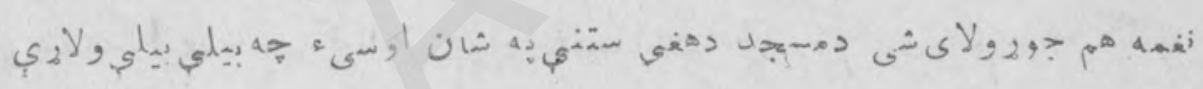

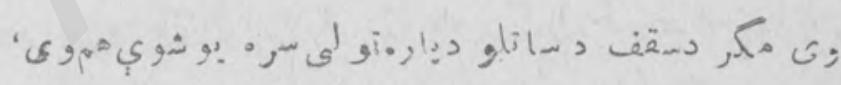

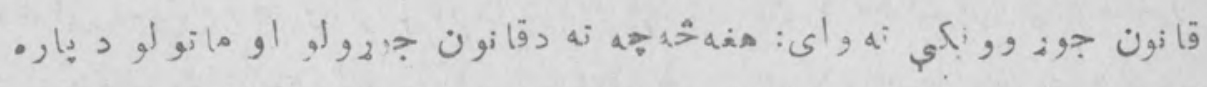

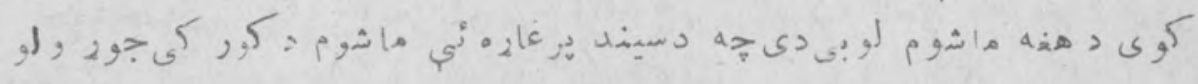

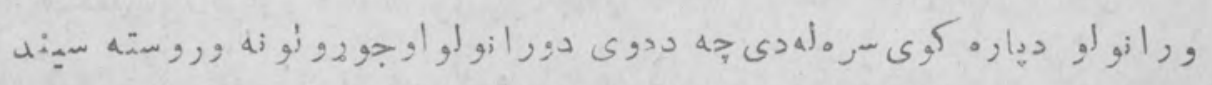

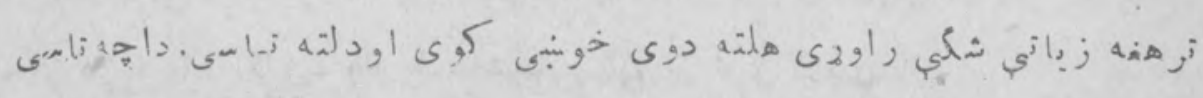

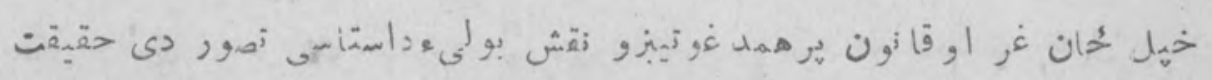

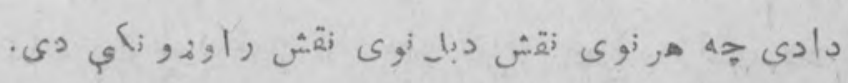




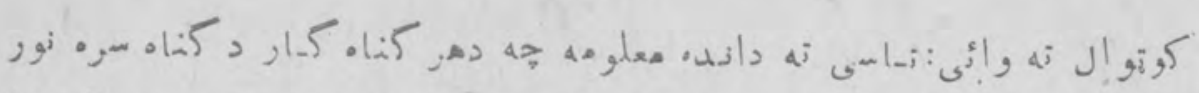

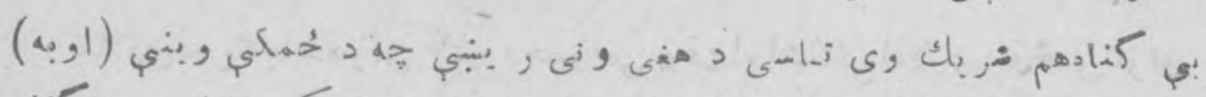

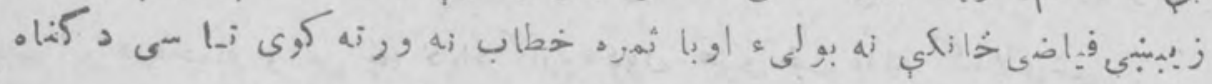

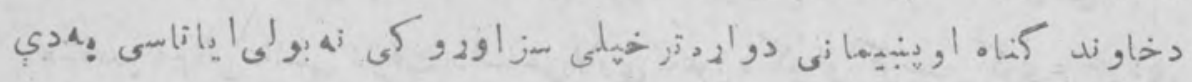

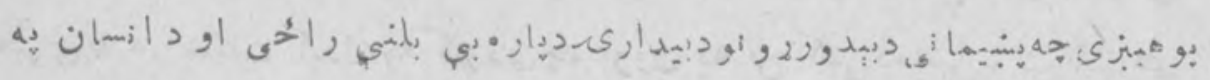

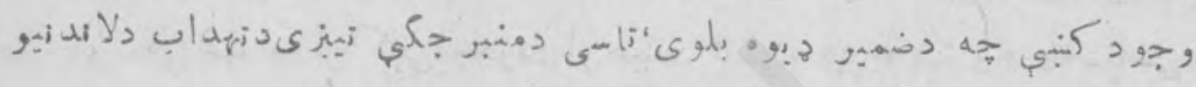

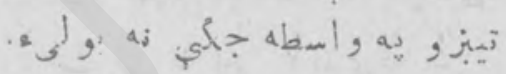

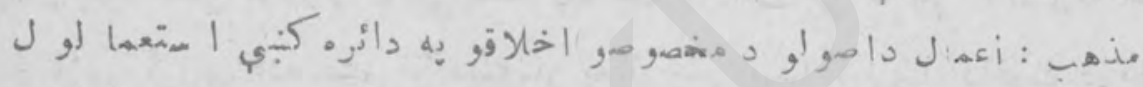

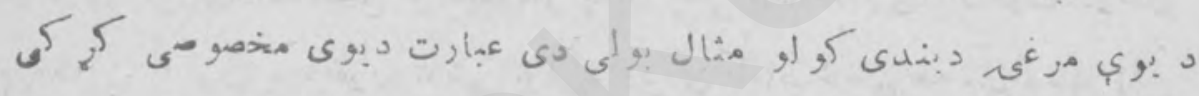

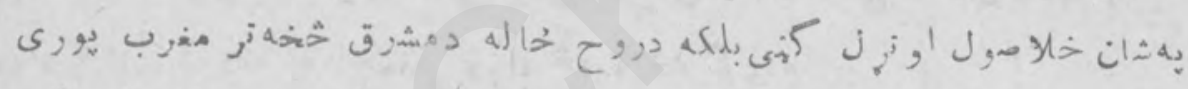

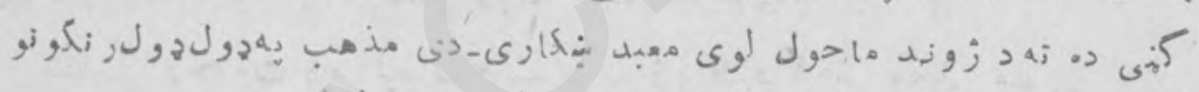

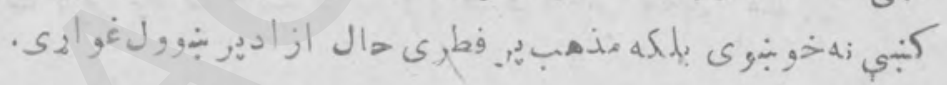

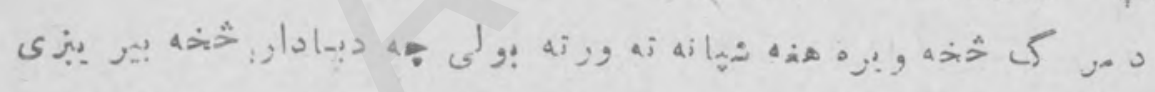

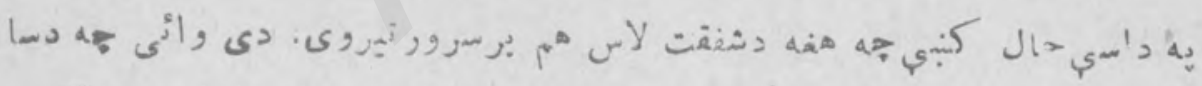

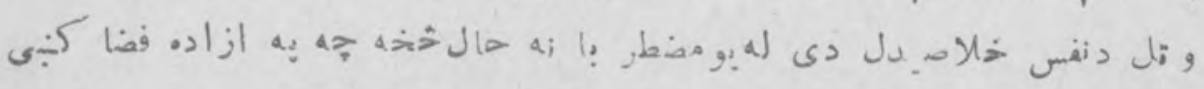

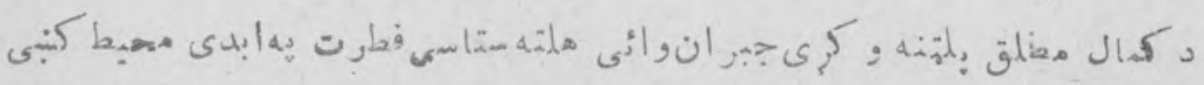

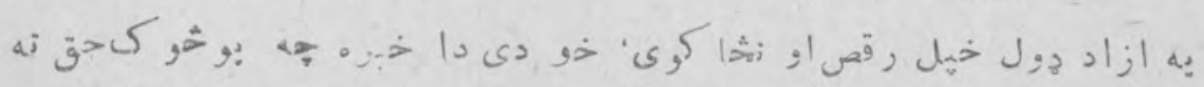

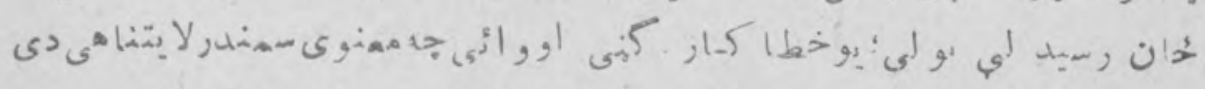

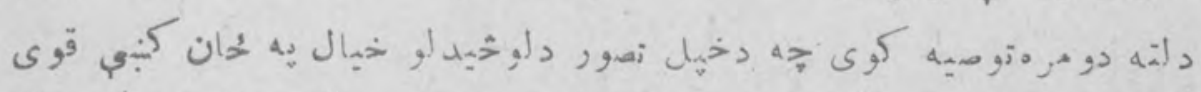

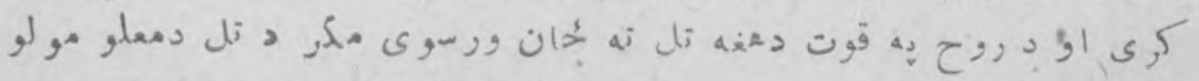

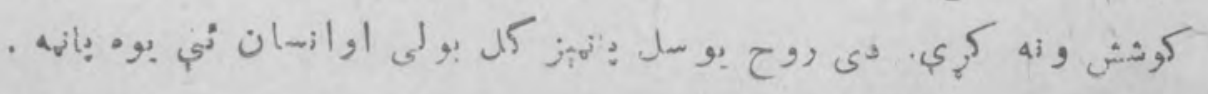




\section{'g)}

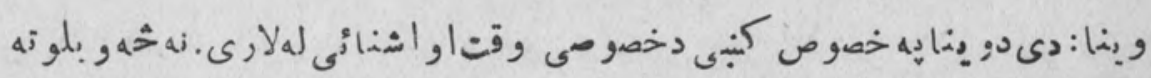

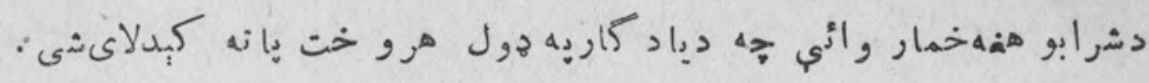

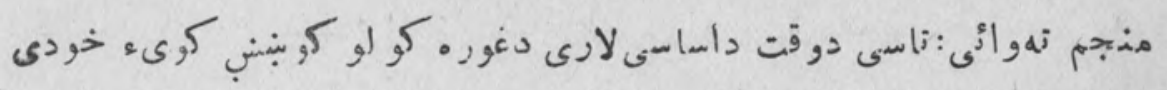

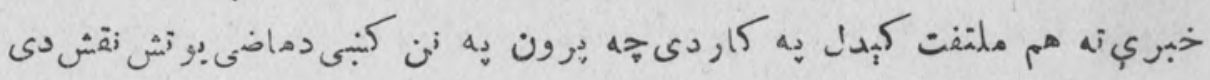

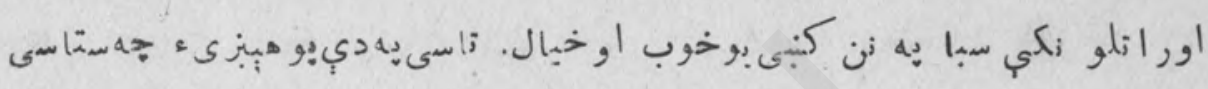

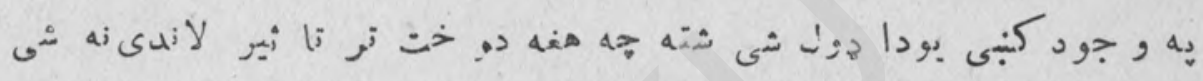

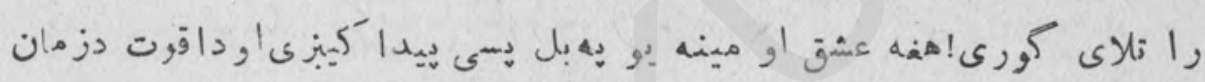

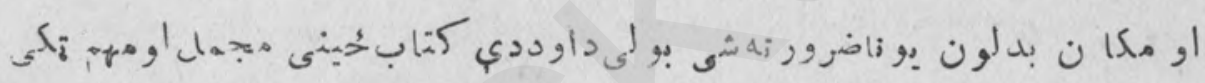

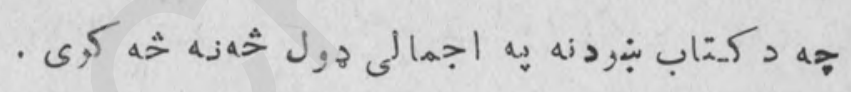

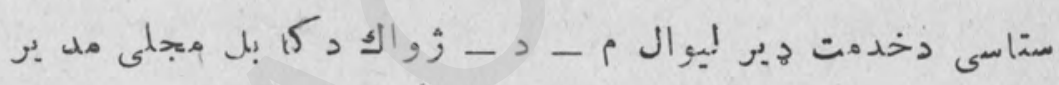




\section{is}

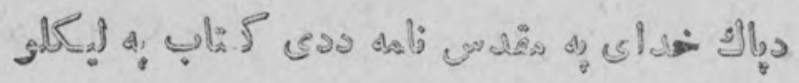

$$
\text { (1) } 1 \text { (1) } \log ^{3}
$$

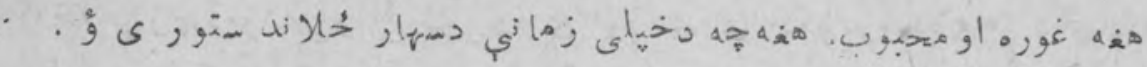

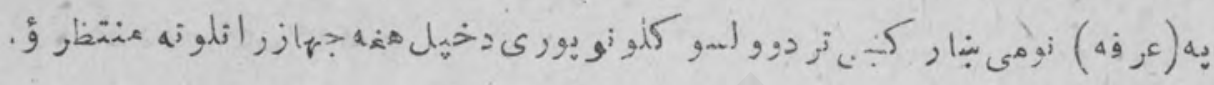

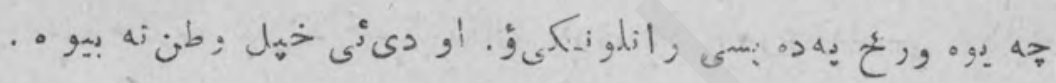

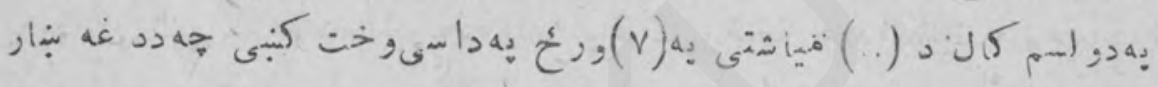

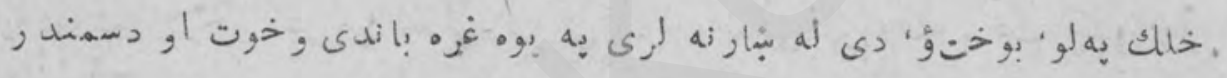

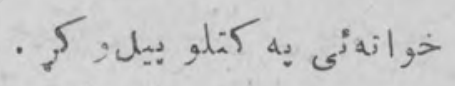

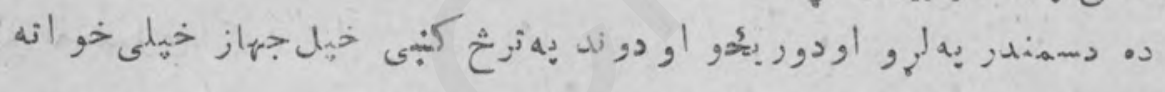

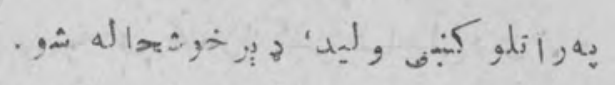

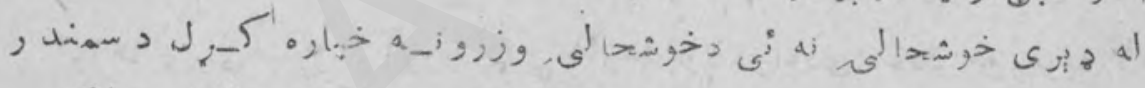

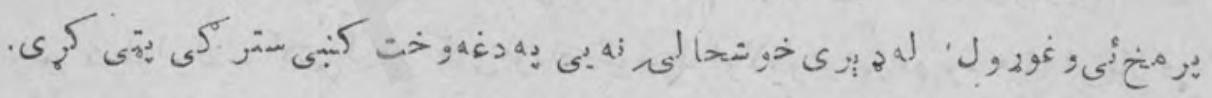
-

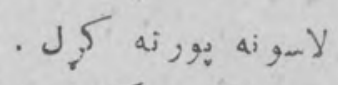

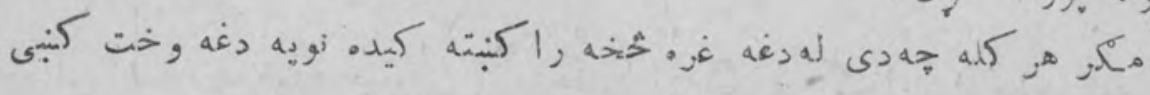

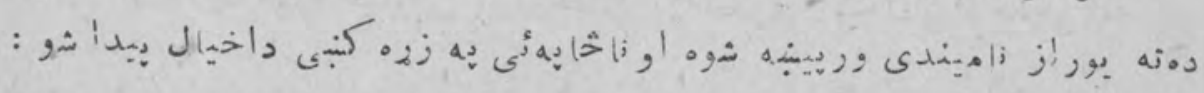

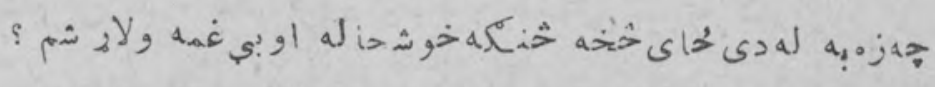

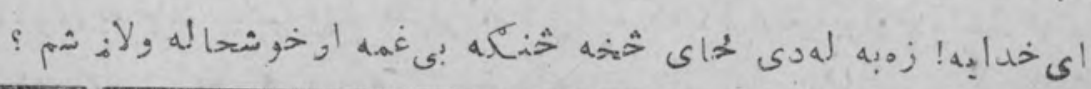

اودا جمال

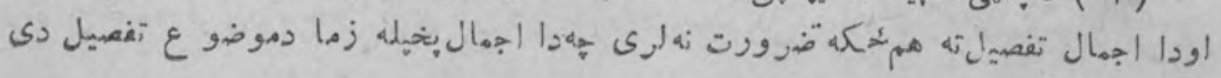




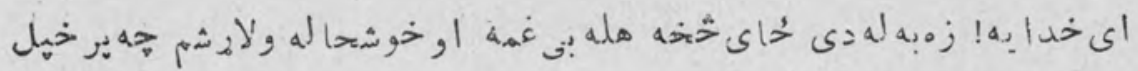

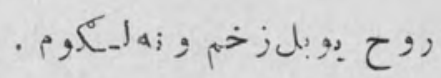

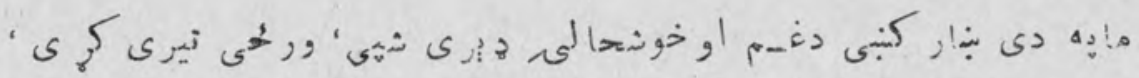

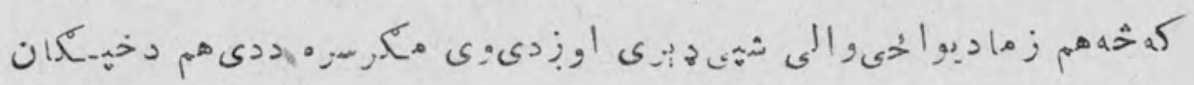

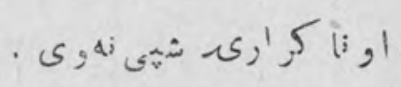

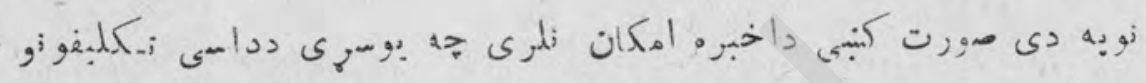

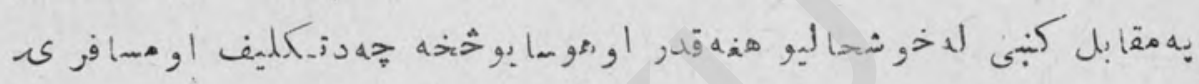

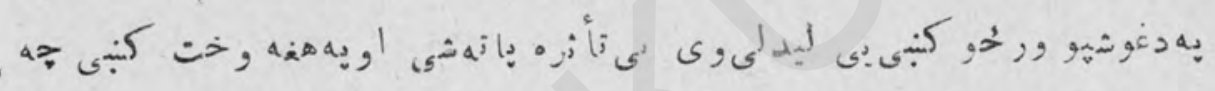
لو له s.

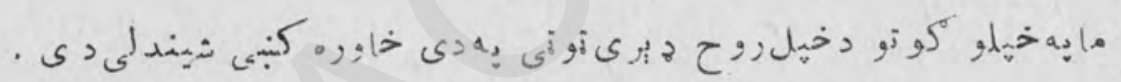

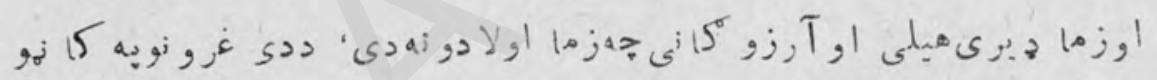

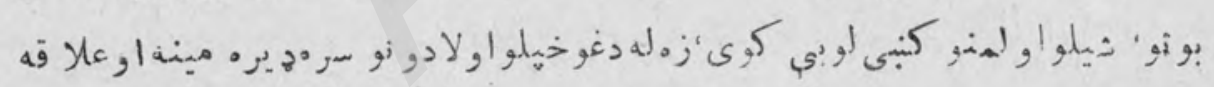

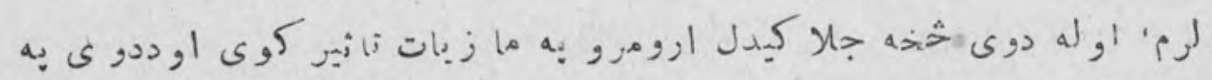

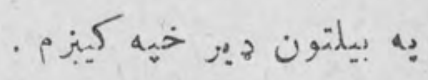

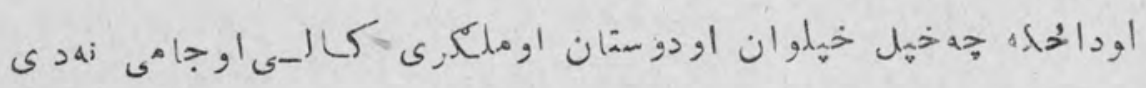

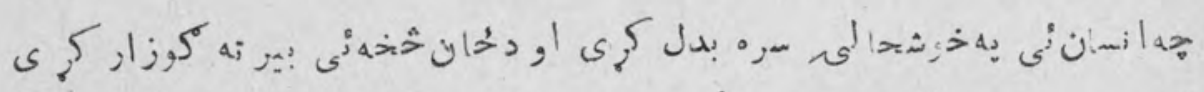

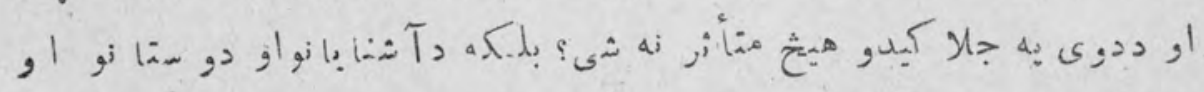

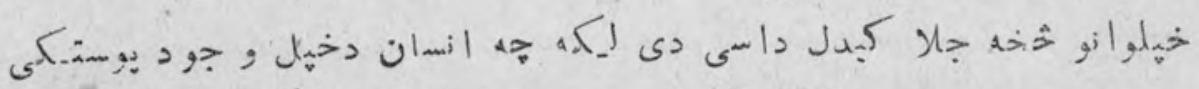

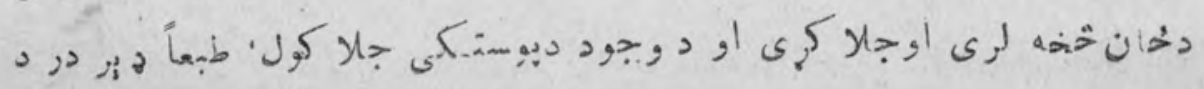




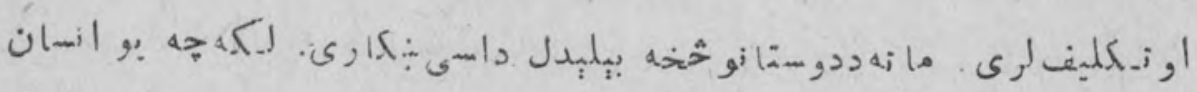

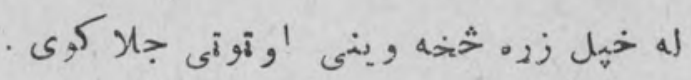

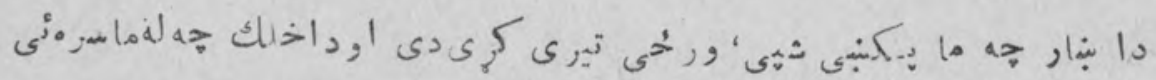

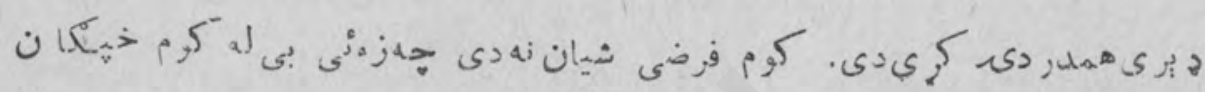

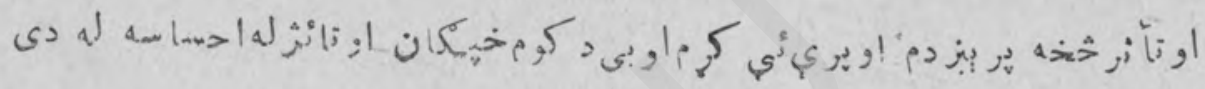
مإ

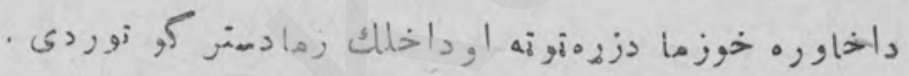

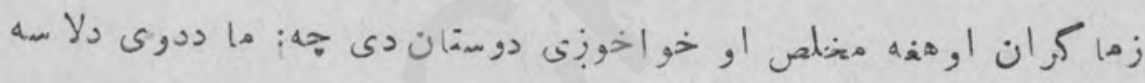

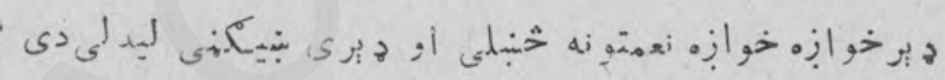

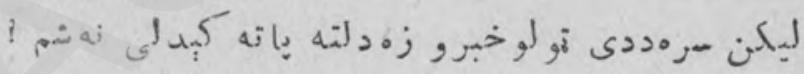

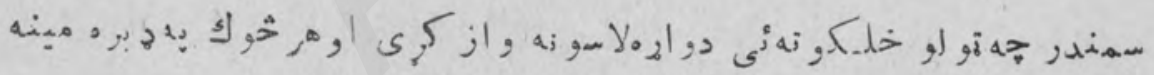

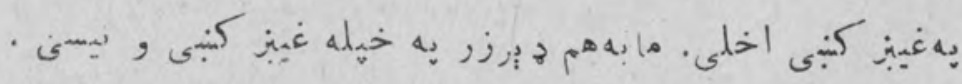

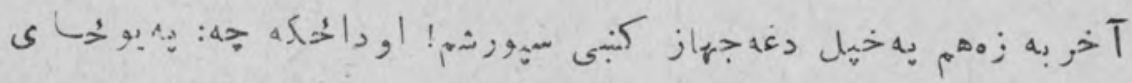

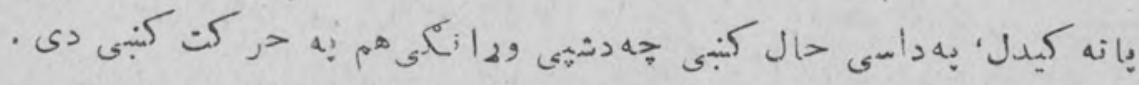

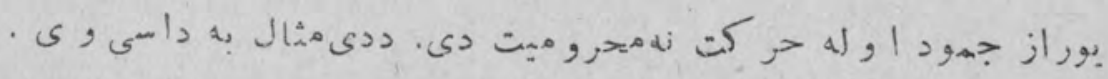

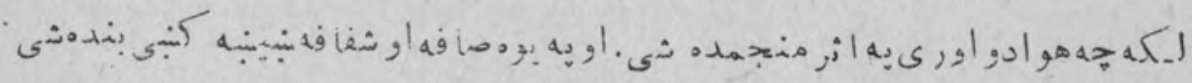

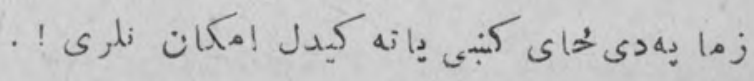

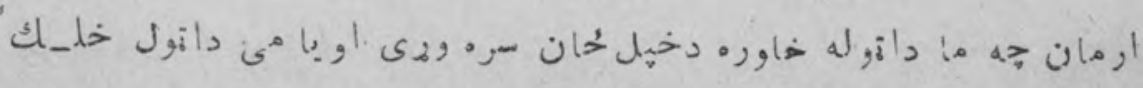

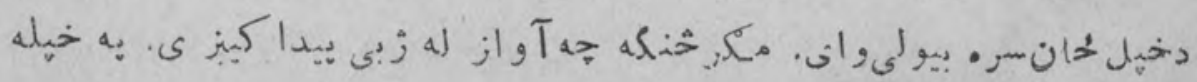




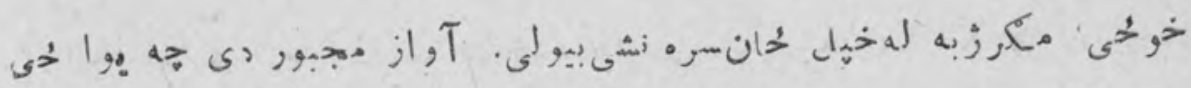

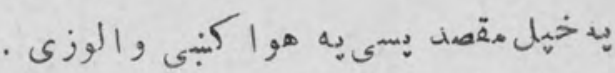

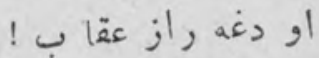

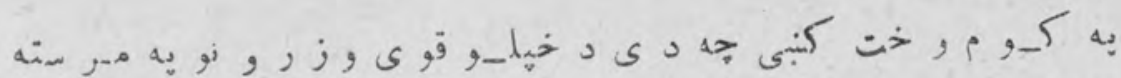

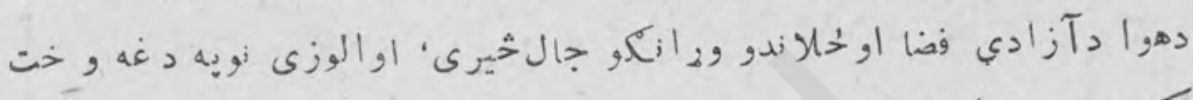

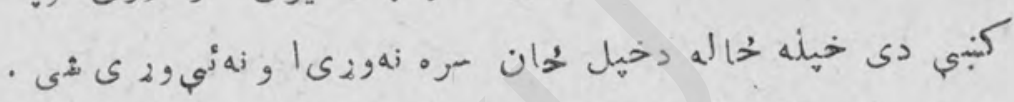

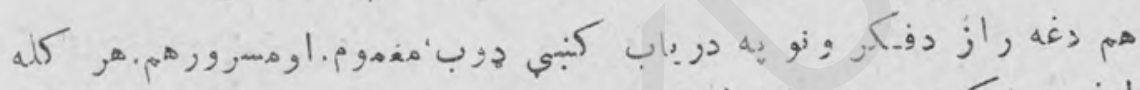

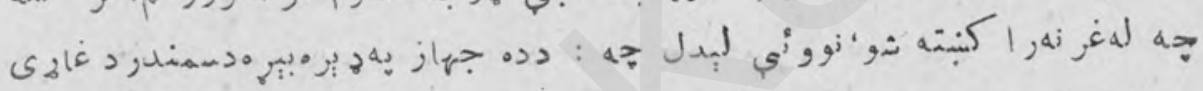

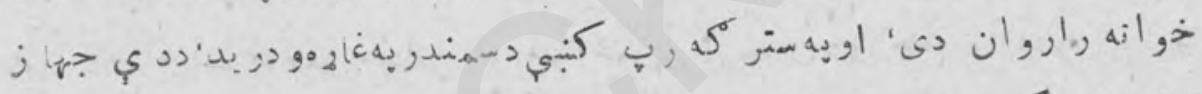

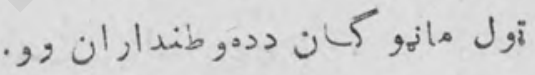

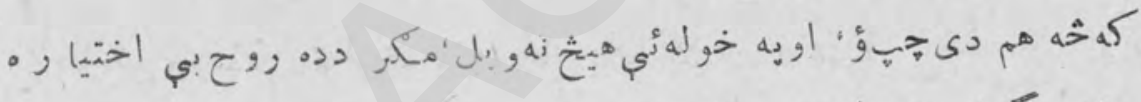

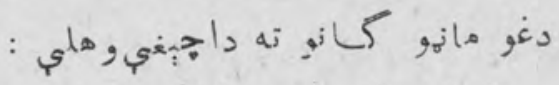

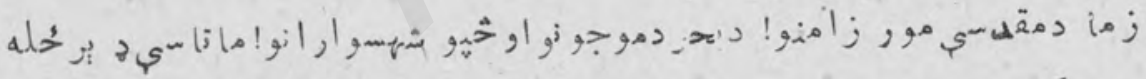

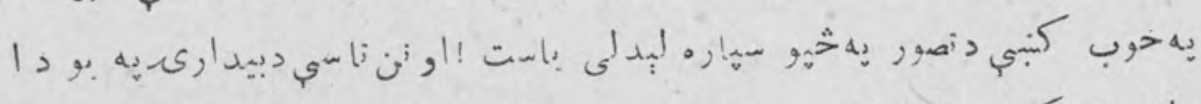

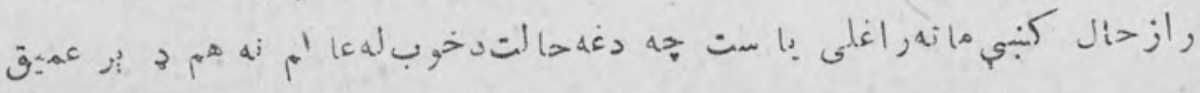

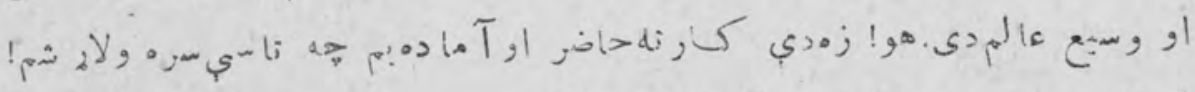

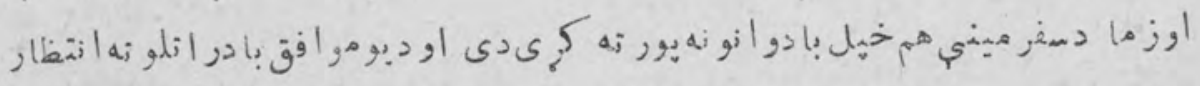
باسى.

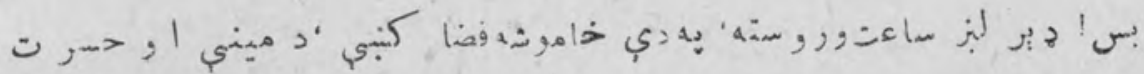

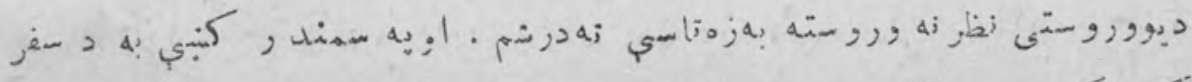

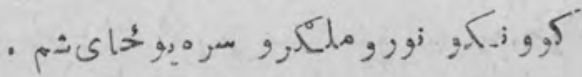




\section{(०)}

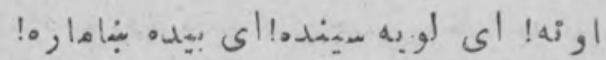

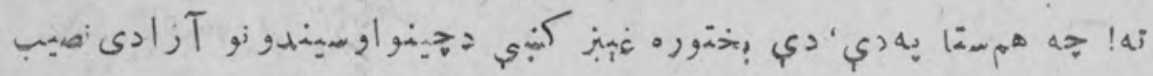

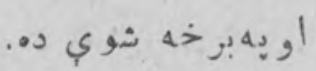

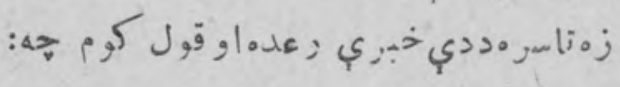

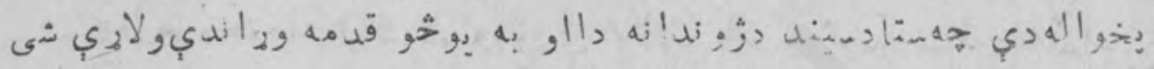

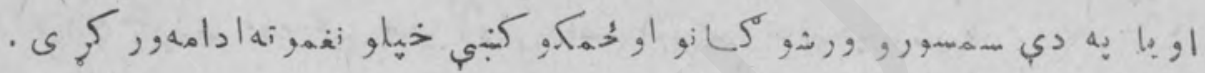

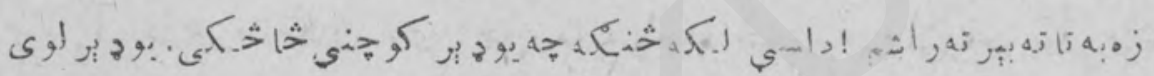

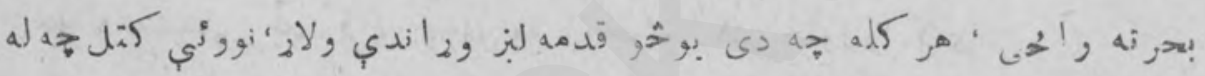

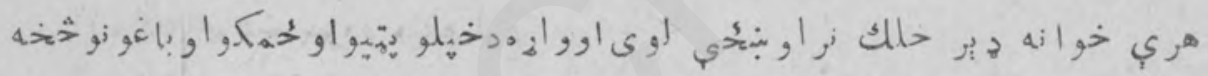

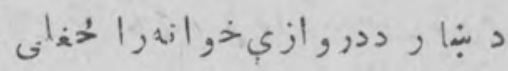

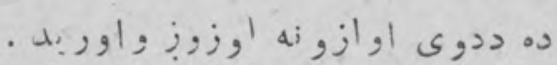

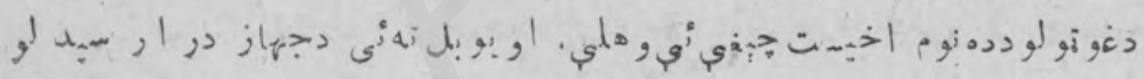

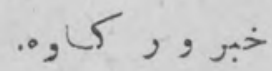

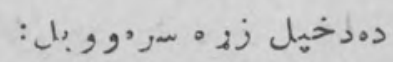

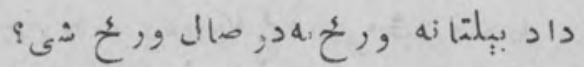

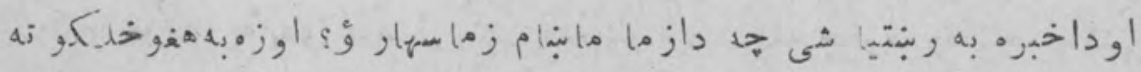

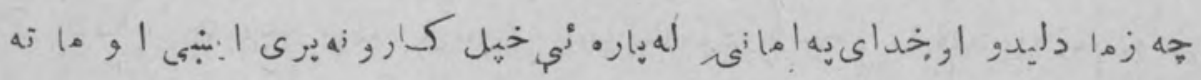

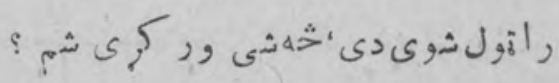

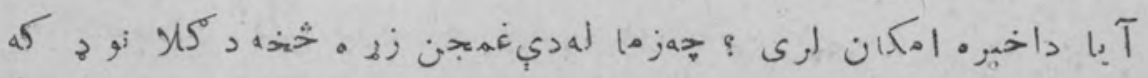

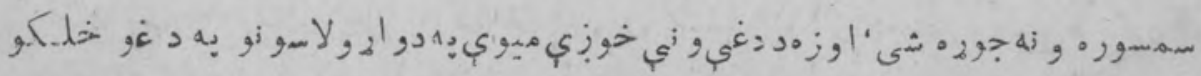




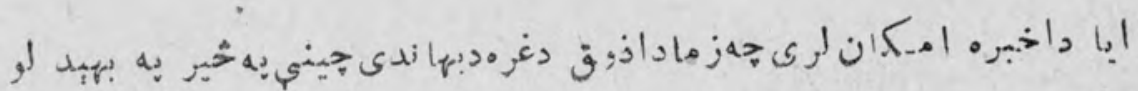

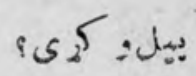

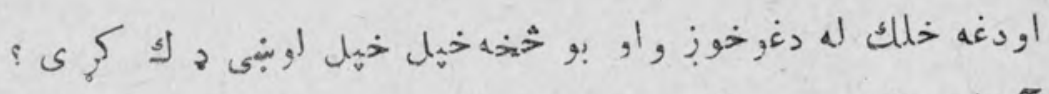

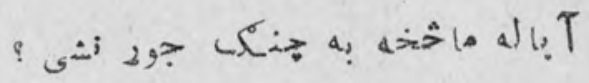

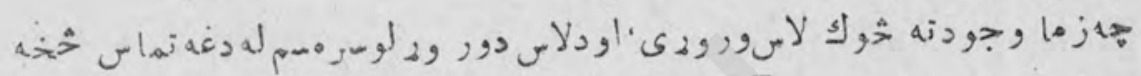

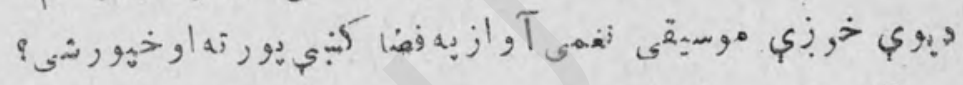

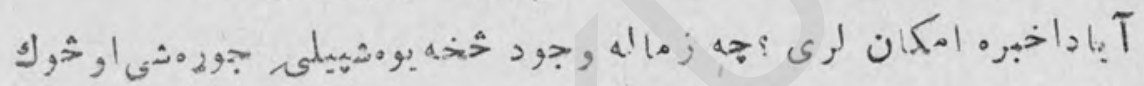

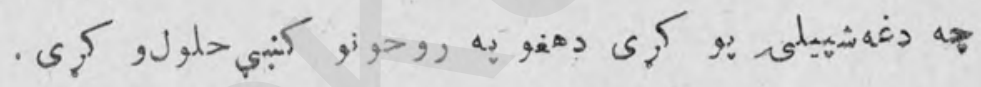

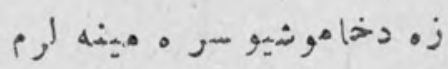

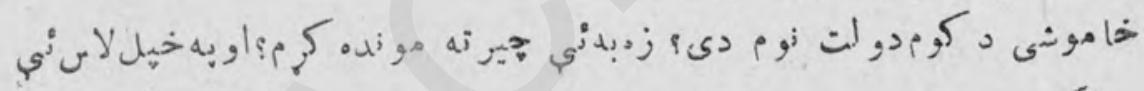

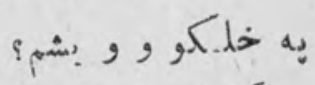

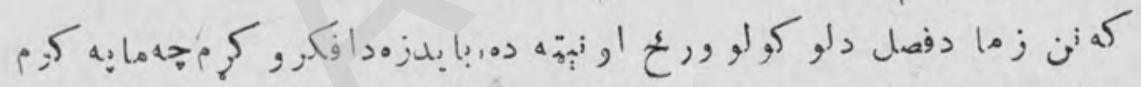

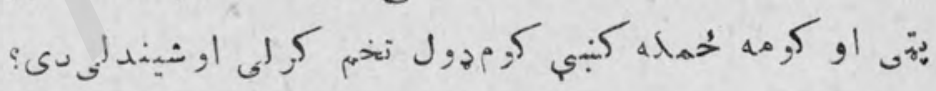

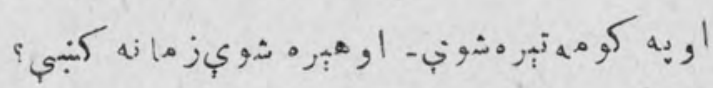

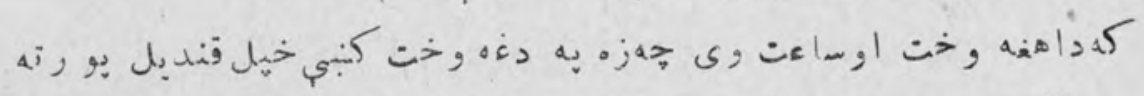

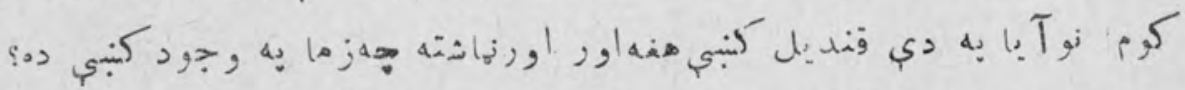

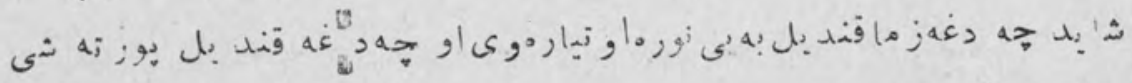

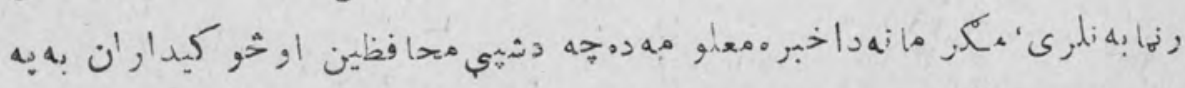

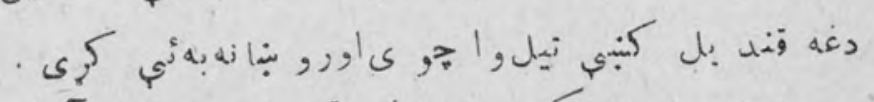

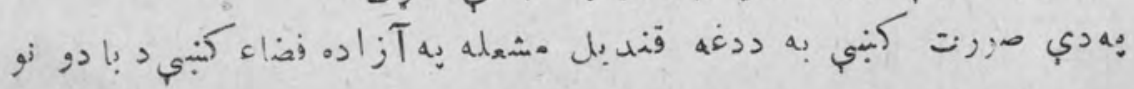

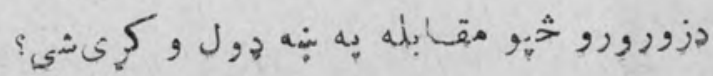




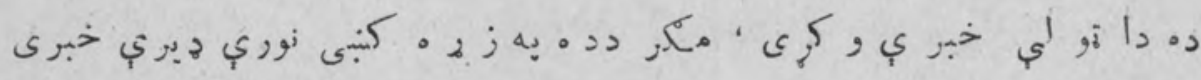

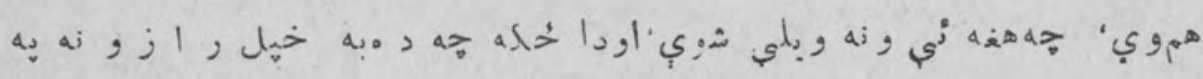

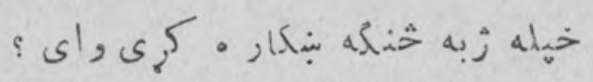

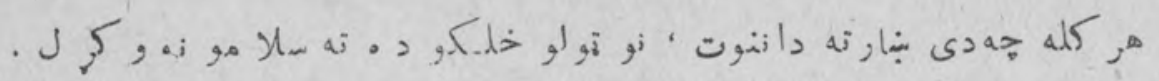

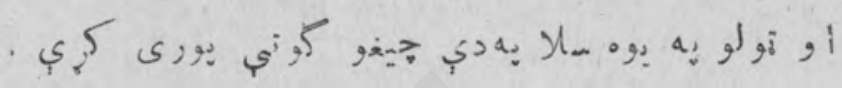

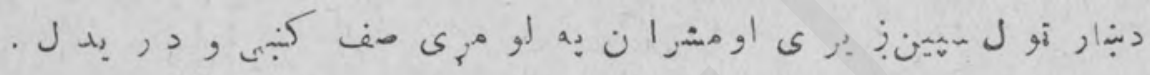

دوى بوبل :

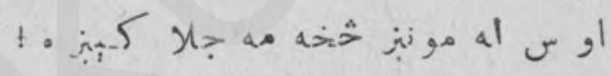

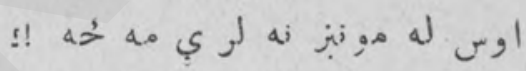

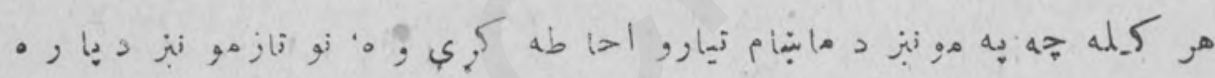

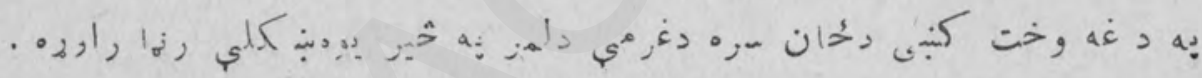

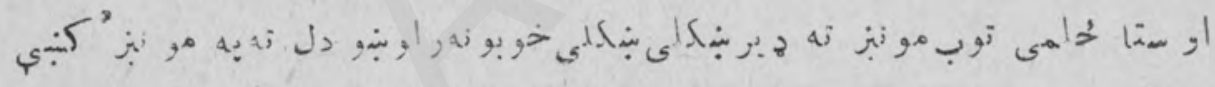

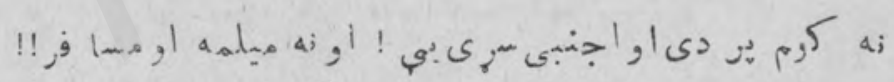

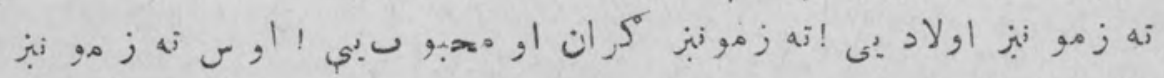

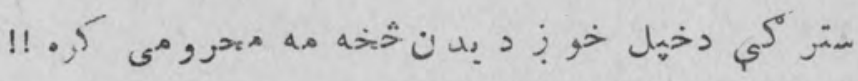

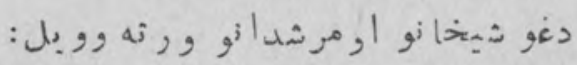

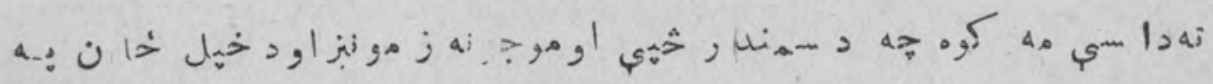

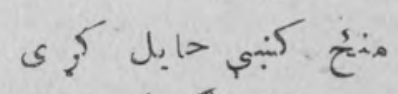

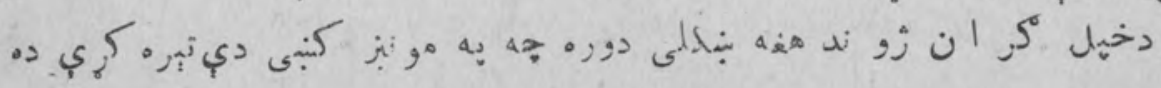

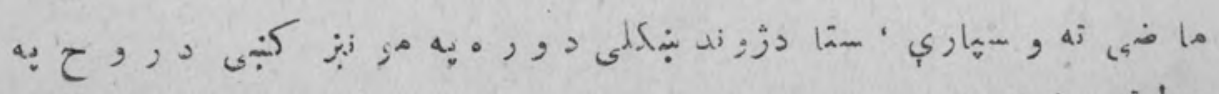
مولنبره شوي دماري 


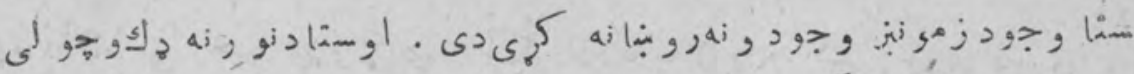

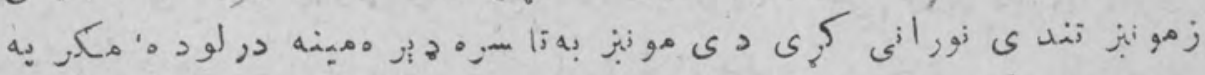

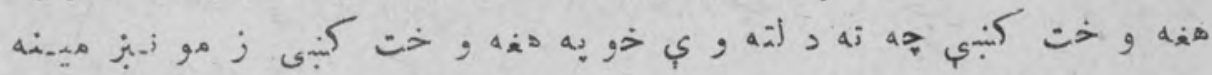

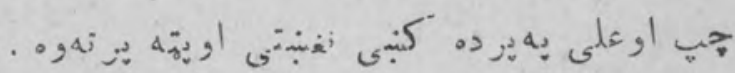

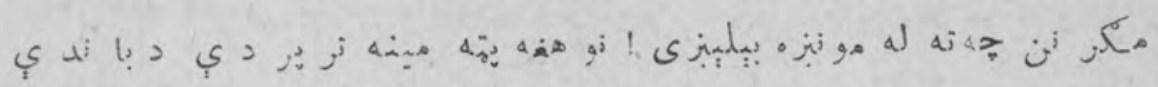

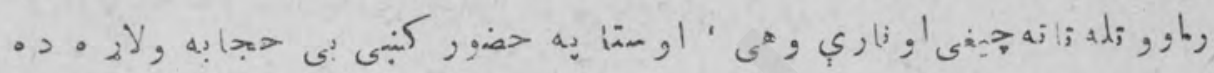

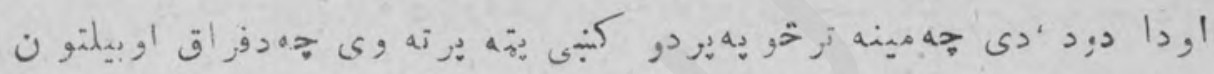

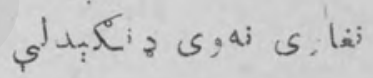

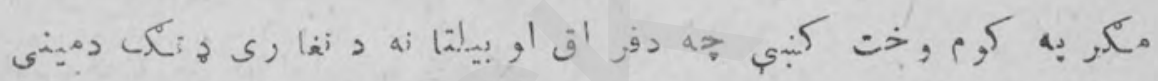

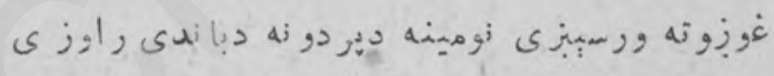
$-P$ -

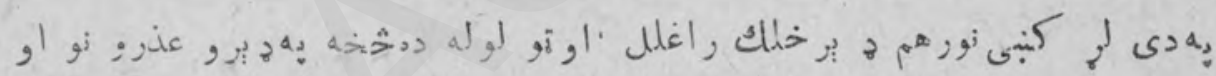

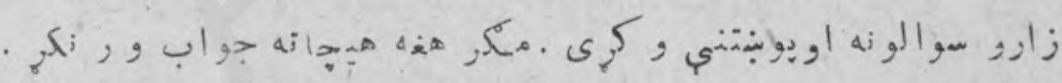

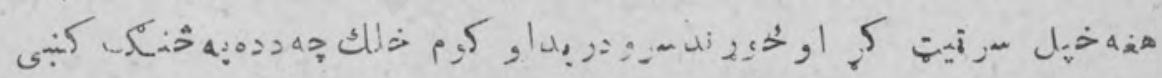
هil

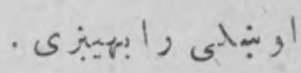

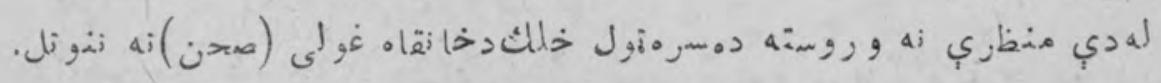

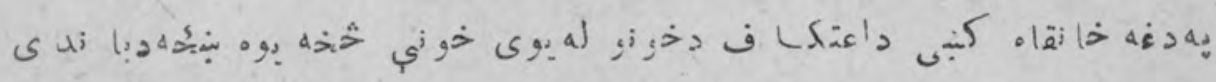

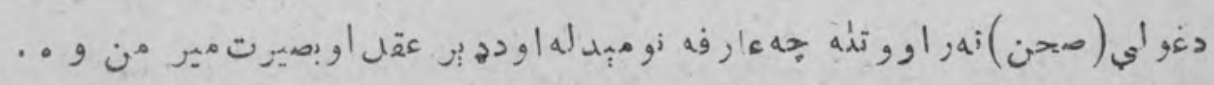

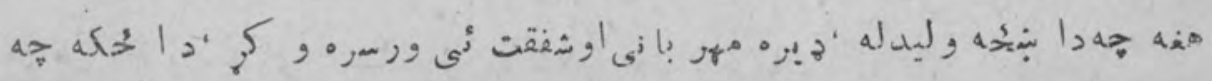

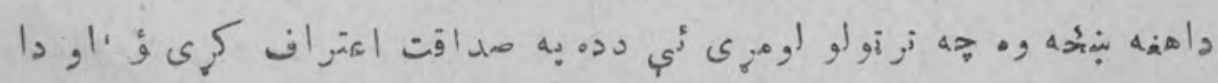




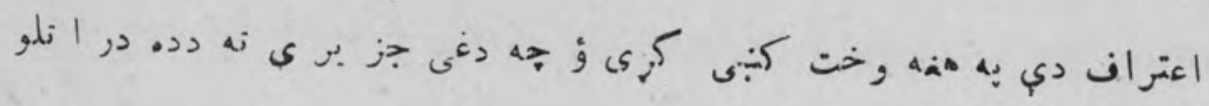
..., خ , د,

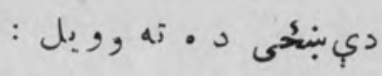

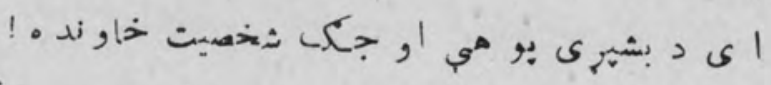

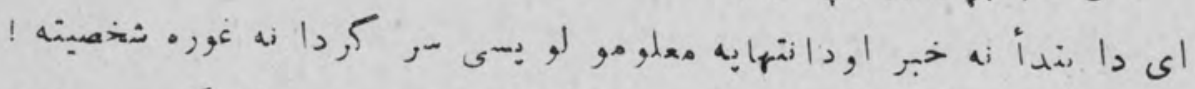

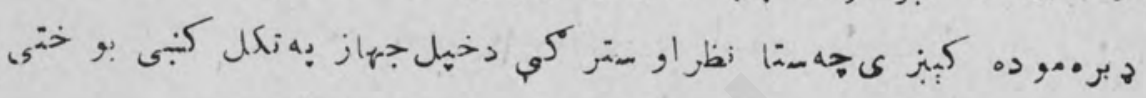

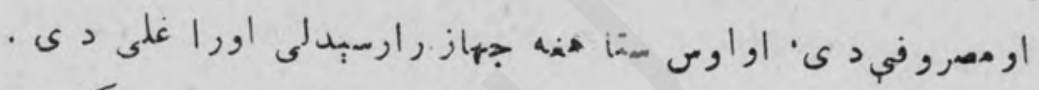

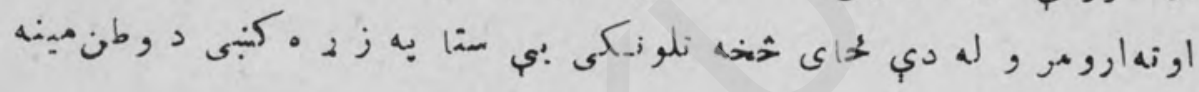

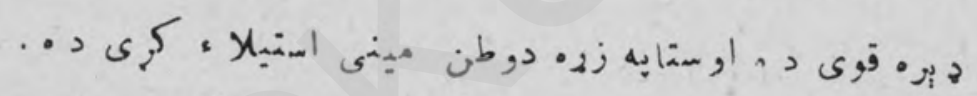

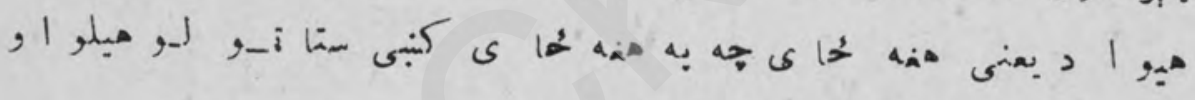

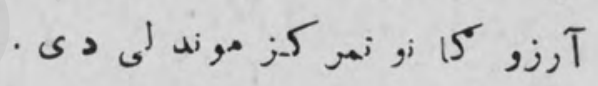

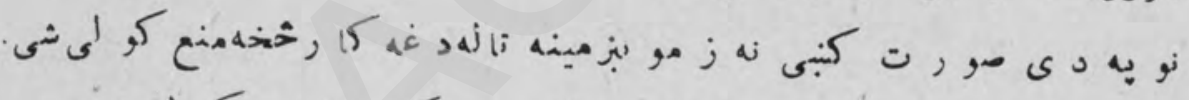

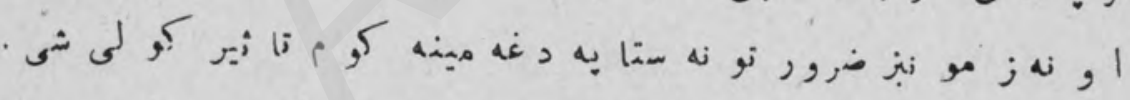

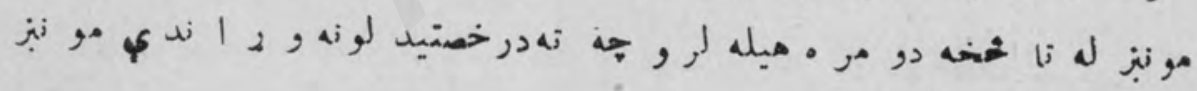

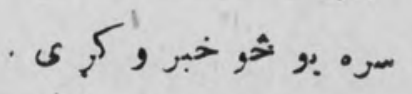

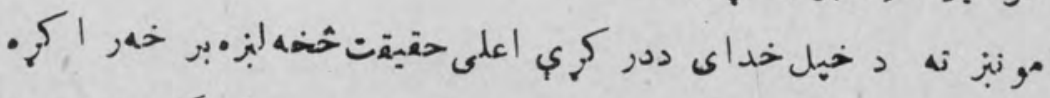

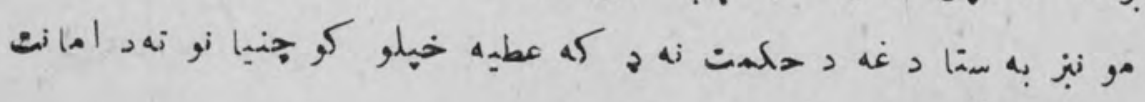

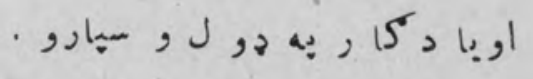

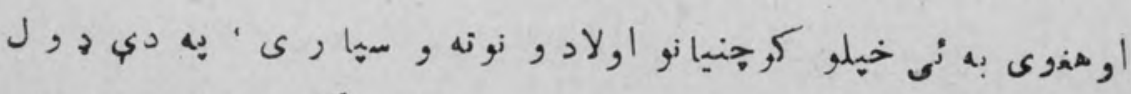

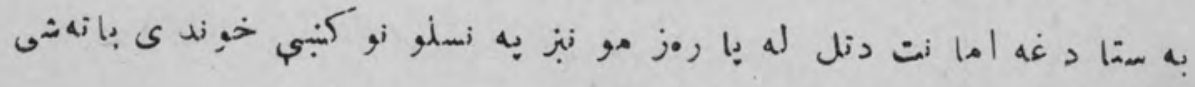




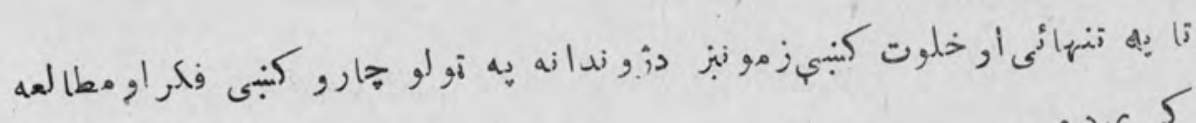
-

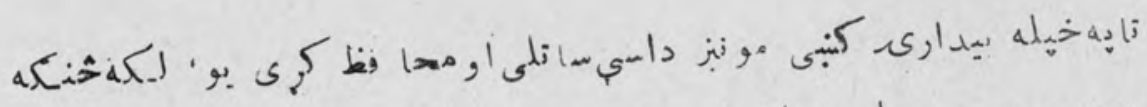

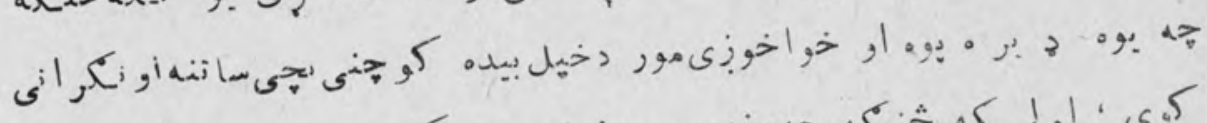

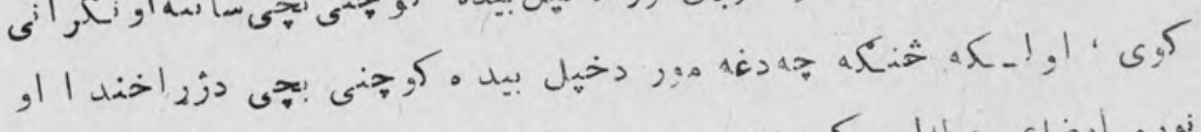

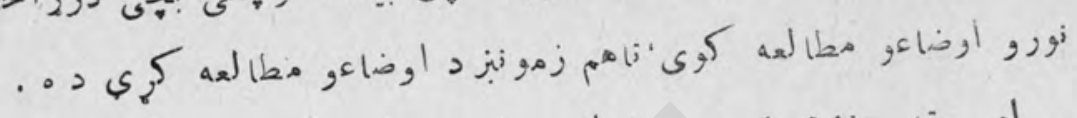

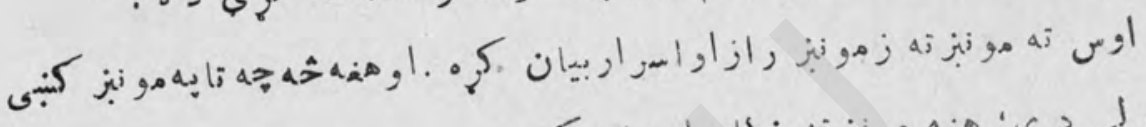

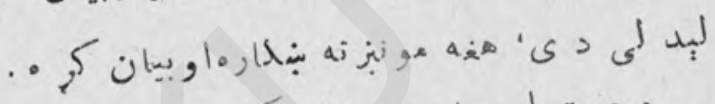

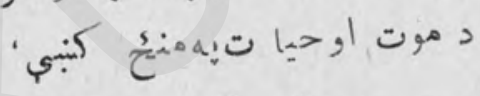

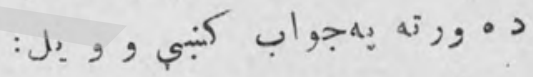

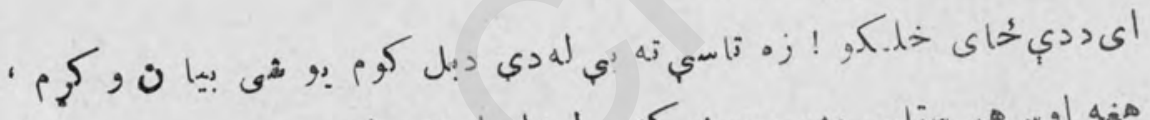

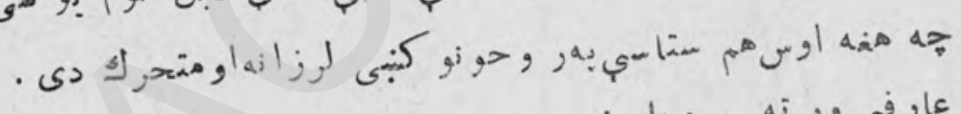

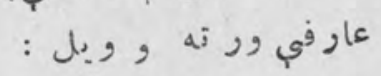

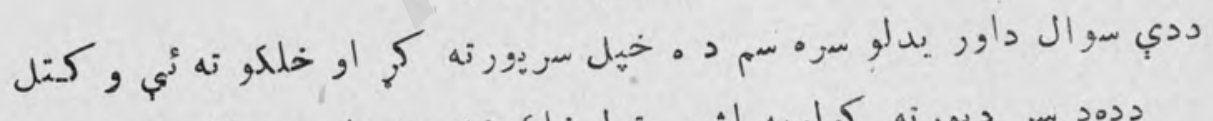

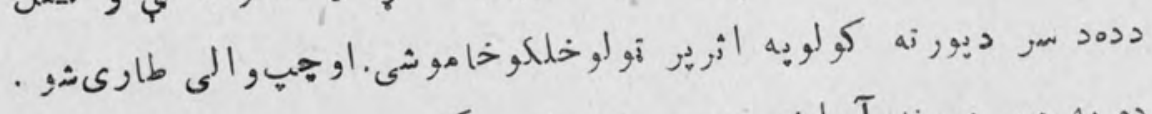

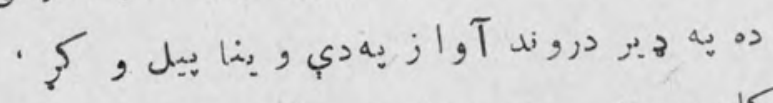

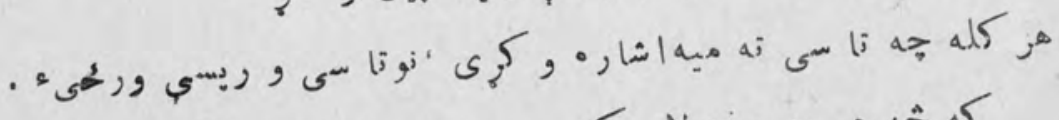

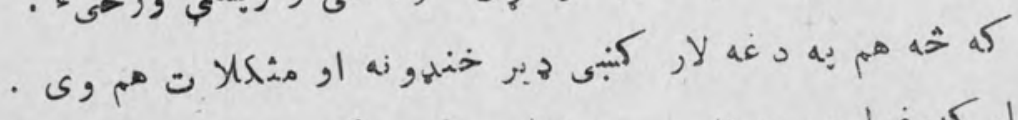

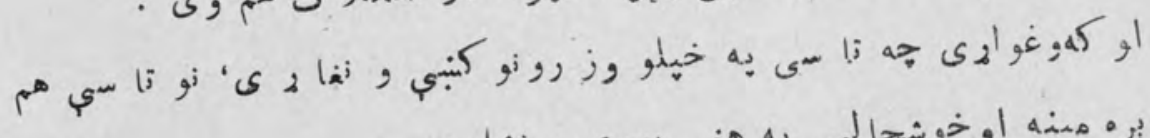

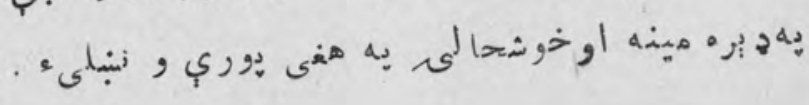




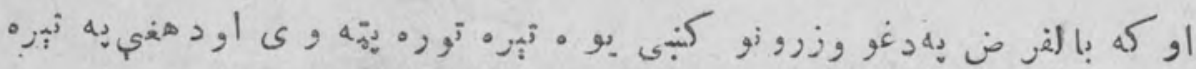

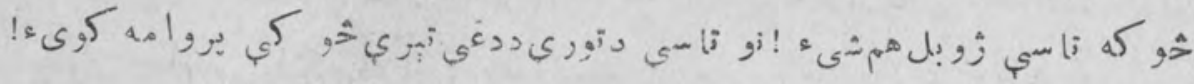

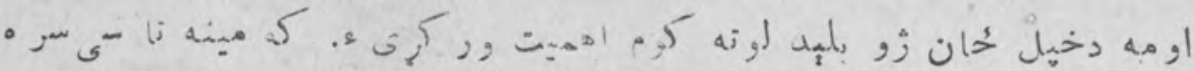

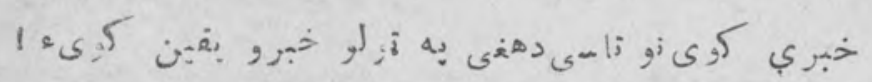

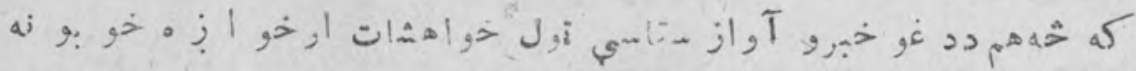

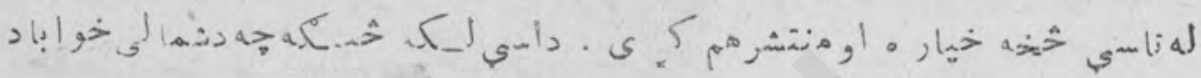

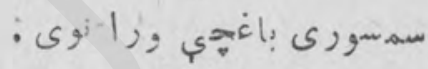

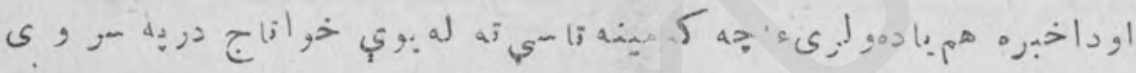

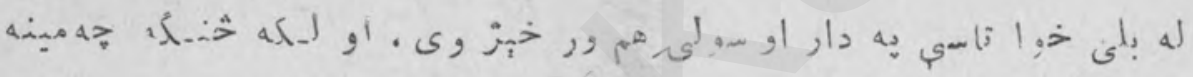

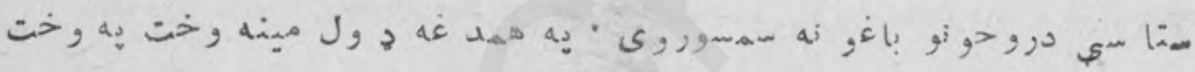

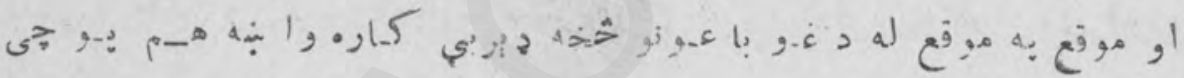
is 5 (ن)

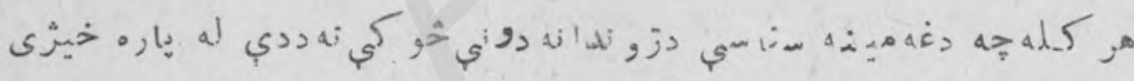

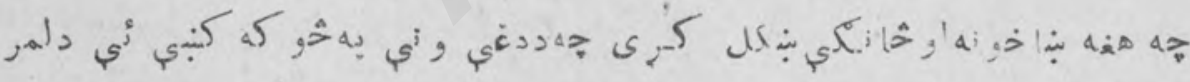

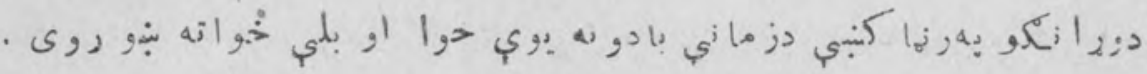

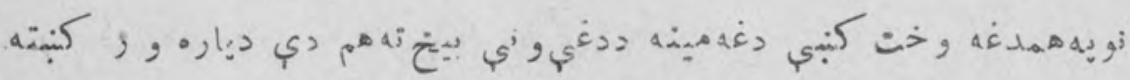

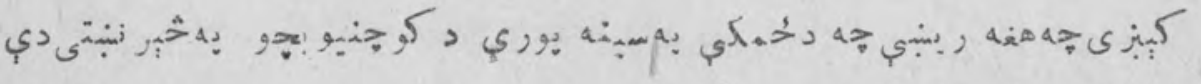
ل

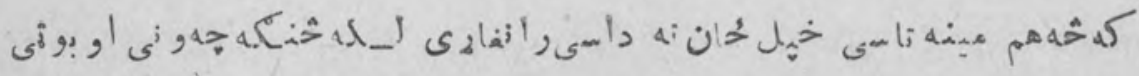

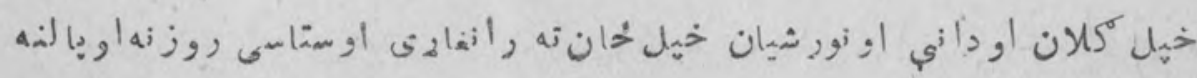




\section{$(1 r)$}

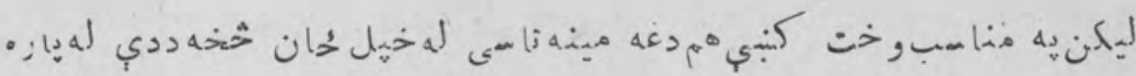

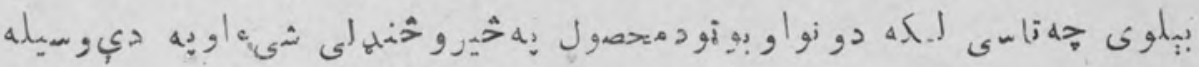

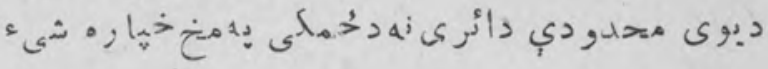

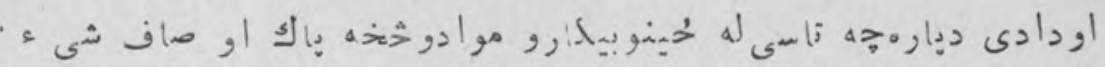

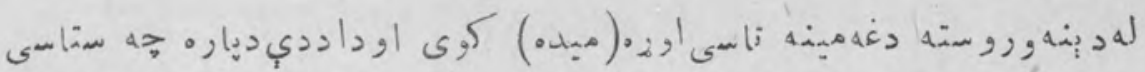

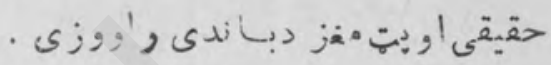

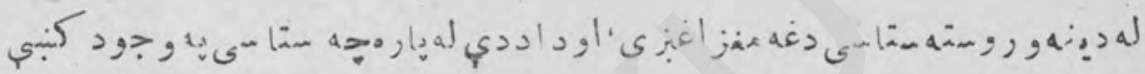

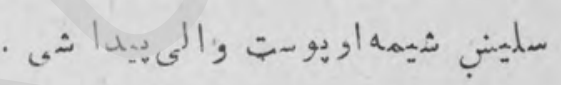

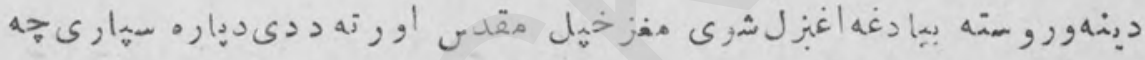

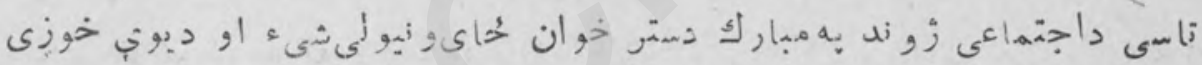

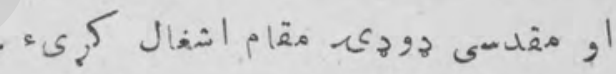

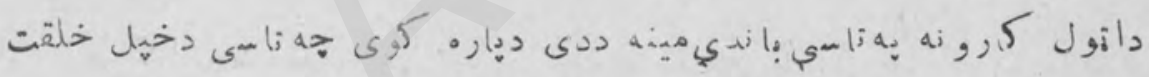

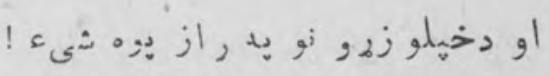

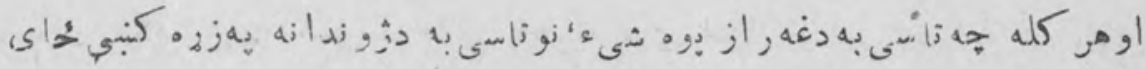

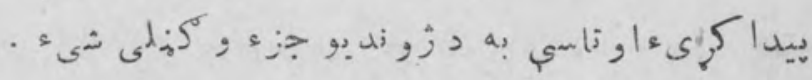

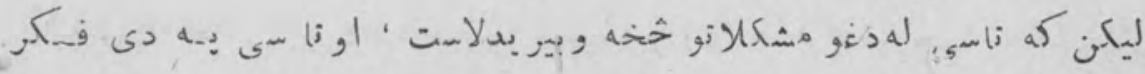

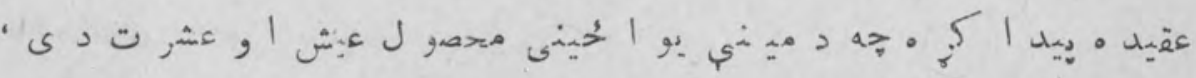

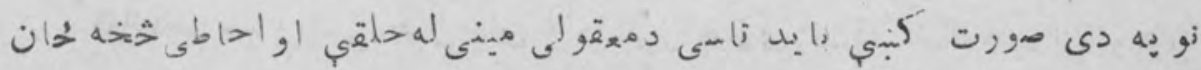

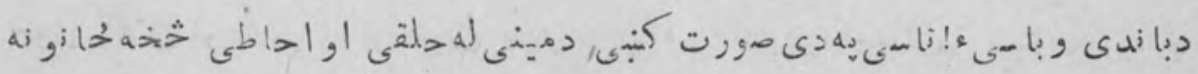

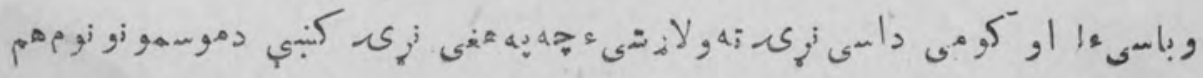




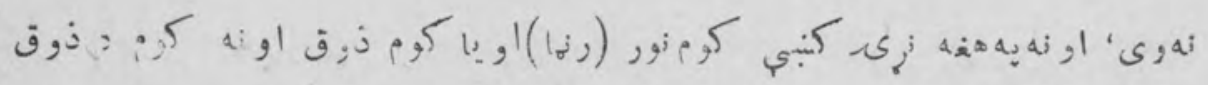

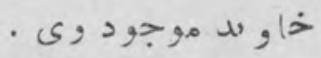

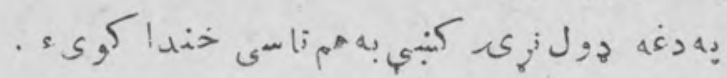

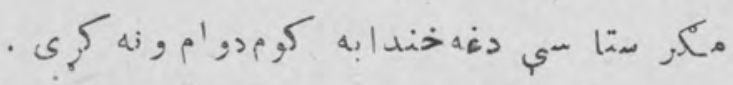

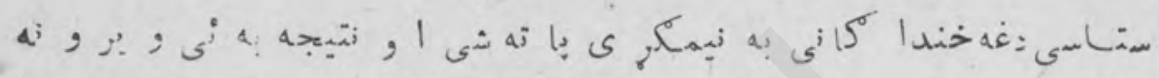
- 1

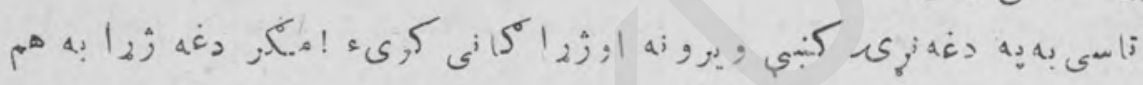

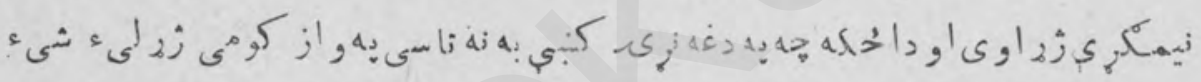

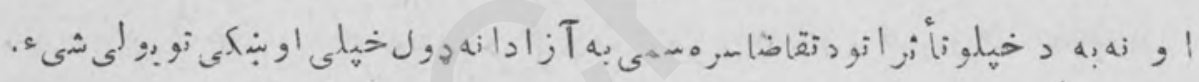

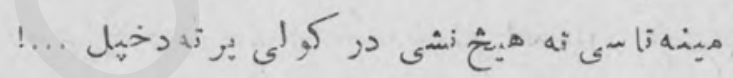

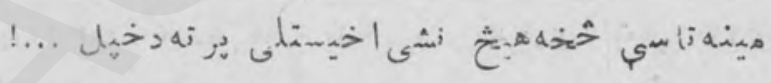

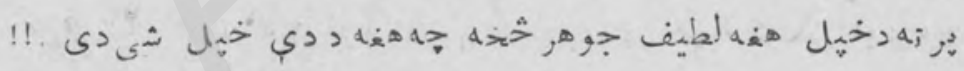

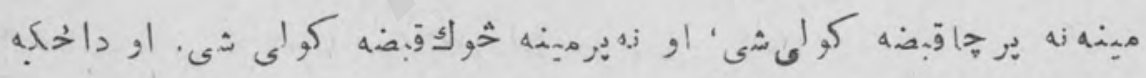

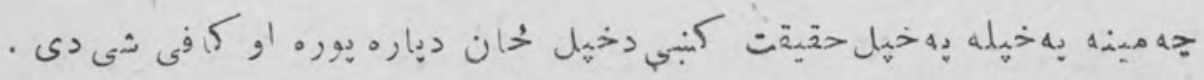

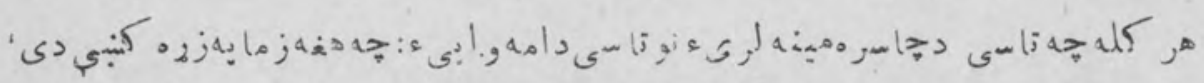

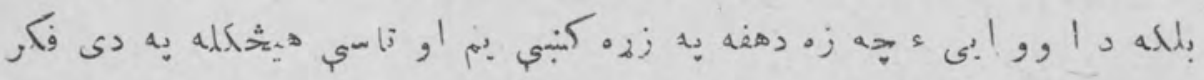

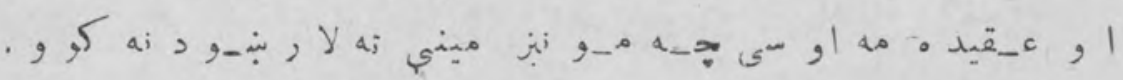

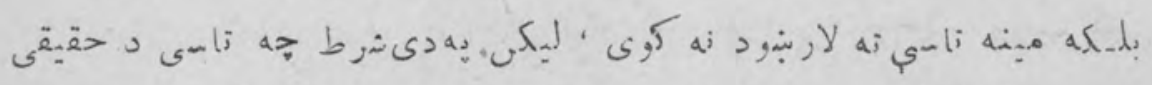

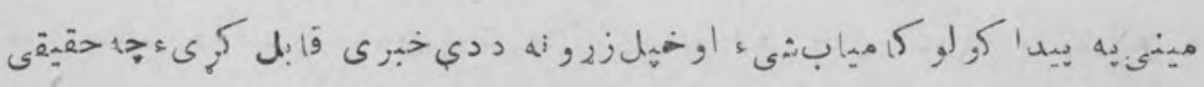
-

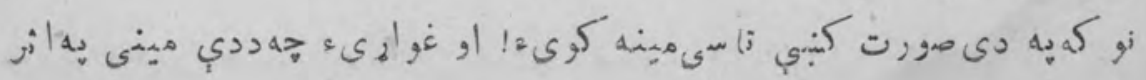




\section{(1乞)}

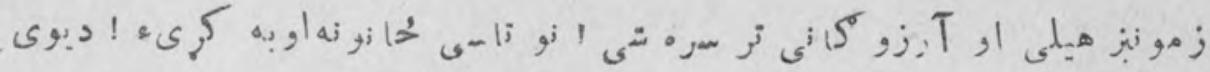

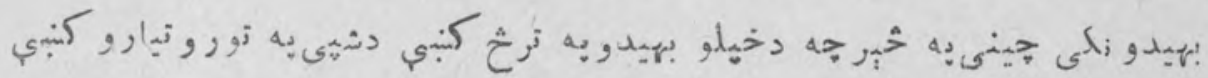
نى

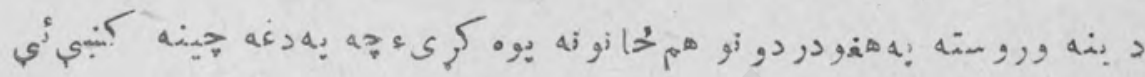

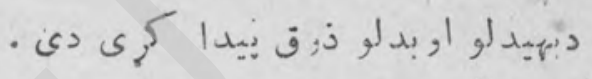

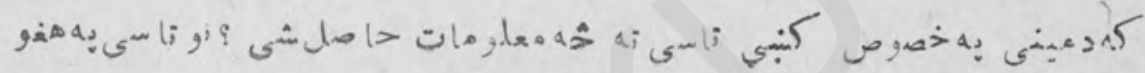
. 2.65 ل

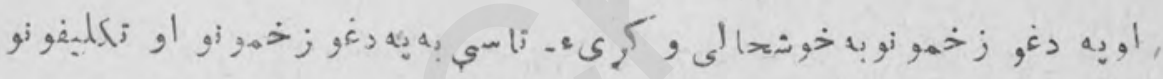

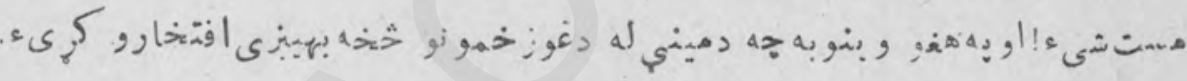

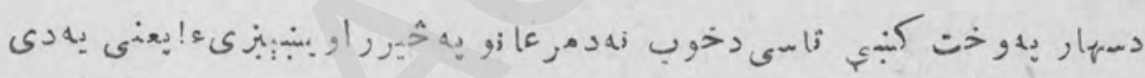

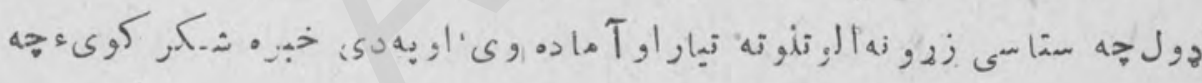

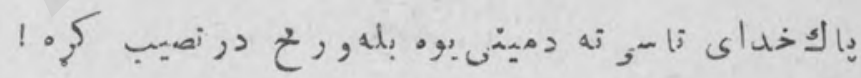

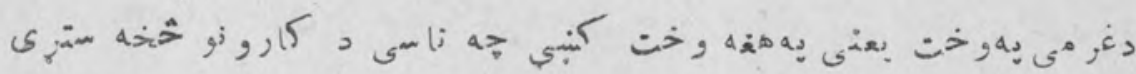

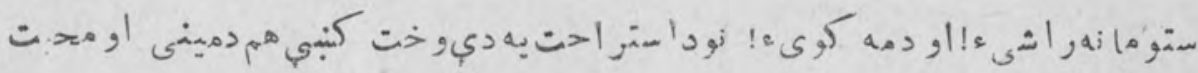

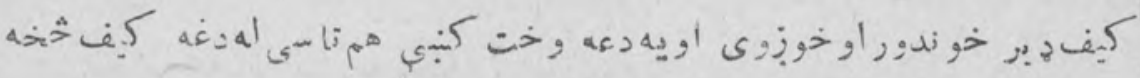

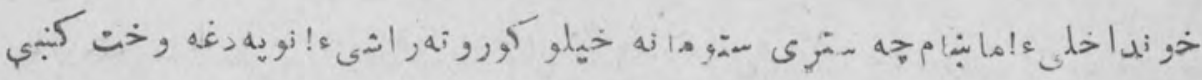

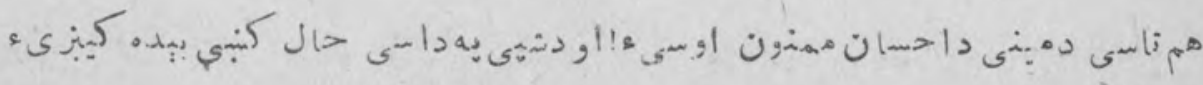

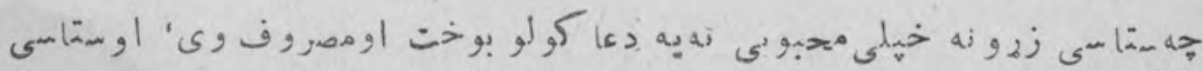

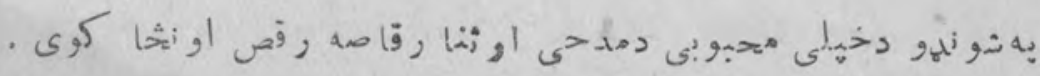




\section{$(10)$}

$-P$.

\section{: بياعار في وبـ}

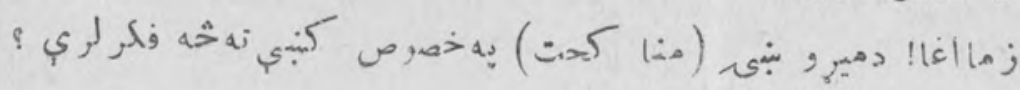
: :

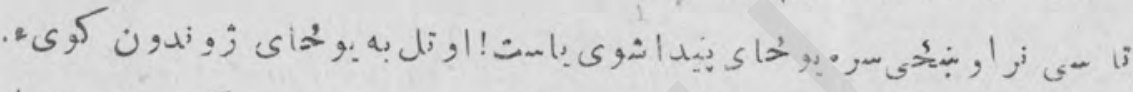

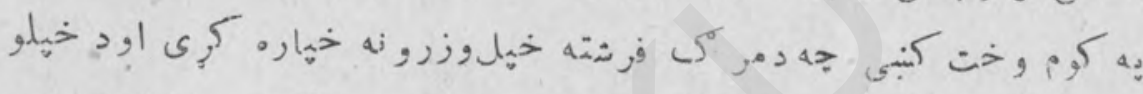

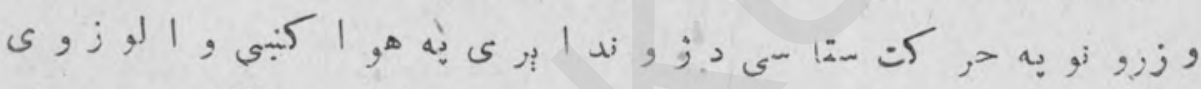

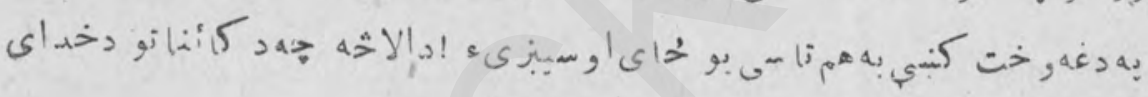

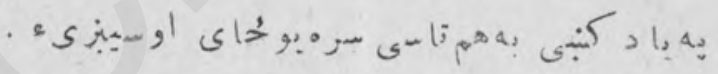

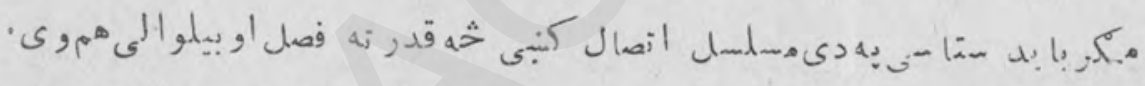

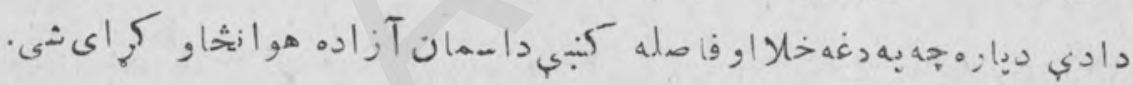

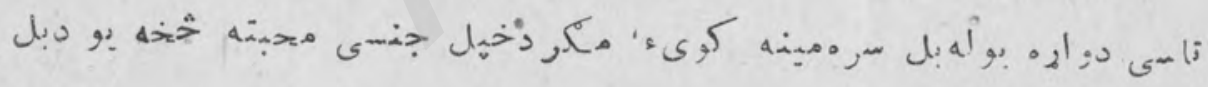

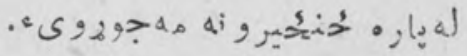

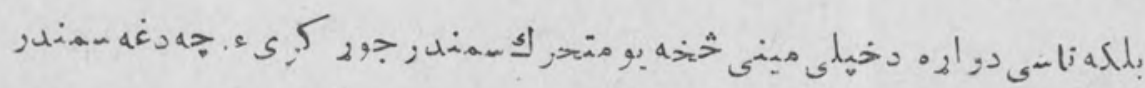

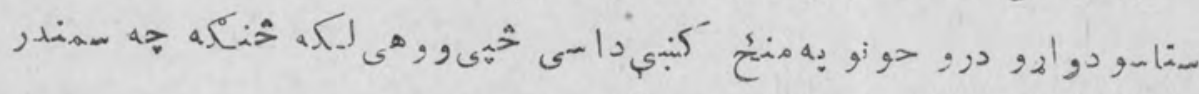

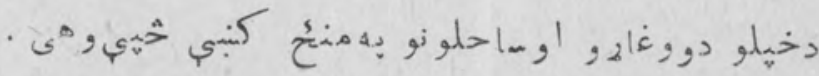

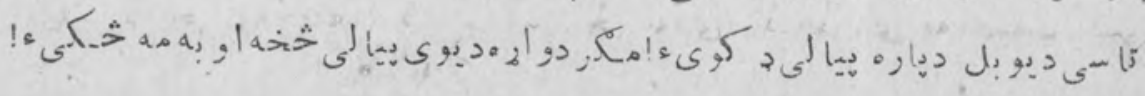

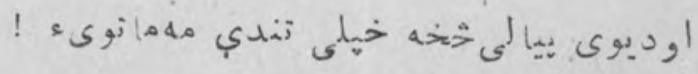

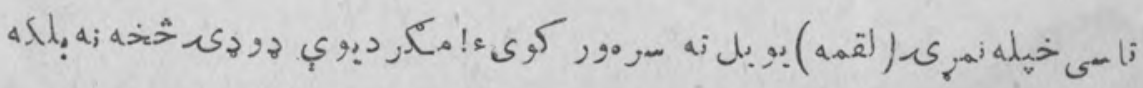
- 2 و 


\section{(19)}

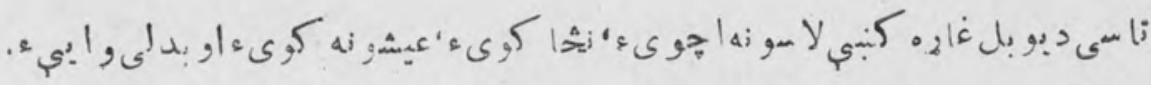

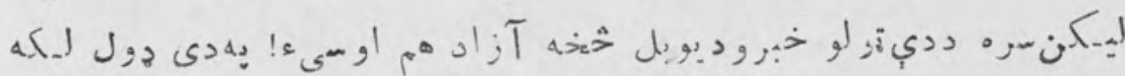

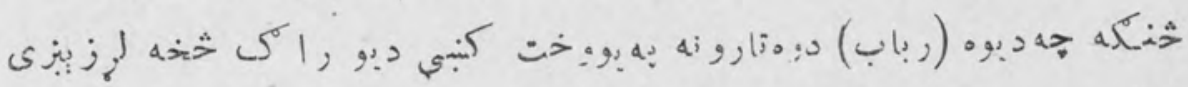

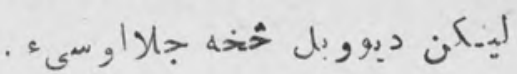
خهل هi هi هi

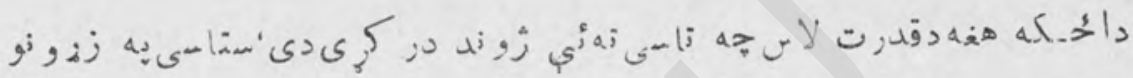

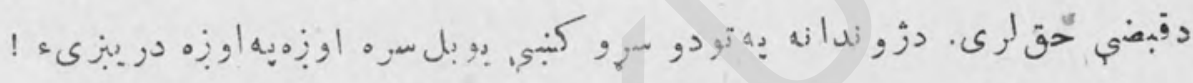

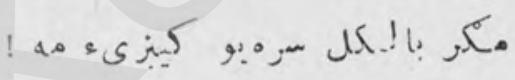

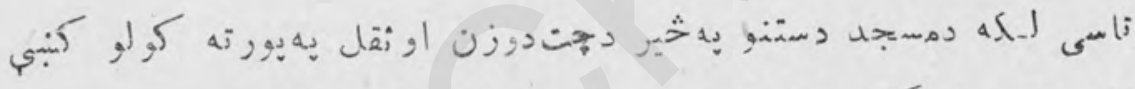

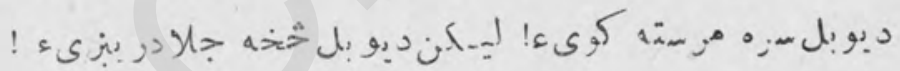

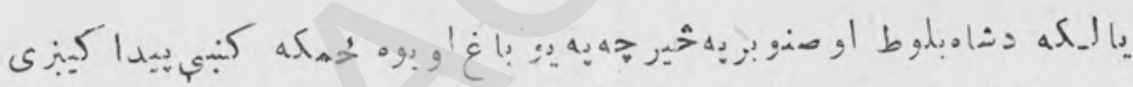

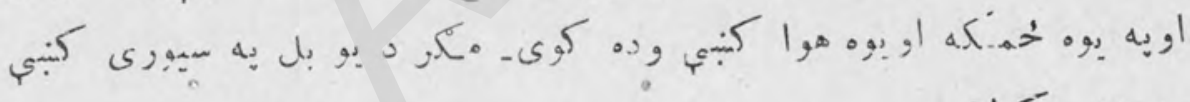
. له $-\&$.

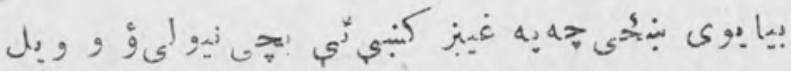

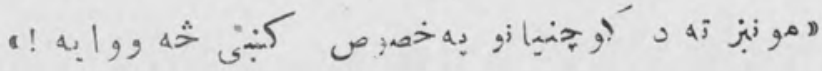
: ه ه

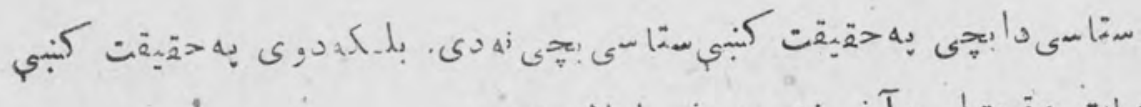

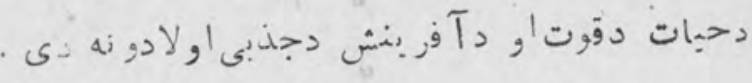

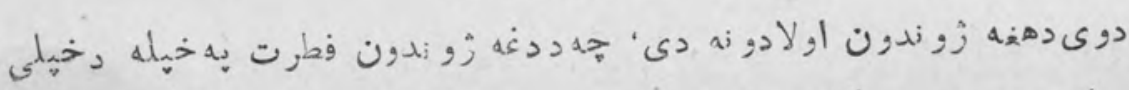
. 


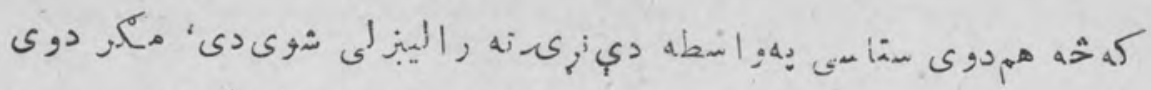

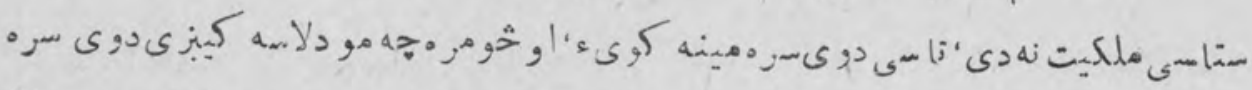

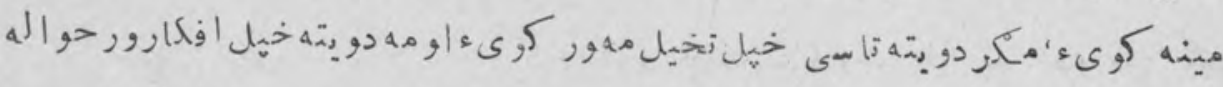

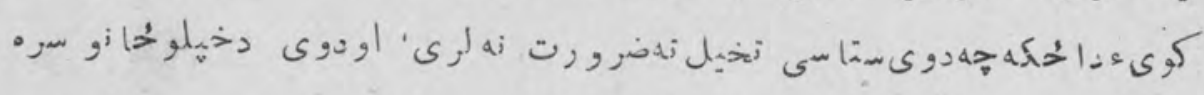

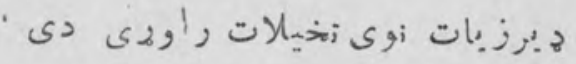

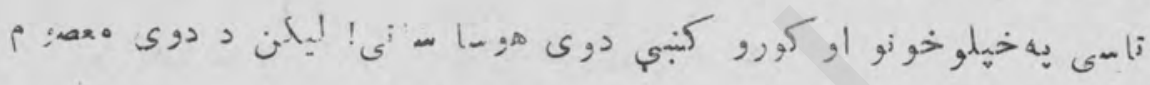

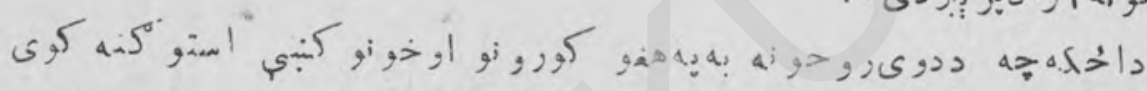

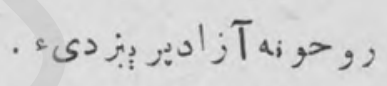

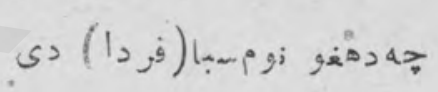

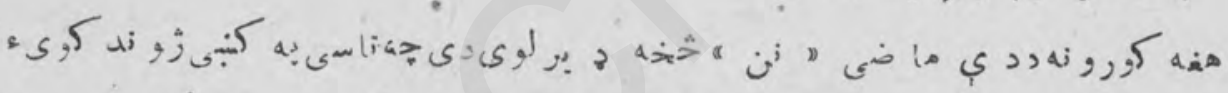

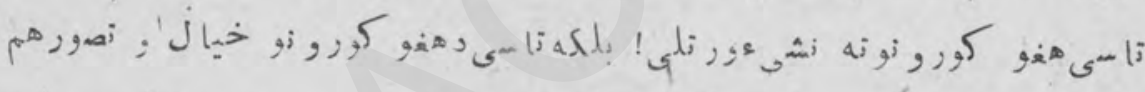

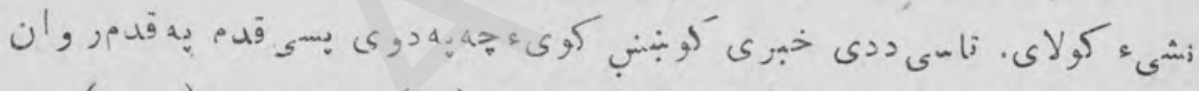

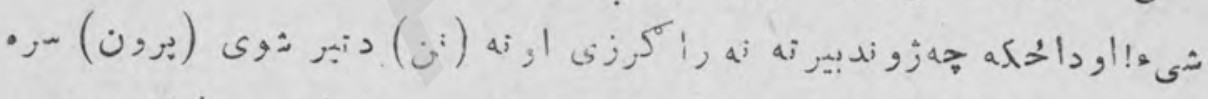

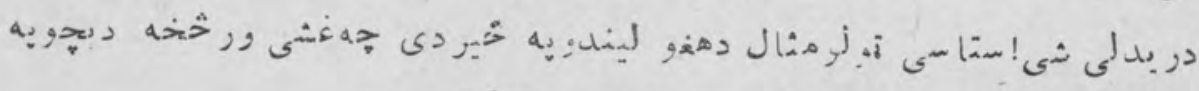

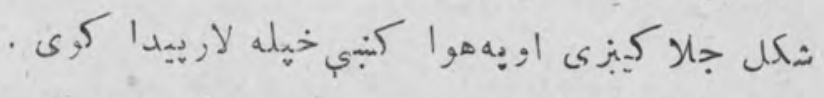

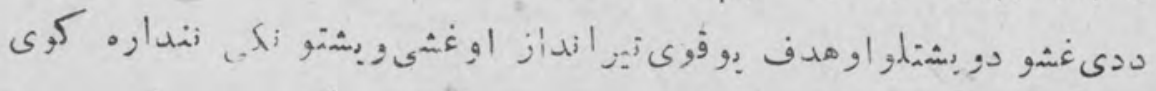

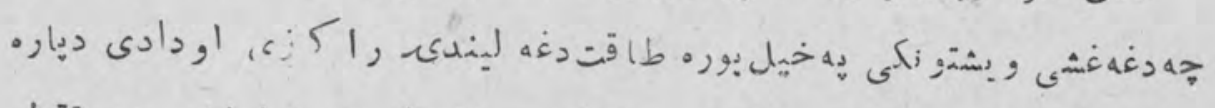

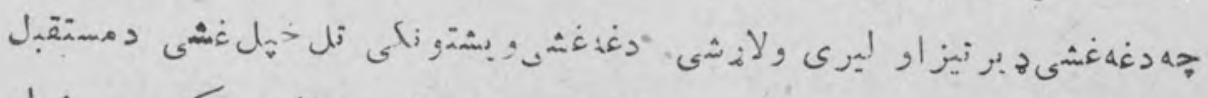

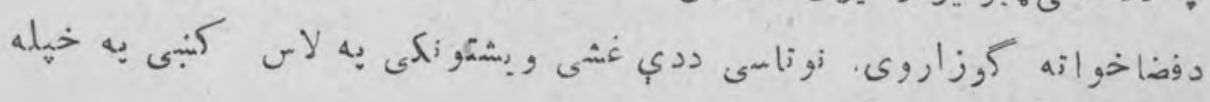
خوبنه آتيته شئ.

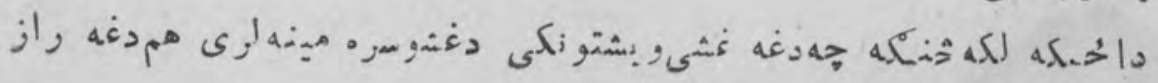


(11)

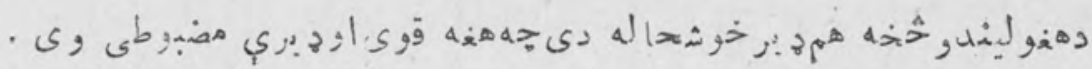
- 0 .

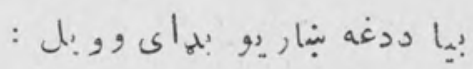

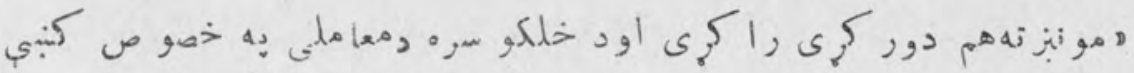

$$
\begin{aligned}
& \text { a!! } 4,1,9,0 \\
& \text { هغنور ته وروبل : }
\end{aligned}
$$

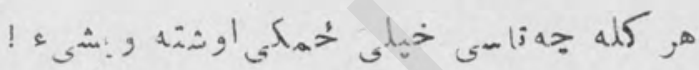

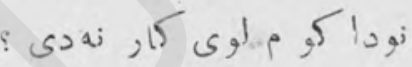

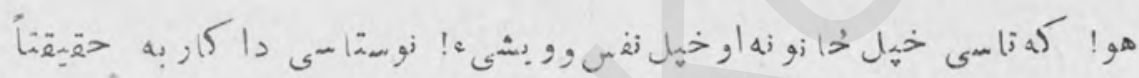

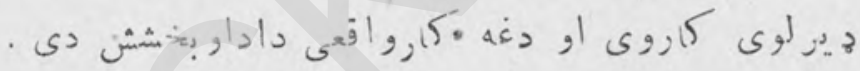

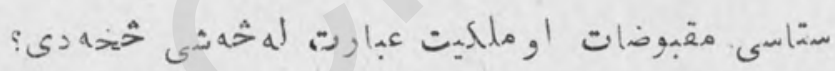

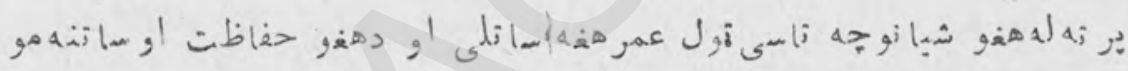

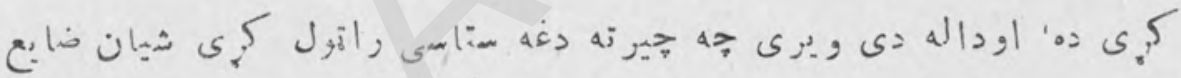

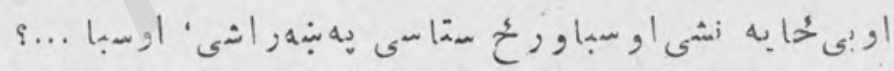

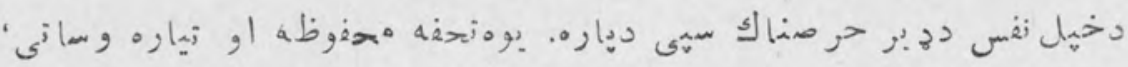

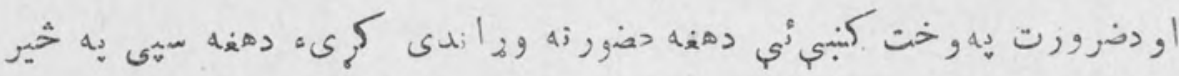

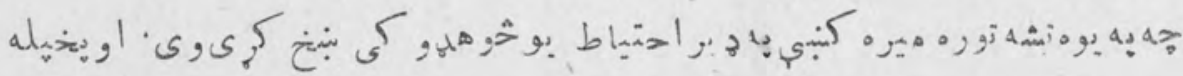

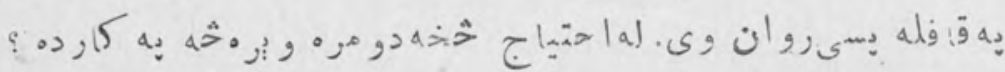

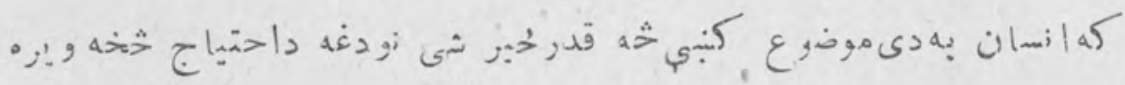

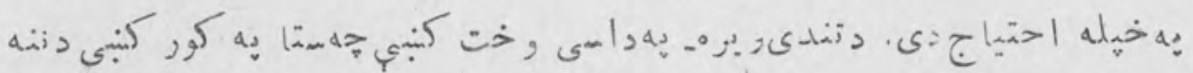

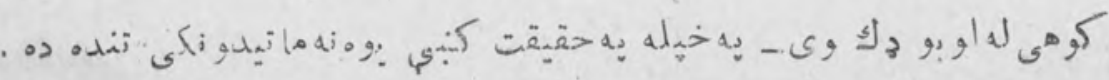




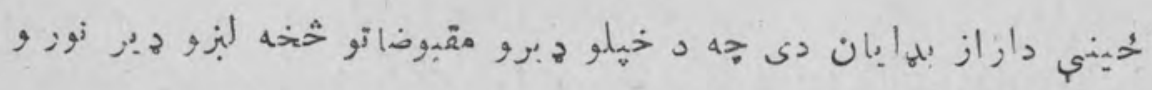
خلمونه همور كوى .

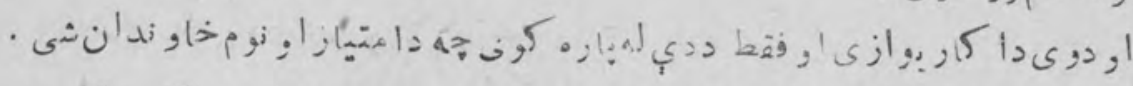

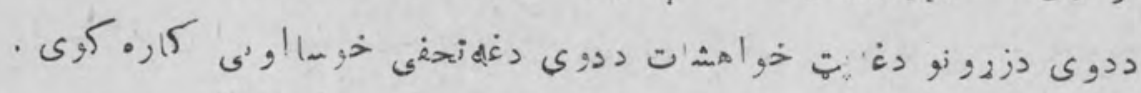

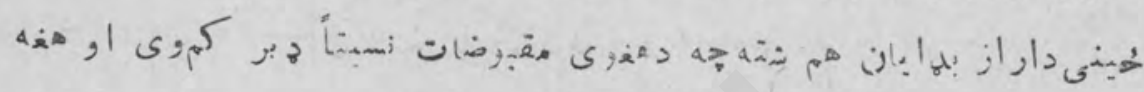

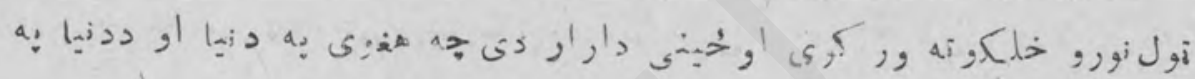

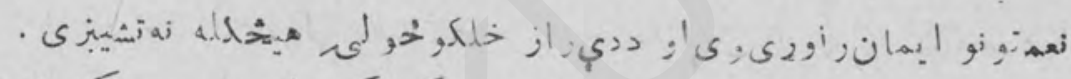

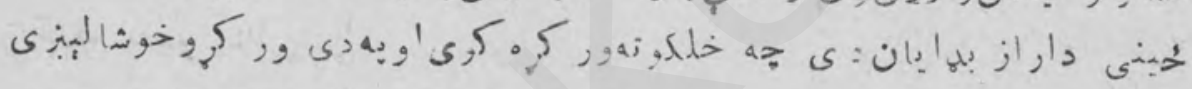

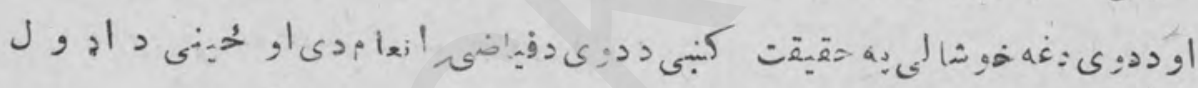

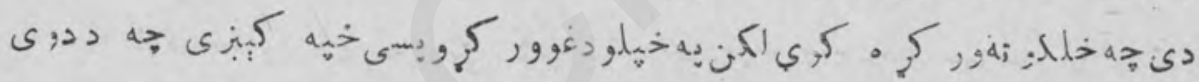

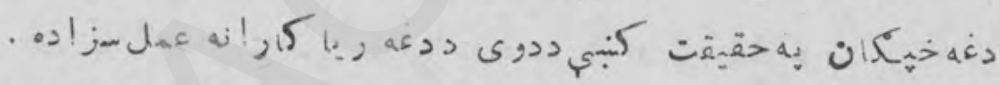

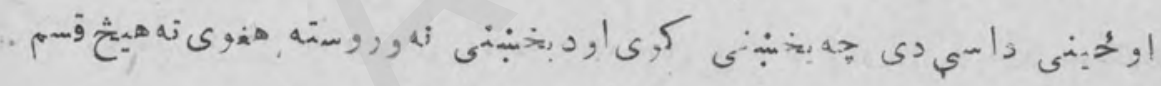

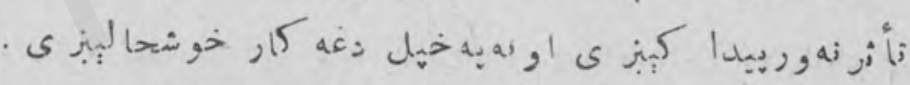

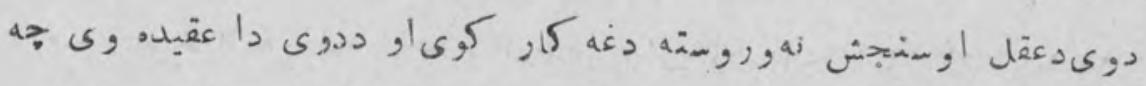

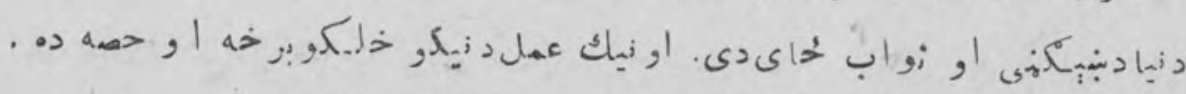

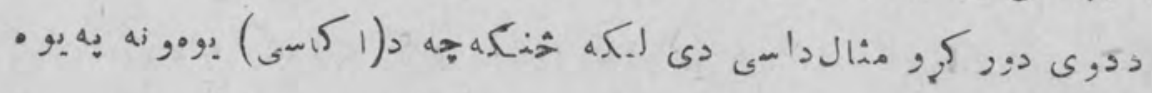

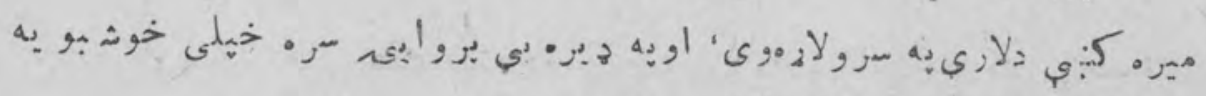

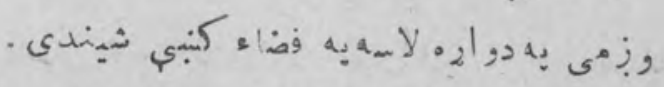

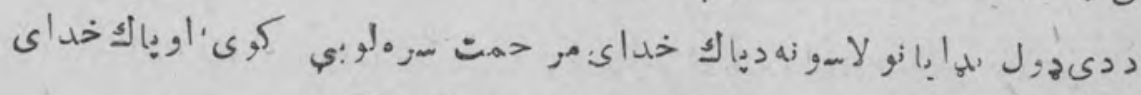

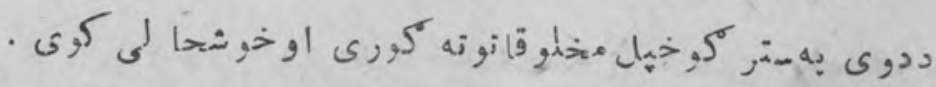

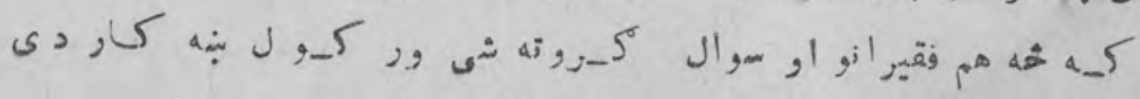




\section{舟下・帝}

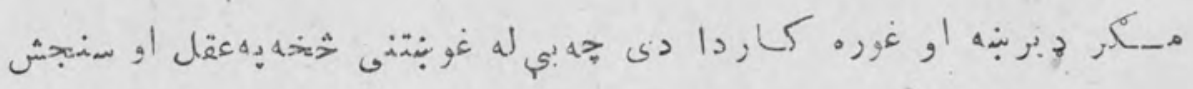

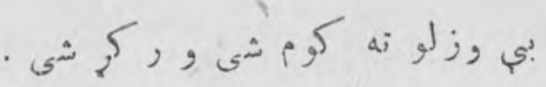

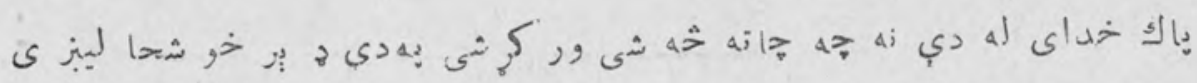

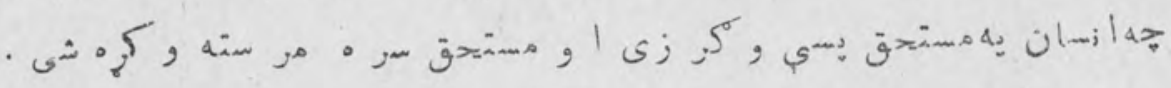

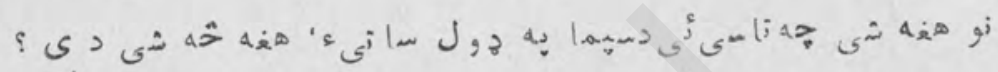

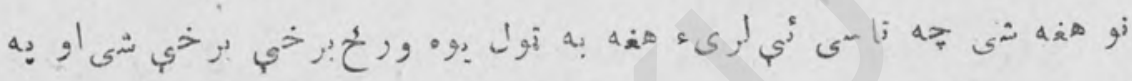

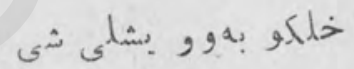

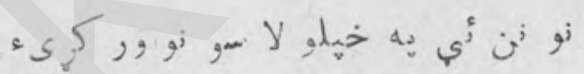

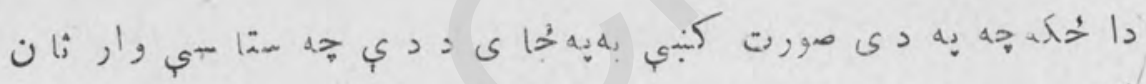

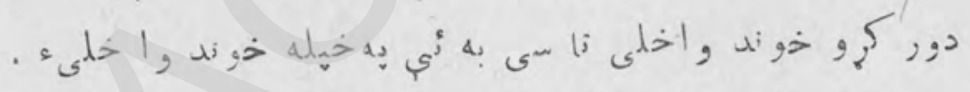

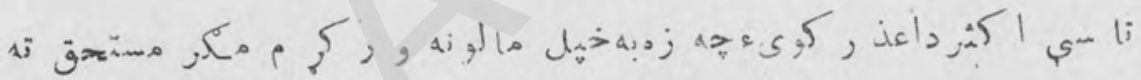

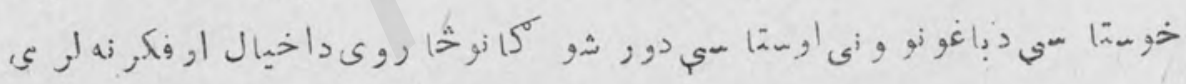
دورى

$$
\text { . ل }
$$

$$
\text { كه }
$$

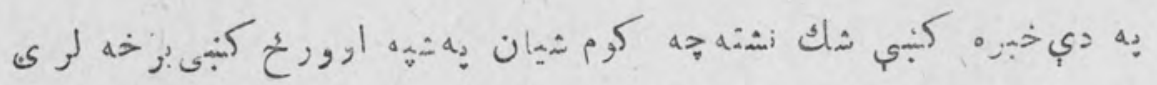

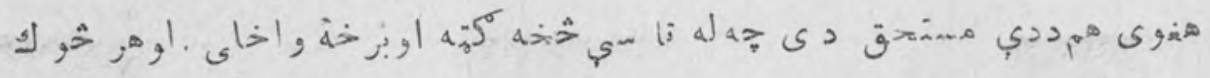

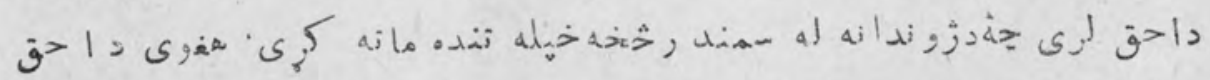

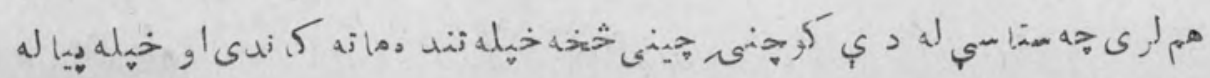
$\pi_{2} 2_{2}$ 


\section{(4)}

$$
\text { i }
$$

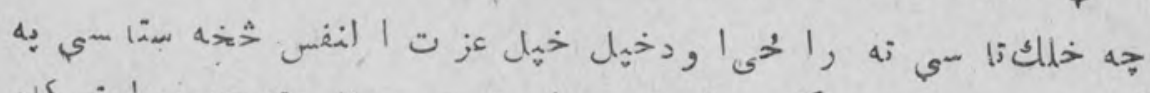

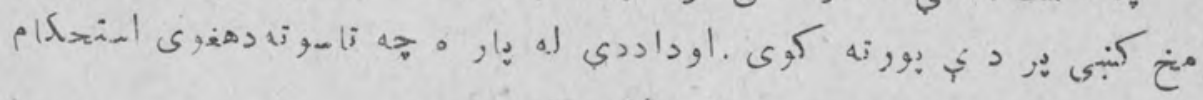

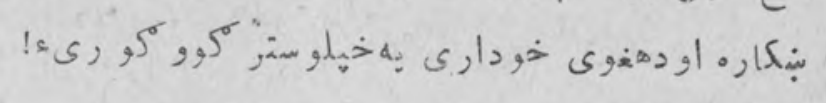

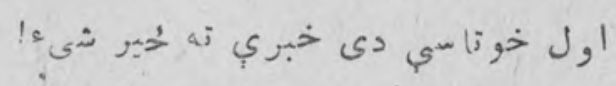

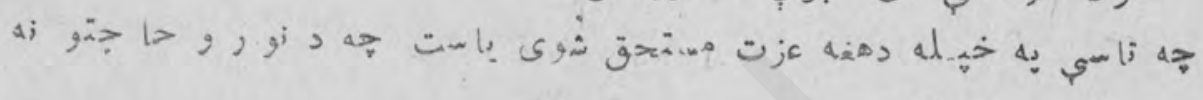

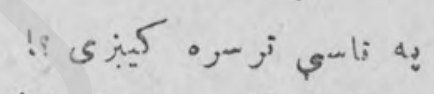

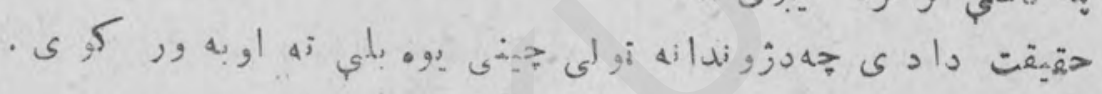

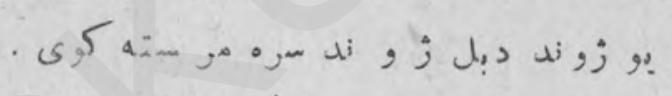

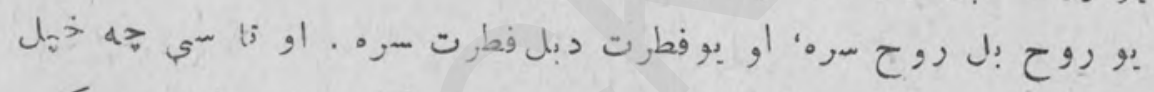

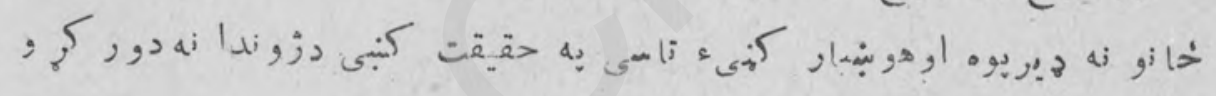

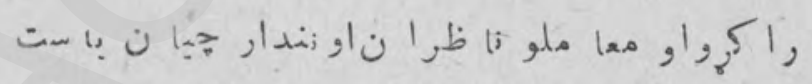

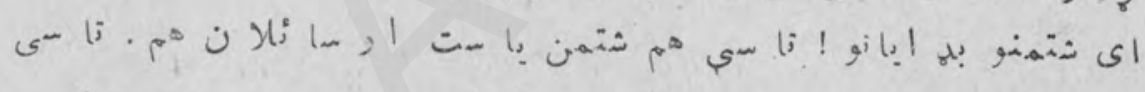

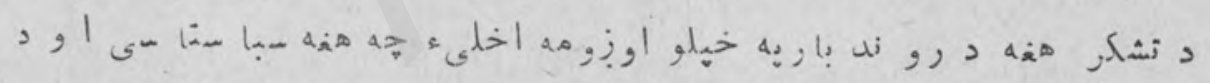

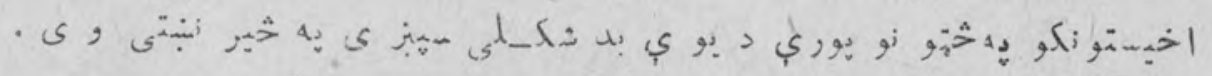

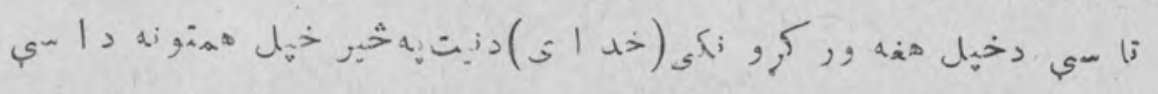

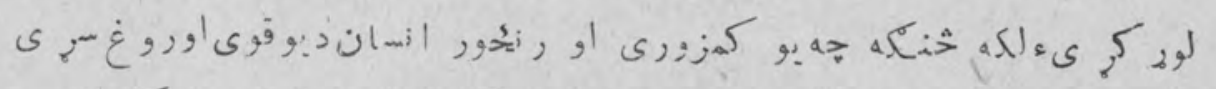

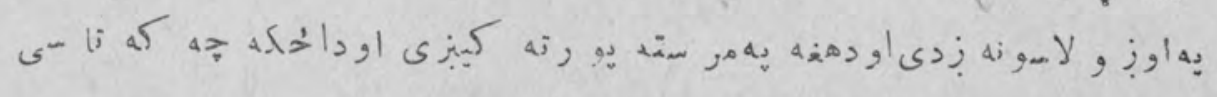

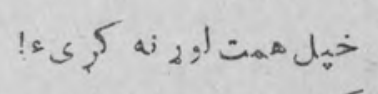

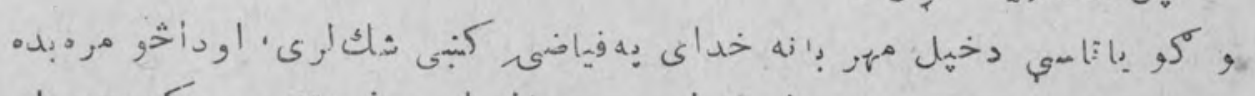

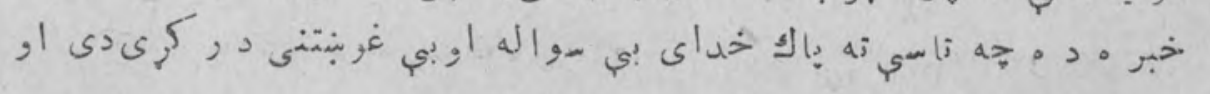

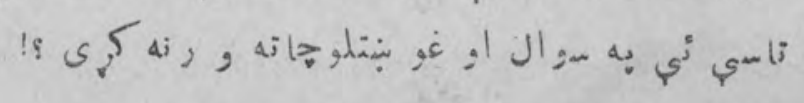




\section{(x)}

$-1$

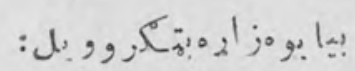

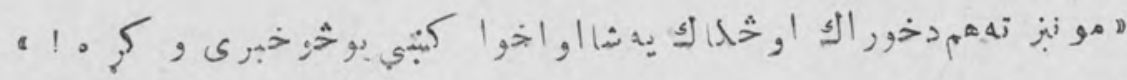

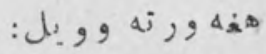

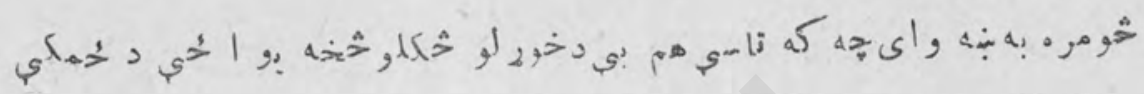

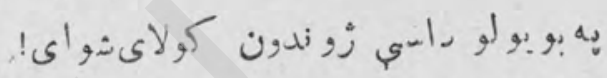

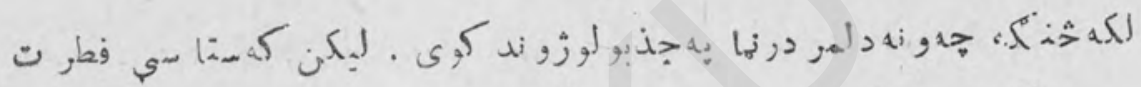

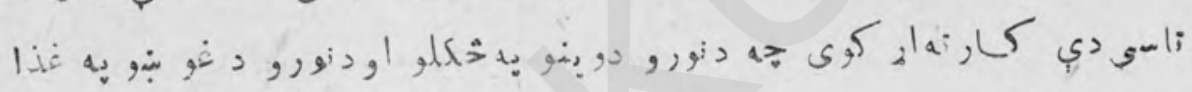

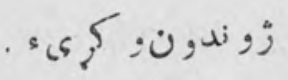

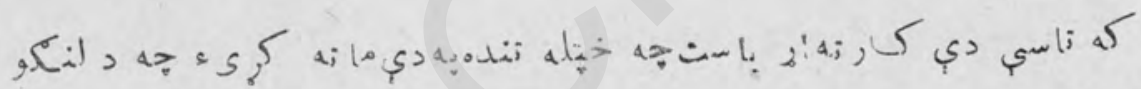

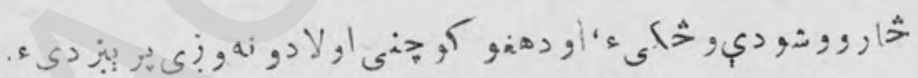

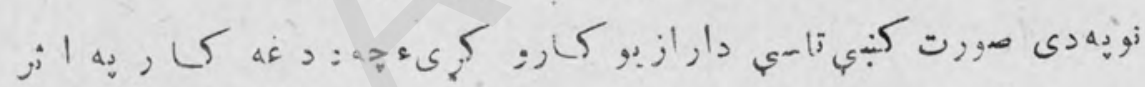

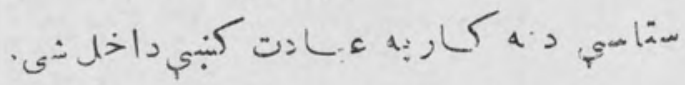

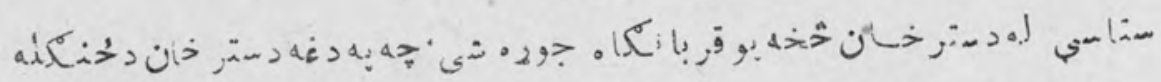

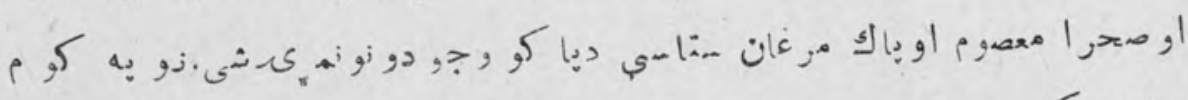

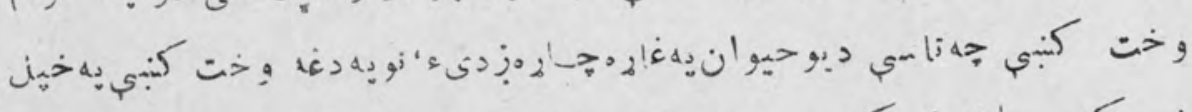

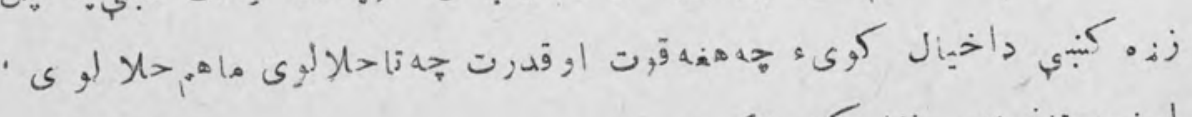

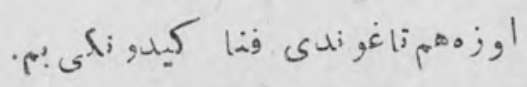

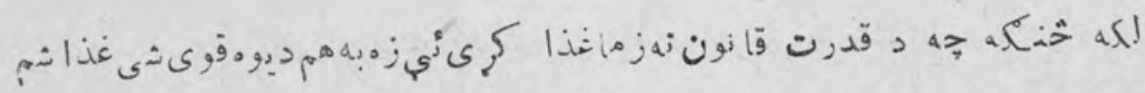

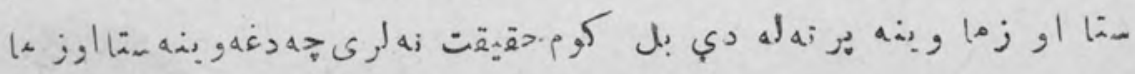




\section{(ACKU: \\ $(4)^{2}$}

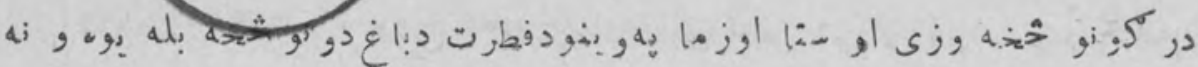
i

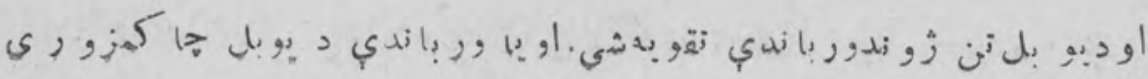

$$
\begin{aligned}
& \text { جو, و פوى شى }
\end{aligned}
$$

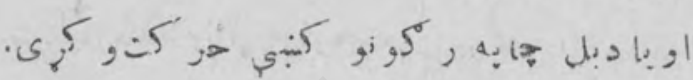

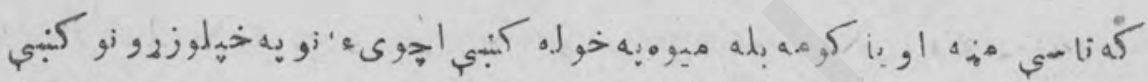

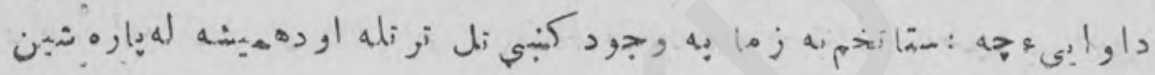

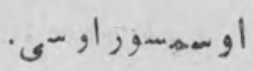

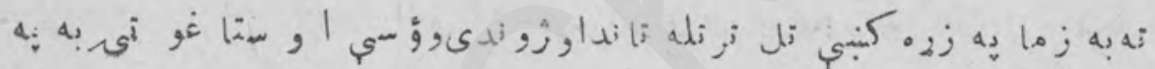

$$
\text { را }
$$

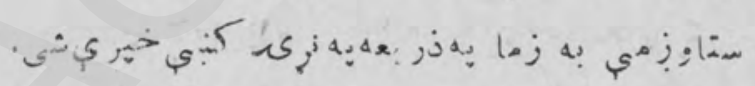

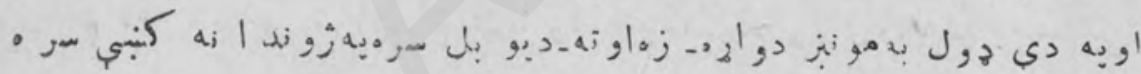

$$
\text { شر. }
$$

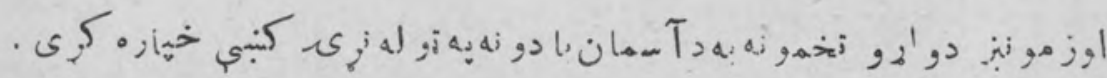

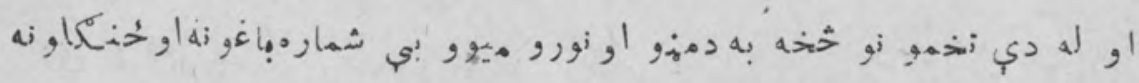

$$
\text { ! }
$$

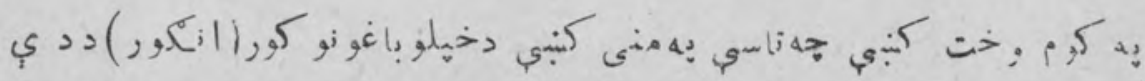
ل له

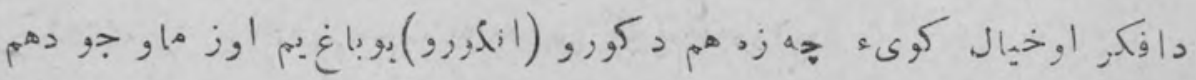

$$
\text { .0s a }
$$




\section{\&ro}

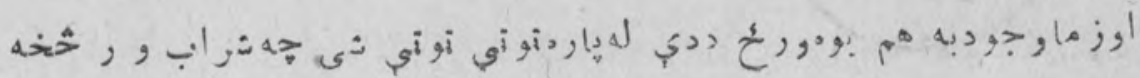
جونشى.

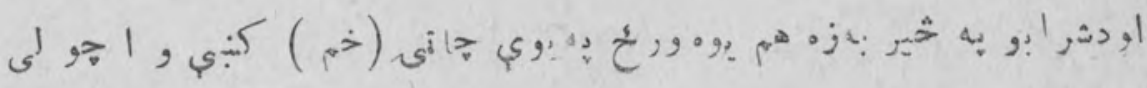

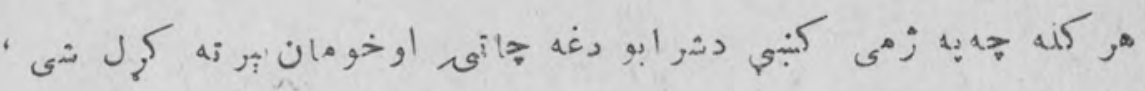

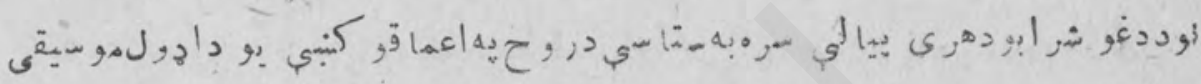

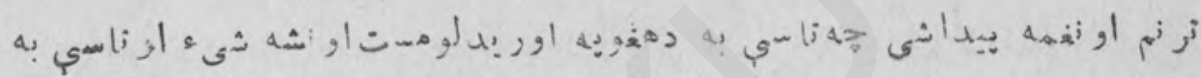

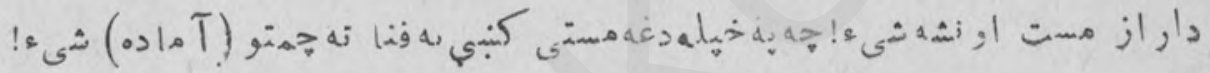

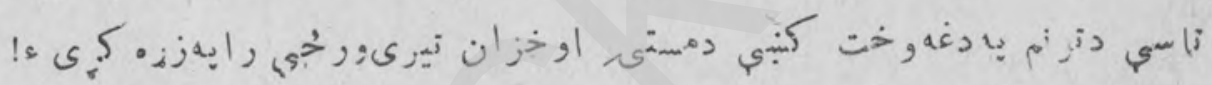

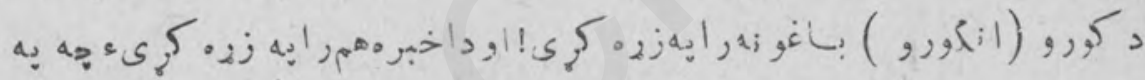

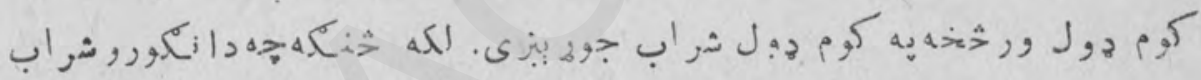

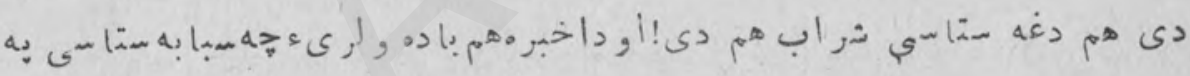

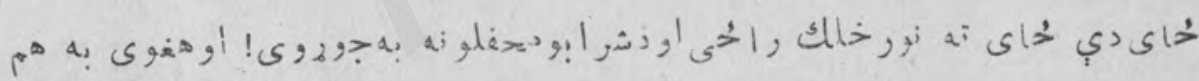

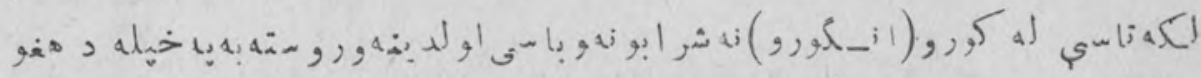

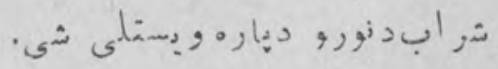
دوجة

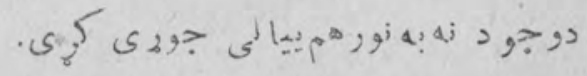
$-v$.

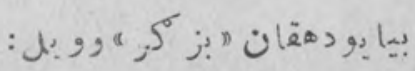

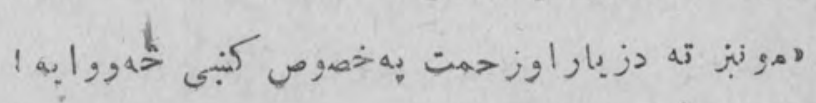
: 


\section{(r)}

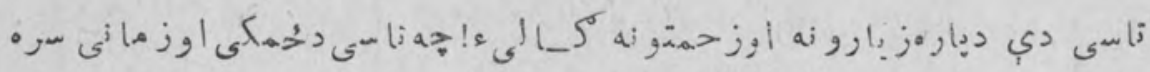

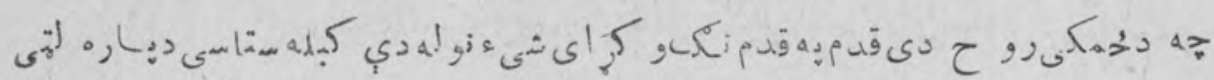

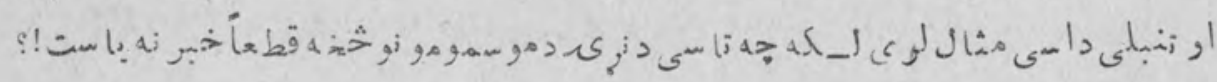

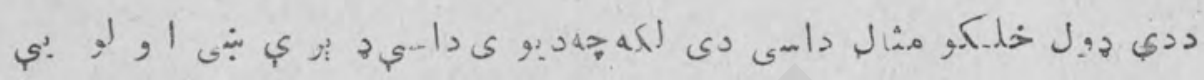

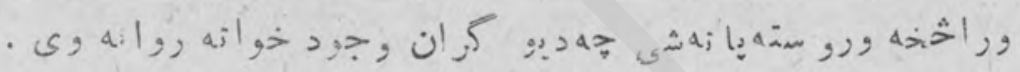

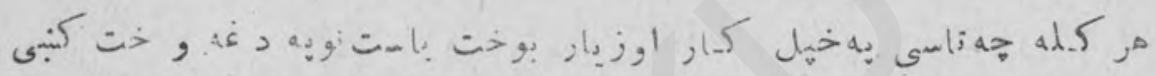

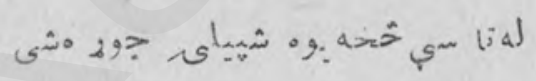

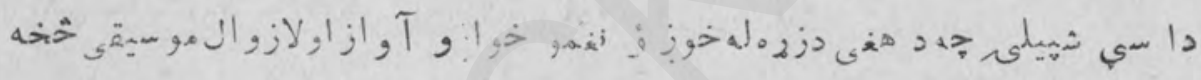

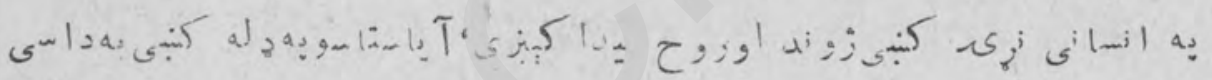

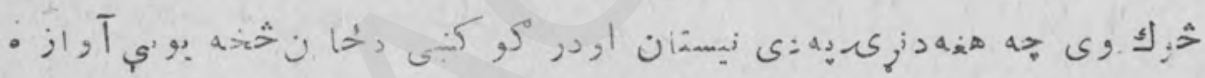

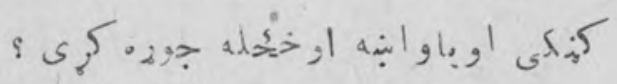

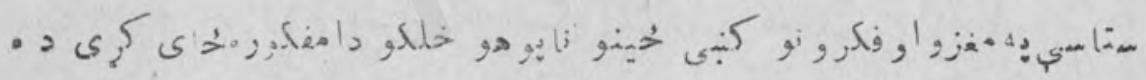

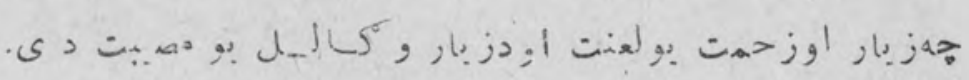

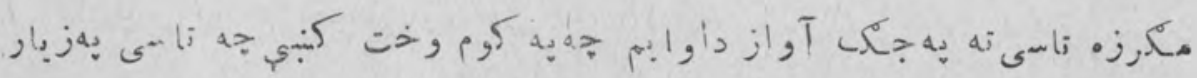

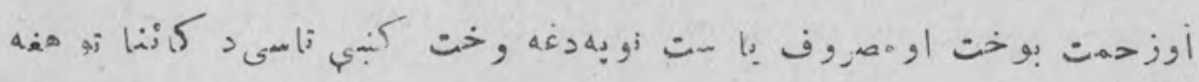

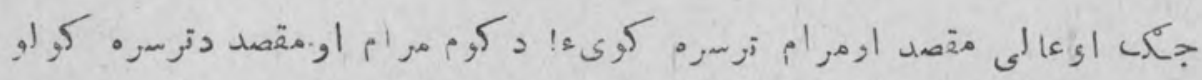

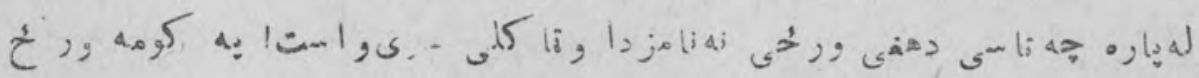

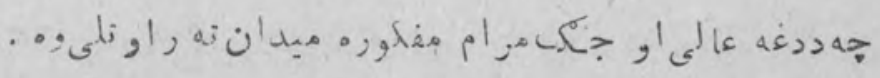

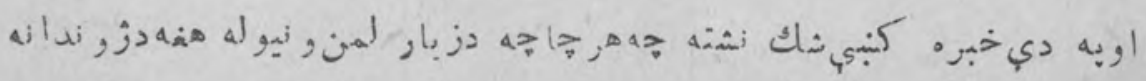

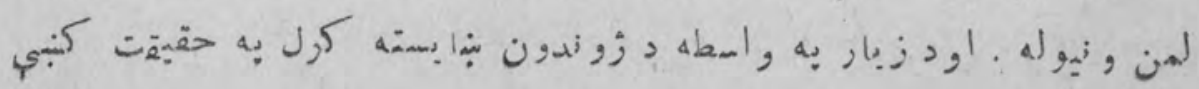




\section{4 ri}

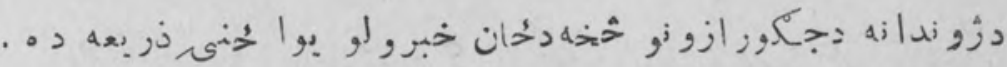

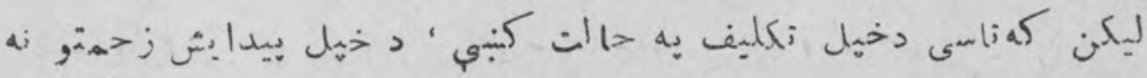

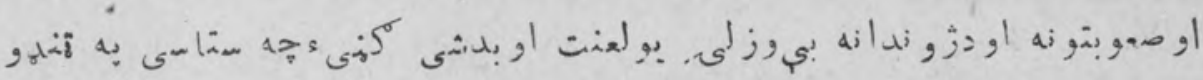
- مان

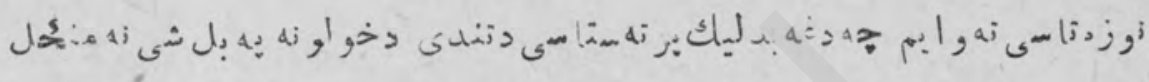
كمبن

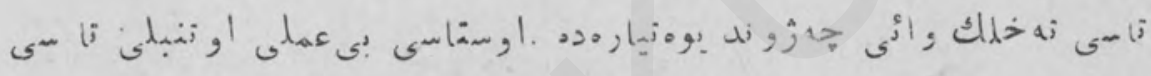

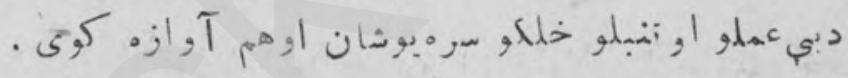

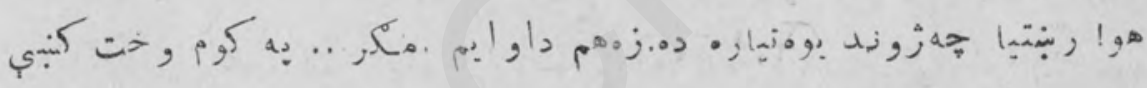
إنهإ.

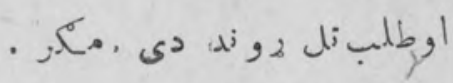

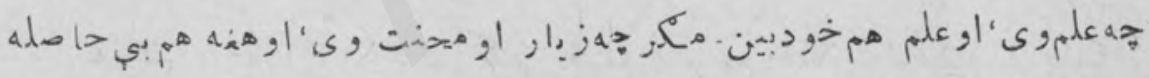

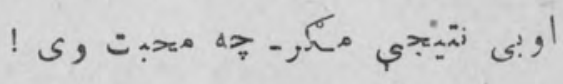

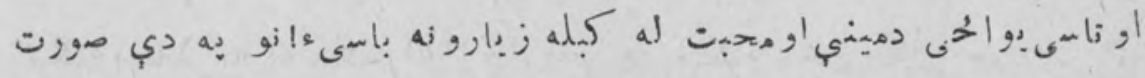

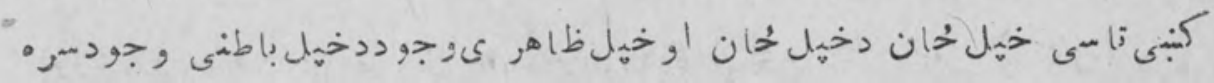

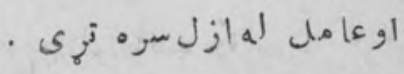

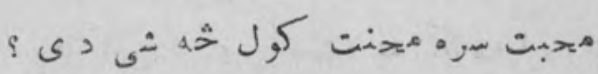

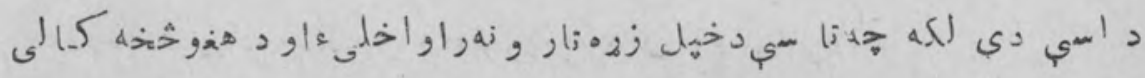
اوبدعءا

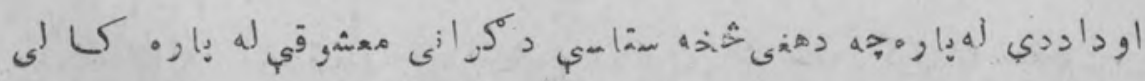




\section{$\langle r|$}

.

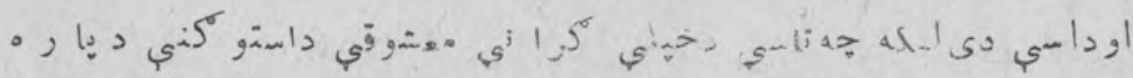

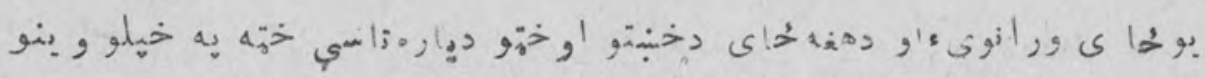

$$
\text { ls } \sqrt{2}, 5 \text { aiि }
$$

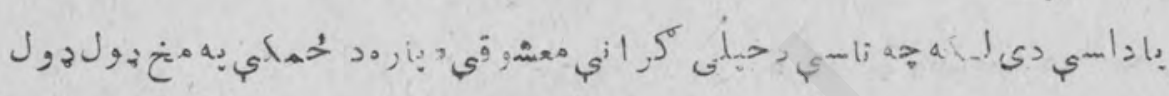

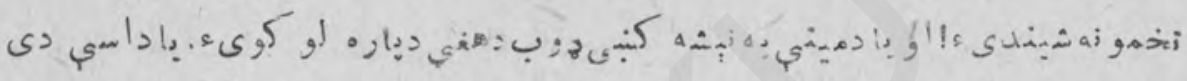

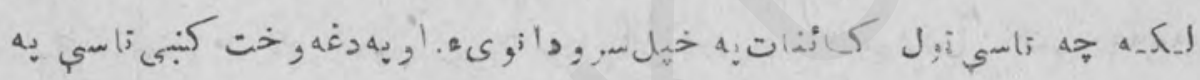

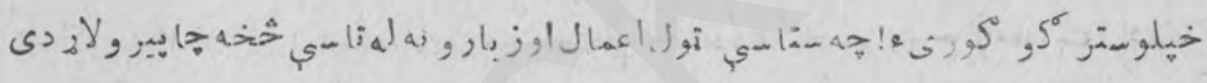

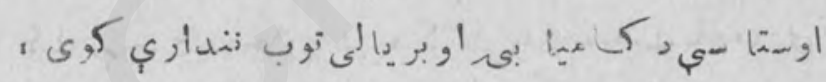

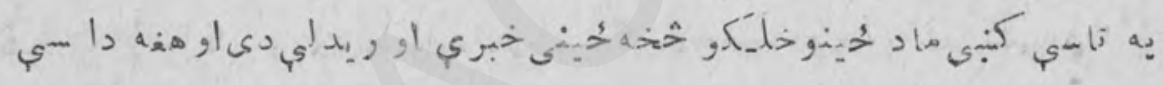

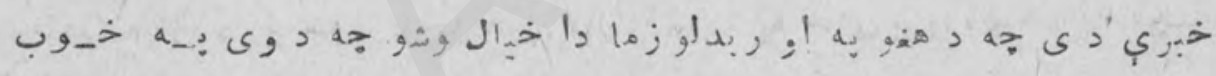

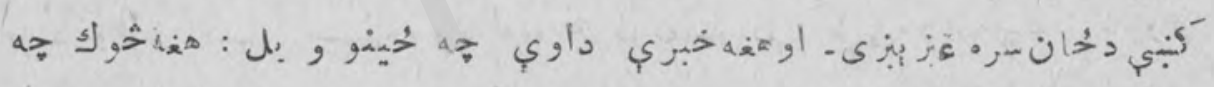

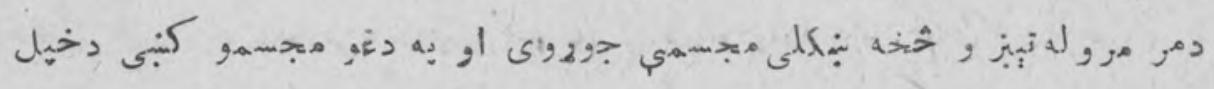

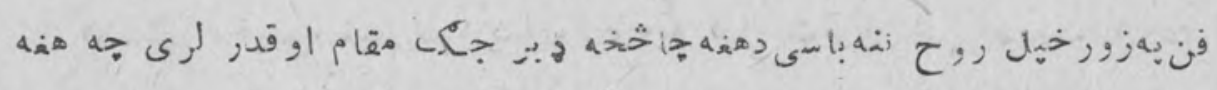

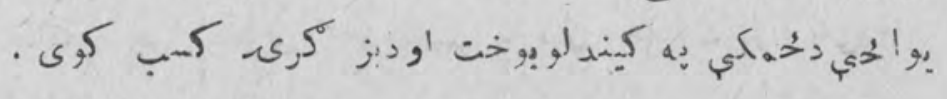

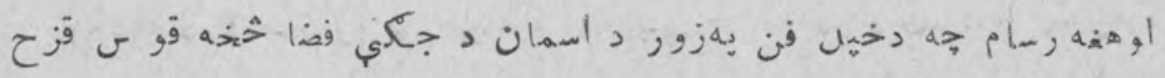

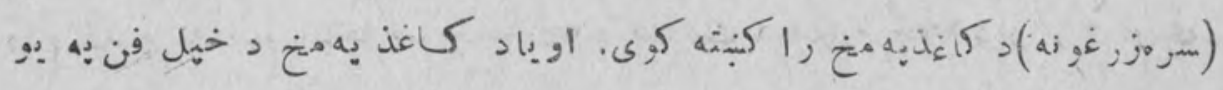

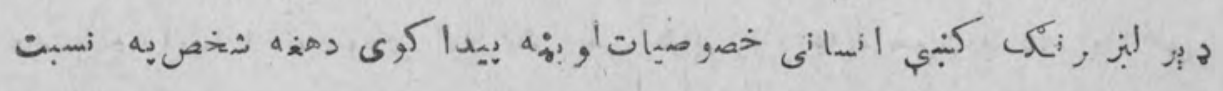

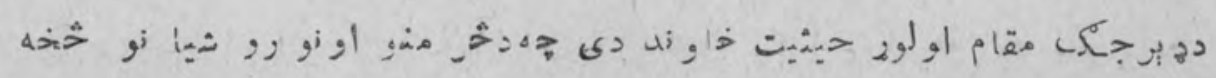

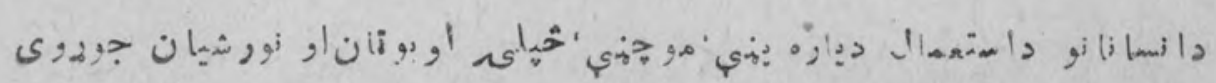




\section{४ง}

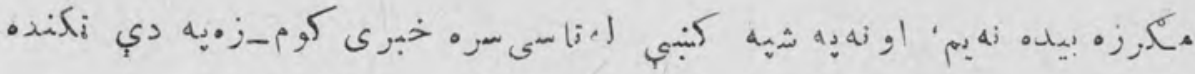

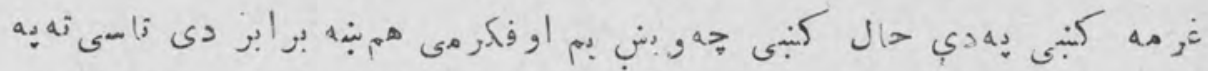

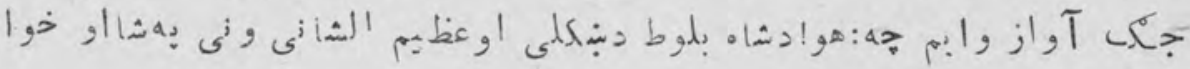

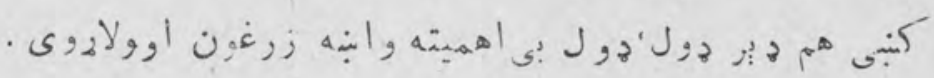

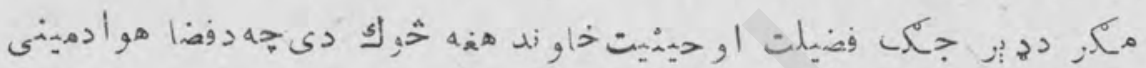
.

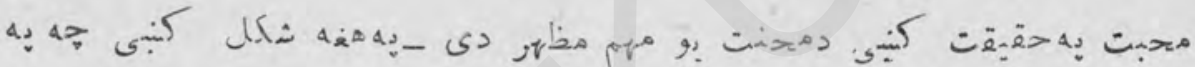

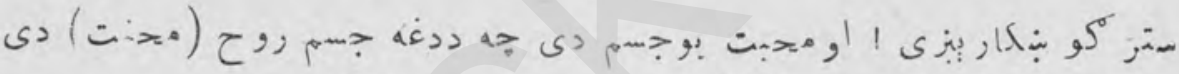

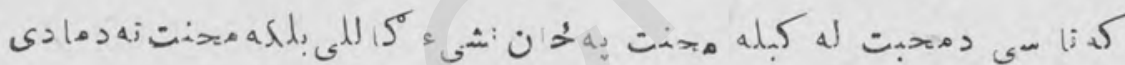

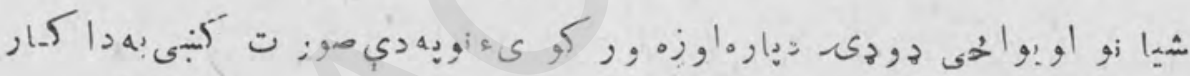

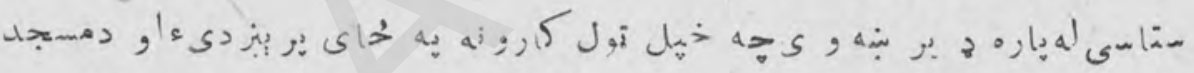

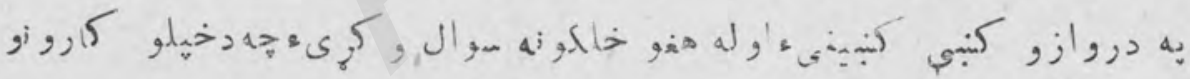

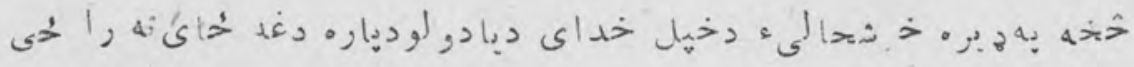

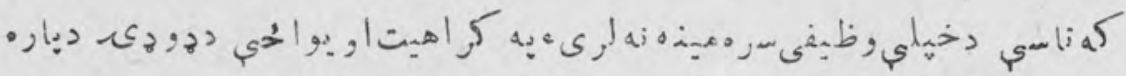

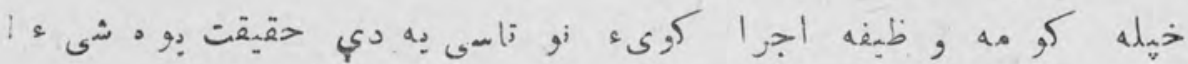

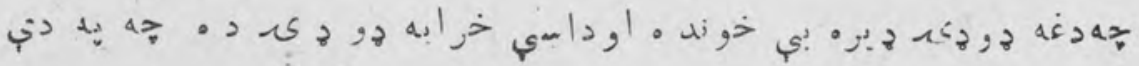
ح

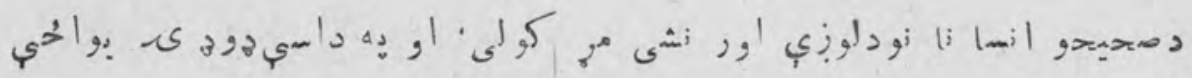

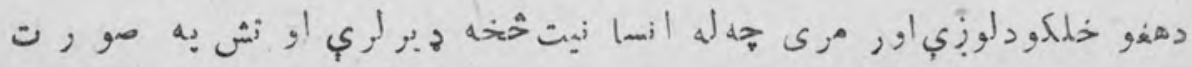

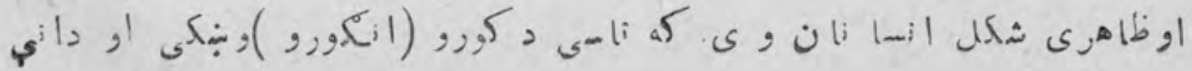




\section{4rat}

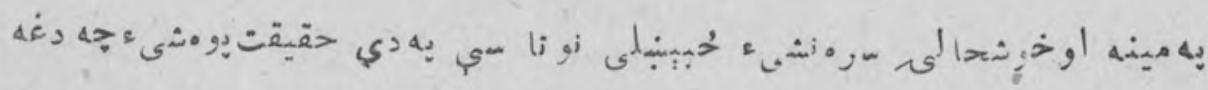

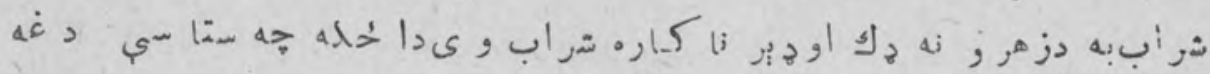

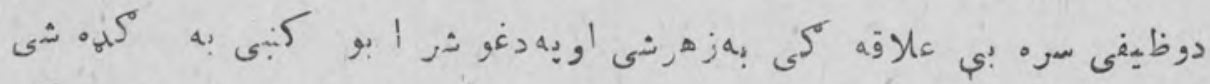

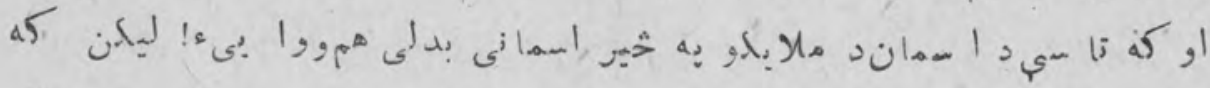

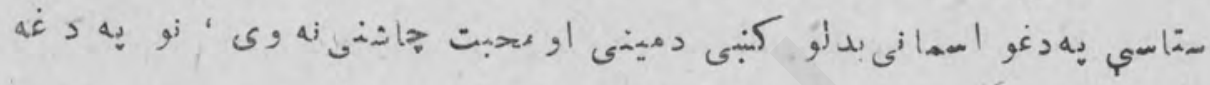

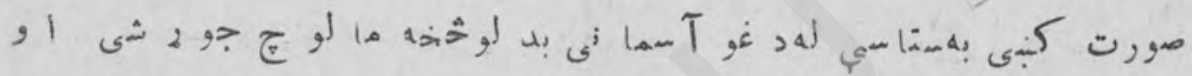

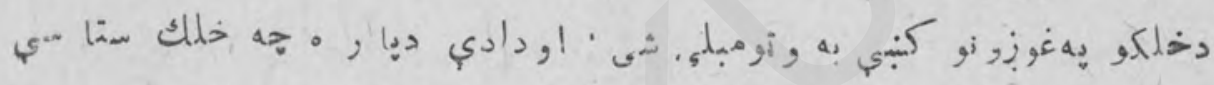
- دغ اغه إنهى

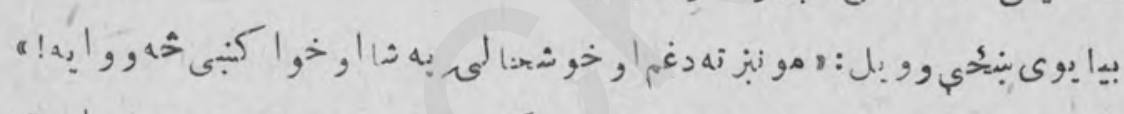

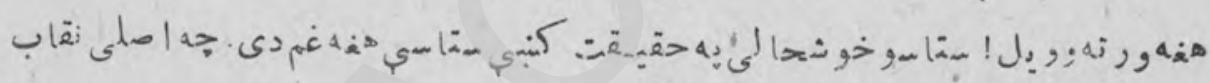

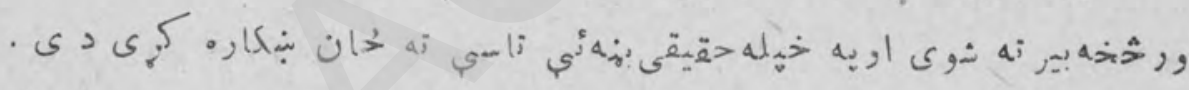

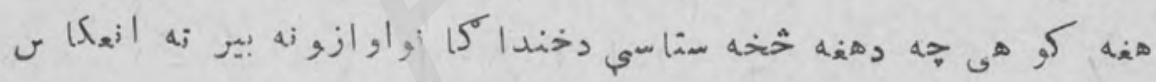

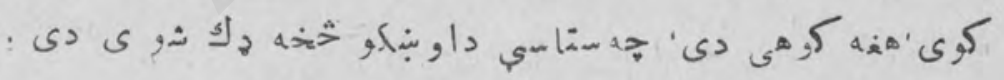

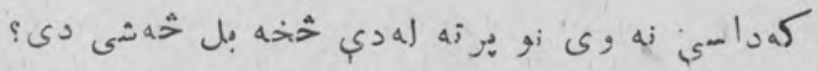

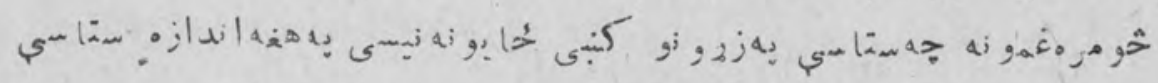

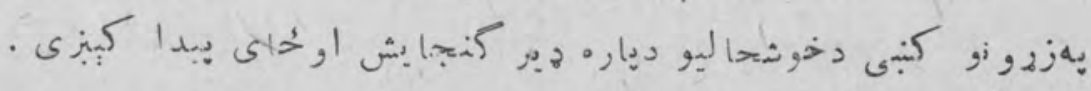

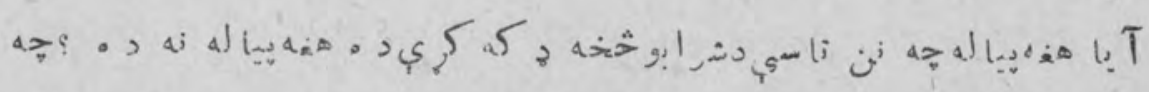

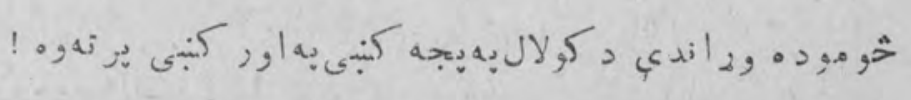

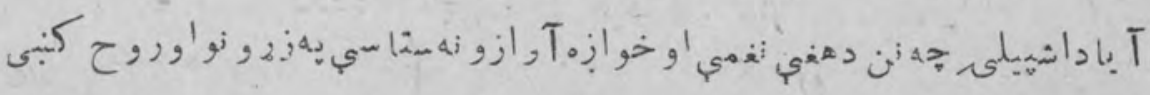

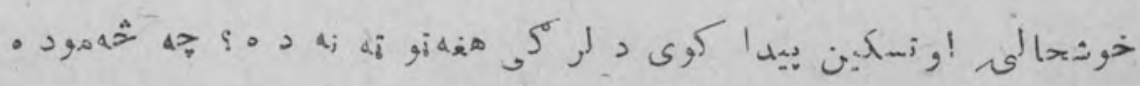




\section{$\alpha+$}

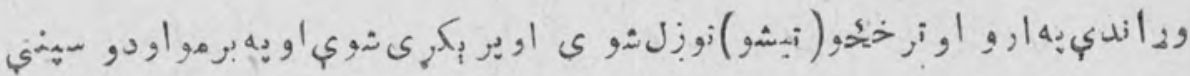

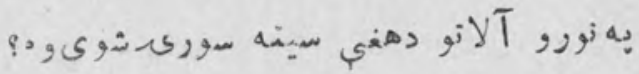

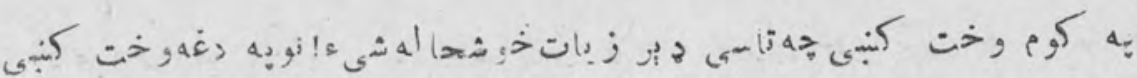

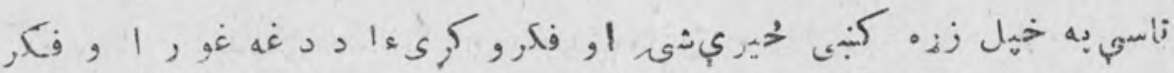

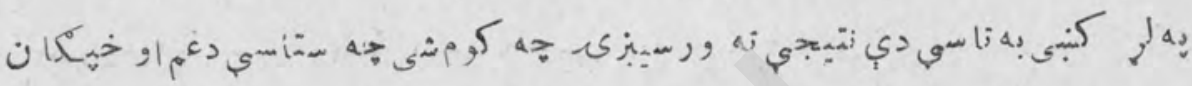

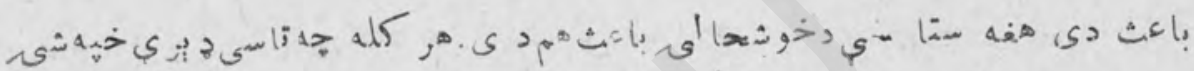
نو

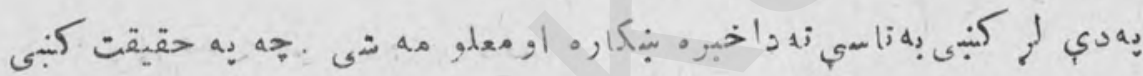

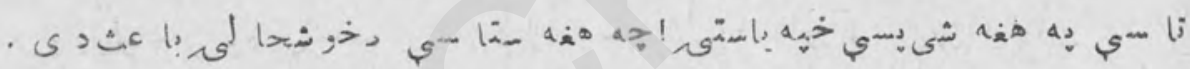

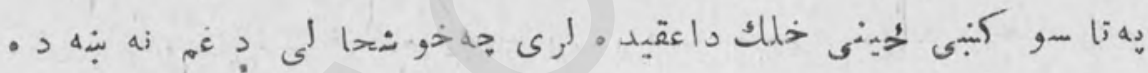

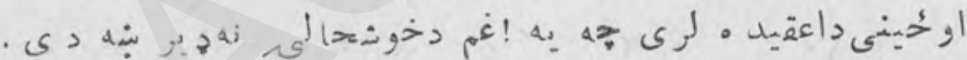

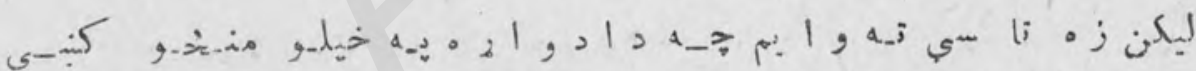

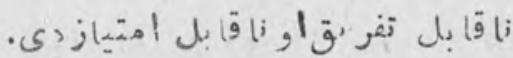

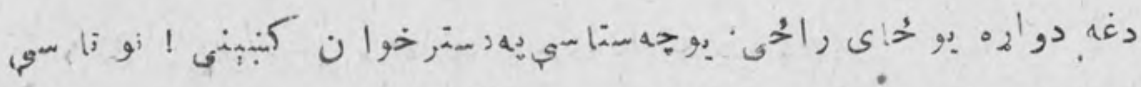

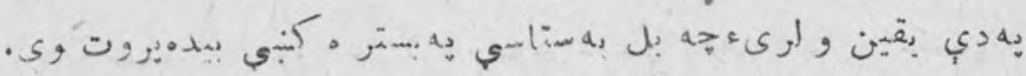

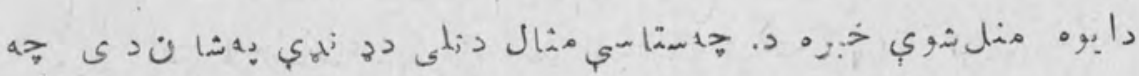

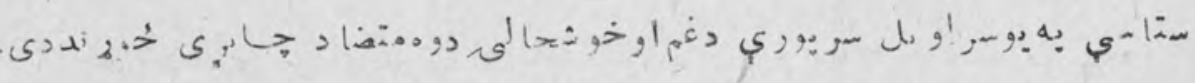

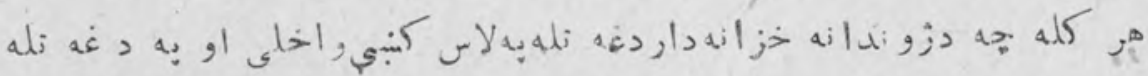

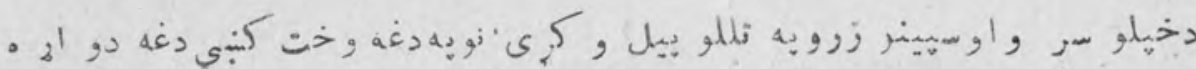

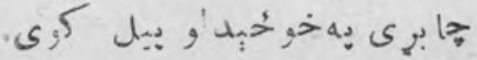

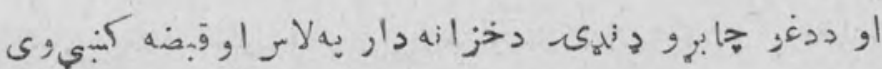


(ri)

$-9$.

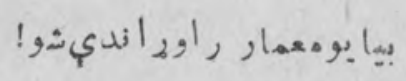

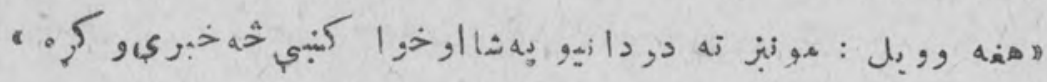

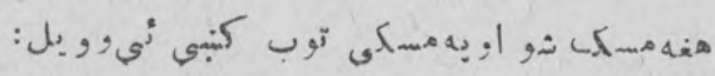

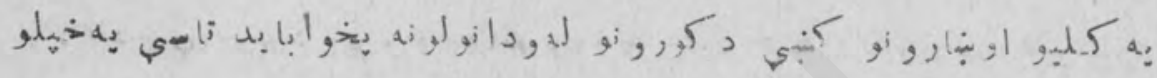

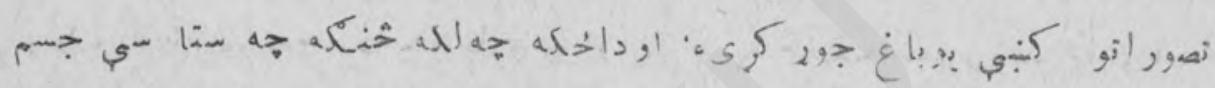

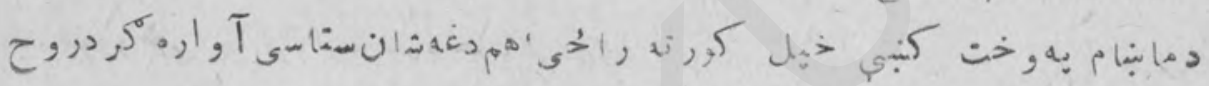
.

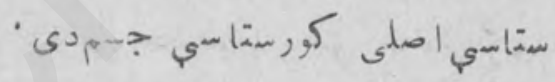

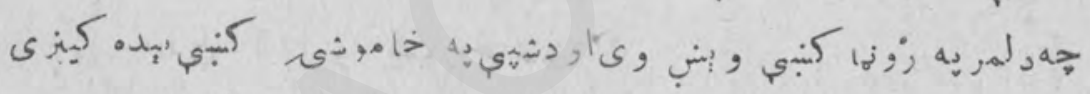

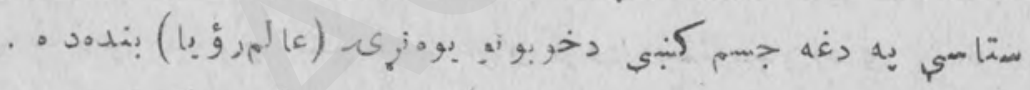

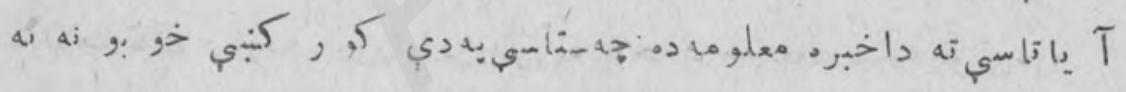

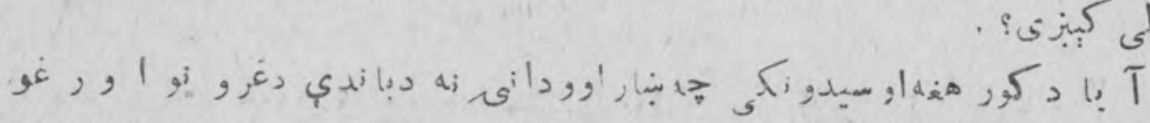

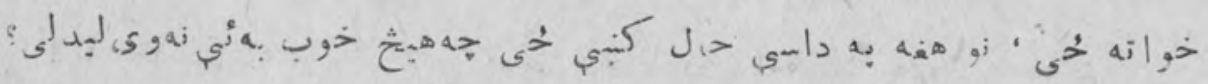

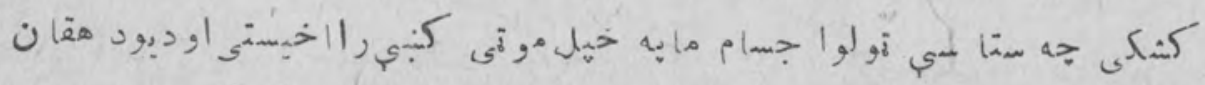

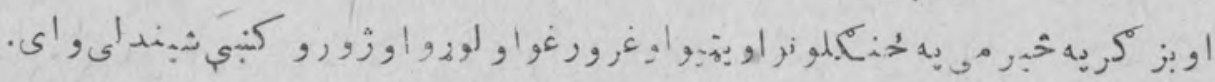

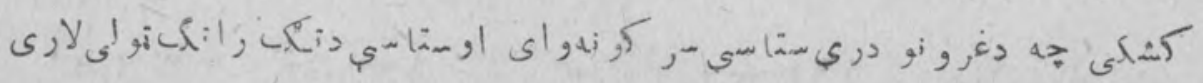

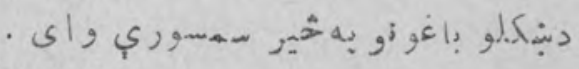

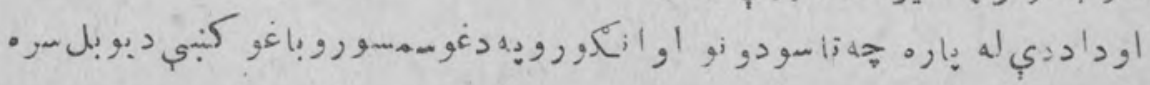

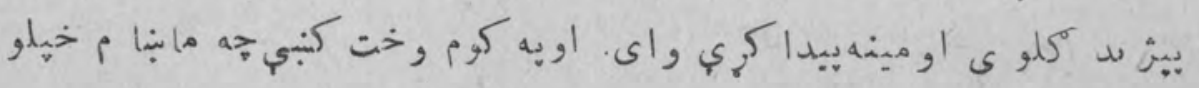




\section{(ret)}

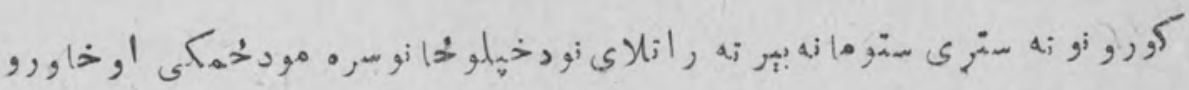

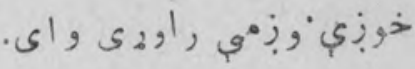

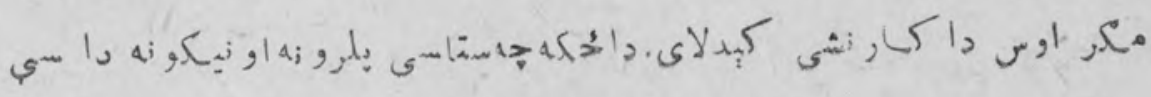

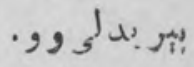

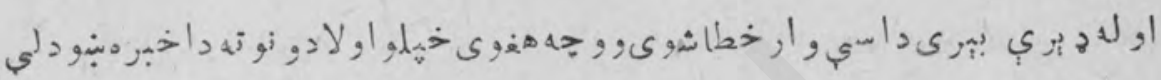

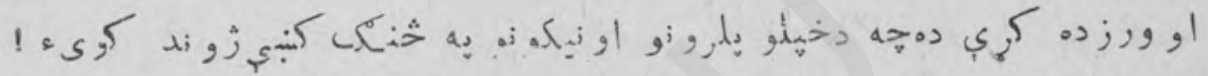

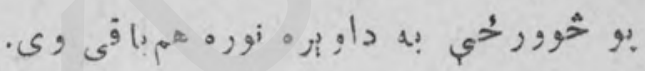

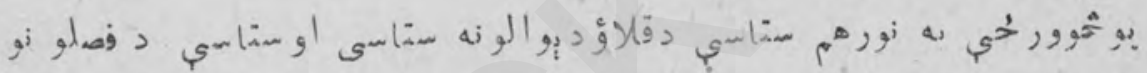

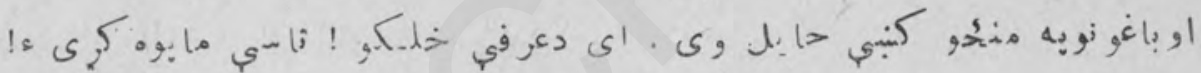

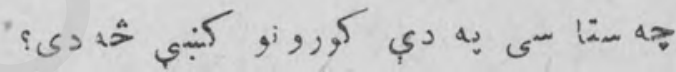

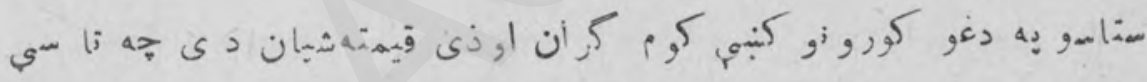

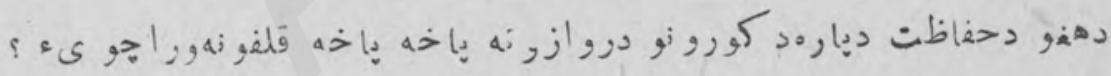

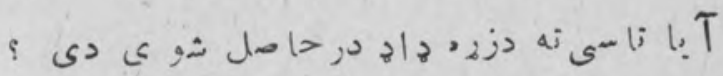

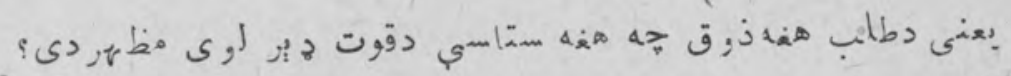

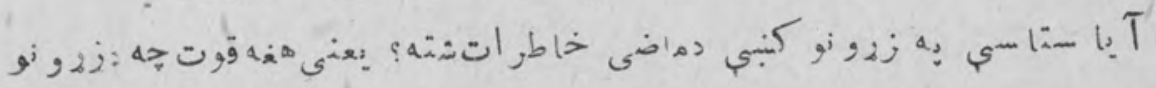

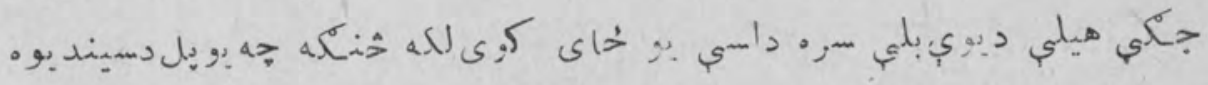

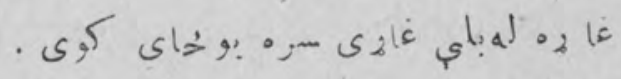

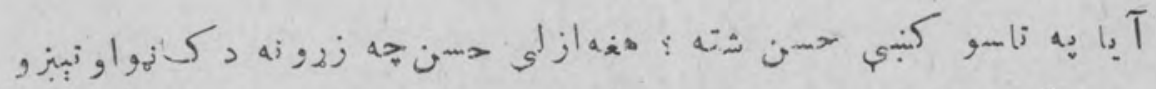

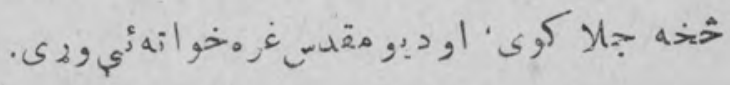

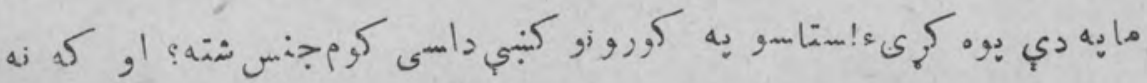




\section{$4+4$}

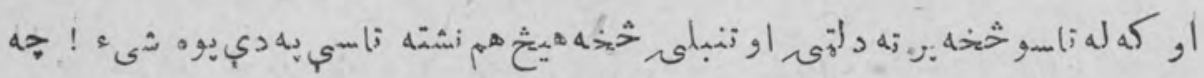

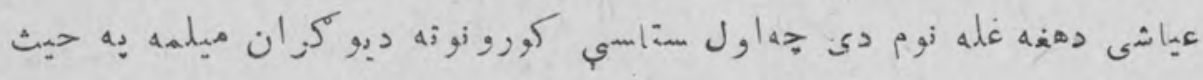

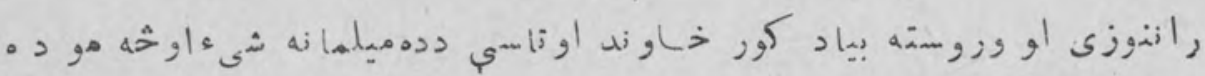

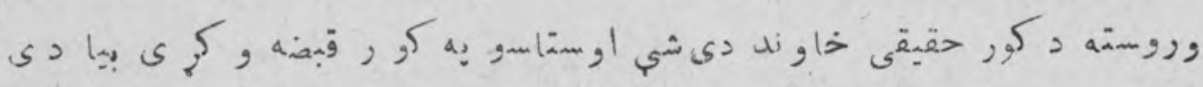

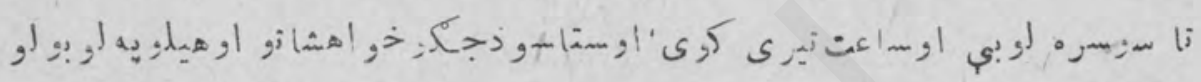

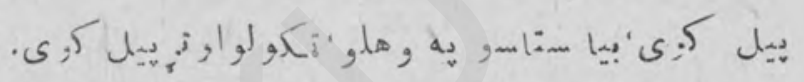

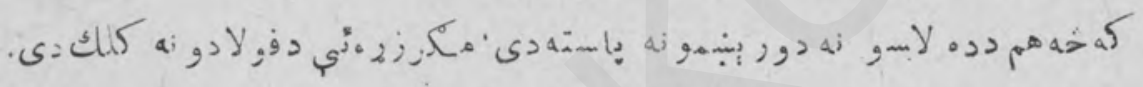

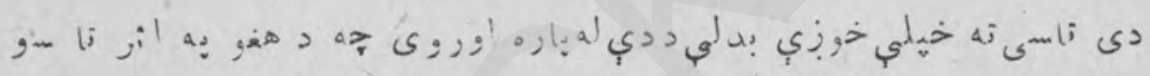

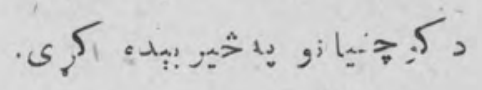

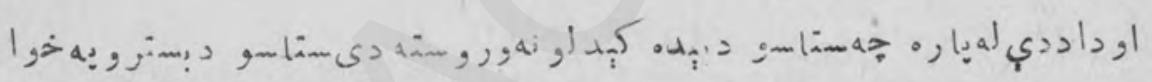

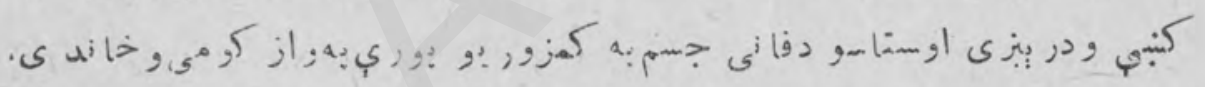

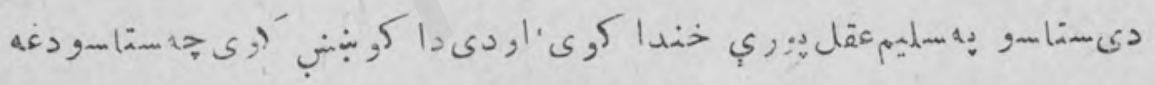

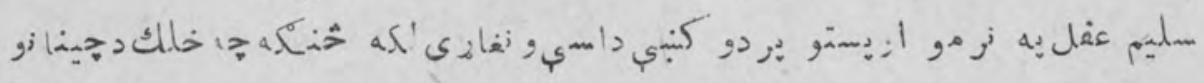

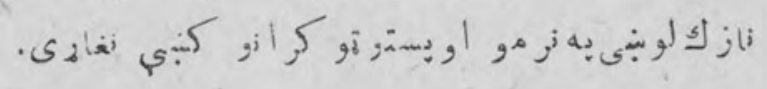

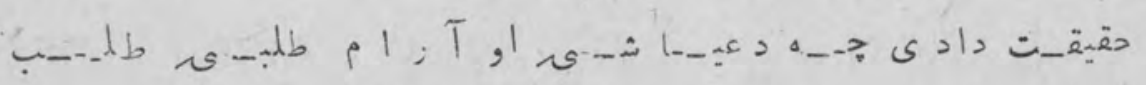

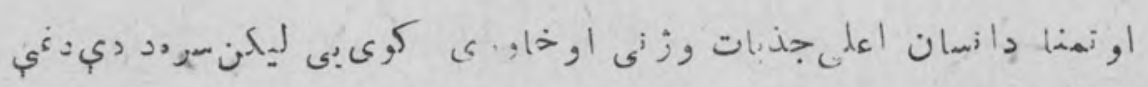

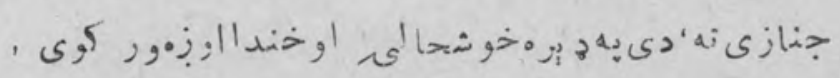

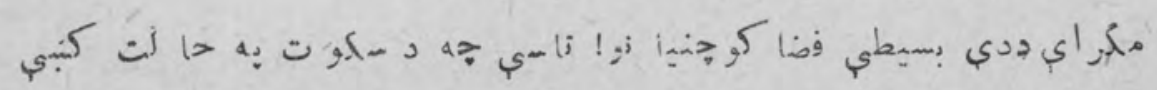

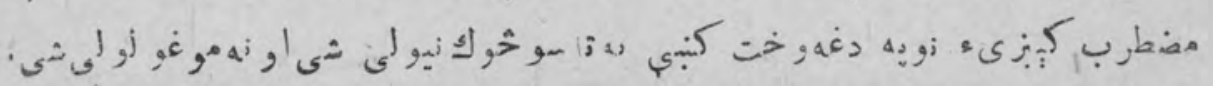

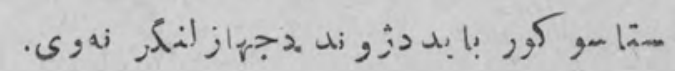




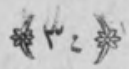

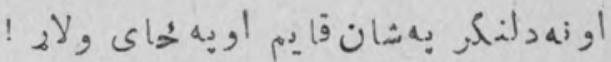

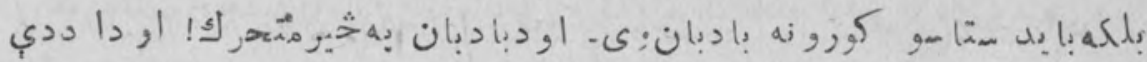

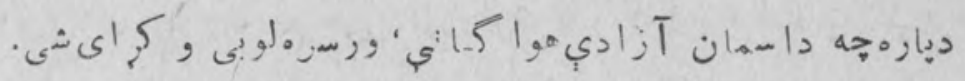

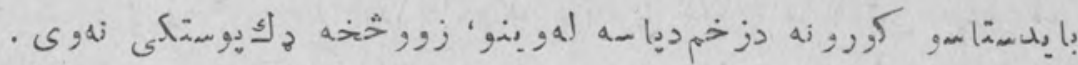

·

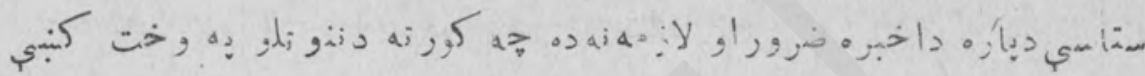

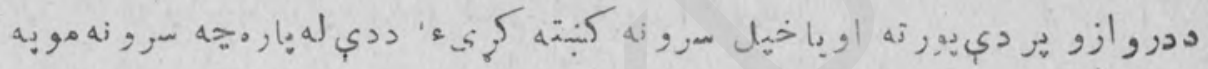

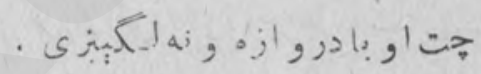

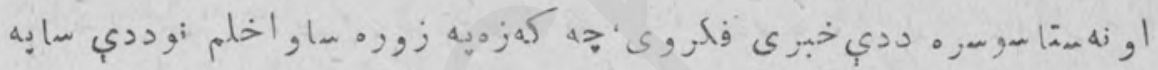

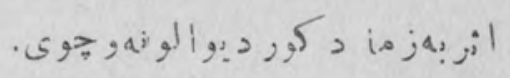

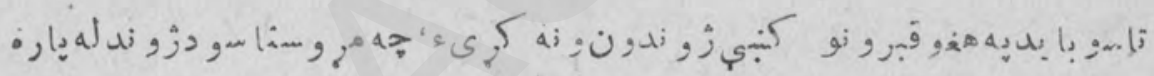

$$
\text { - . }
$$

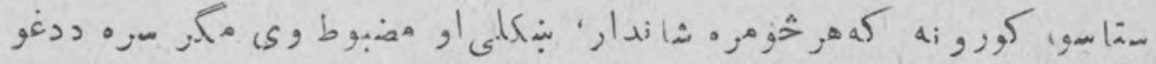

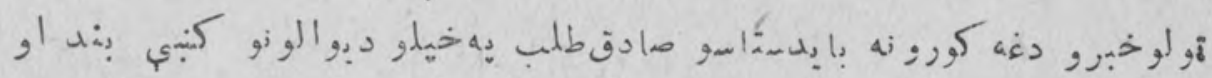
.

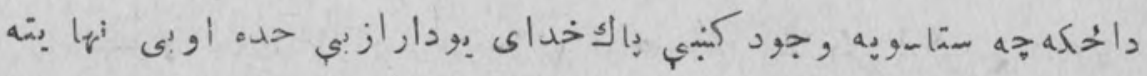

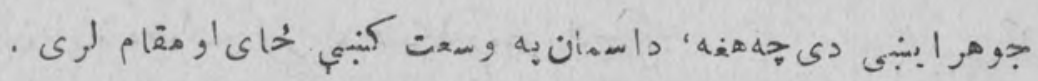

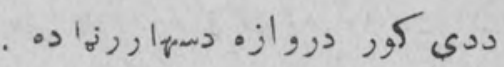

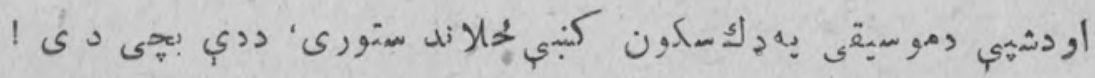




\section{mo}

$$
-1 \cdot-
$$

بيا بوهجولا وروبل:

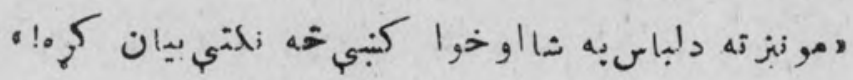

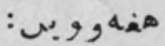

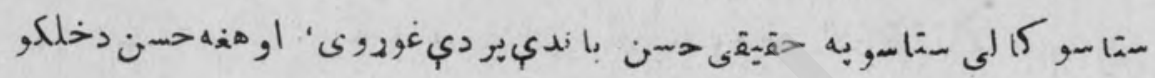
له نظرخ خذه نتخو وث.

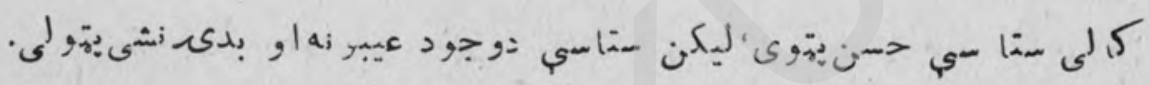

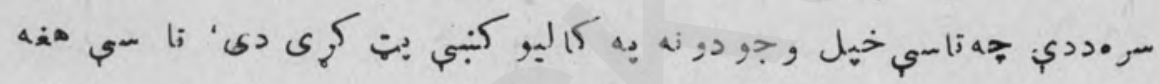

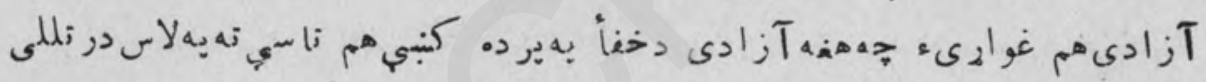

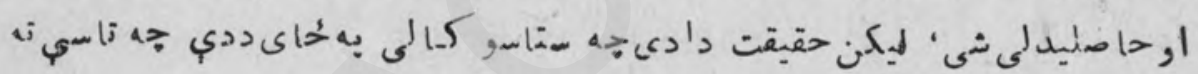

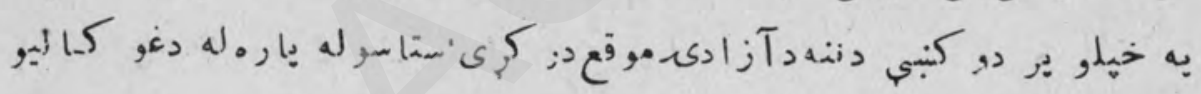

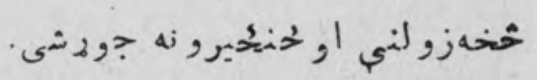

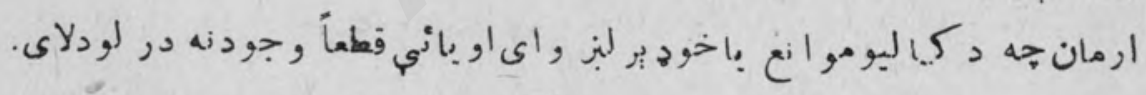

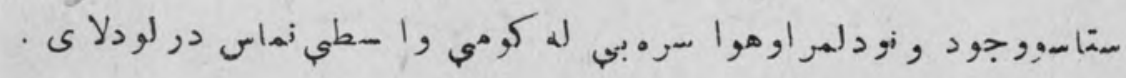

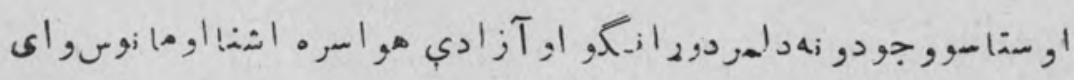

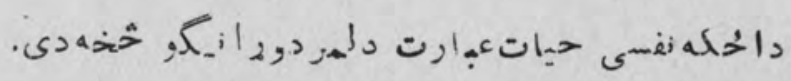

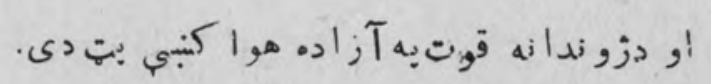

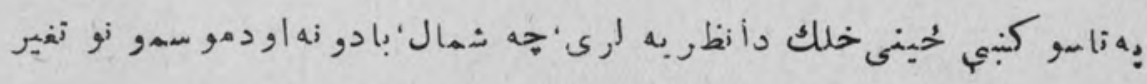

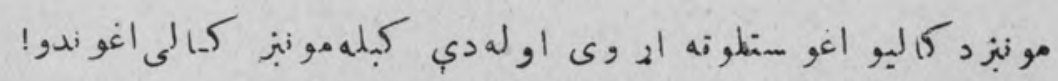

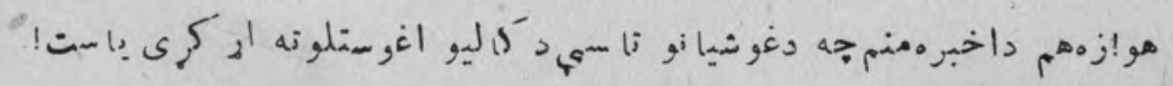




\section{(4)}

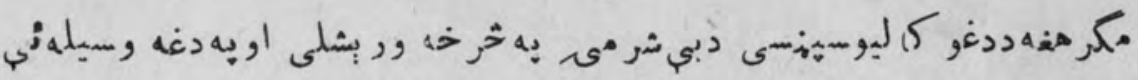

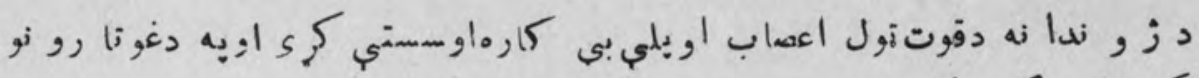

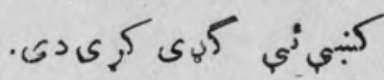

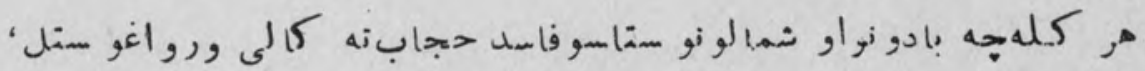
نوهذه

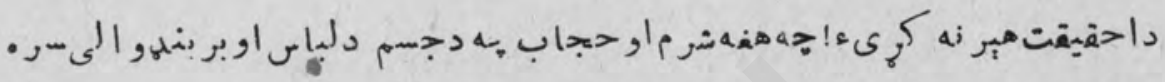

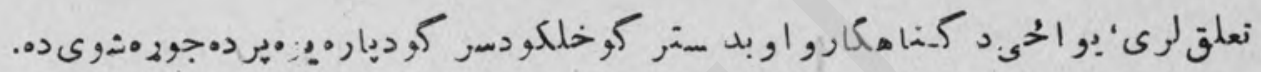

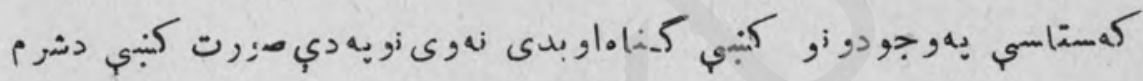

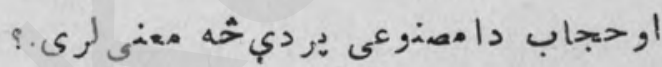

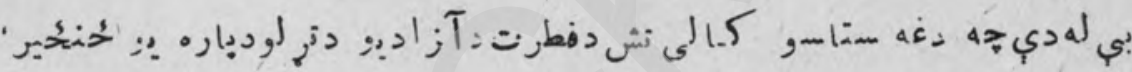

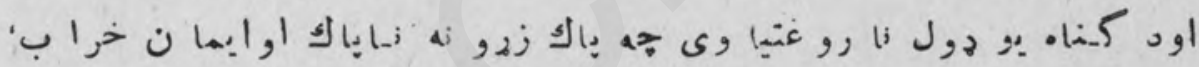

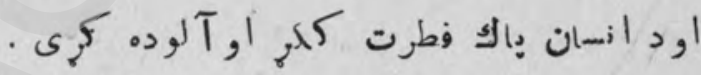

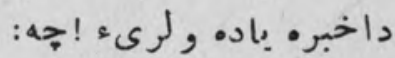

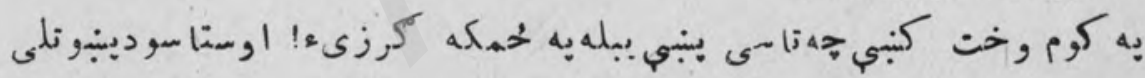

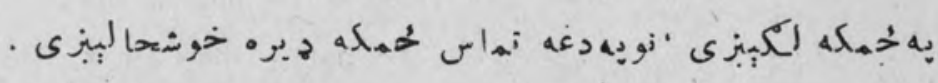

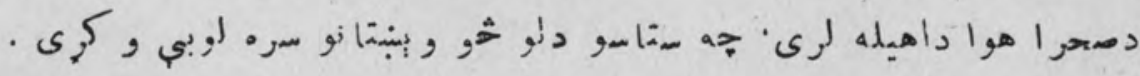
$-11$.

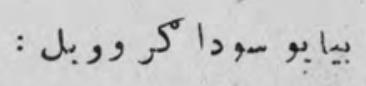

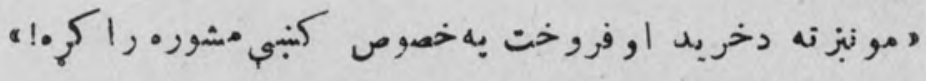

$$
\text { هاهن ورنه }
$$

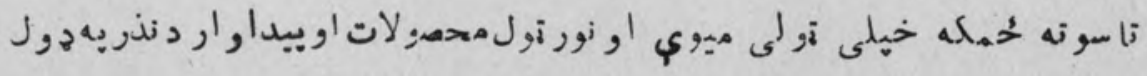




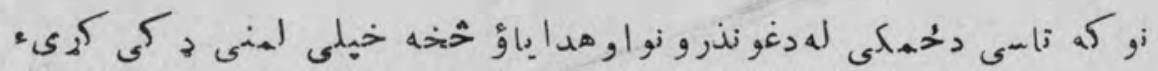

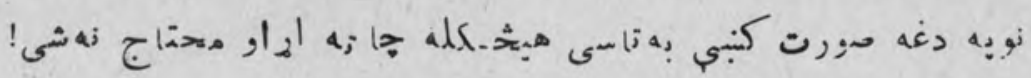

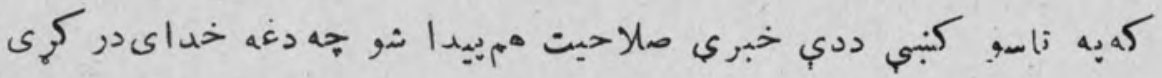

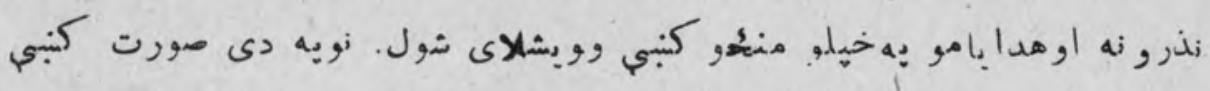

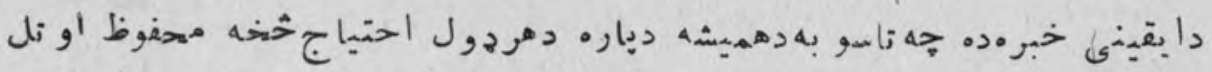

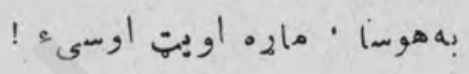

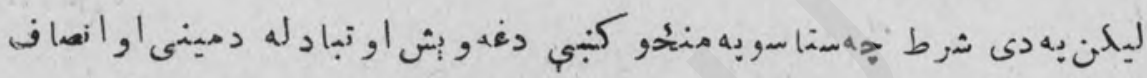

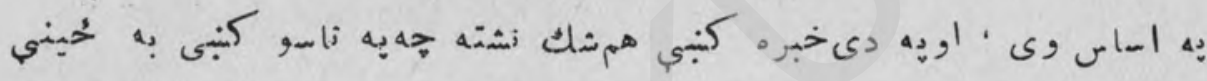

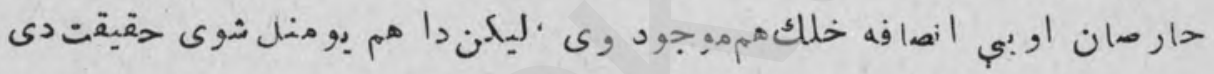

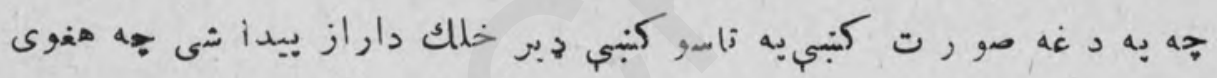

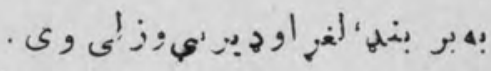

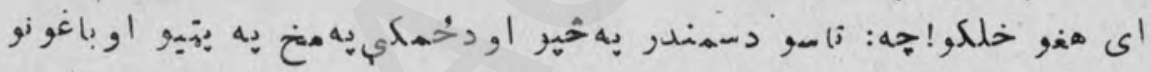

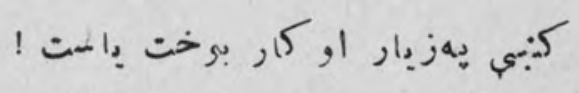

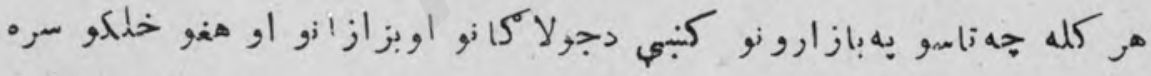

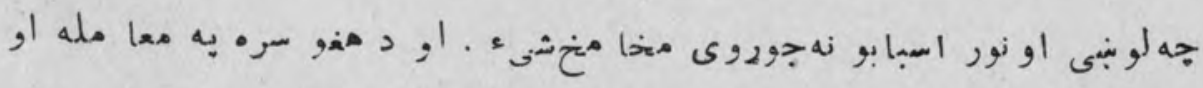

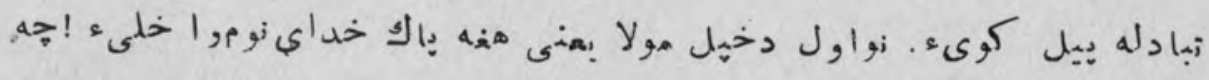

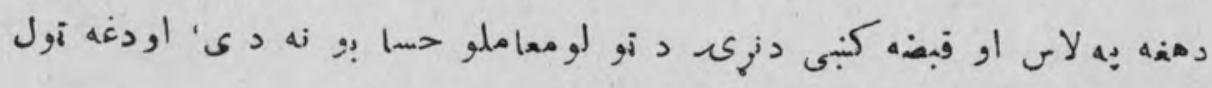

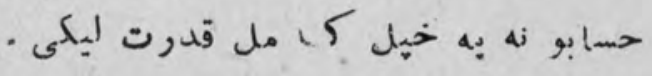

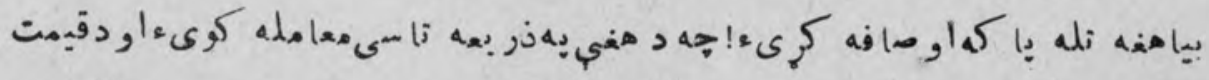

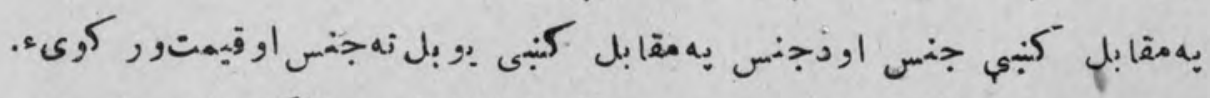

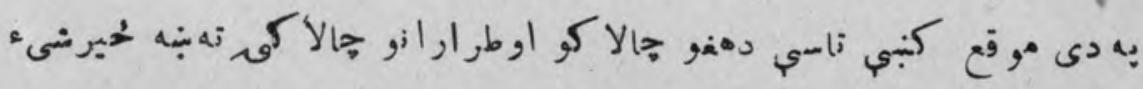




\section{ณ人}

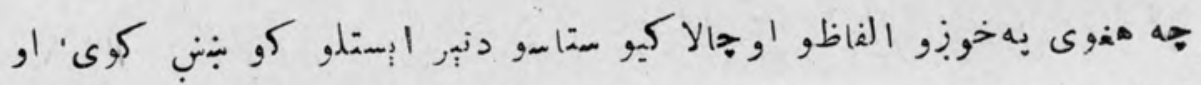

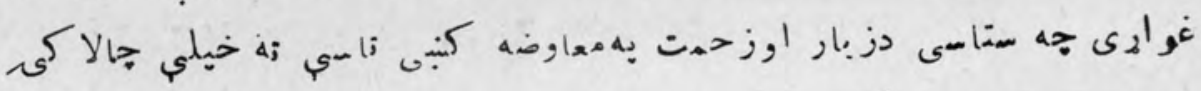

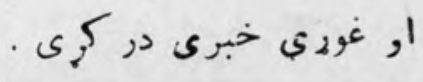

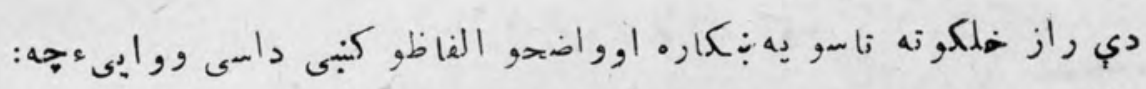

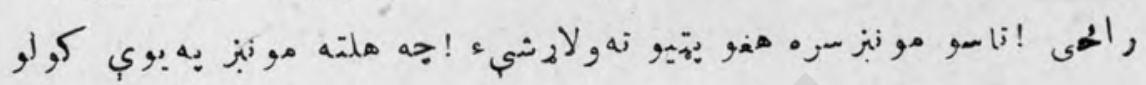

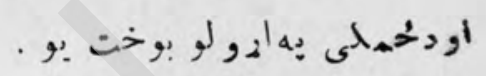

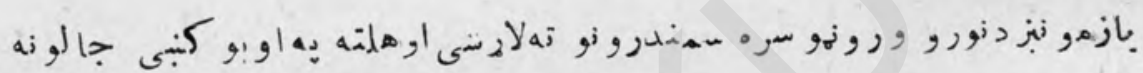

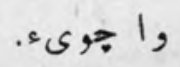

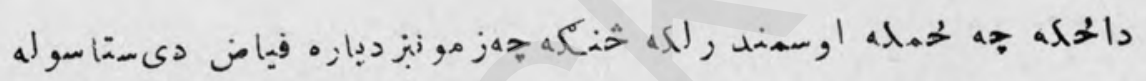

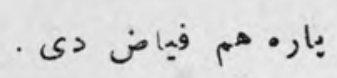

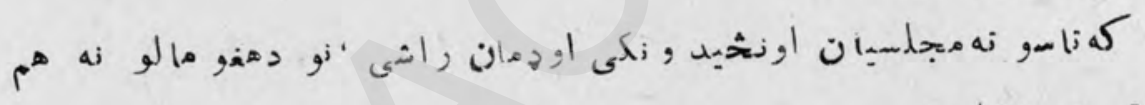

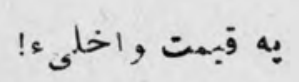

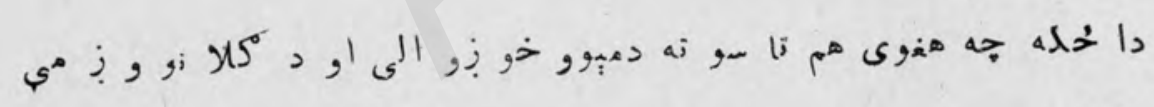
رارئ .

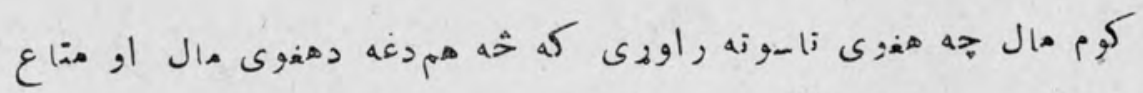

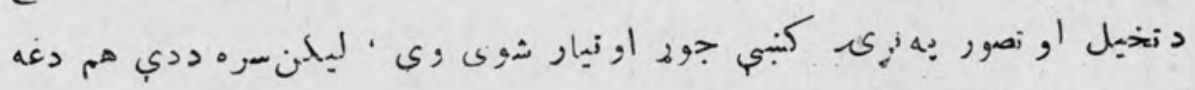

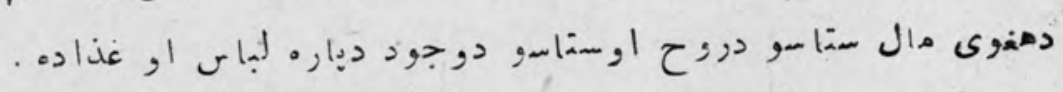

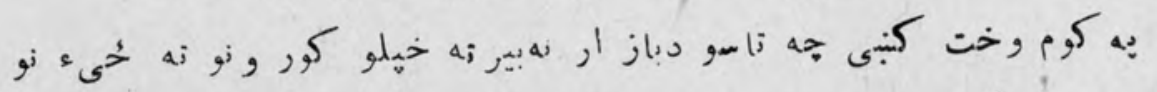

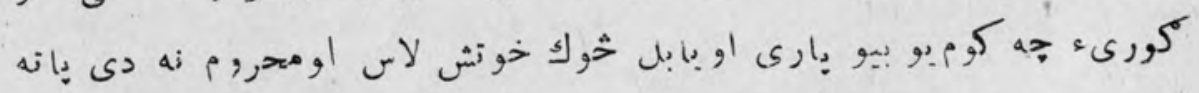
شوى .

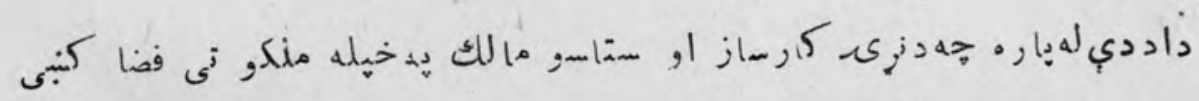




\section{$\therefore \cdot$}

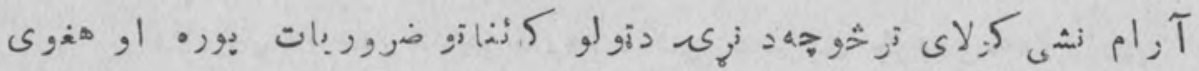
: $-i b-$

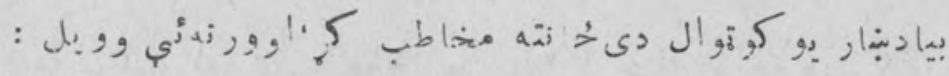

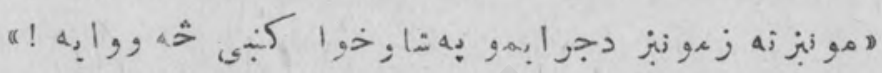
: ل, d,

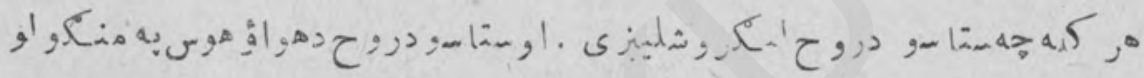

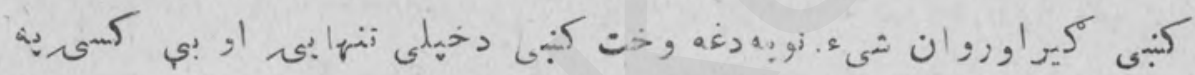

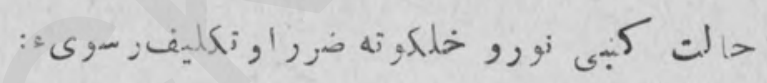

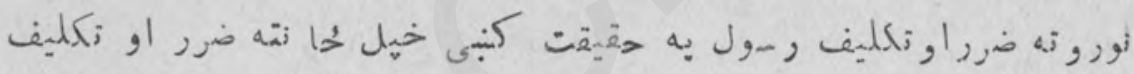

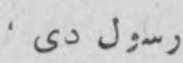

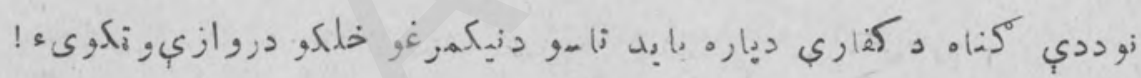
اودهغو انتظظار وباسئ

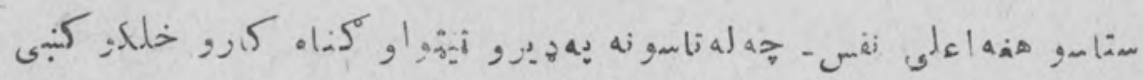

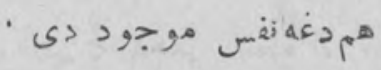

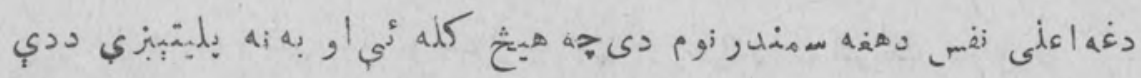

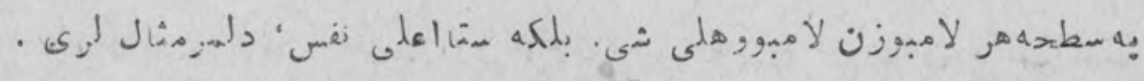

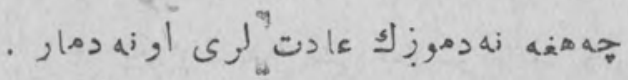

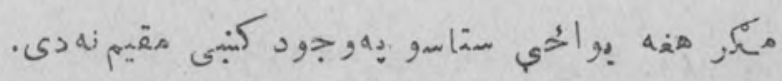

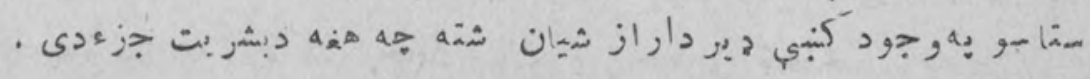

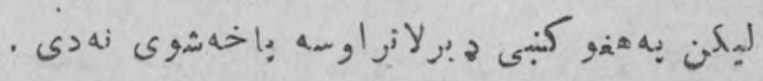




\section{(1)}

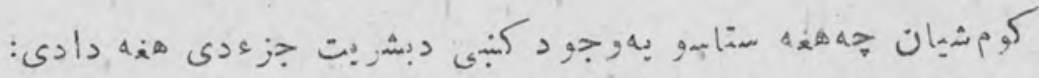

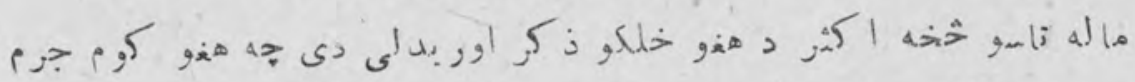

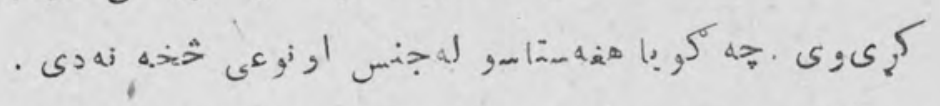

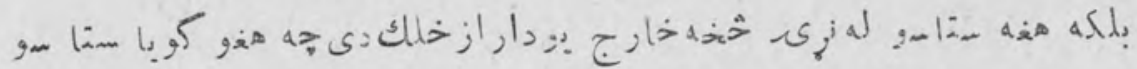

$$
\text { . } 0.25 \text { S }
$$

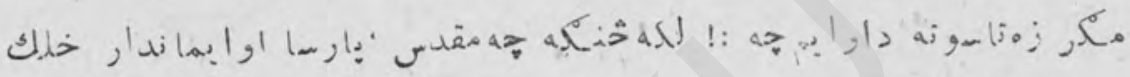

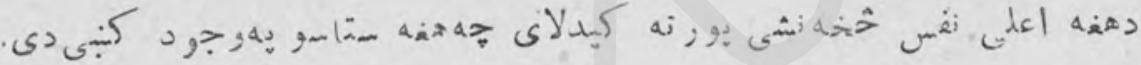
ناخ

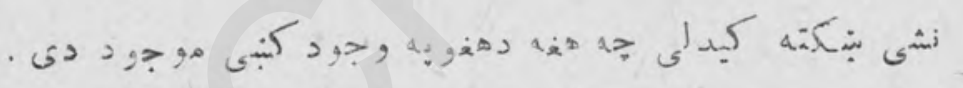

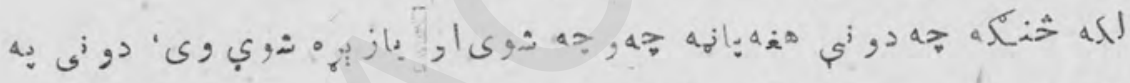

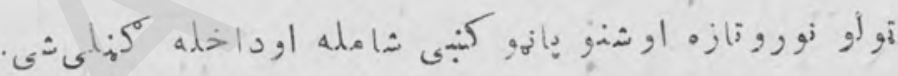

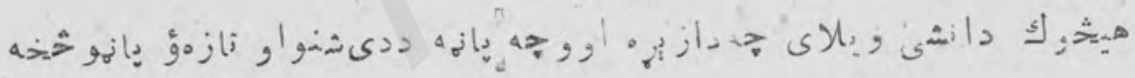

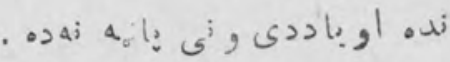
به

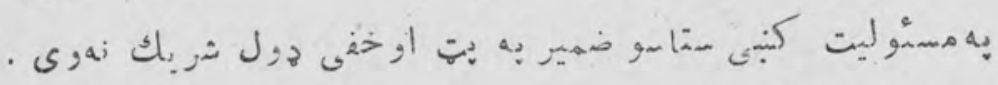

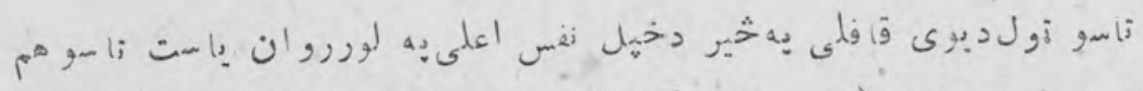

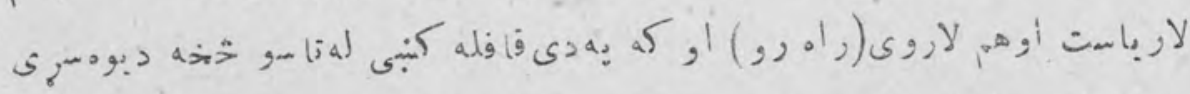

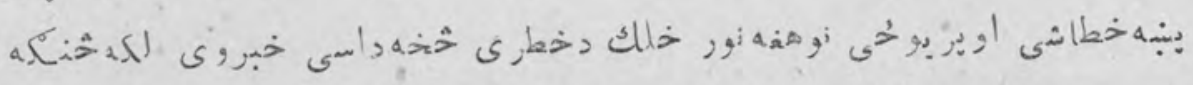

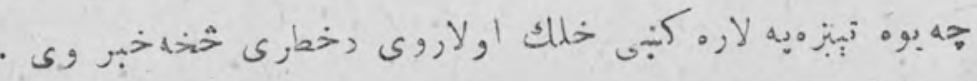

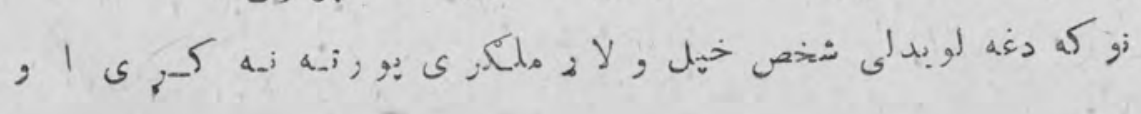




\section{(1)}

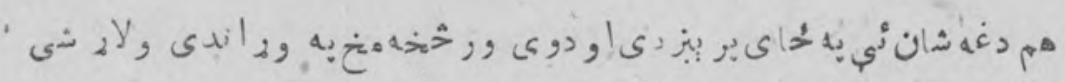

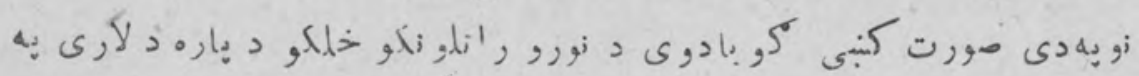

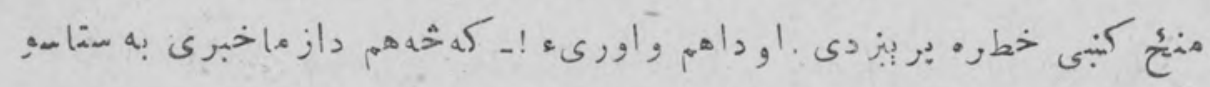

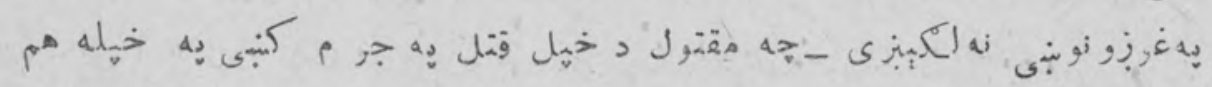

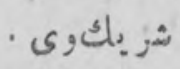

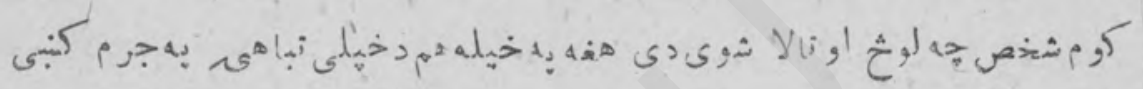
شر بك دى . مان.

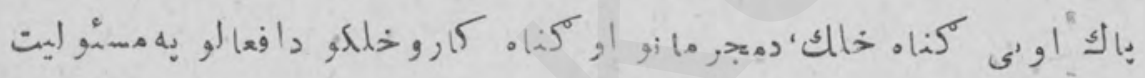

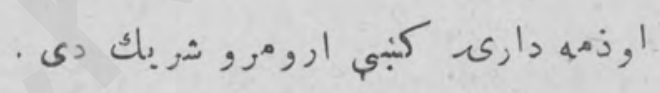

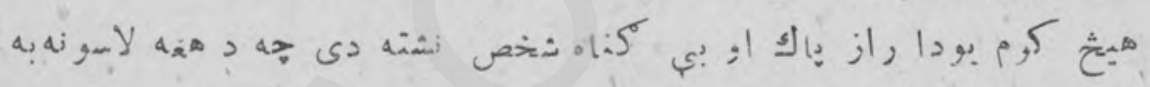

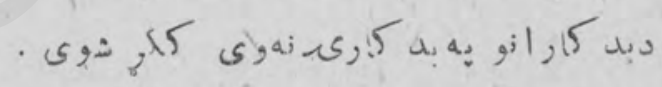

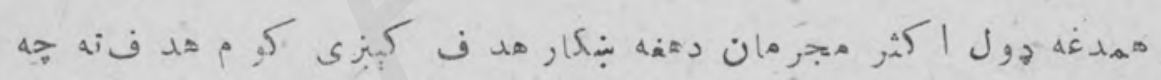

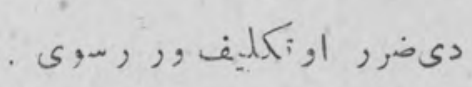

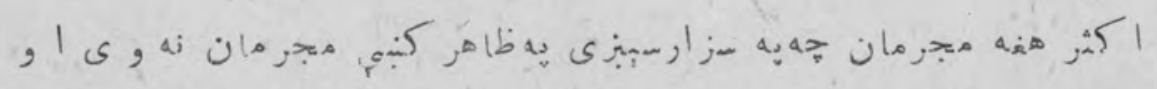

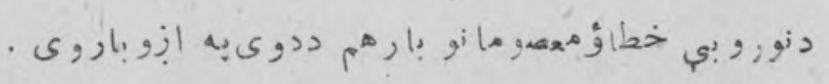

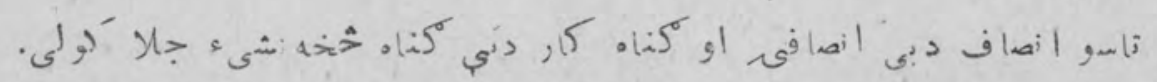

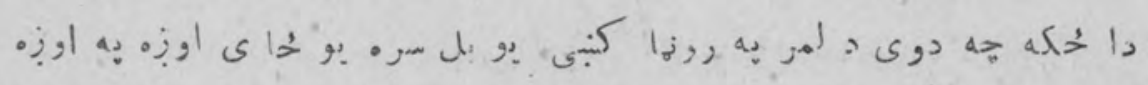
(s) 2. ,

|

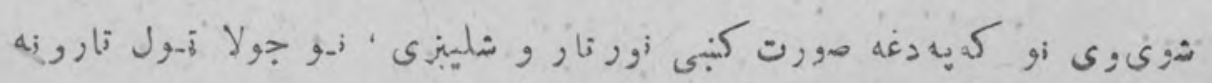




\section{$\langle\leqslant\rangle$}

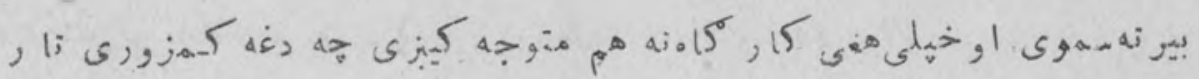

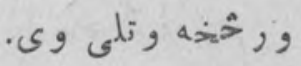

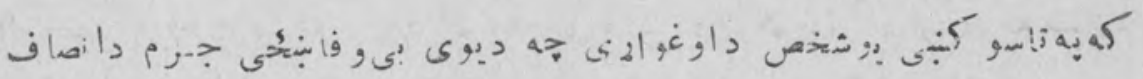

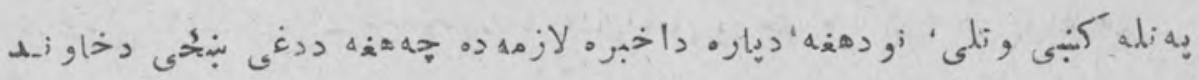

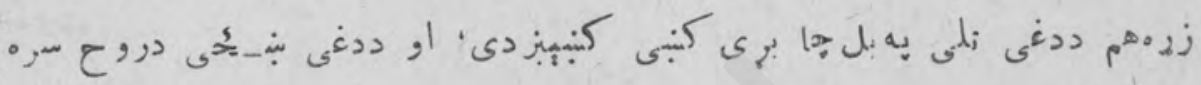

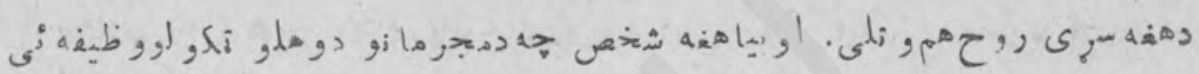

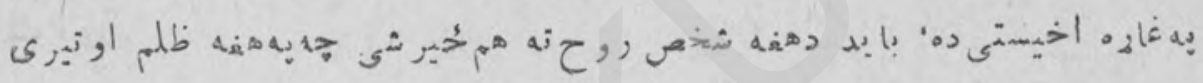
(4)

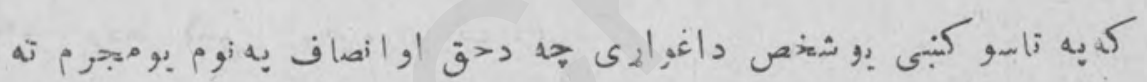

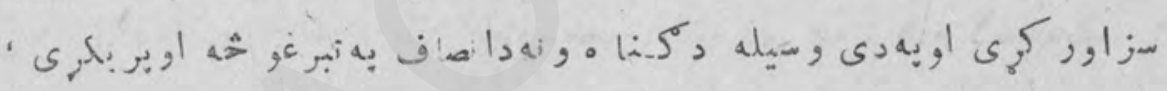

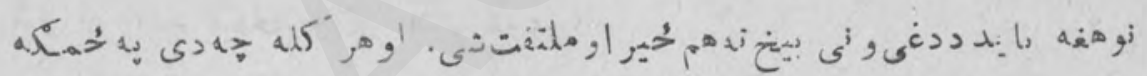

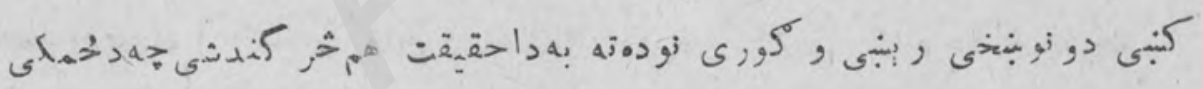

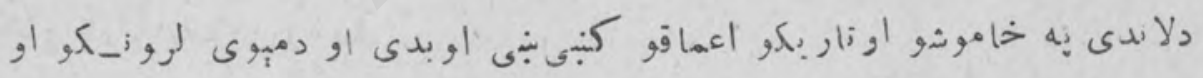

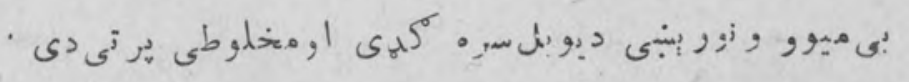

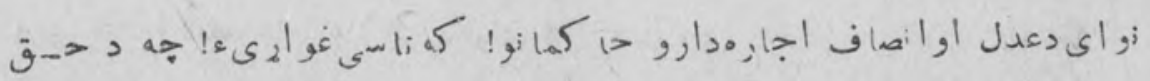

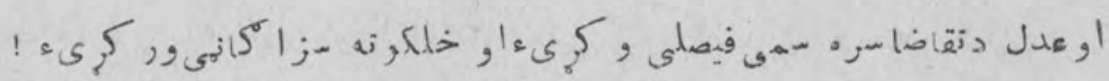

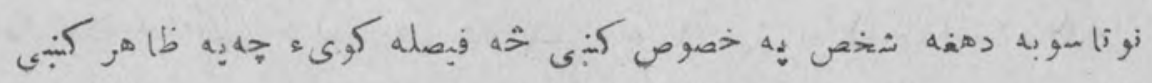

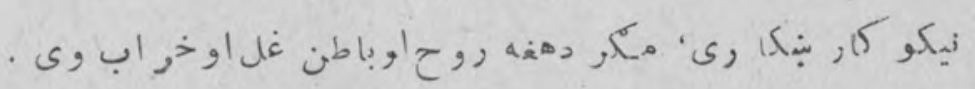

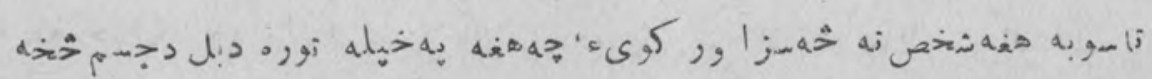
روح جلا كوى . 


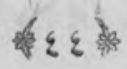

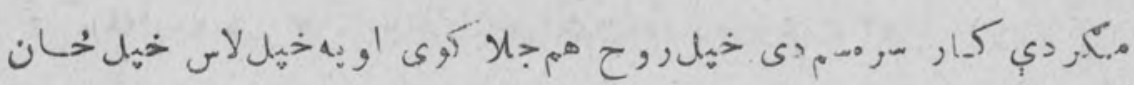

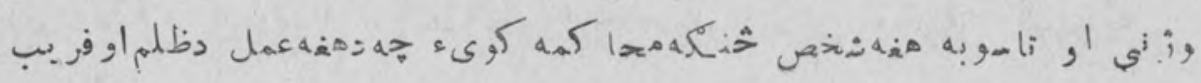

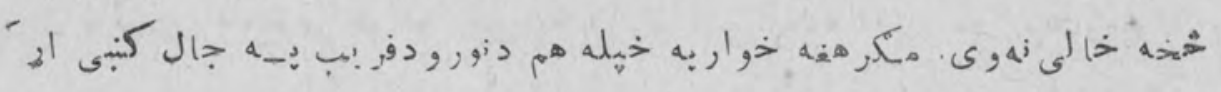

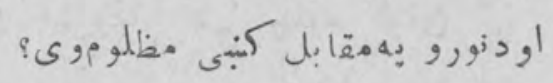

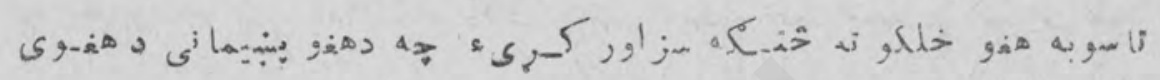

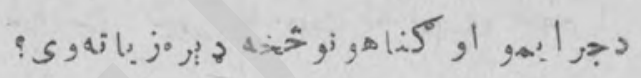

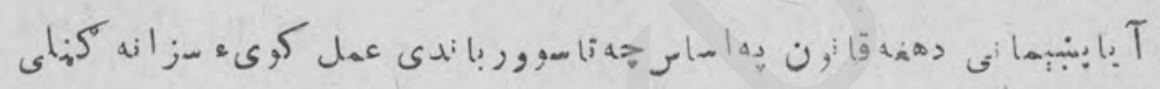
S

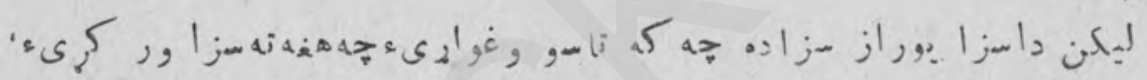

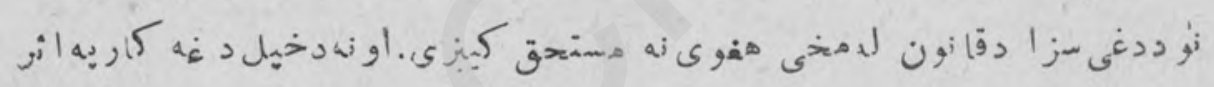

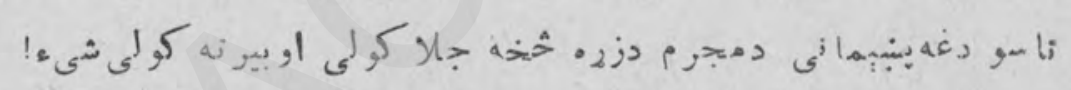

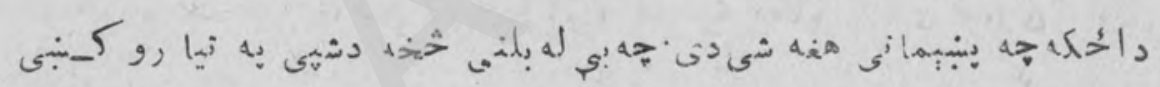

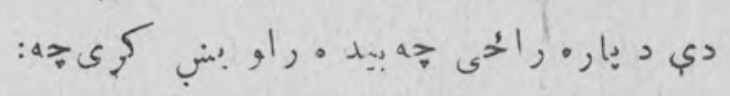

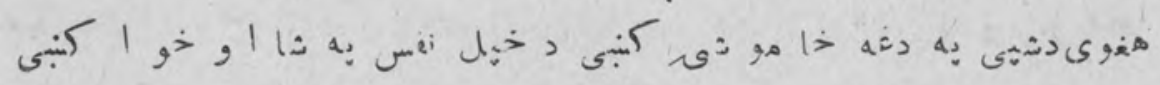
. 5 , and libes

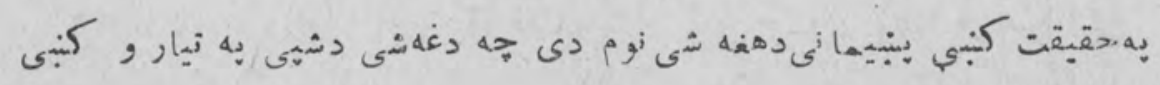

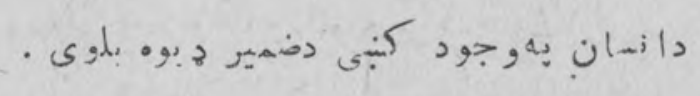

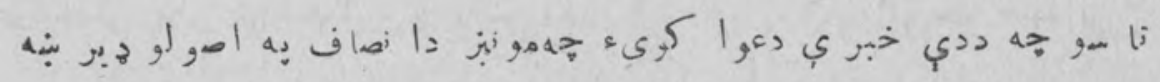

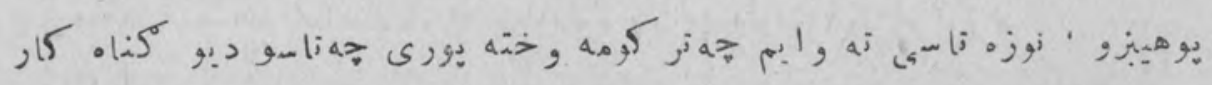

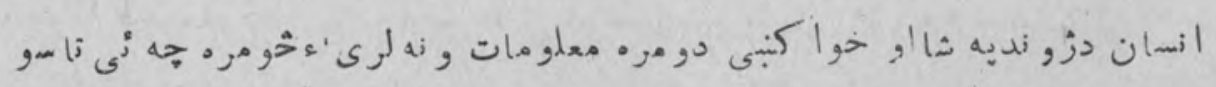

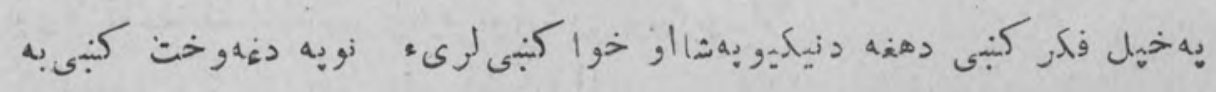




\section{络}

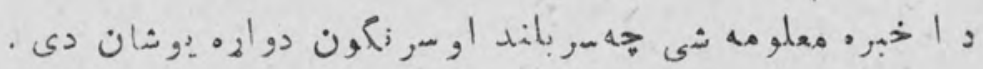

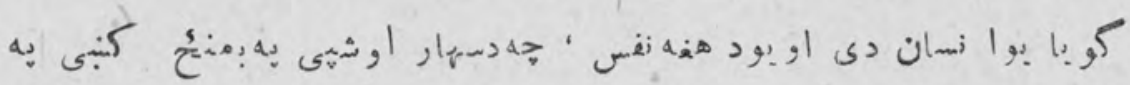

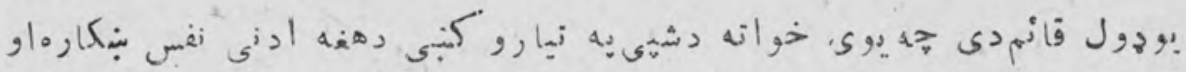

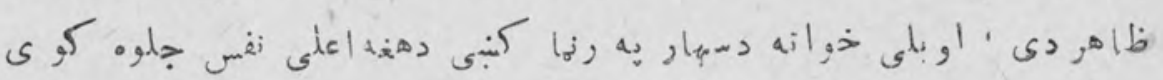

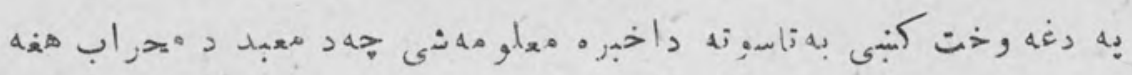

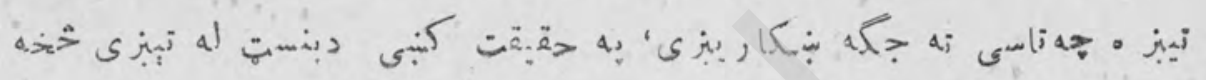

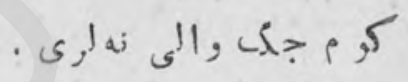

$-18$.

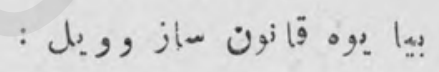

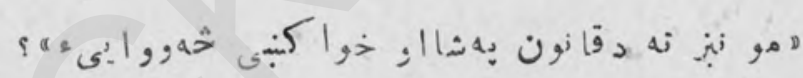
:

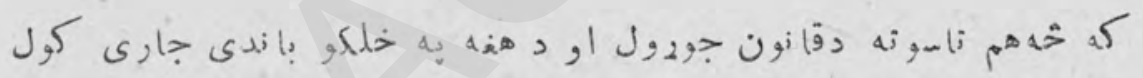

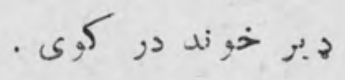

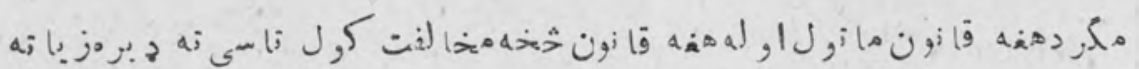

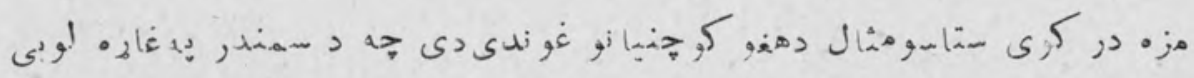

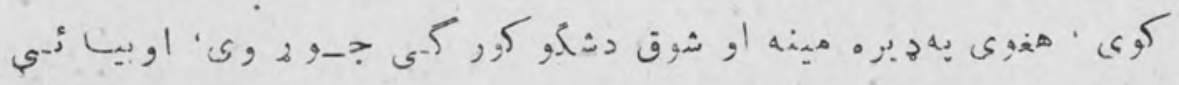

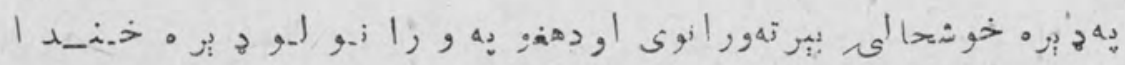

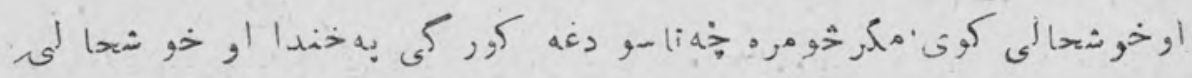

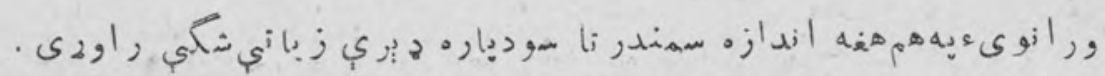

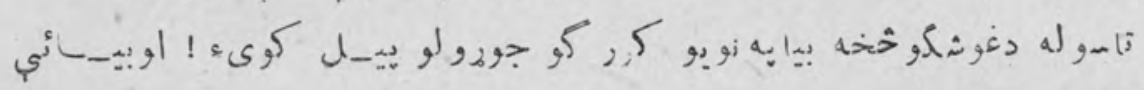

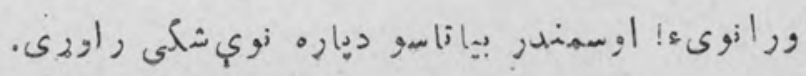




\section{$4: 4$}

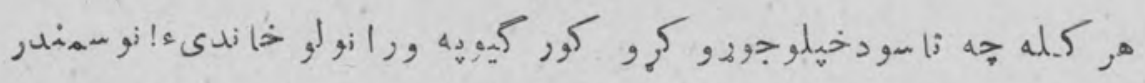

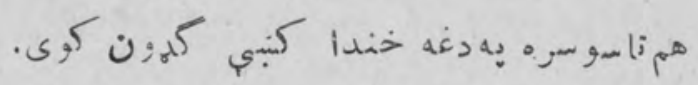

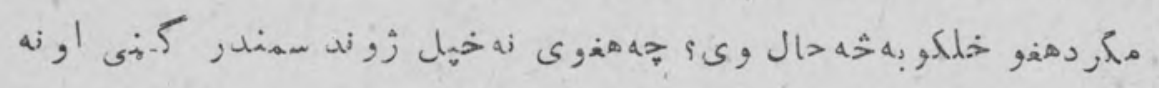

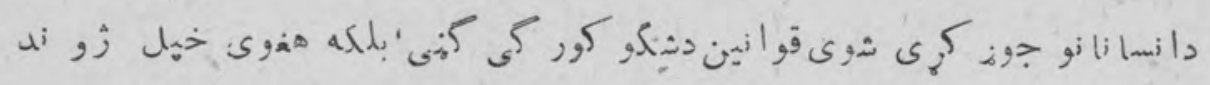

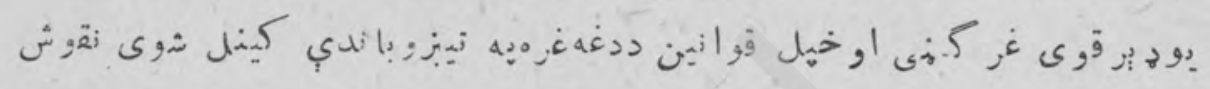

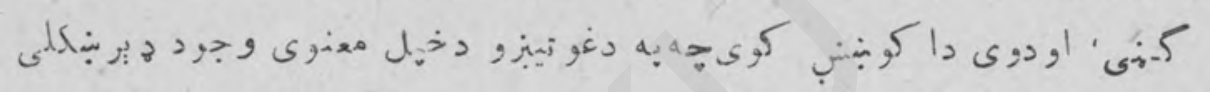

$$
\text { 'نقوش و كينى ' }
$$

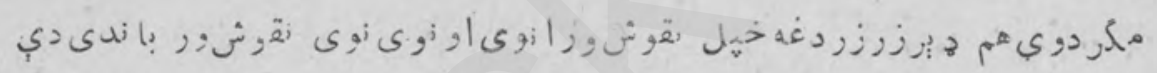

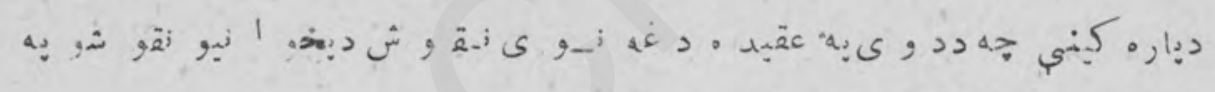

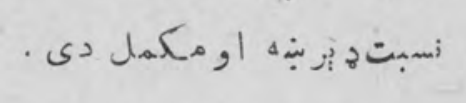

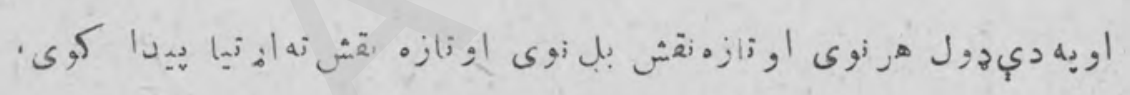

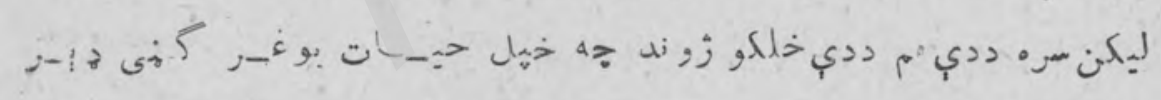
.

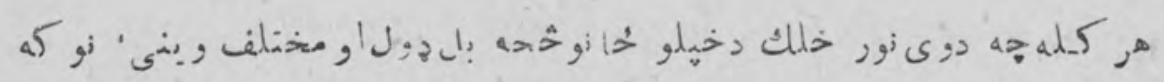

$$
\text { حه }
$$

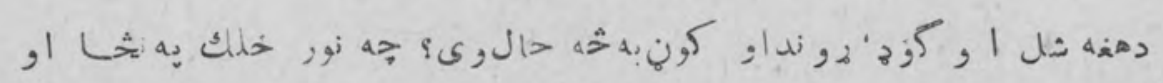

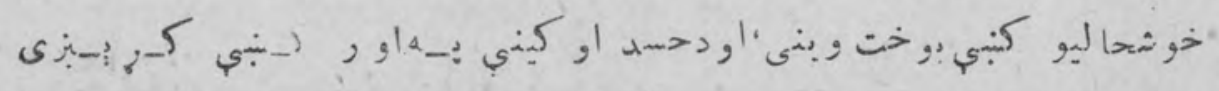

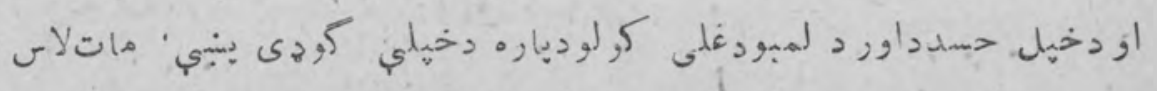

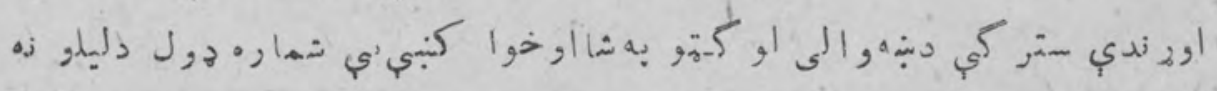
. 


\section{(2)}

هدى

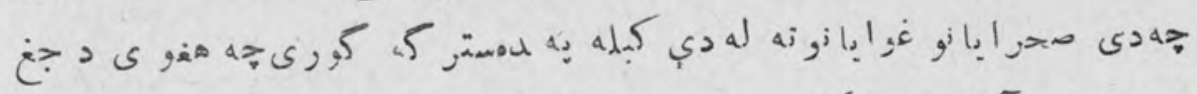

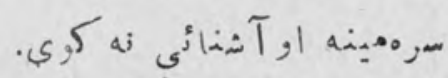

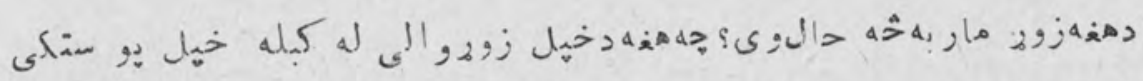

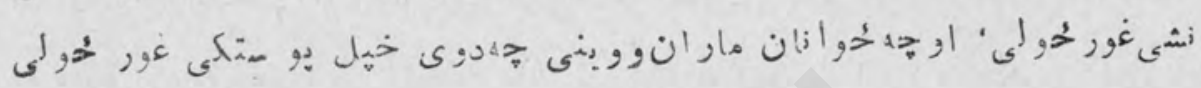

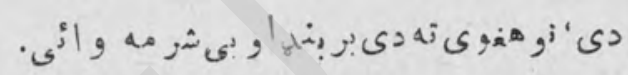

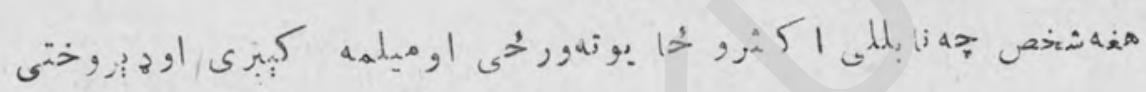

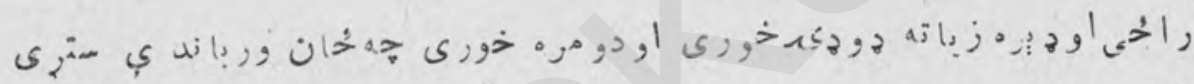

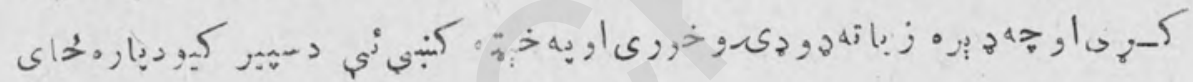

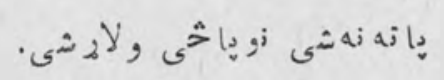

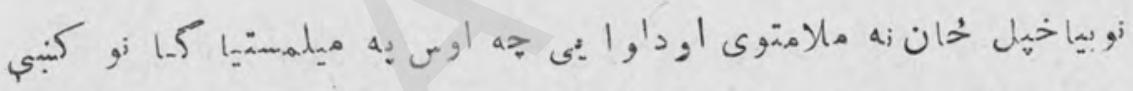

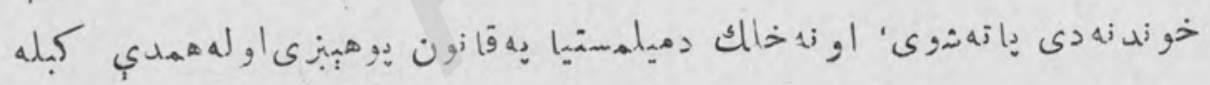

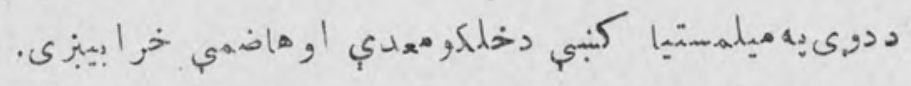

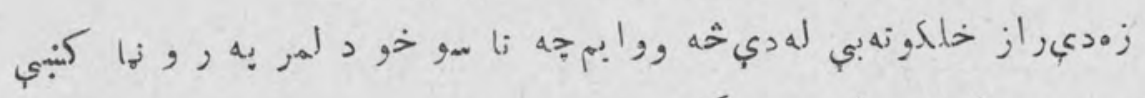

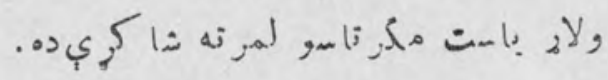

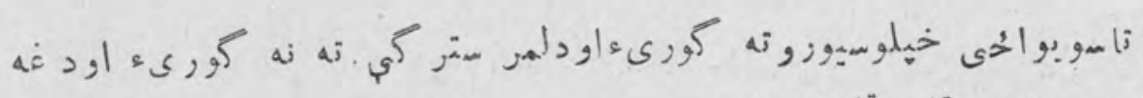

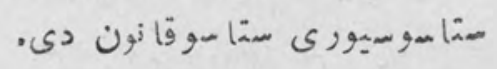

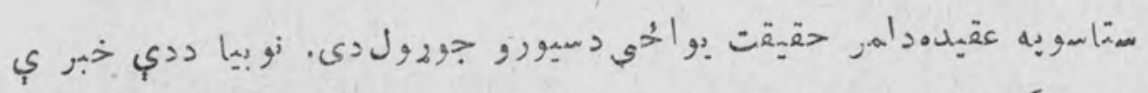

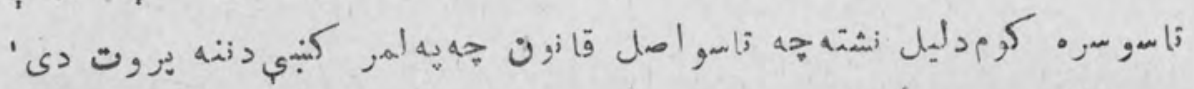

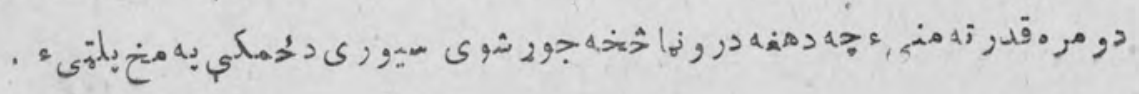




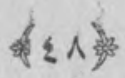

$$
\text { - }
$$

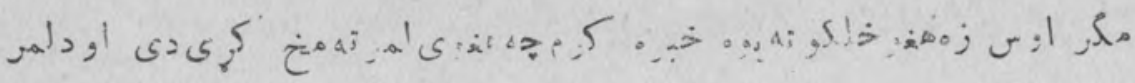

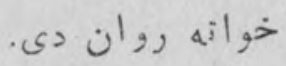

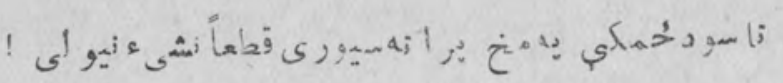

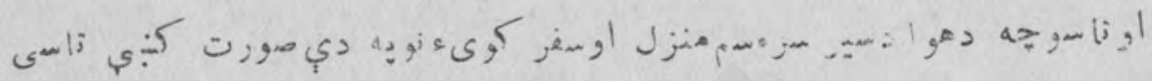

$$
\therefore \text { S J }
$$

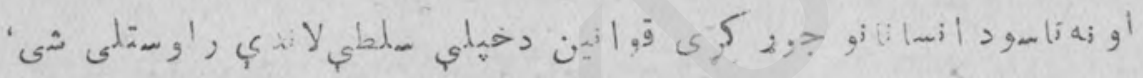

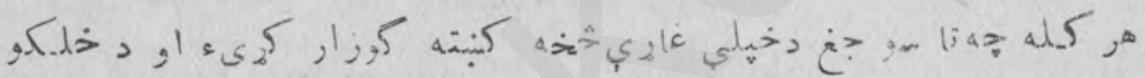

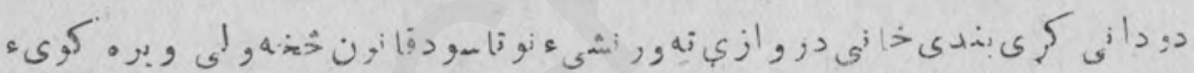

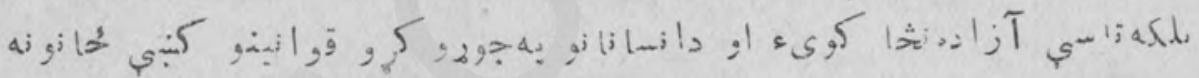
!

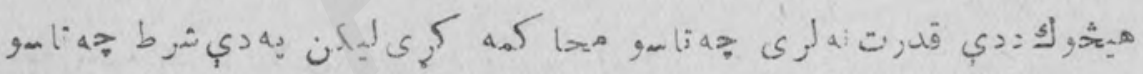

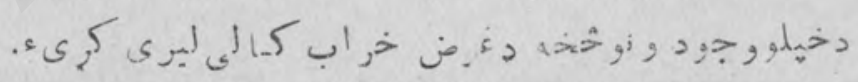

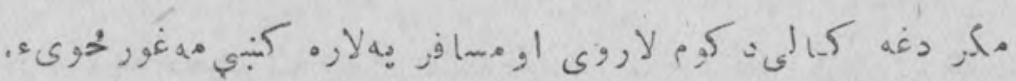

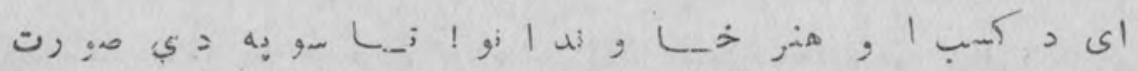

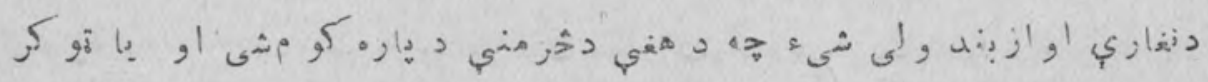

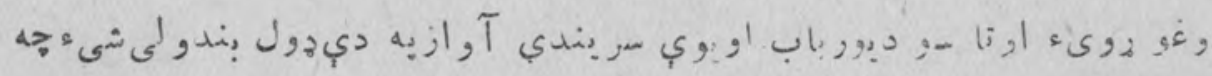

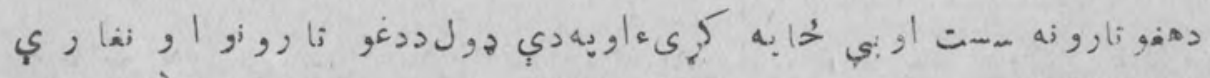

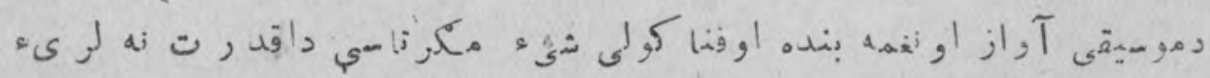

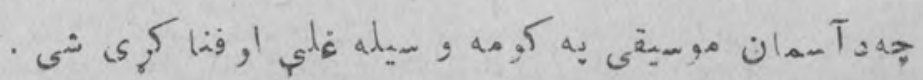




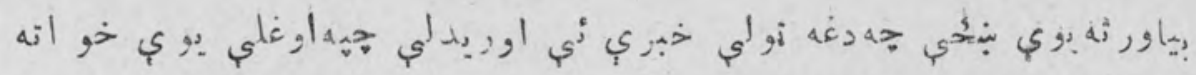
ولاءمو.,وب.ل :

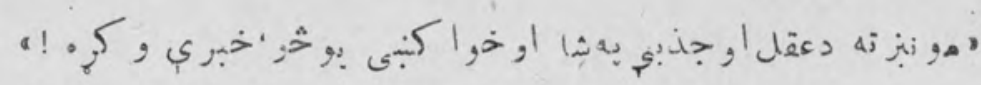
: ه

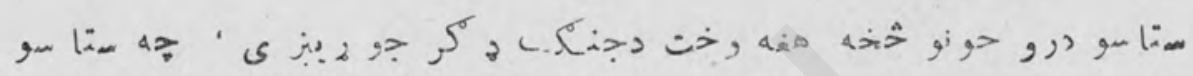

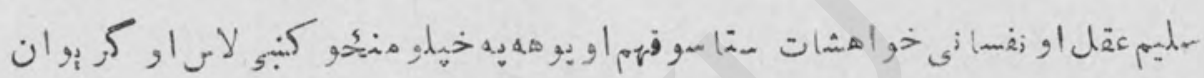

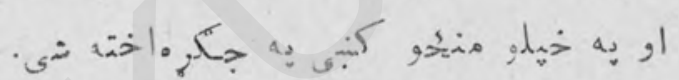

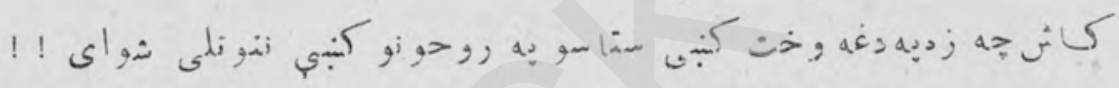

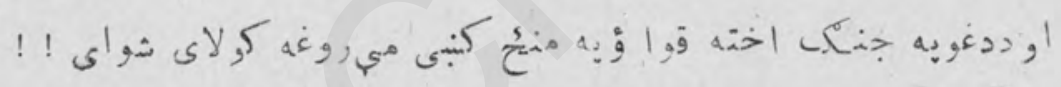

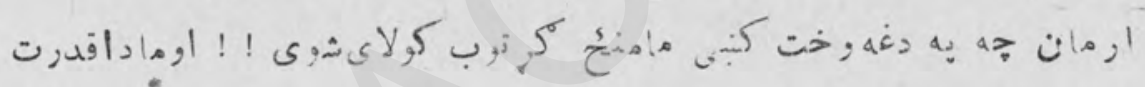

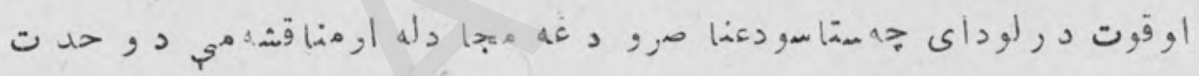

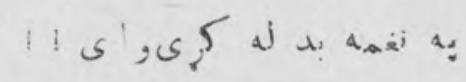

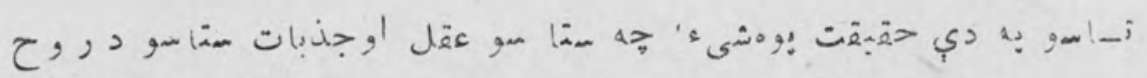

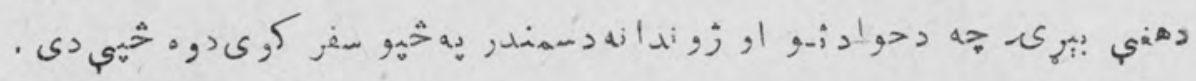

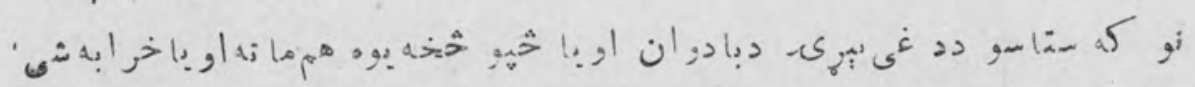

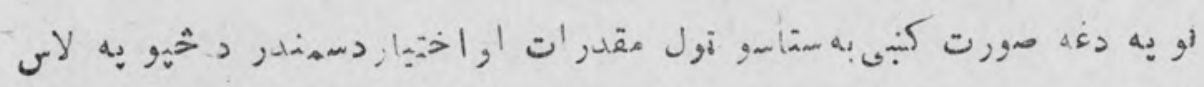

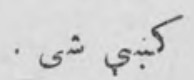

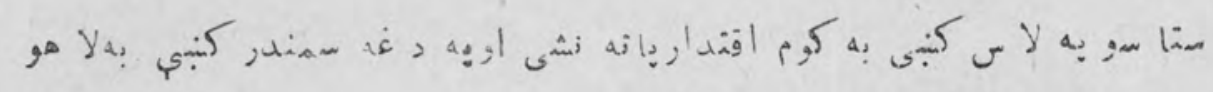
روان ب! ست !

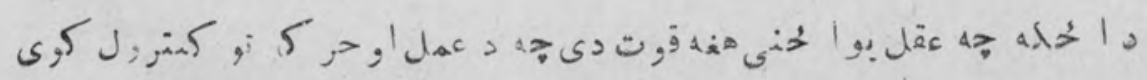




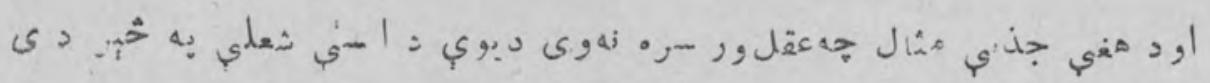

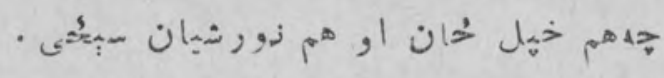

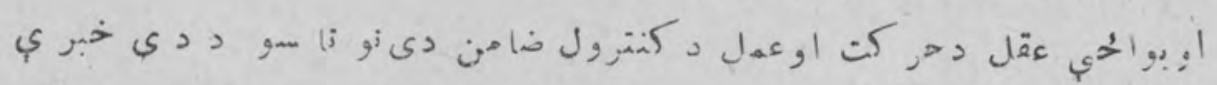

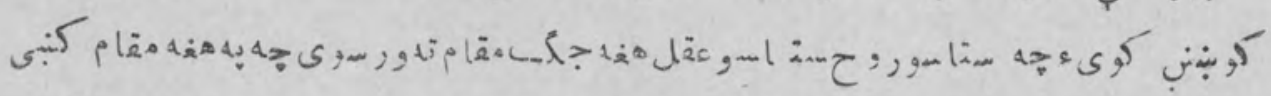

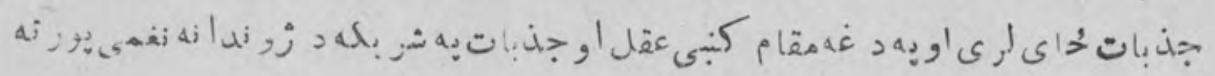

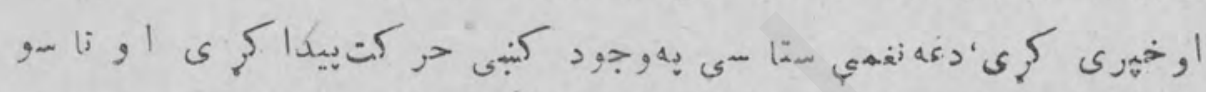

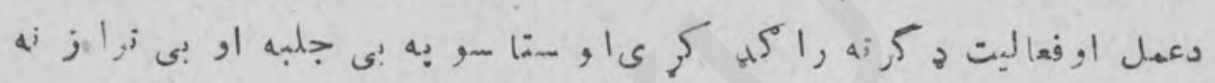

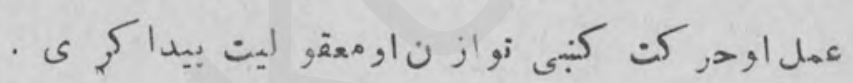

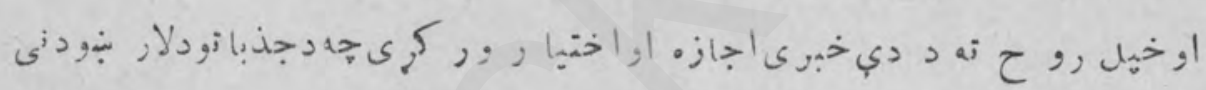

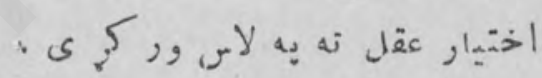

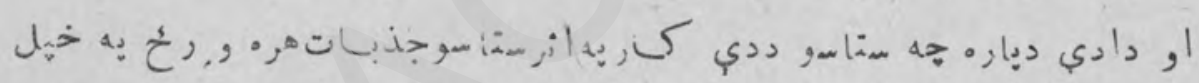

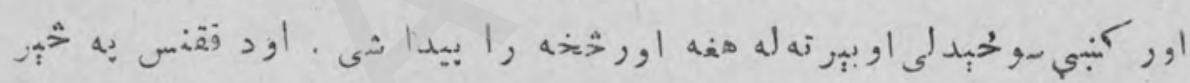

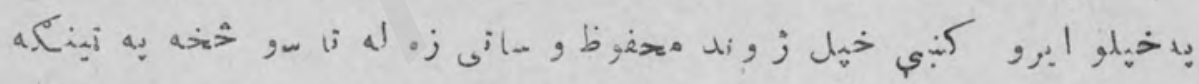

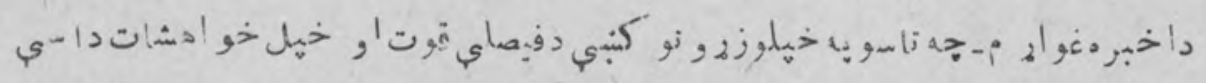

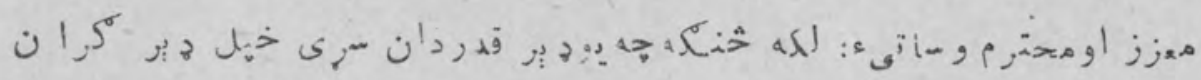

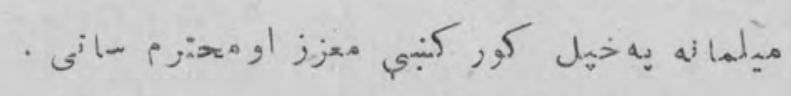

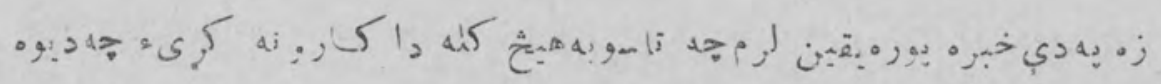

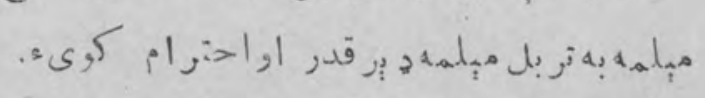

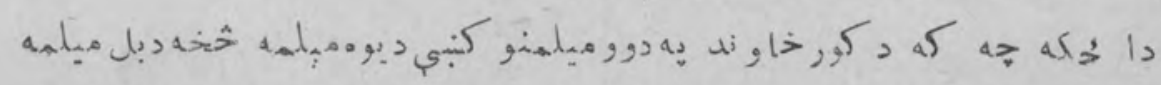

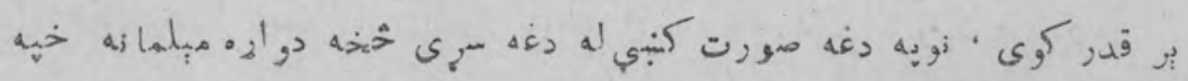

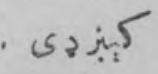




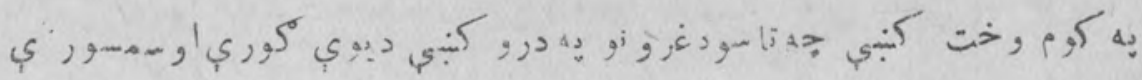

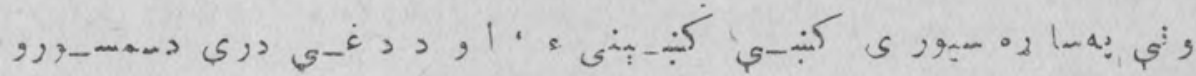

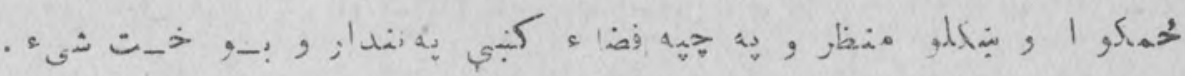

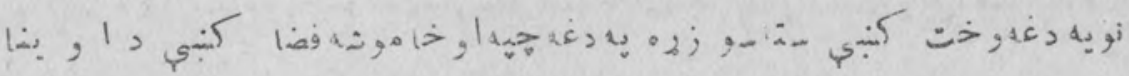
$: 43.5$

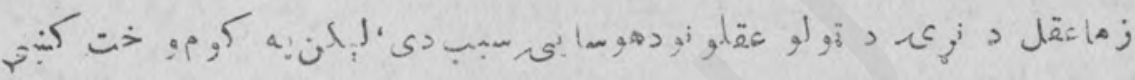

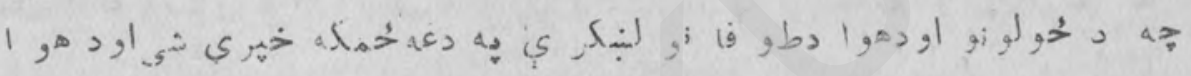

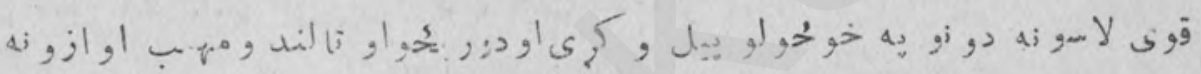

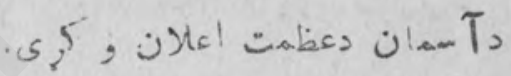

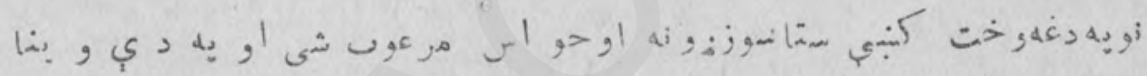
$: 5$, ,

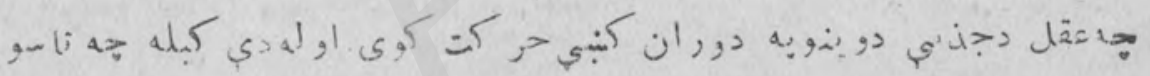

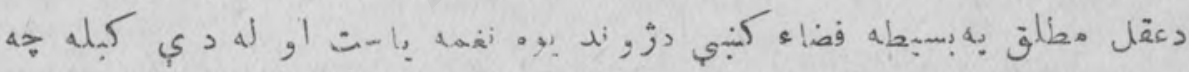

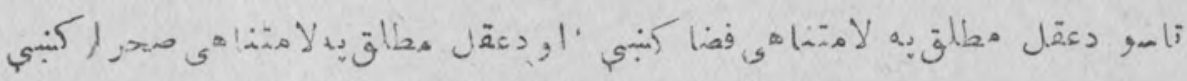

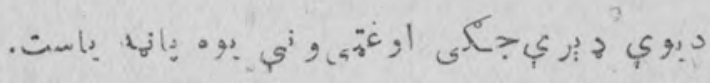

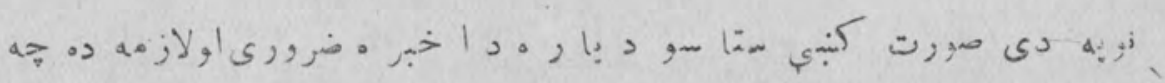

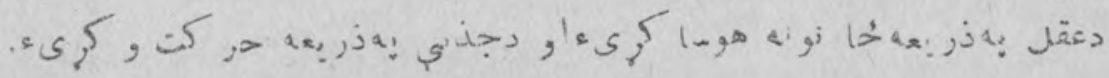
-10 .

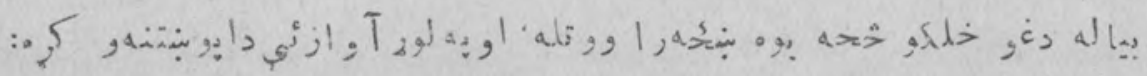

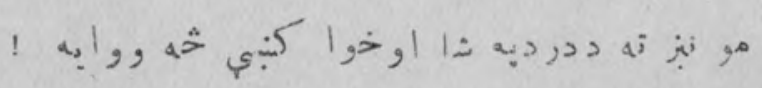




\section{(or)}

: l, , d d

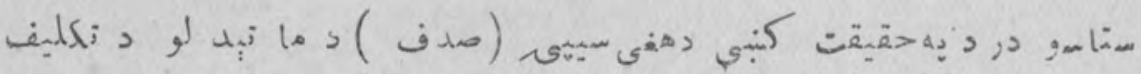

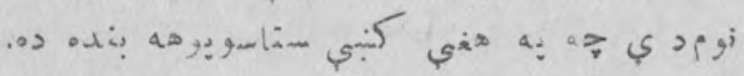

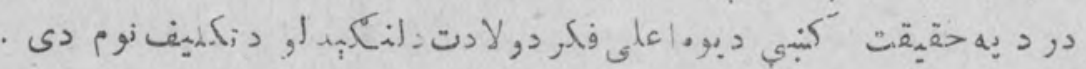
质

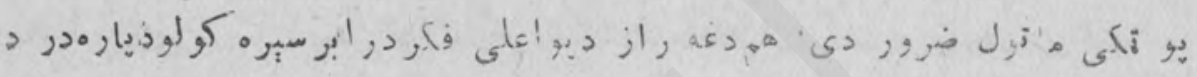

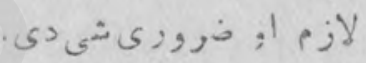
• .

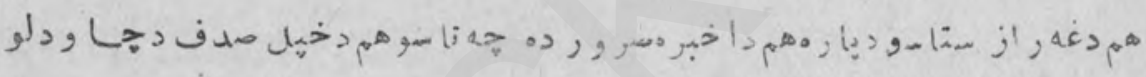

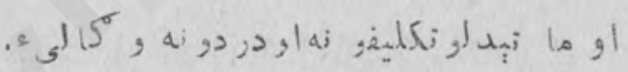

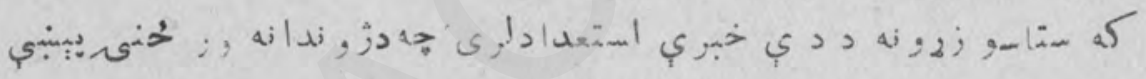

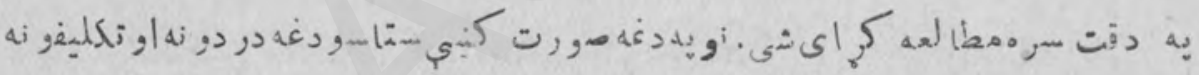

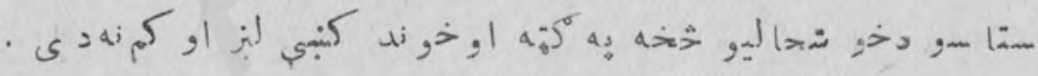

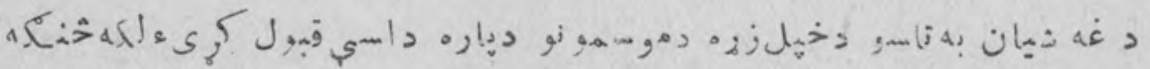

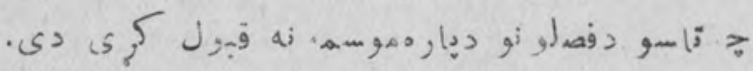
نو هز كأنه

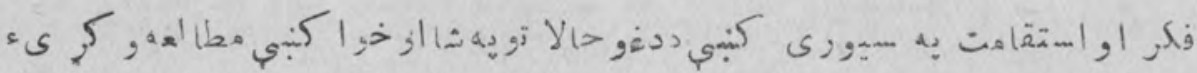

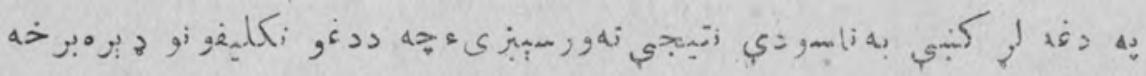

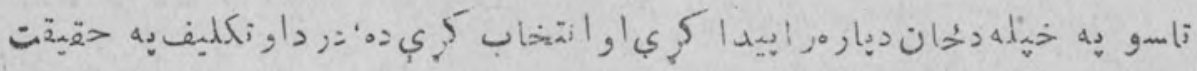

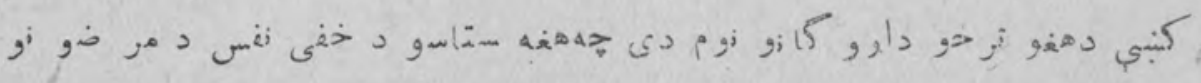

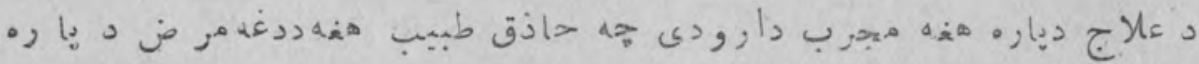
. . $1.5^{2}$ i 


\section{(or)}

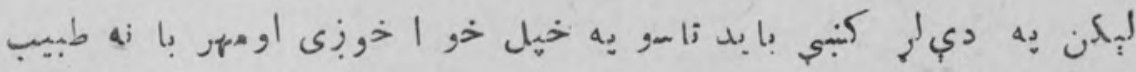

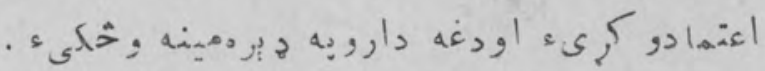

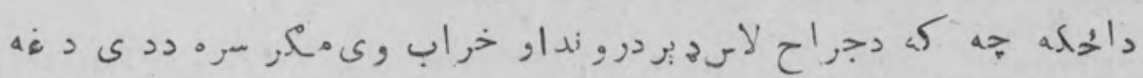

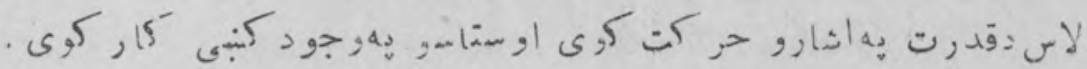

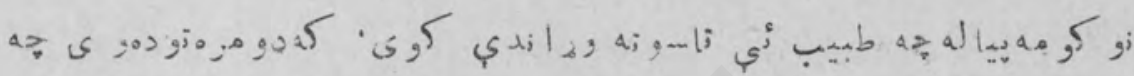

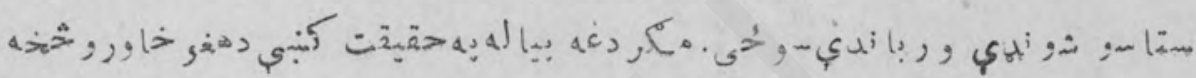

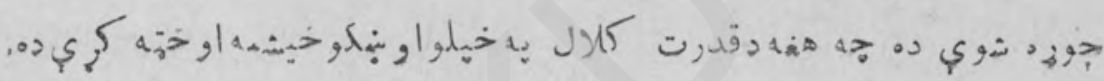
$-17$.

بيا بوهنيهيوريل:

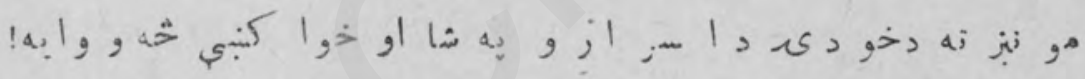
هاغه و. بل

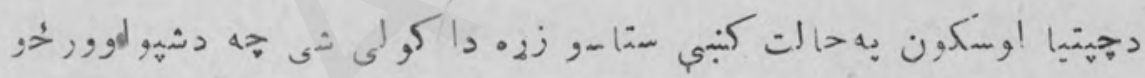

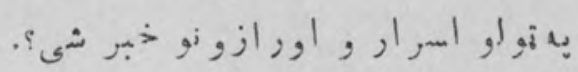

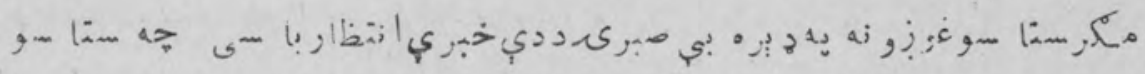
sز

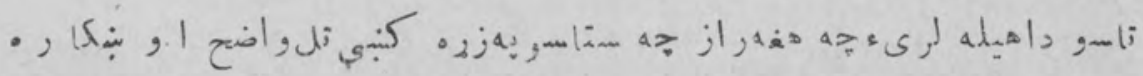

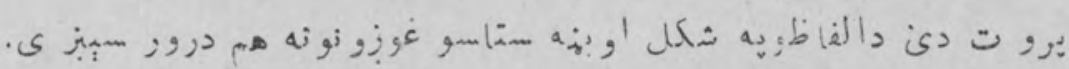

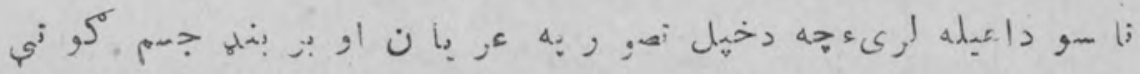

$$
\text { !. }
$$

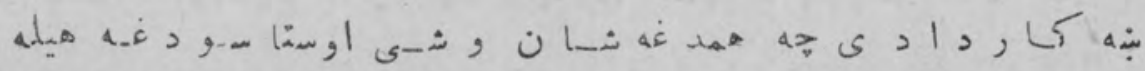

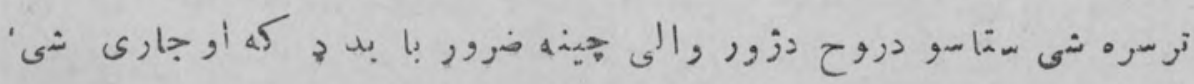




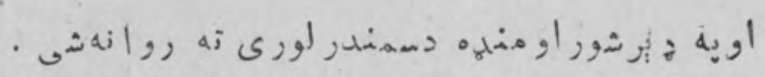

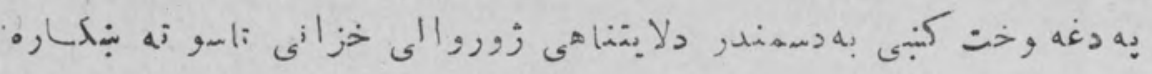

$$
\text { ا }
$$

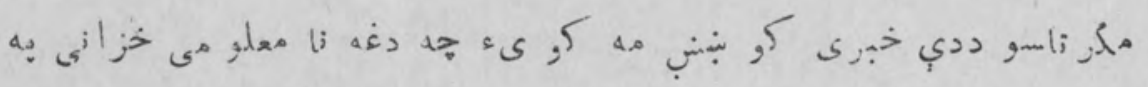

$$
\text { كو }
$$

إ i

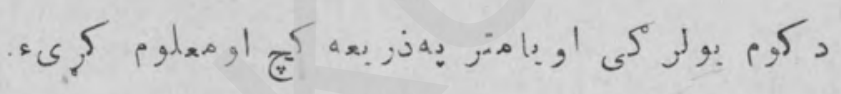

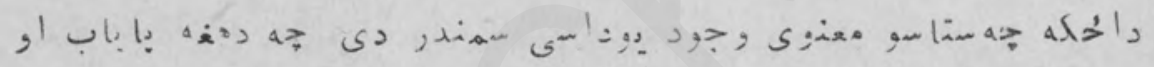

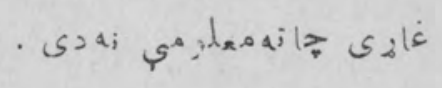

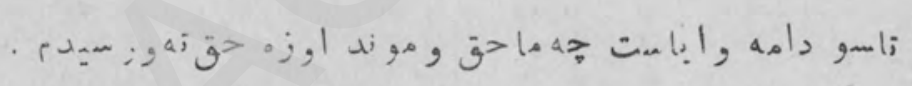

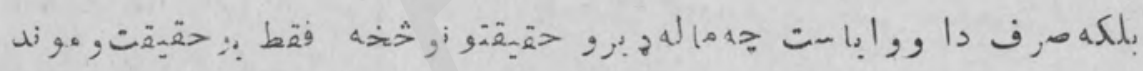

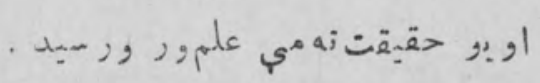

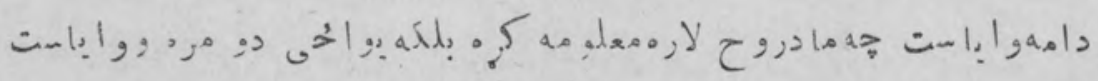

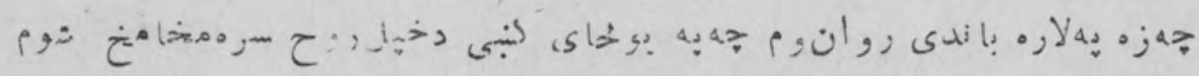

$$
\text { - . }
$$

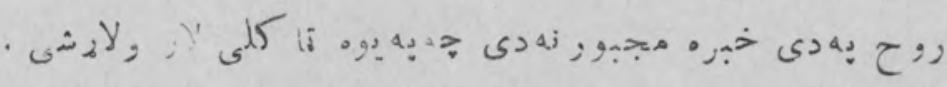

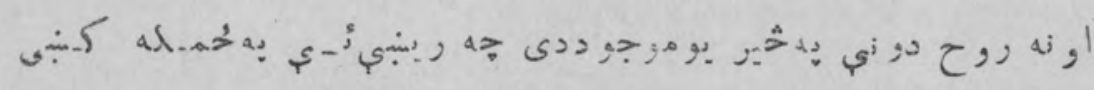

بنيخ وي .

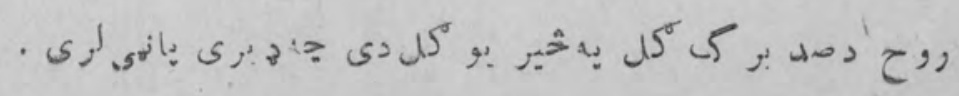


بيا يومدرس ووبل :

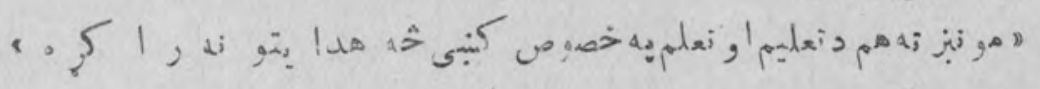
: ل

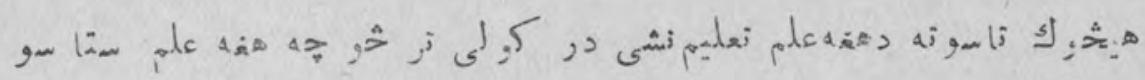

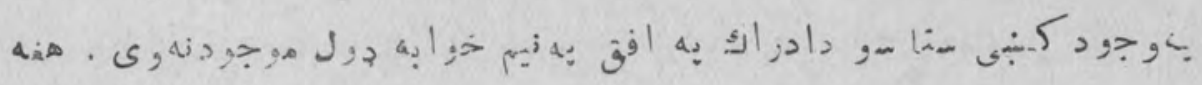

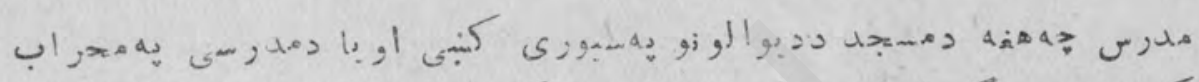

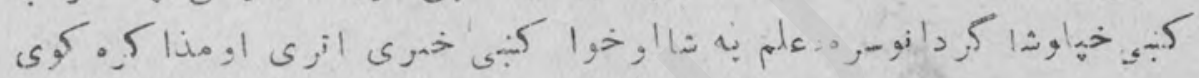

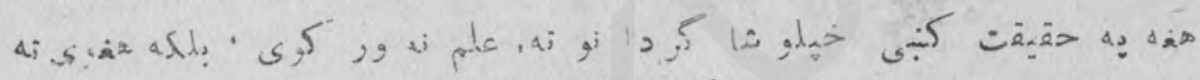

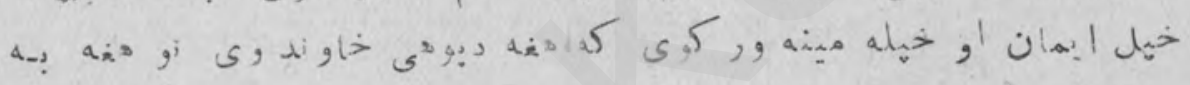

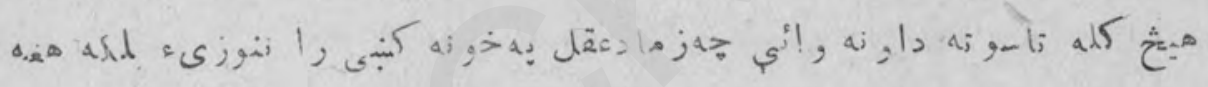

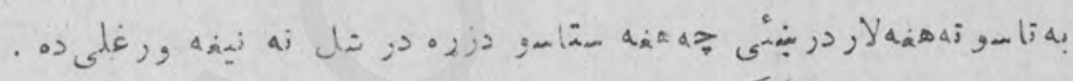

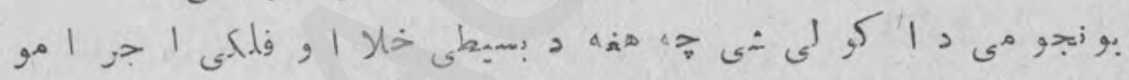

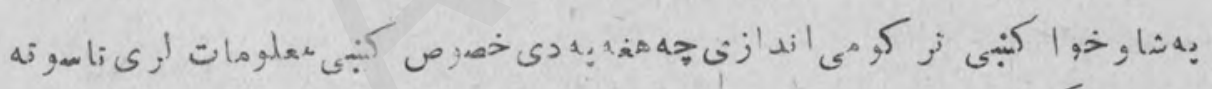

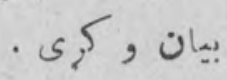

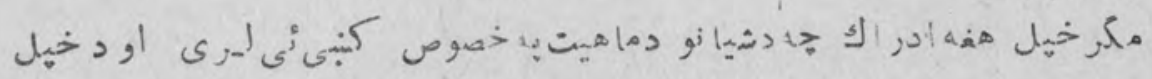

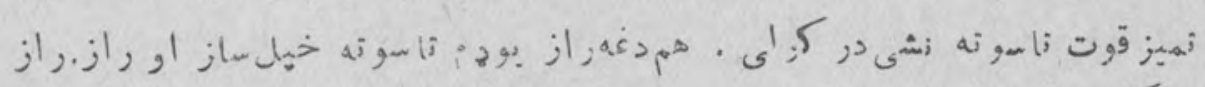
.

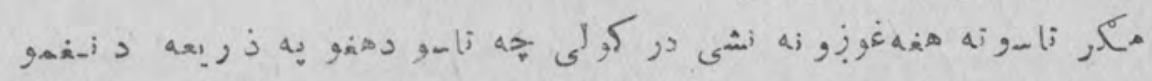

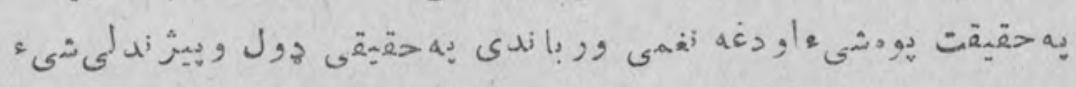

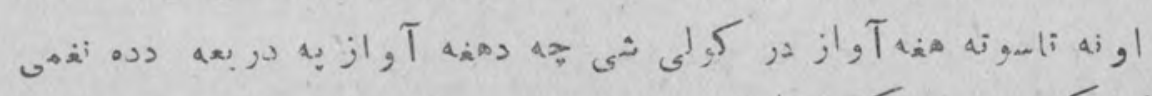

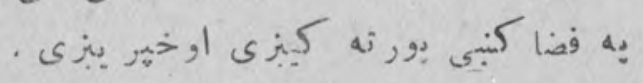

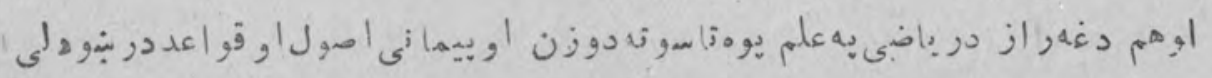

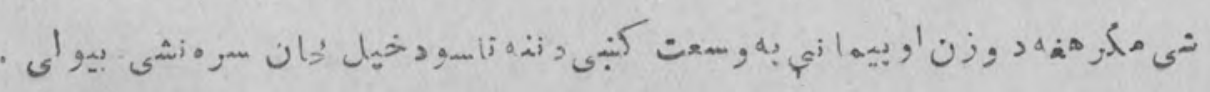




\section{(3)}

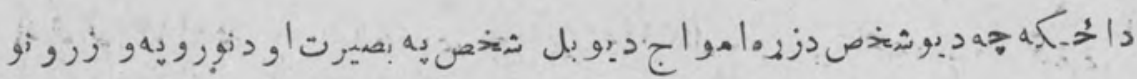

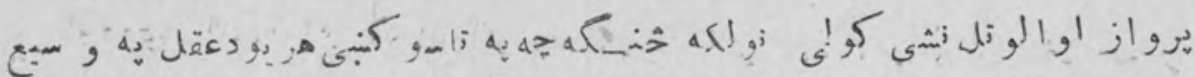

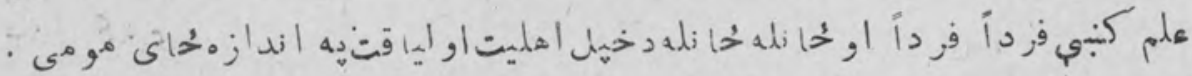

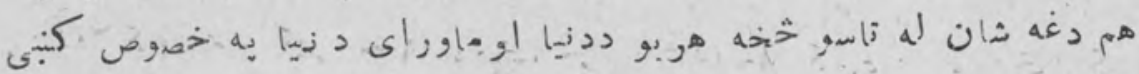
-

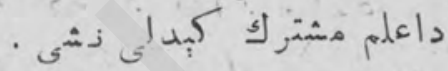

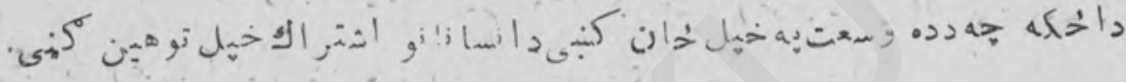
$-11$

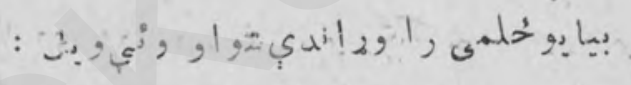

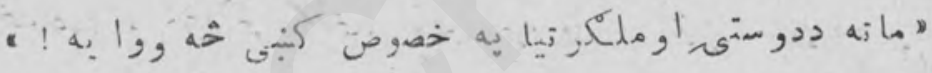

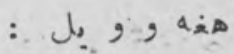

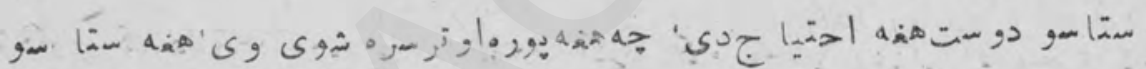

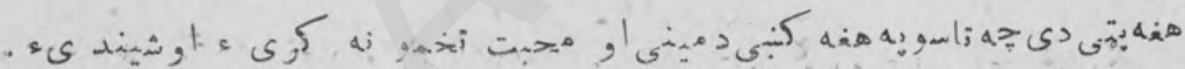

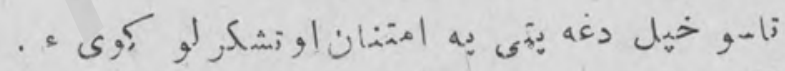

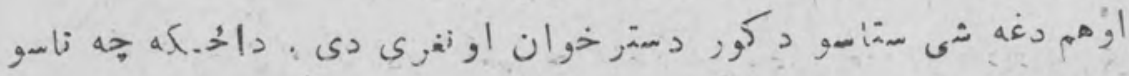

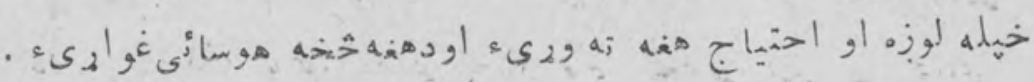

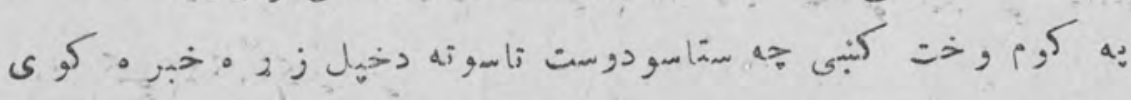

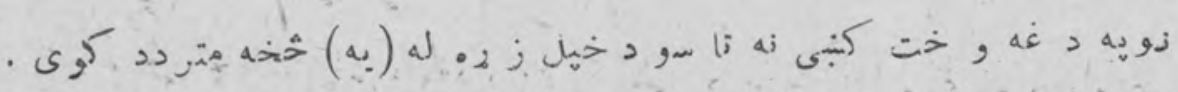

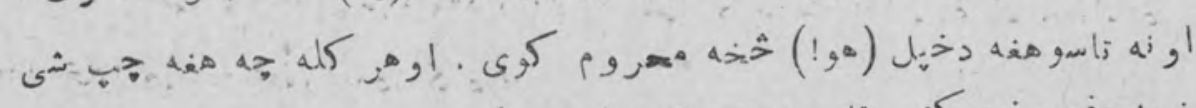

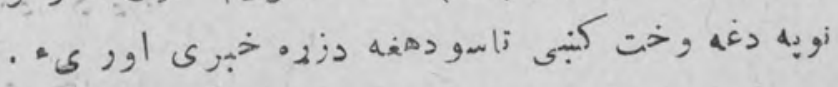

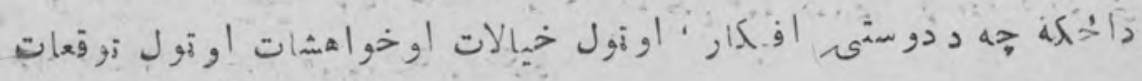




\section{(1)}

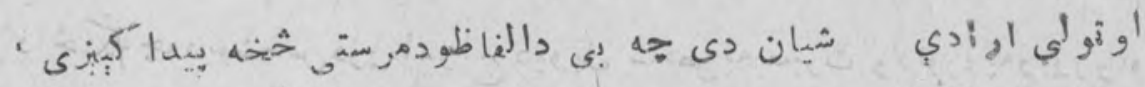

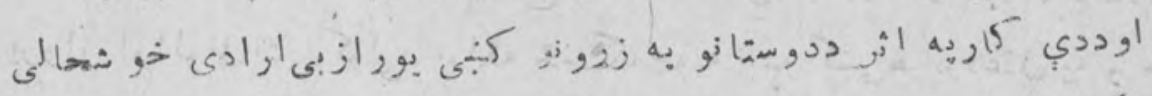

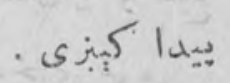

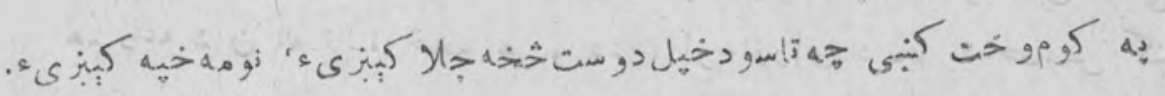

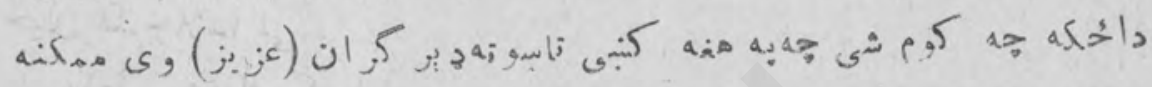

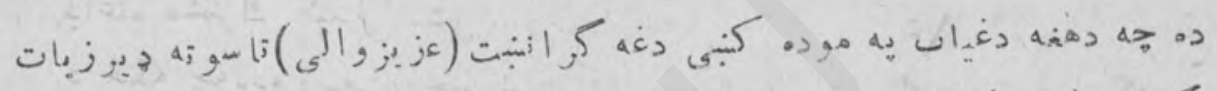

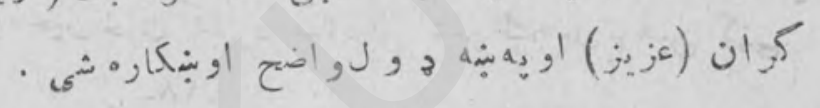

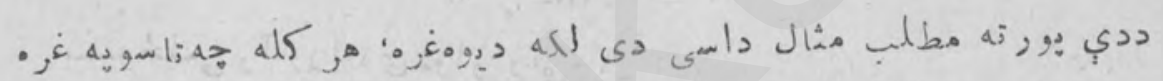

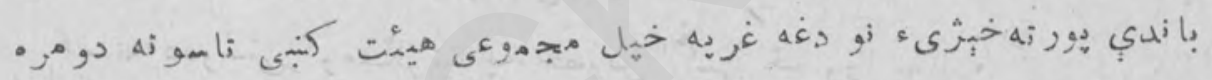

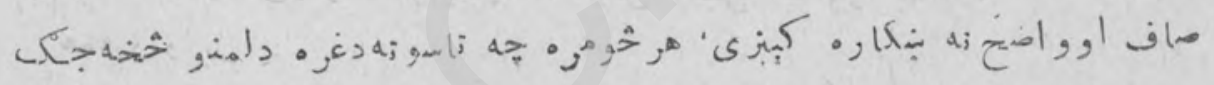

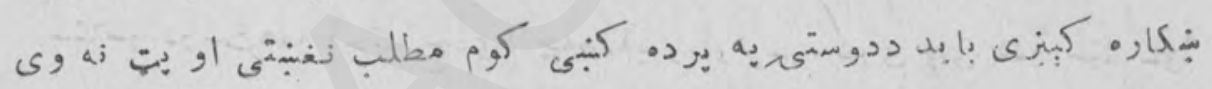

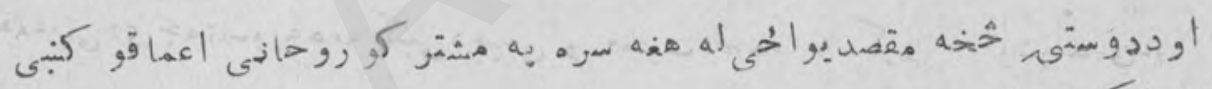

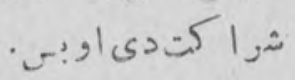

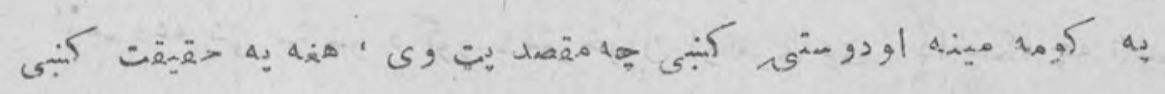

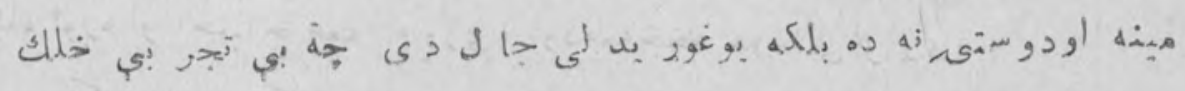

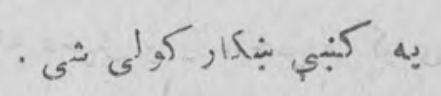

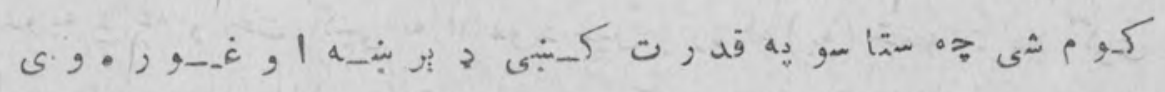

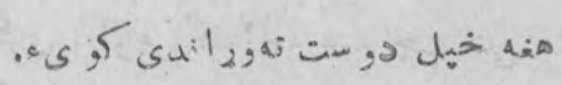

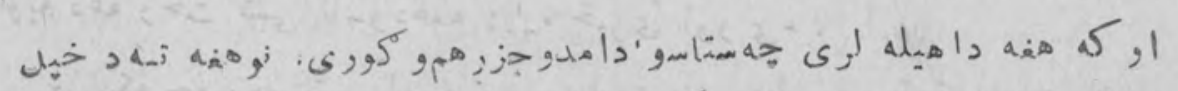

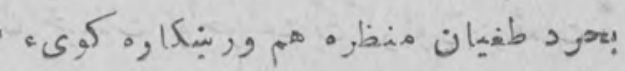




\section{$\operatorname{ton} 2$}

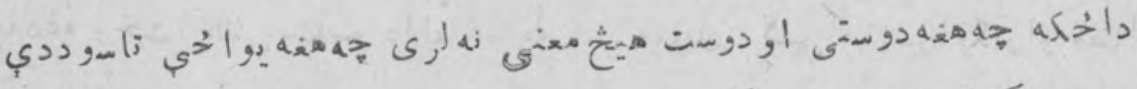

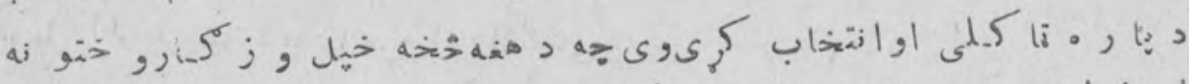

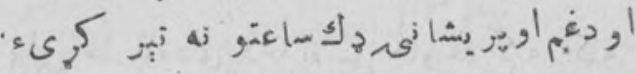

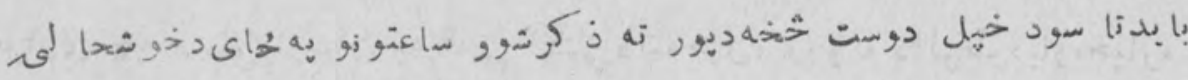

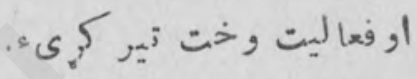

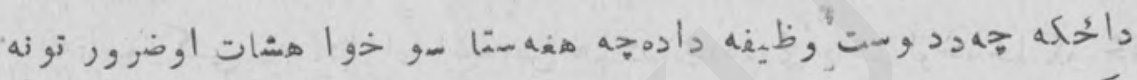
:

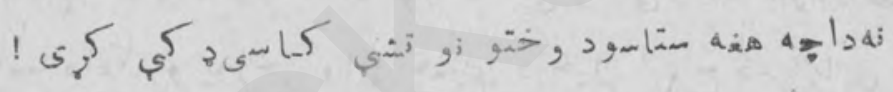

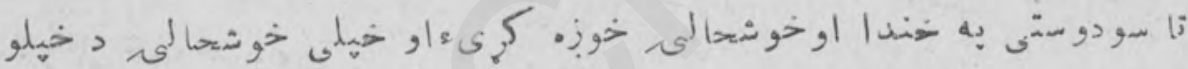

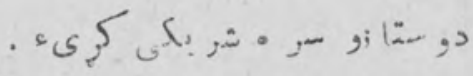

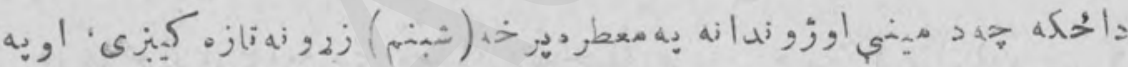

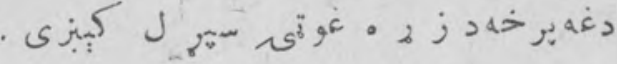

$$
\begin{aligned}
& -18 .
\end{aligned}
$$

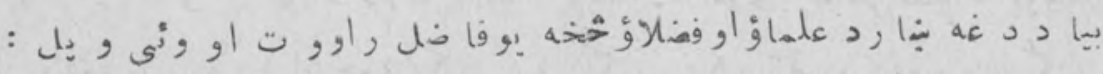

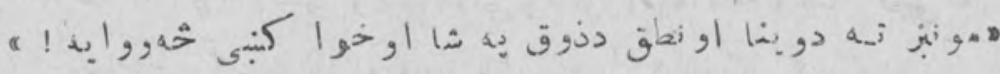
: M ب

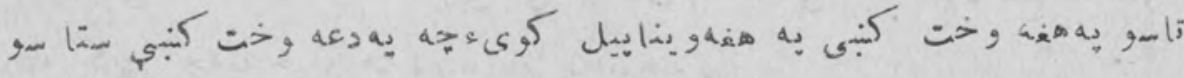

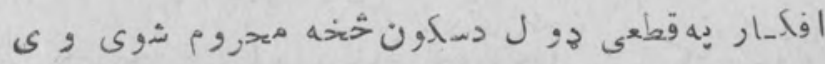

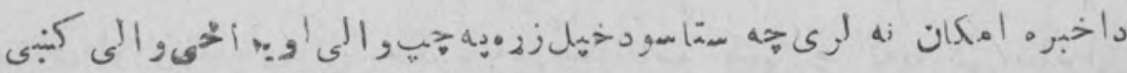

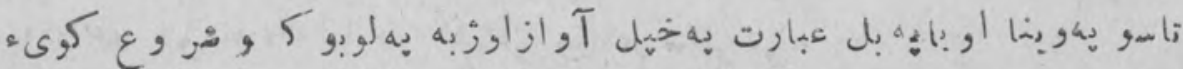




\section{(u)}

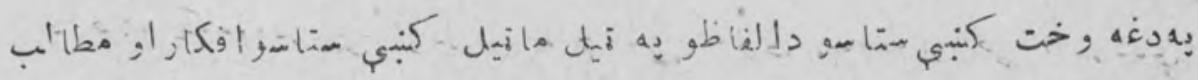

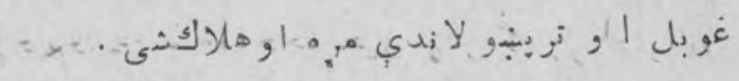

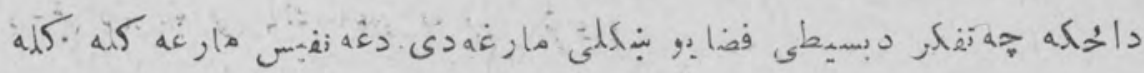

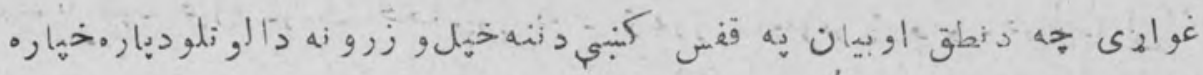

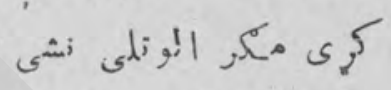

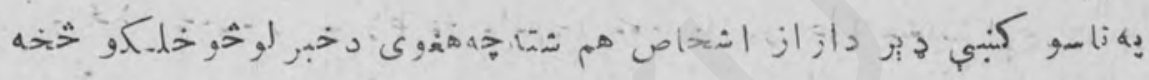

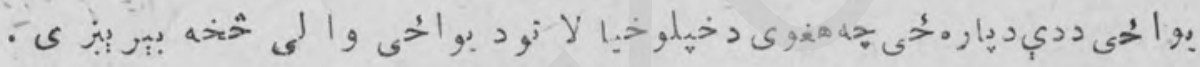
ا

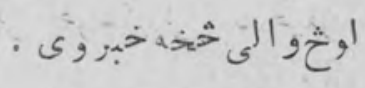

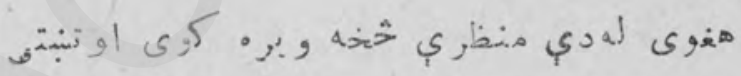

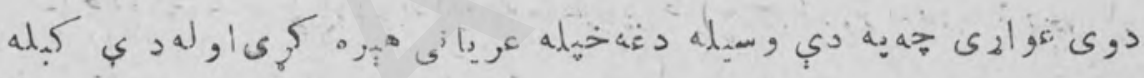

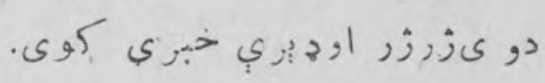

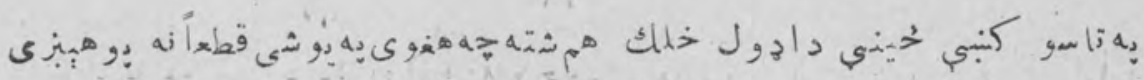

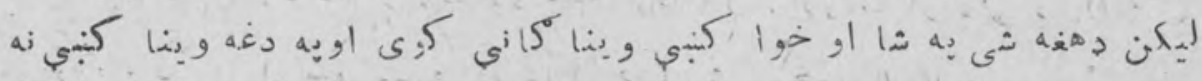

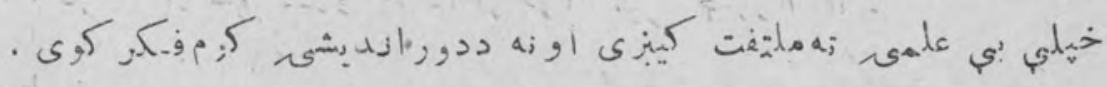

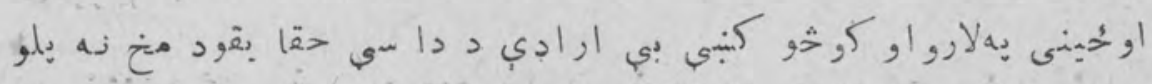

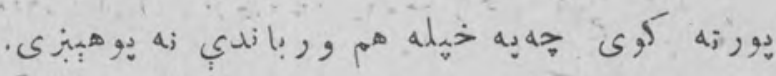

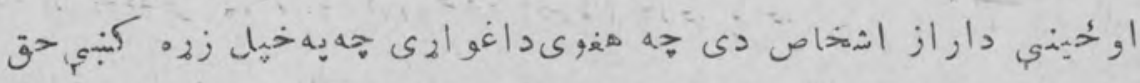

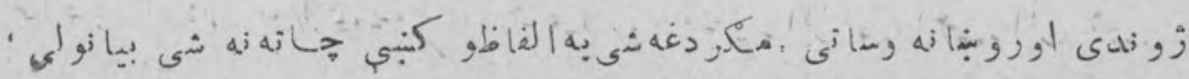

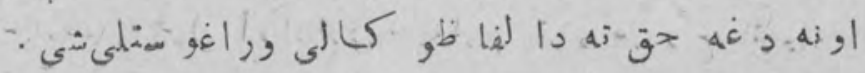




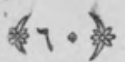

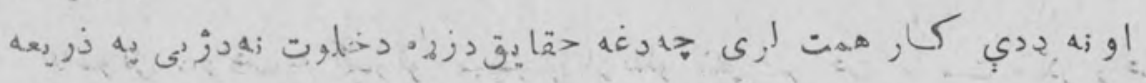
دبازندي راوباسي.

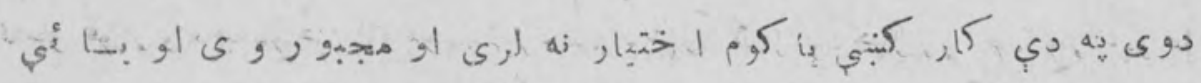

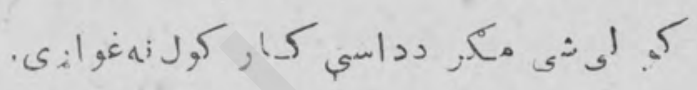

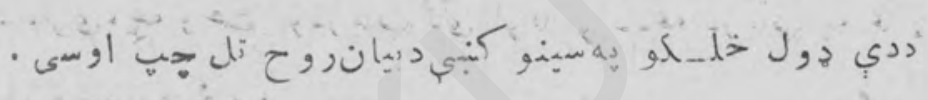
.

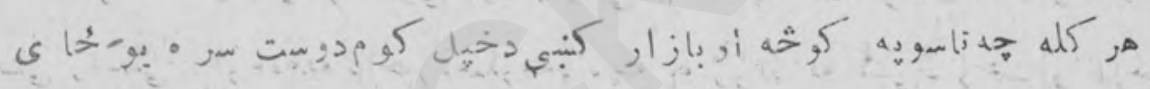

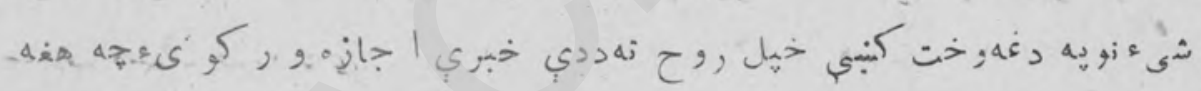

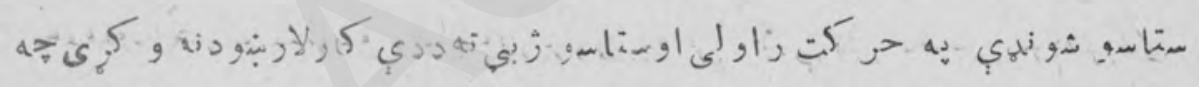

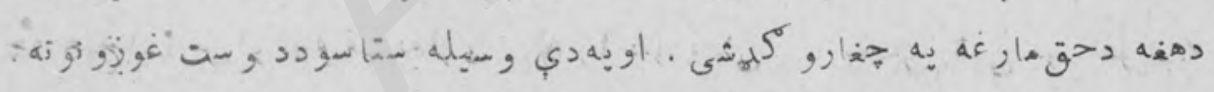

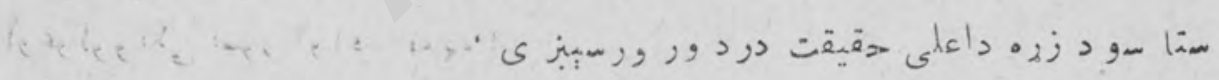

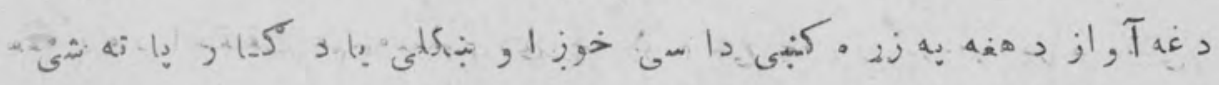

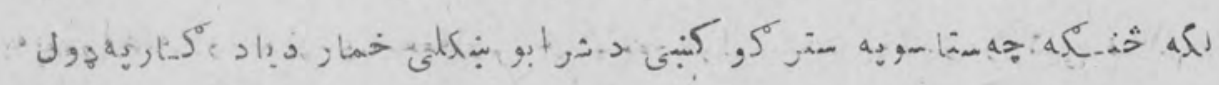

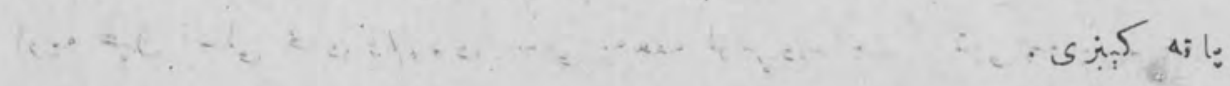

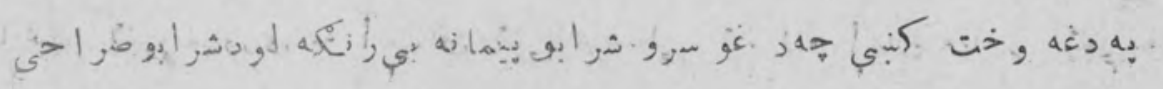

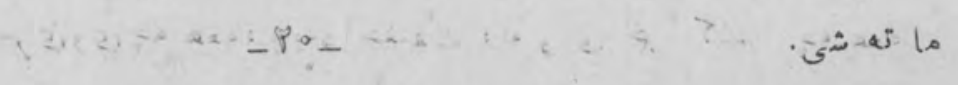

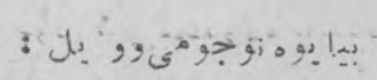

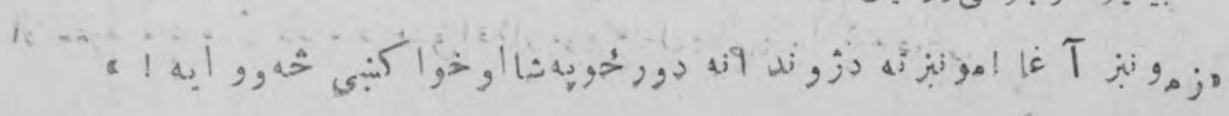




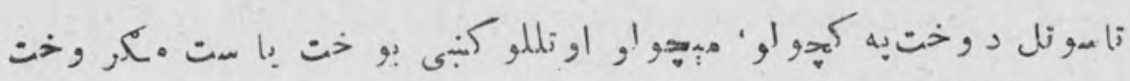

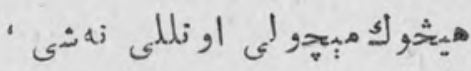

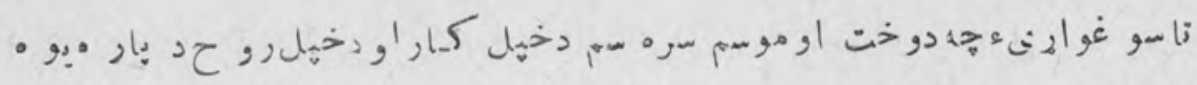

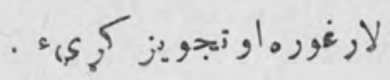

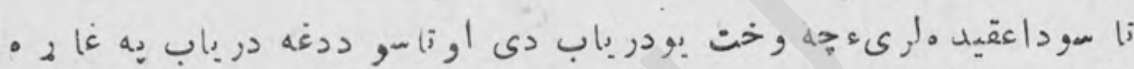

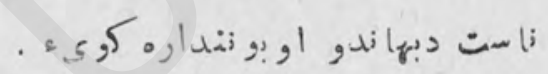

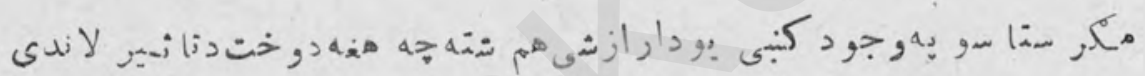

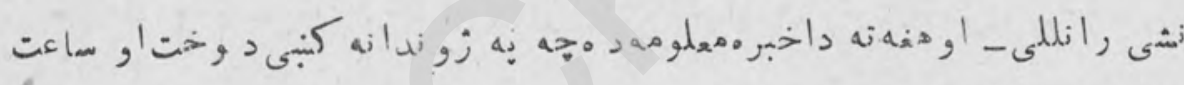

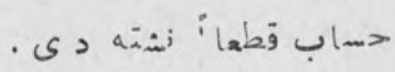

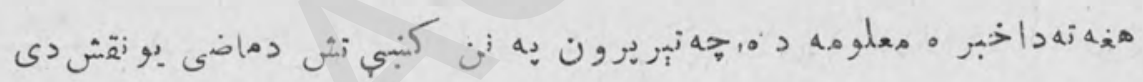

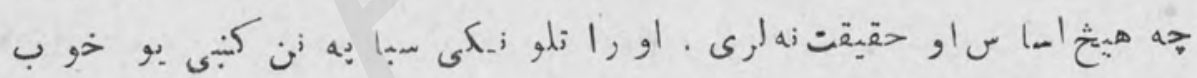

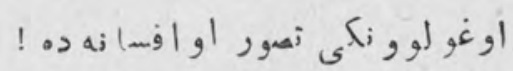

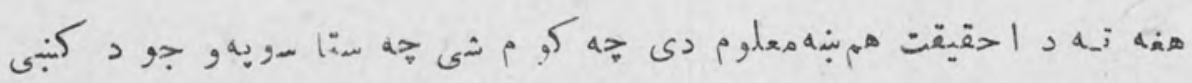

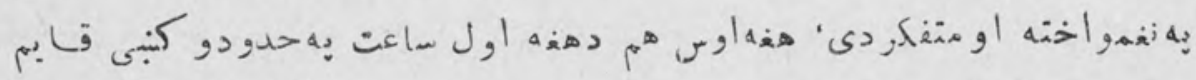

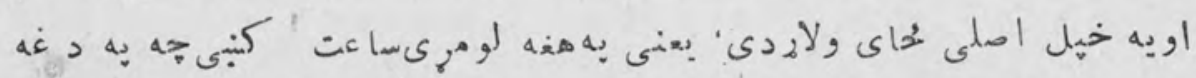

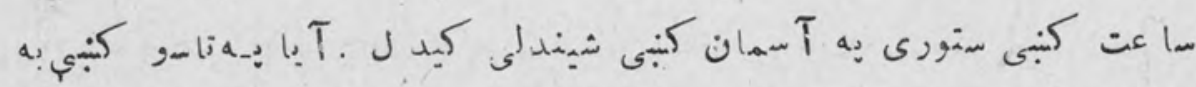

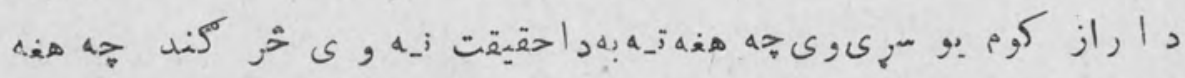

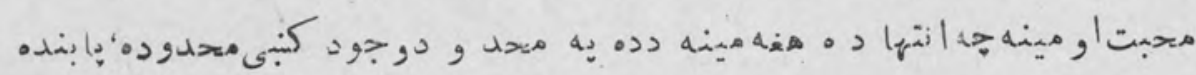

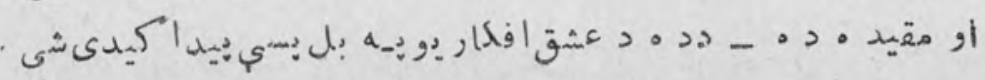




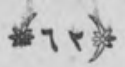

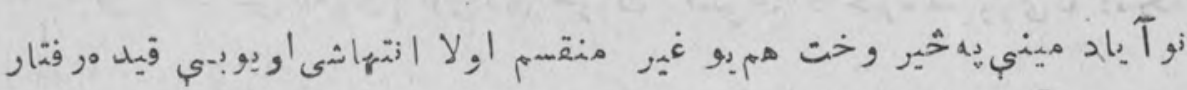

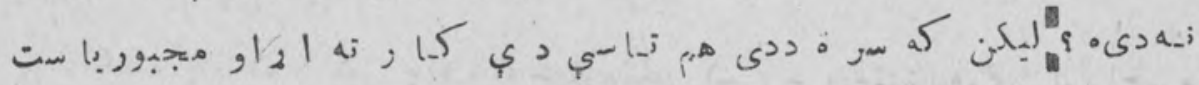

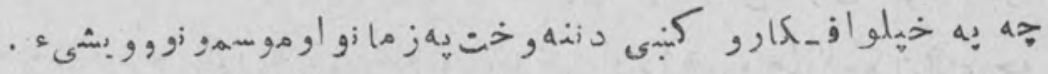

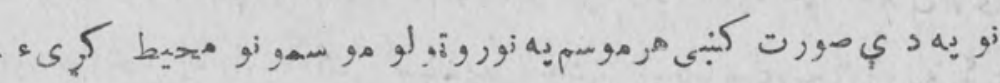

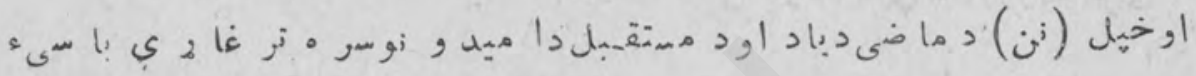

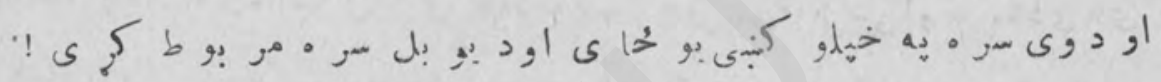
- PI_

بيا دكلى مشر انو اوخانانو وروبل:

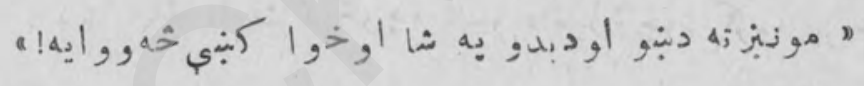

هانهوبو :

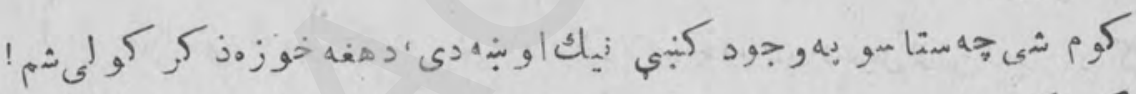

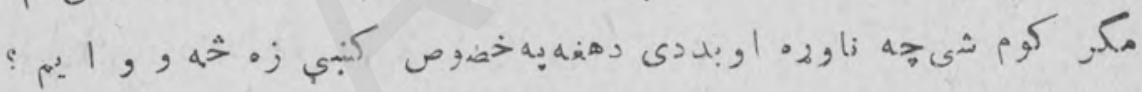
هن

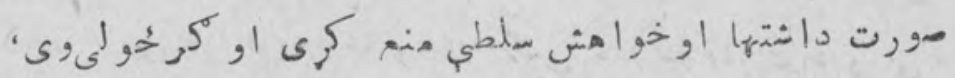

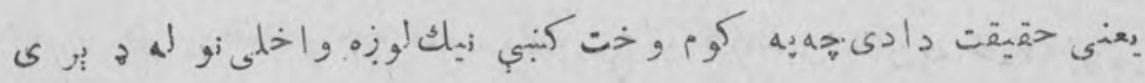

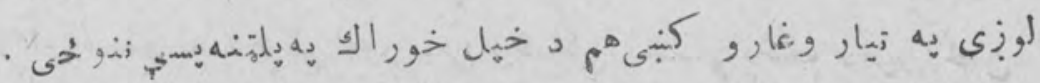

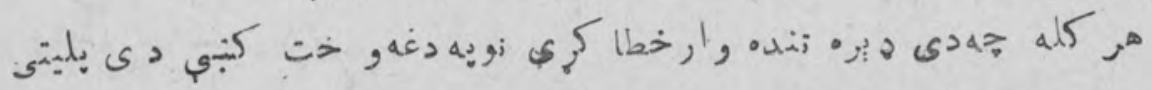

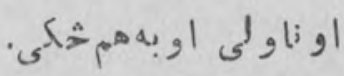

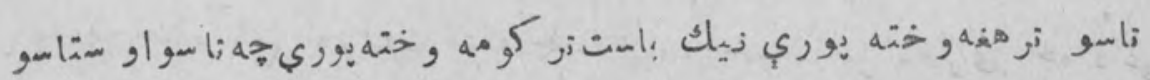

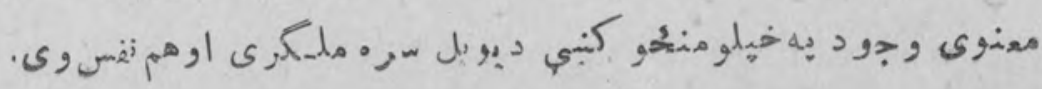




\section{(4r)}

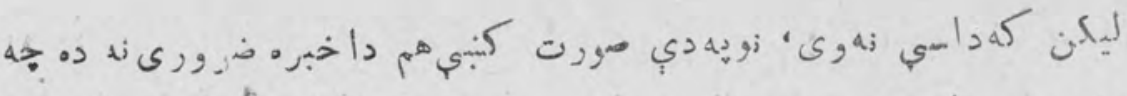
i

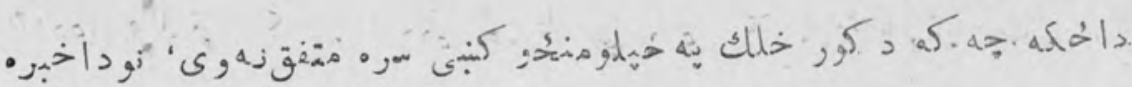
هن

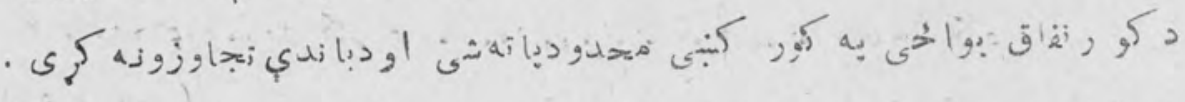

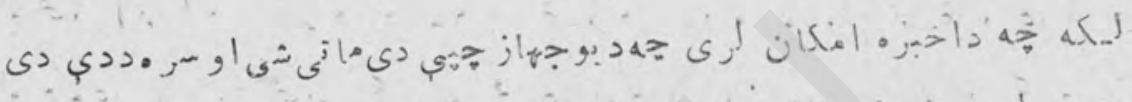

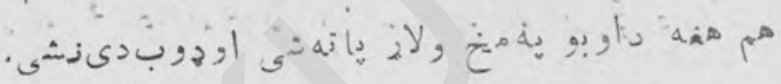

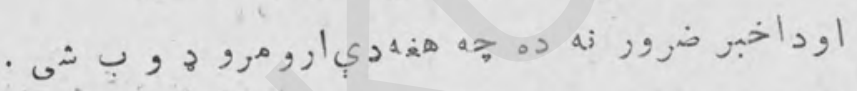

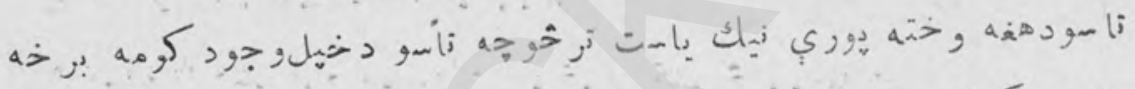
نورو ته ور كولاى شیى

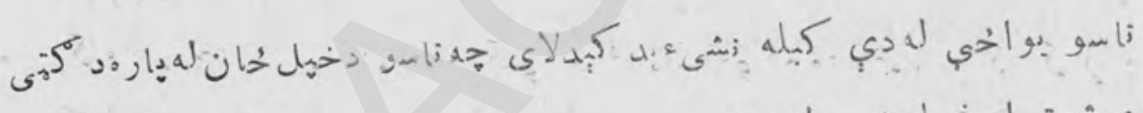

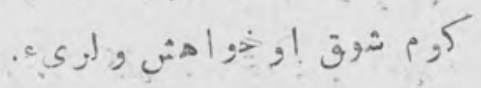
دار

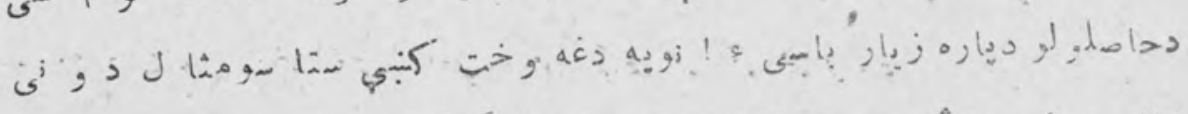

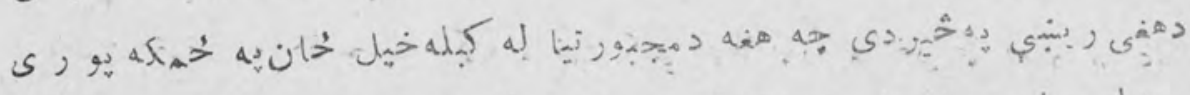

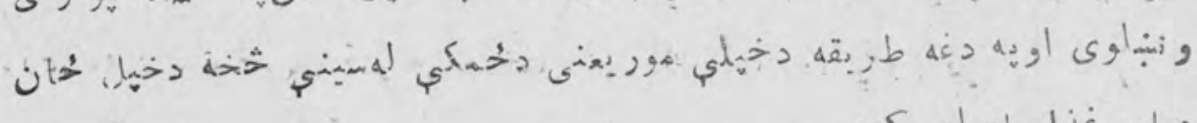
. 5 . كم

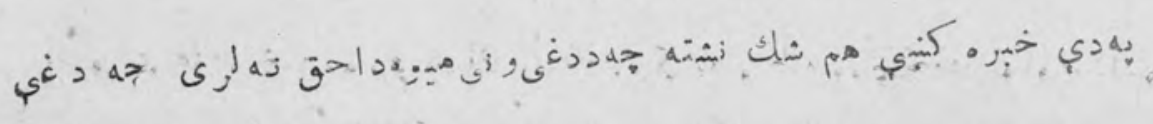




\section{1 (}

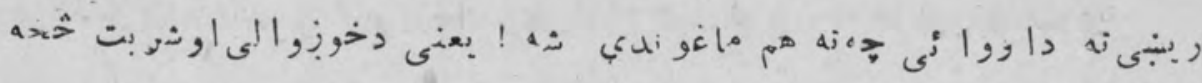
14

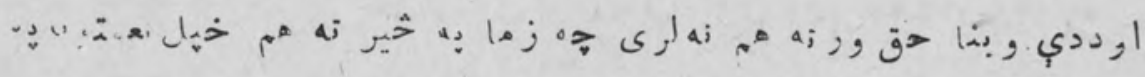

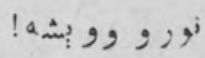

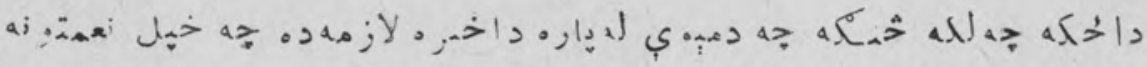

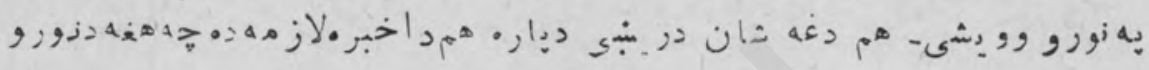

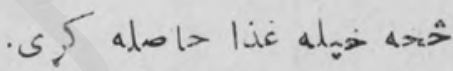

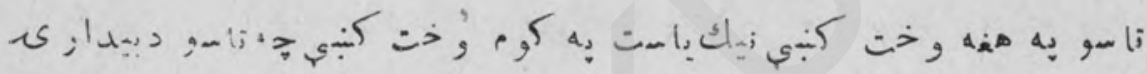

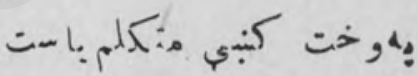

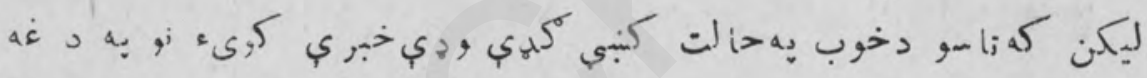

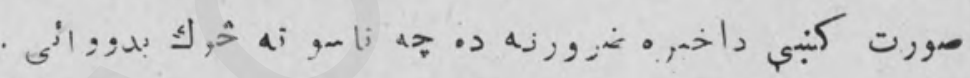

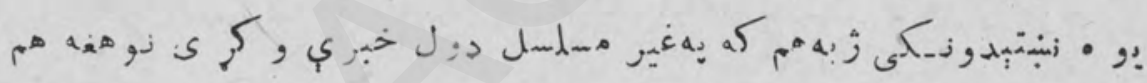
-

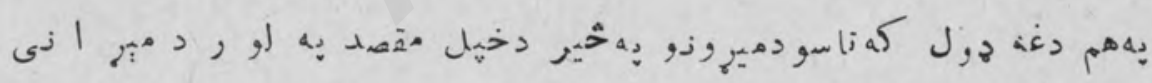

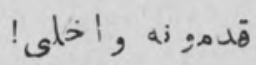

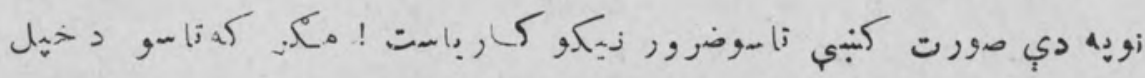

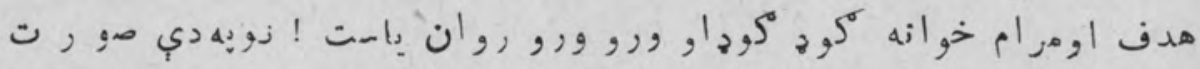

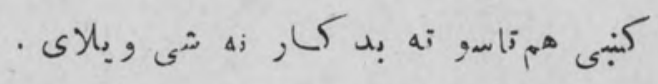

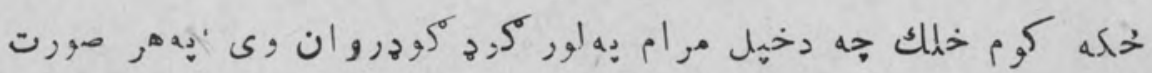
ن 


\section{(10)}

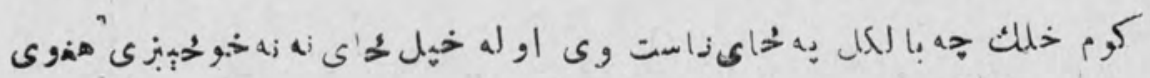

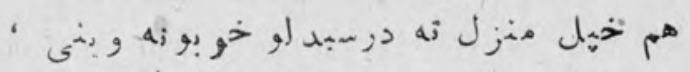

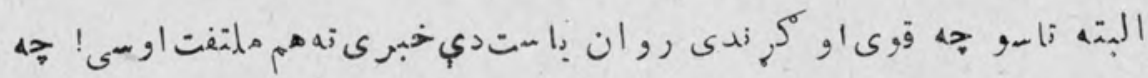

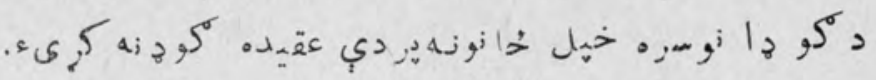

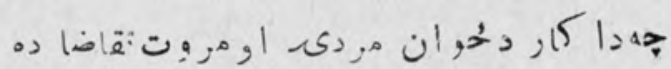

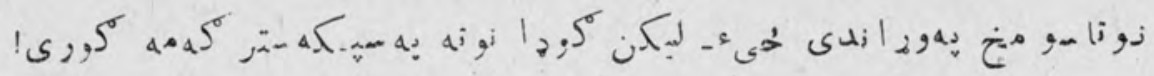
.

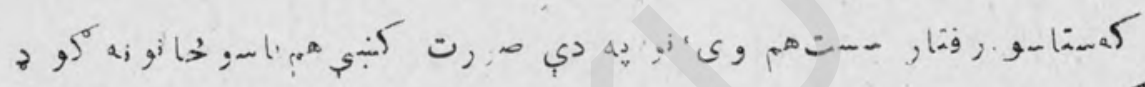

. $=4 i^{\circ}$ as

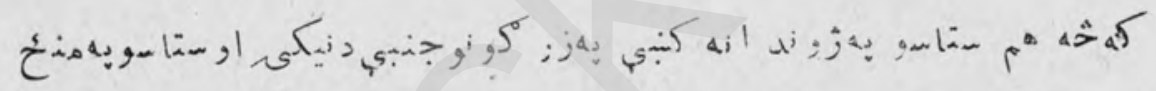

$$
\text { كنبي > إلى }
$$

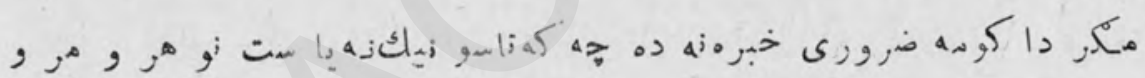

بدبدايت

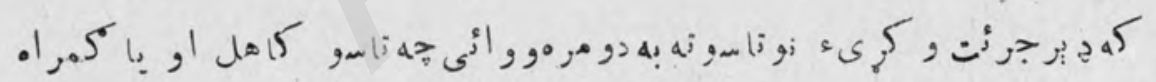

!

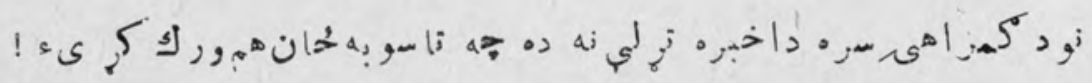

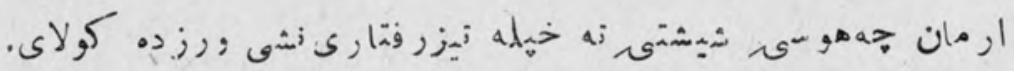

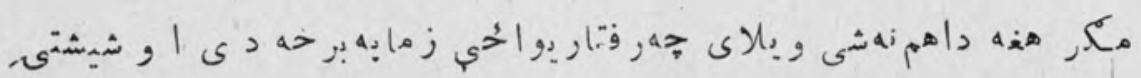

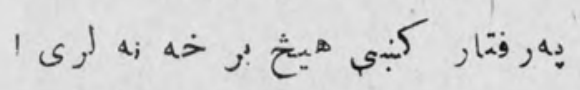

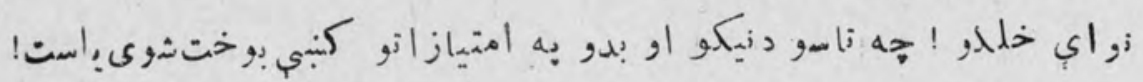




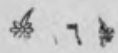

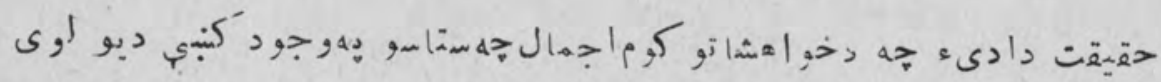

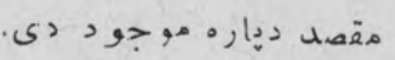

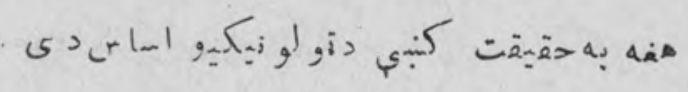

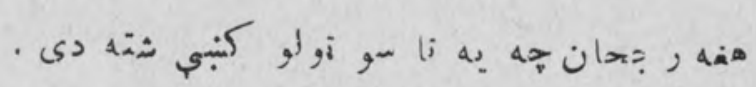

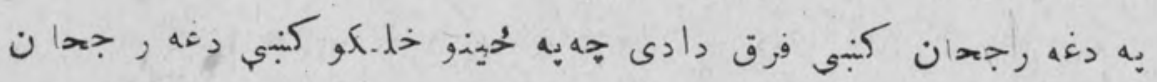

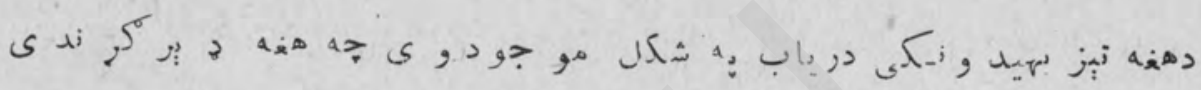

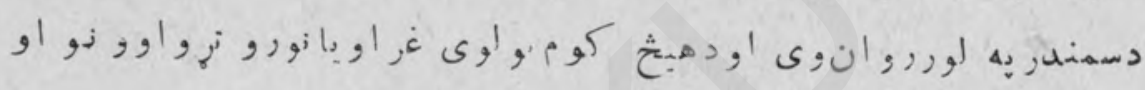

$$
\text { . }
$$

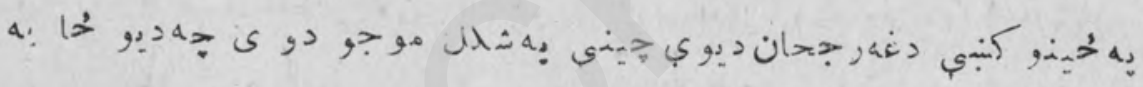

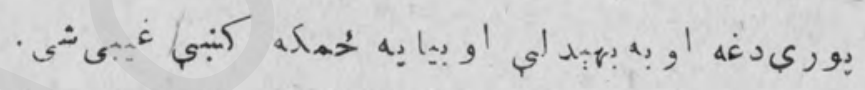

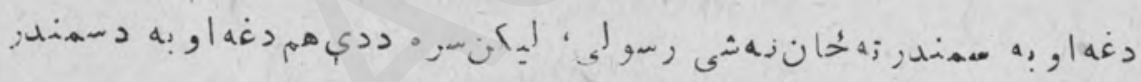

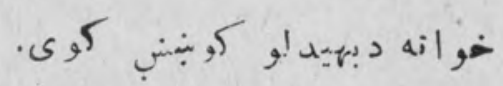

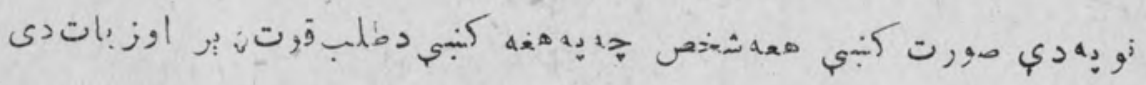

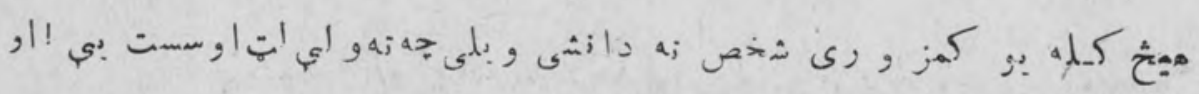

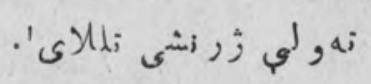

و إنها

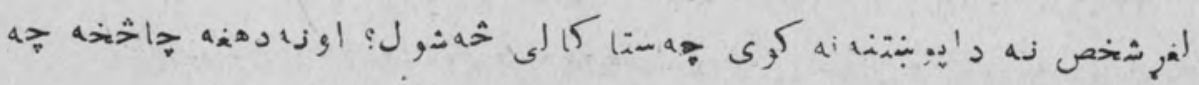

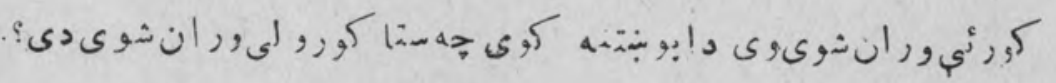


(iv)

\section{- $3 i-$}

بيا بوه مر شدوروبل:

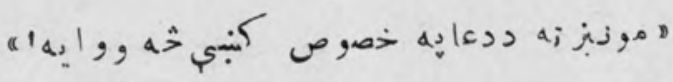

هi:وبل:

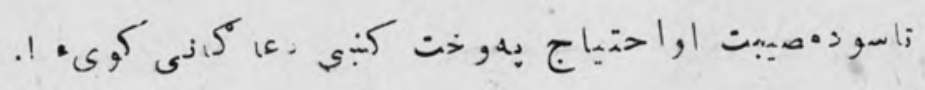

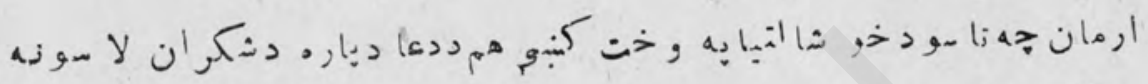

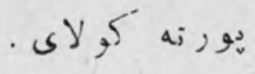

:

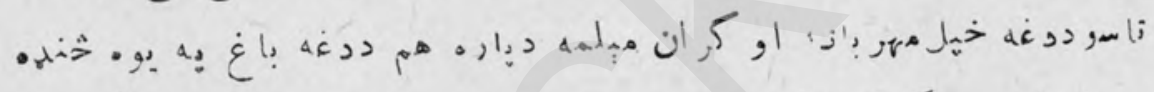

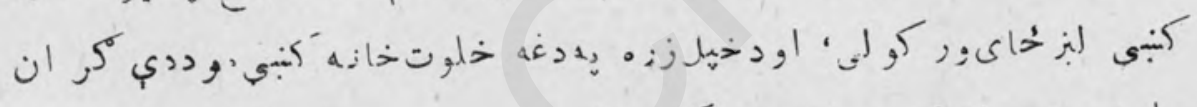
.

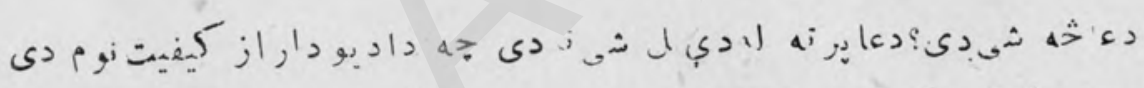

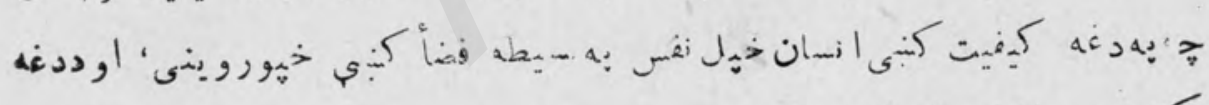
. S,

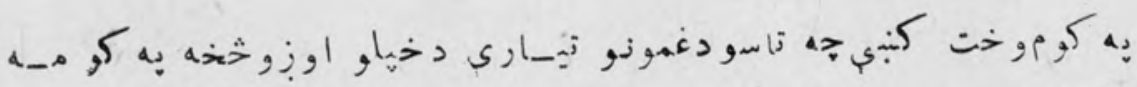

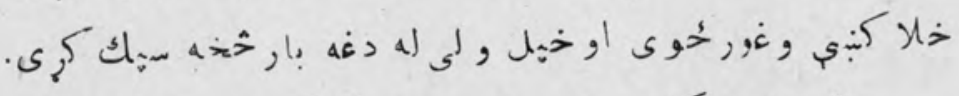

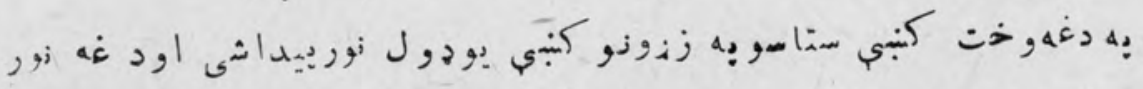

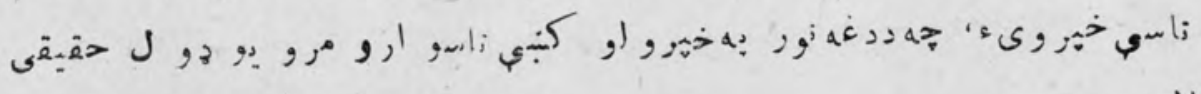

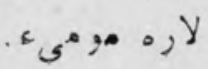




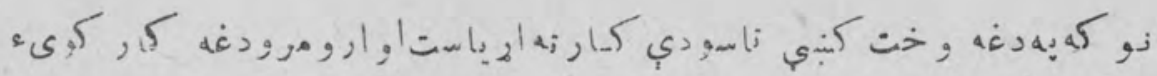

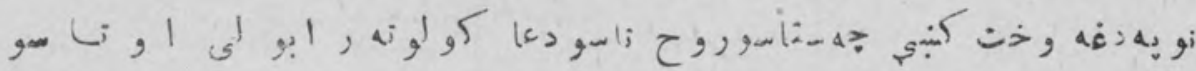

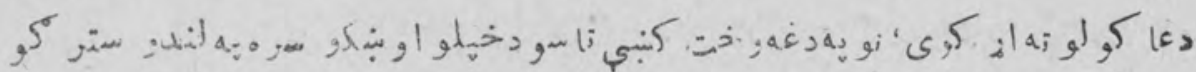

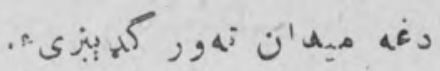

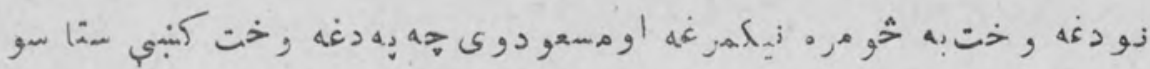

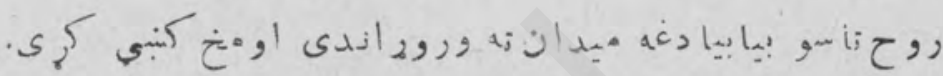

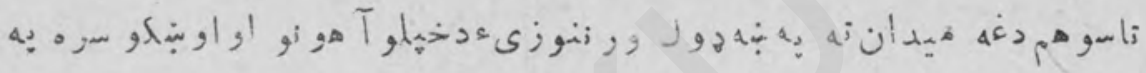

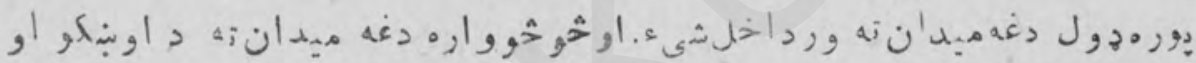

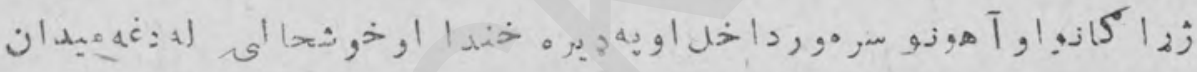
Is $s ;, 1$, a $; \ldots$ a)

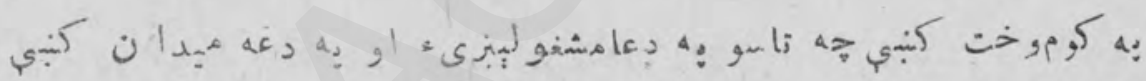

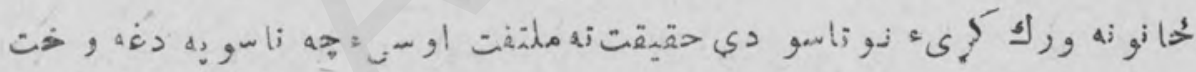

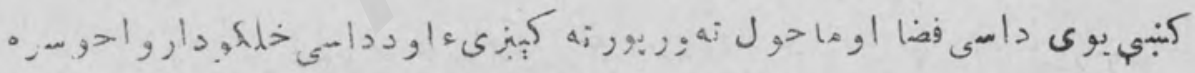

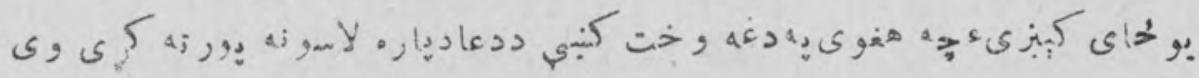

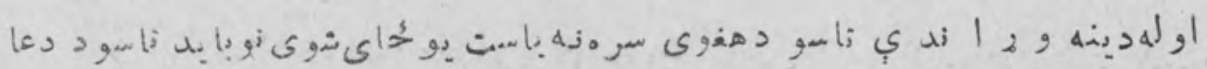

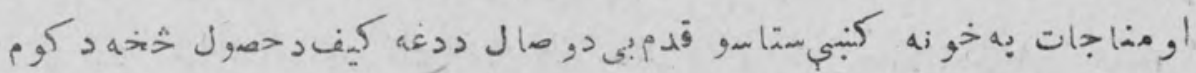

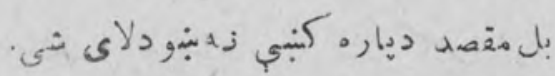

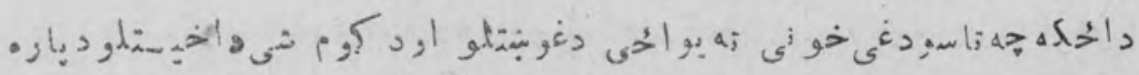

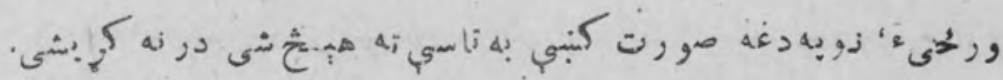




\section{$\$ 2$}

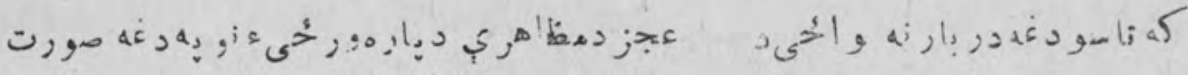

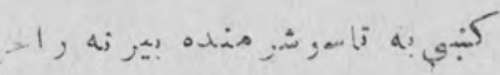

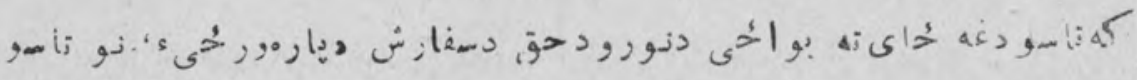
放

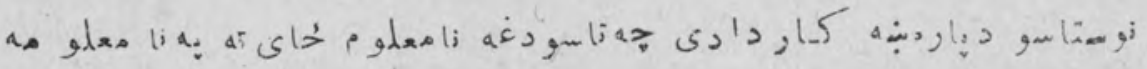

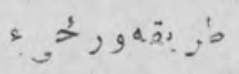

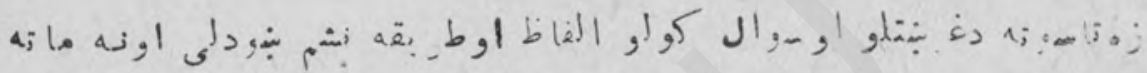

$$
\text { - د }
$$

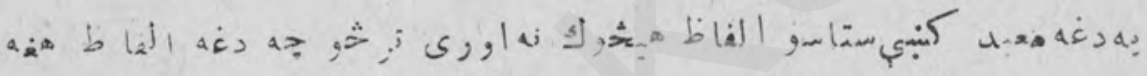

الفاظ

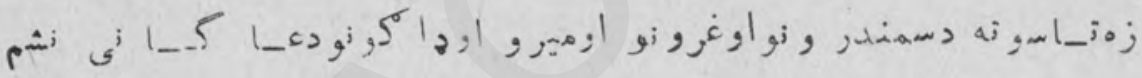

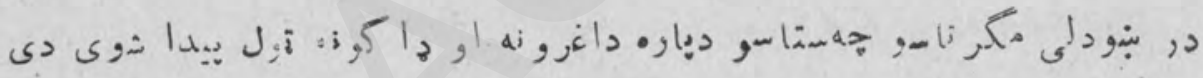

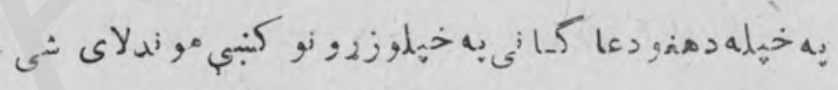

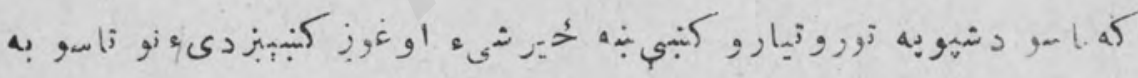

$$
\text { دسمندر د }
$$

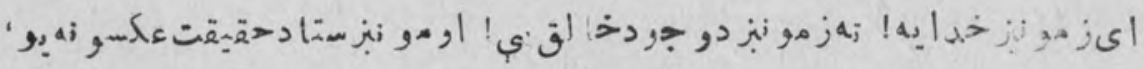

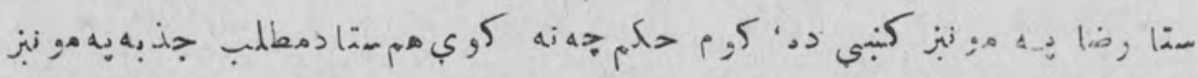

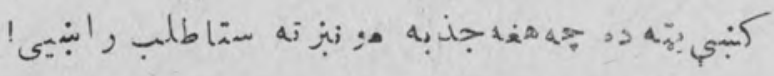

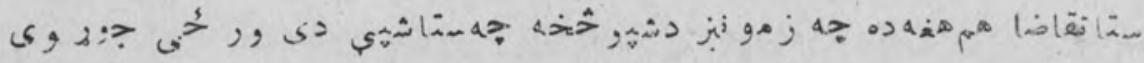

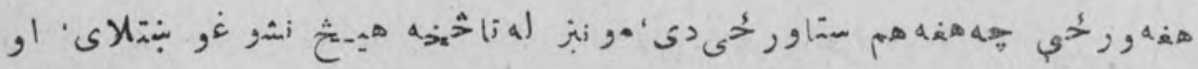




\section{(2)}

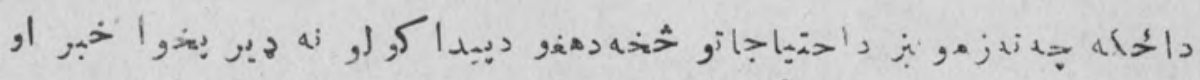

$$
\begin{aligned}
& \text { اقف:بي }
\end{aligned}
$$

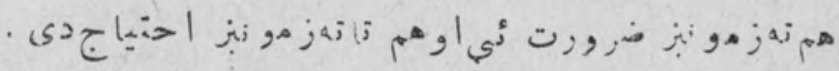

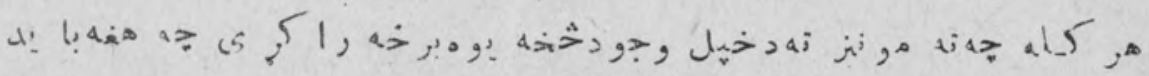

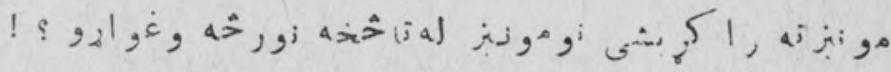

$$
\begin{aligned}
& -P P^{2}-
\end{aligned}
$$

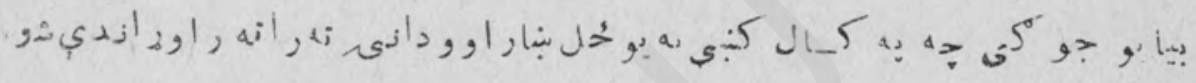

$$
\text { : } 1
$$$$
\text { مو أبز a }
$$

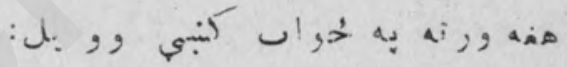

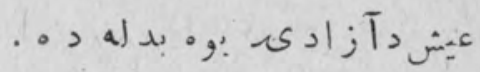

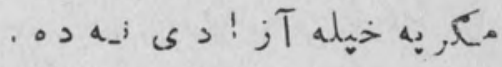

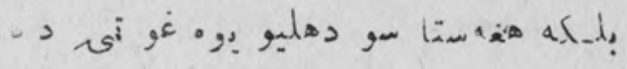

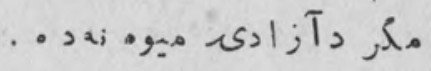

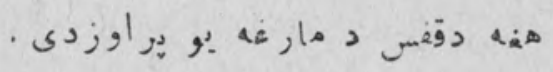

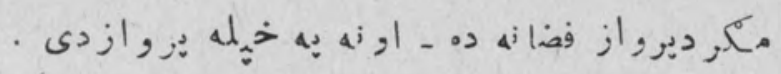

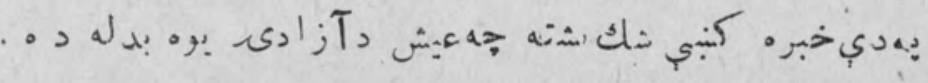

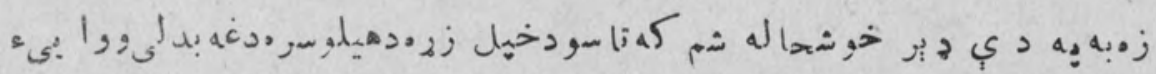

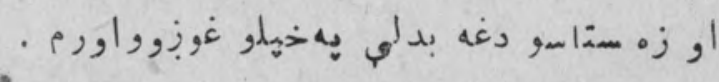




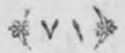

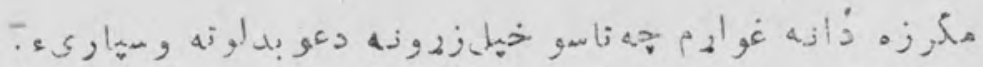

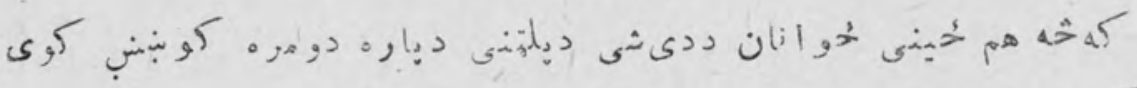

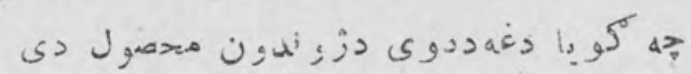

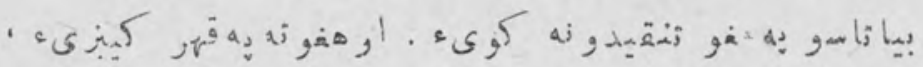

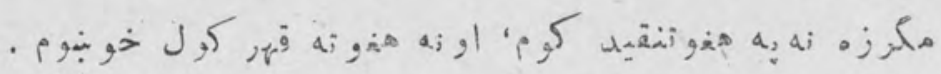

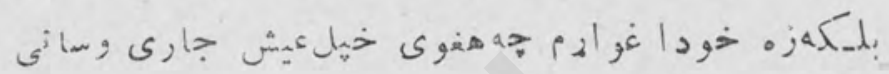

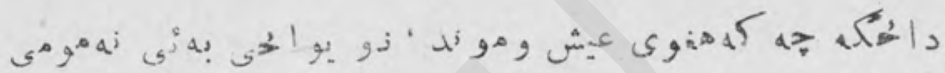

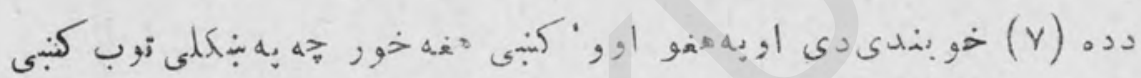

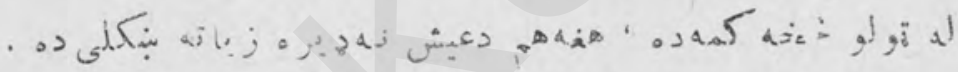

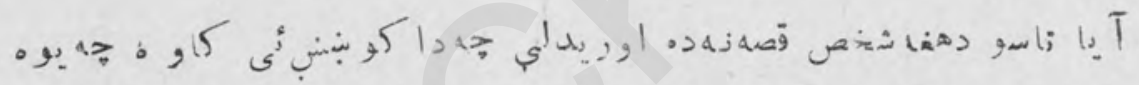

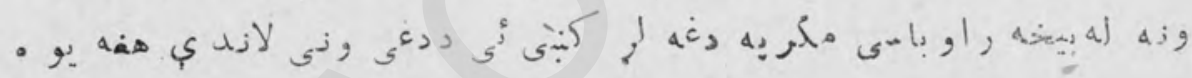

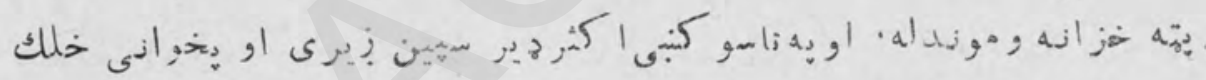

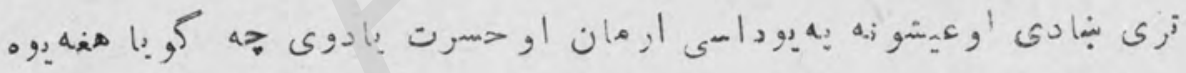

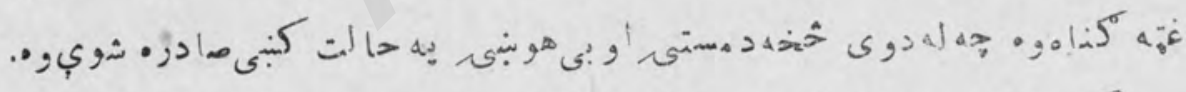

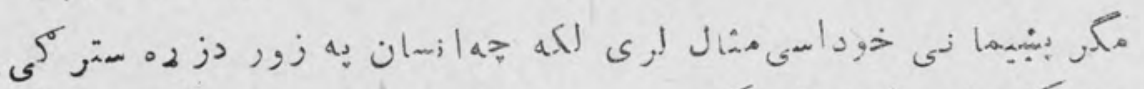

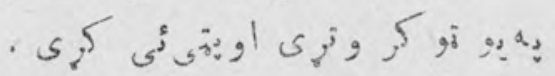

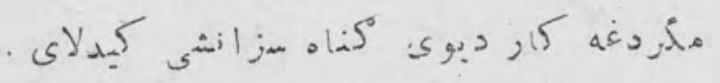

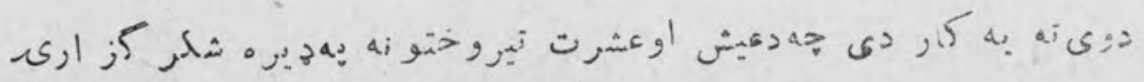

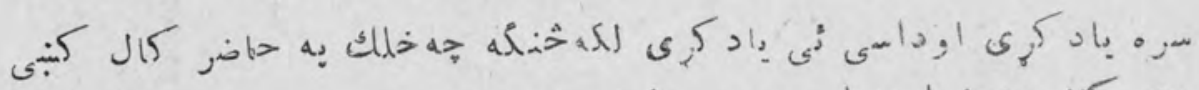

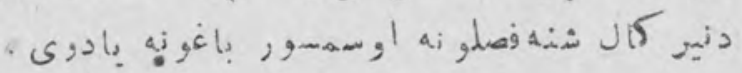




\section{(ve)}

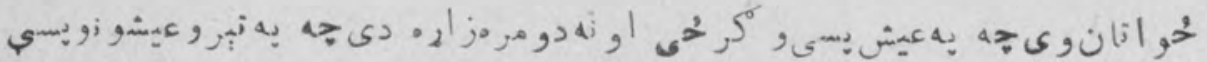

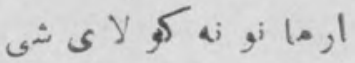

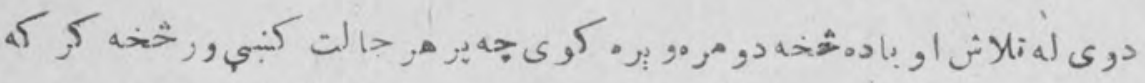

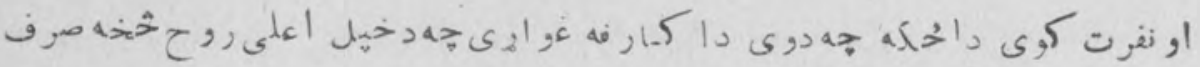

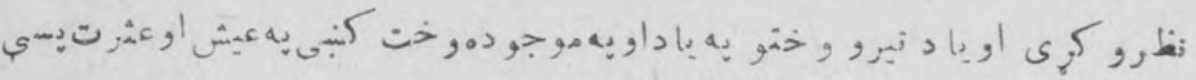

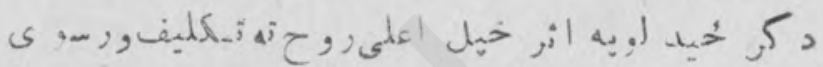

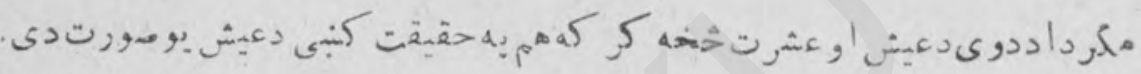

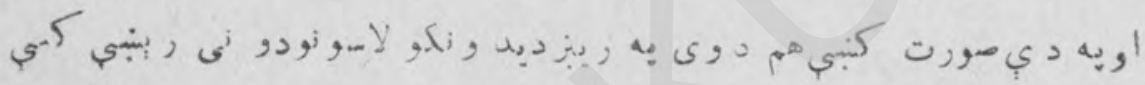

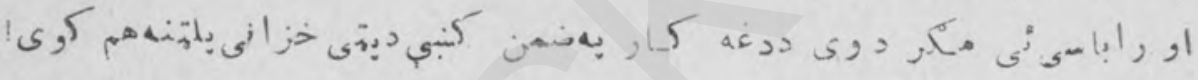

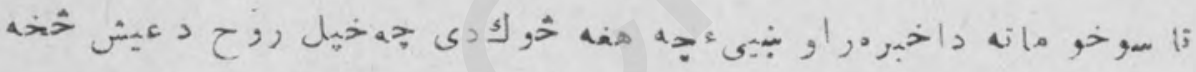

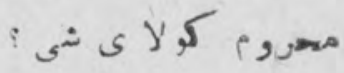

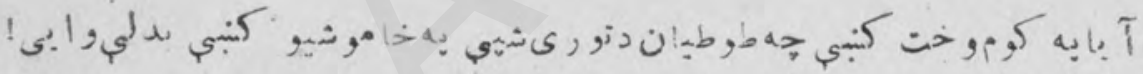

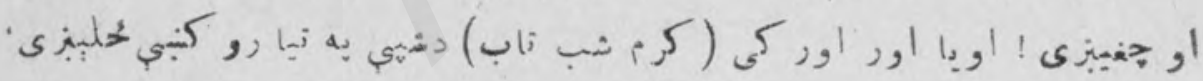

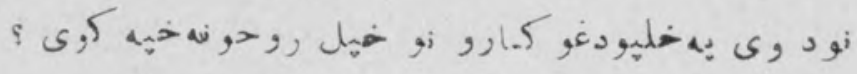

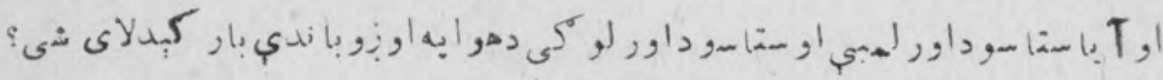

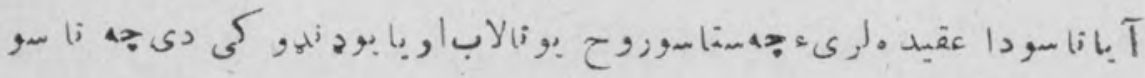

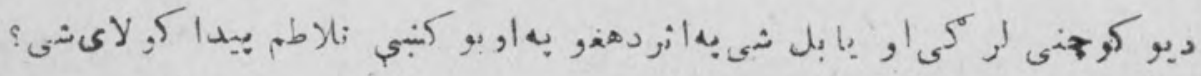

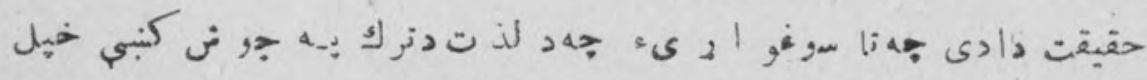

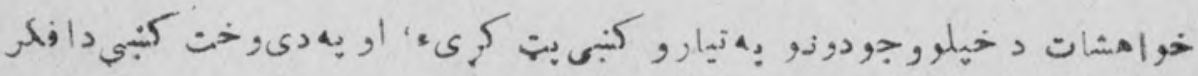




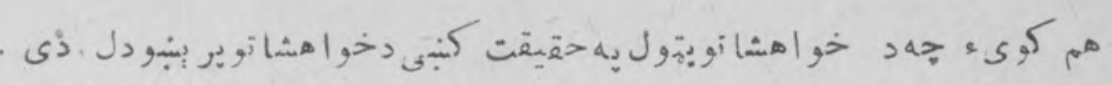

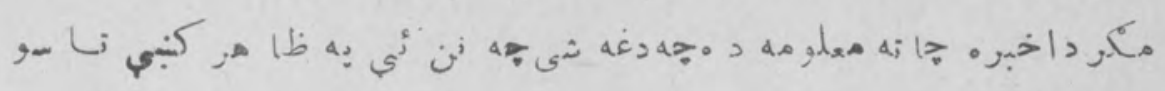

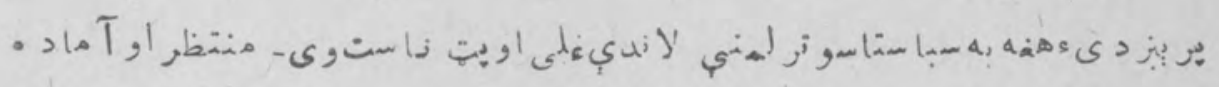

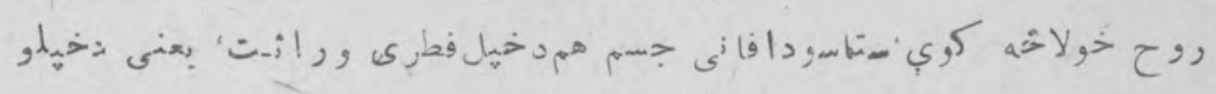

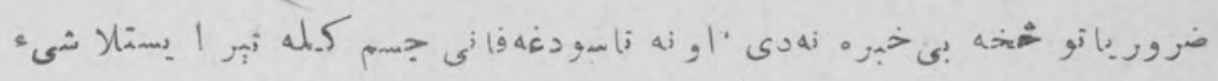

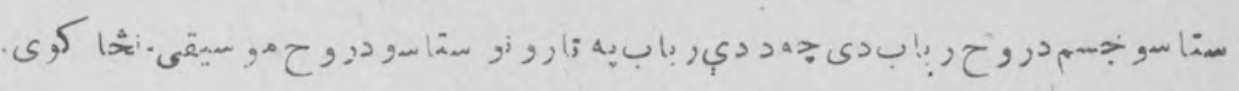

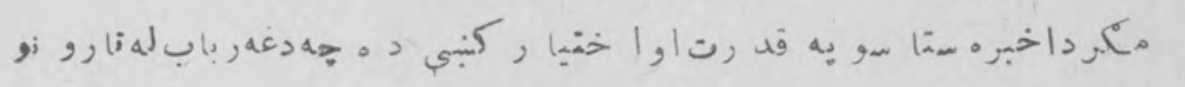

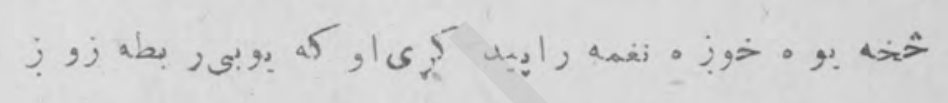

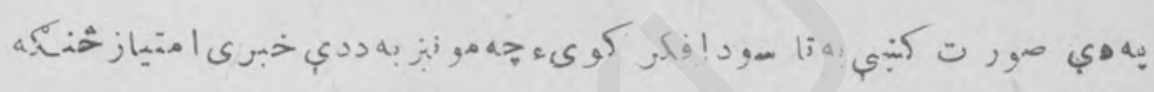

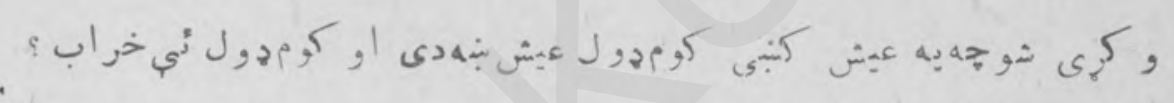

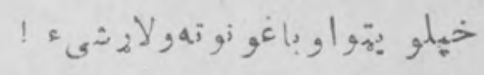

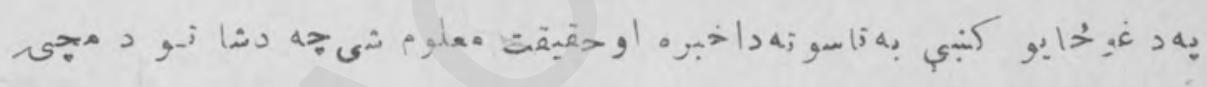

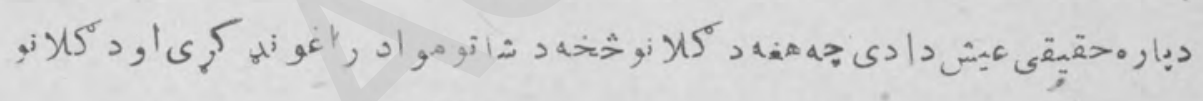

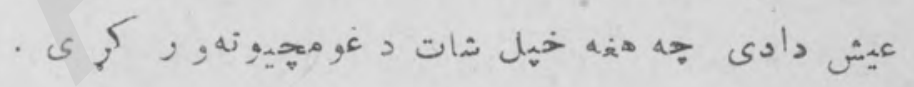

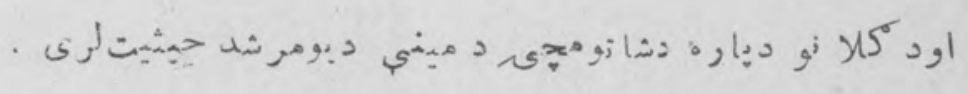

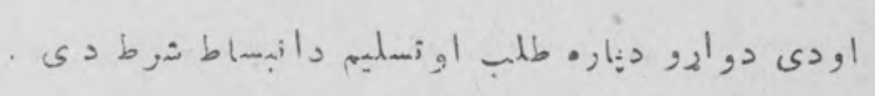

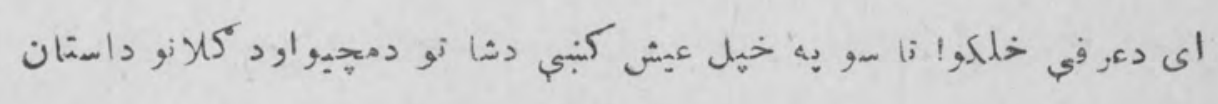




\section{$-Y \&-$}

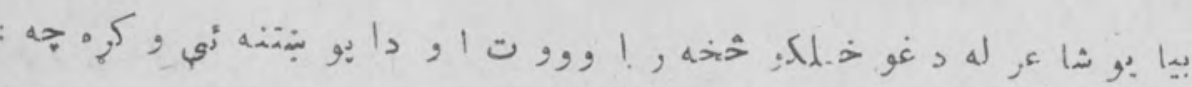

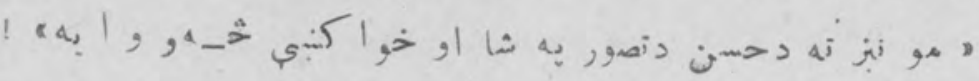

$$
\begin{aligned}
& \text { : }
\end{aligned}
$$

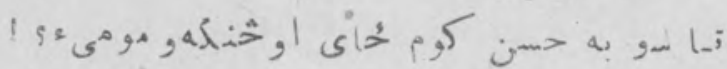

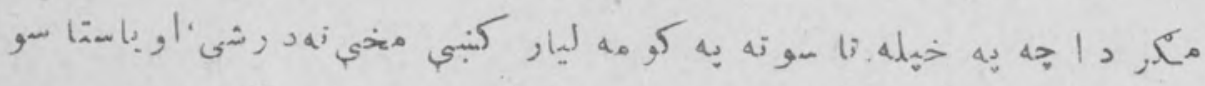

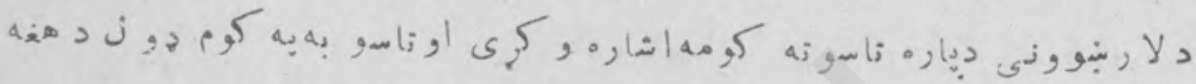

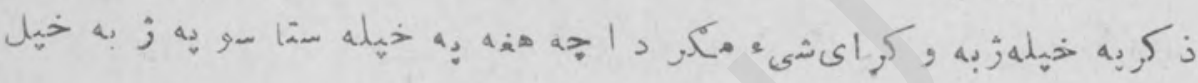

$$
\checkmark \text { \& } s, 17,12 i 5
$$

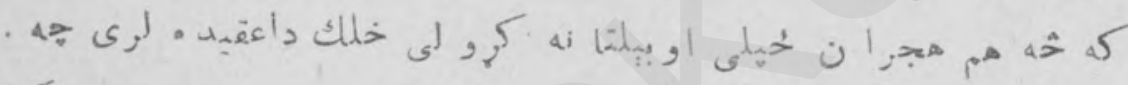

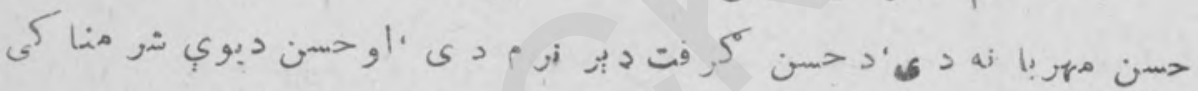

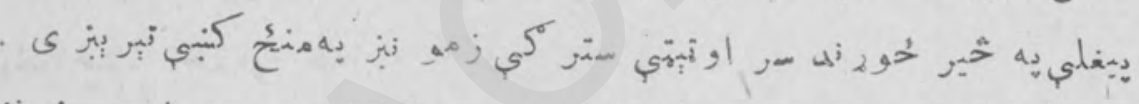
s)

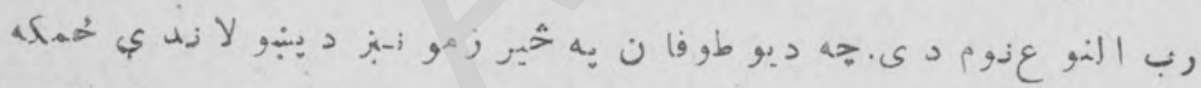

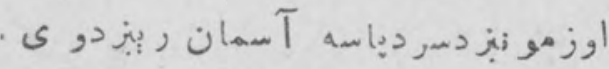

$$
\begin{aligned}
& \text { : ا }
\end{aligned}
$$

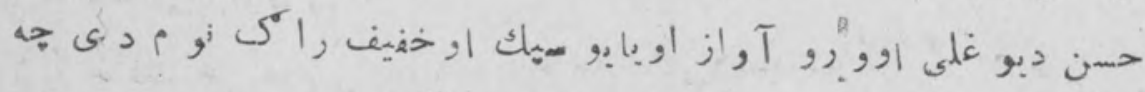

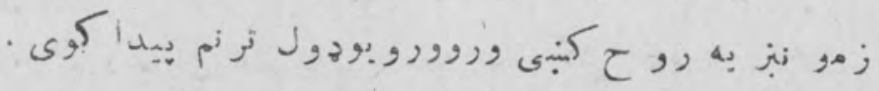

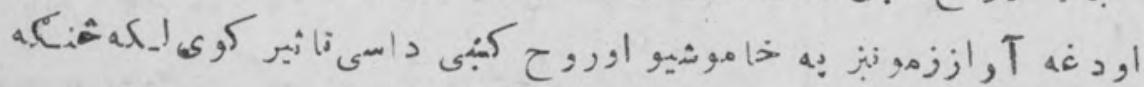

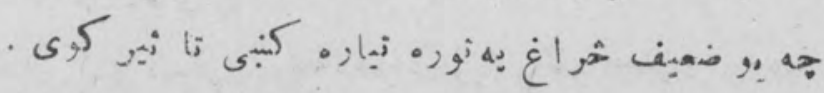




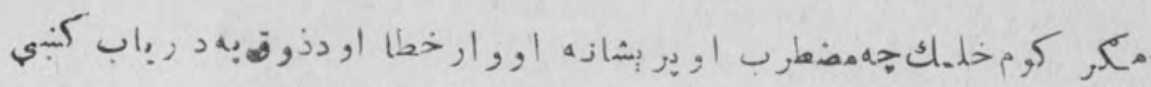

$$
\text { - : لالا }
$$

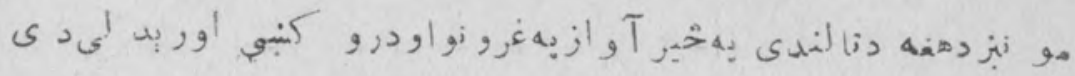

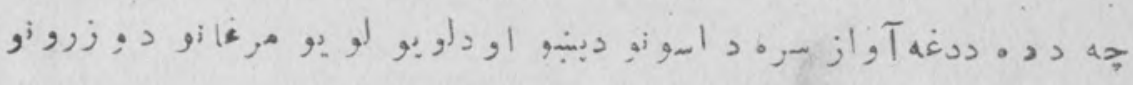

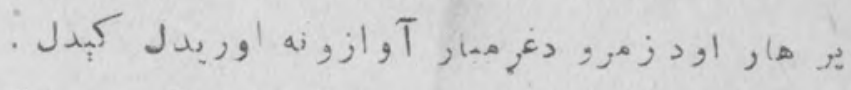

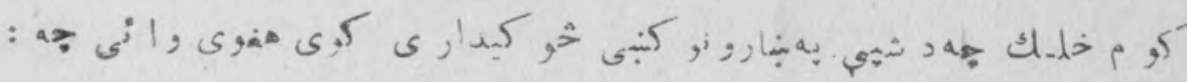

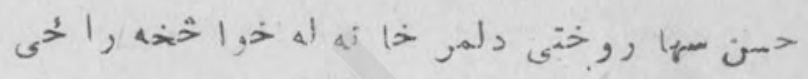

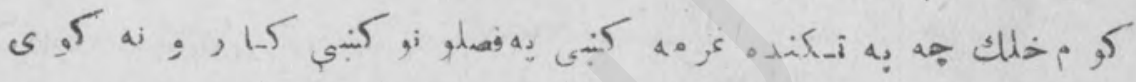

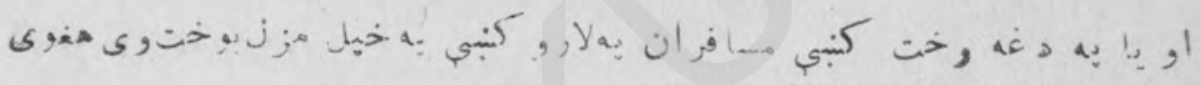
:

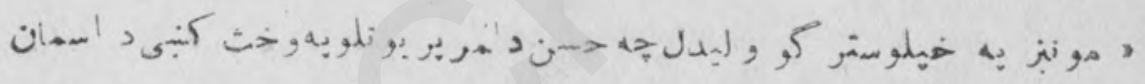
D

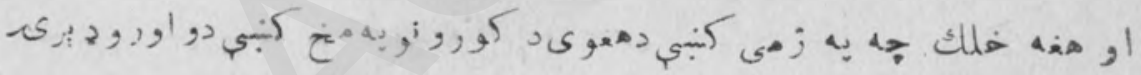

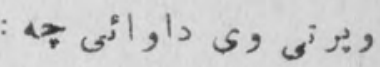

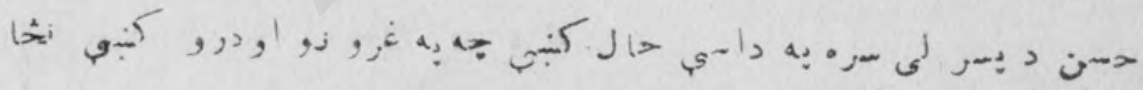

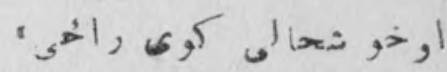

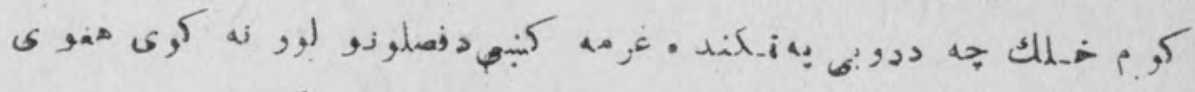

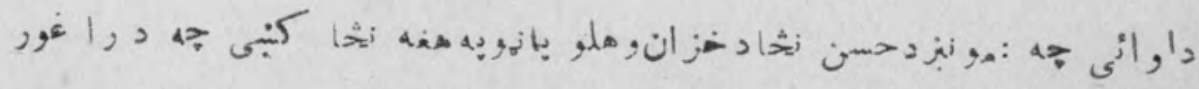

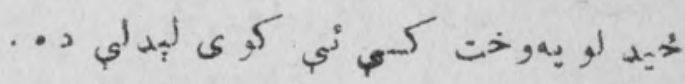

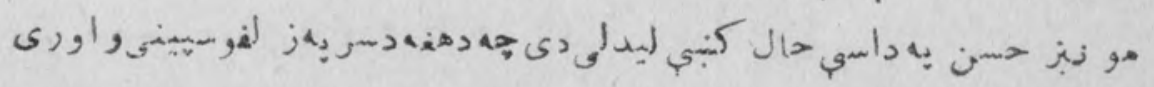


مبرتيوي .

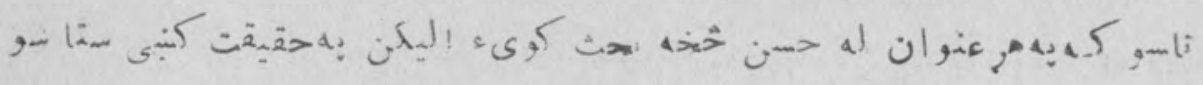

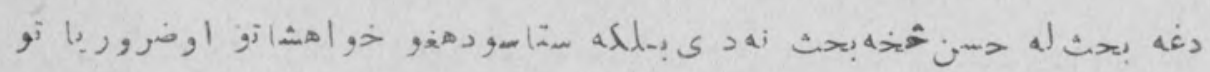

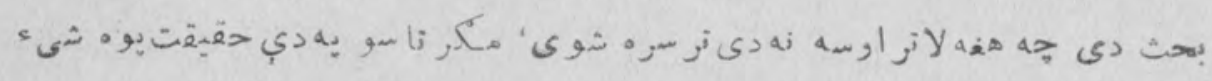

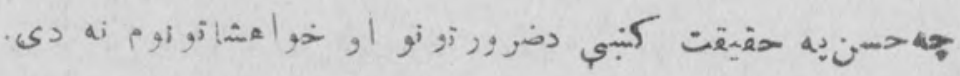

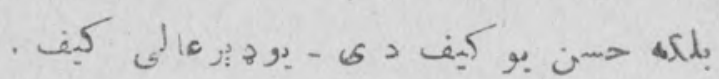

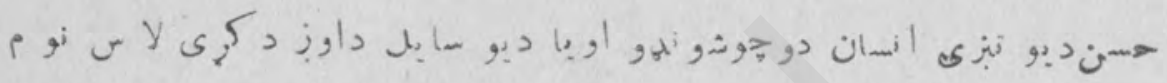

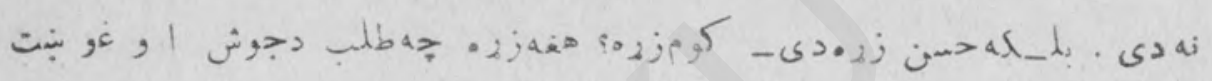

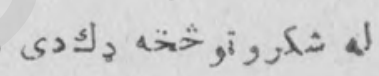

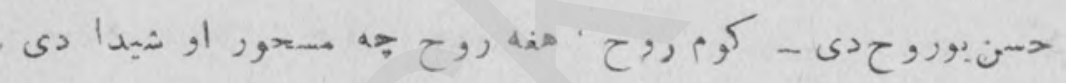

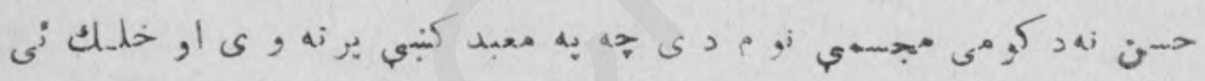

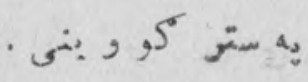

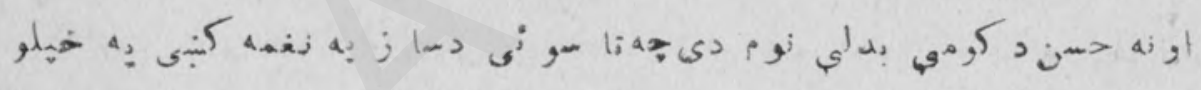

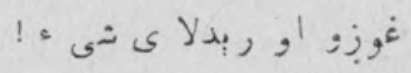

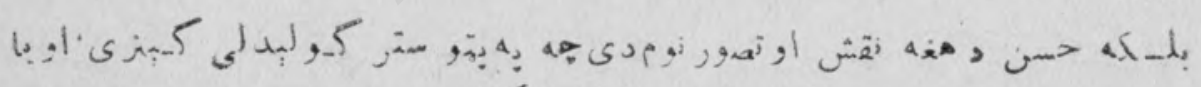

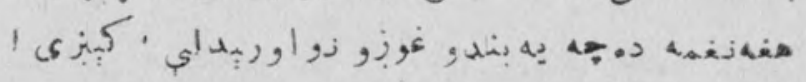

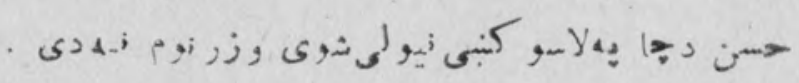

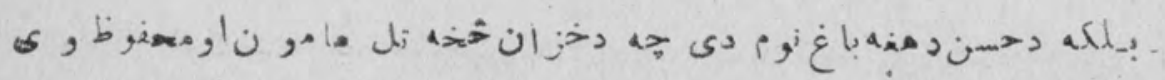

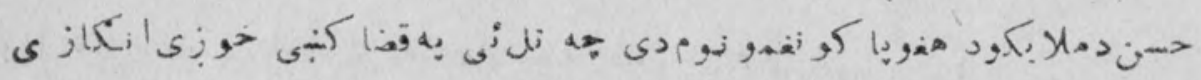




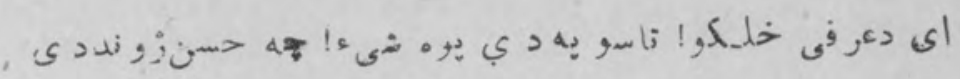

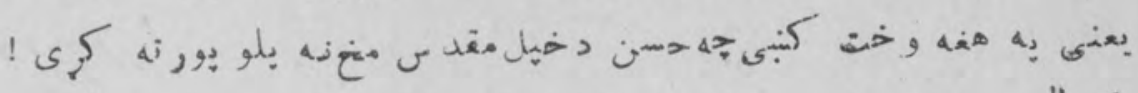

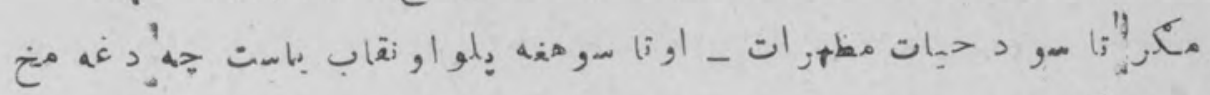

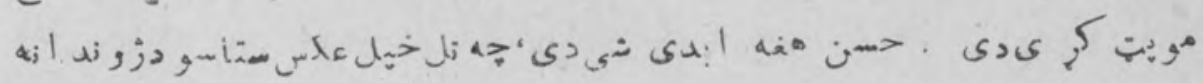

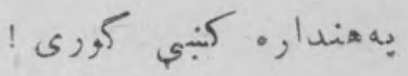

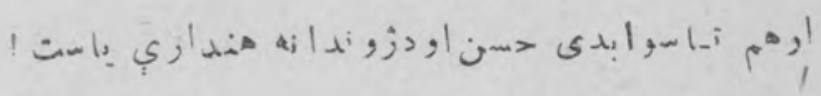

$$
\begin{aligned}
& \text { بـا يو. }
\end{aligned}
$$

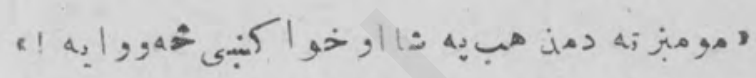

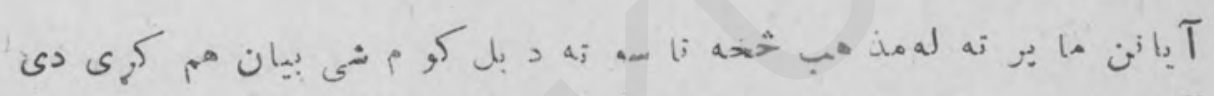

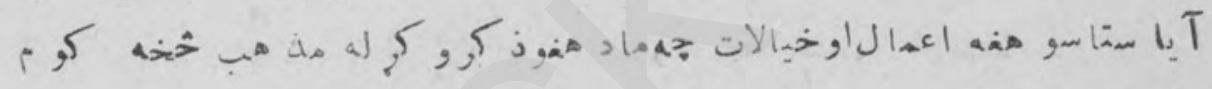

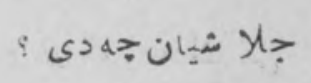

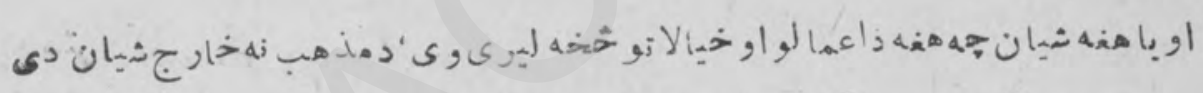

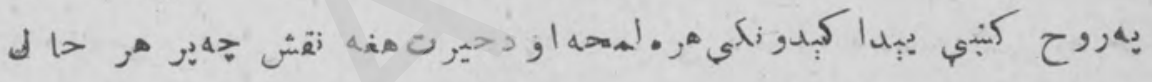

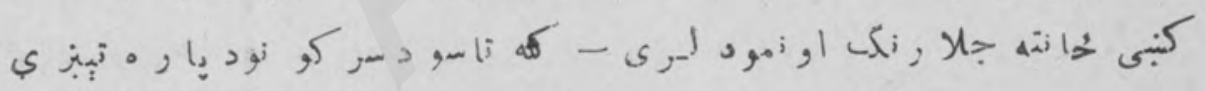

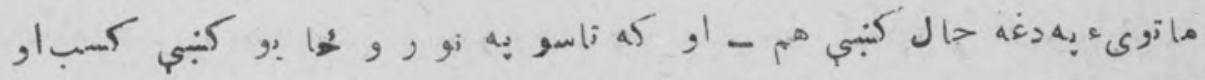

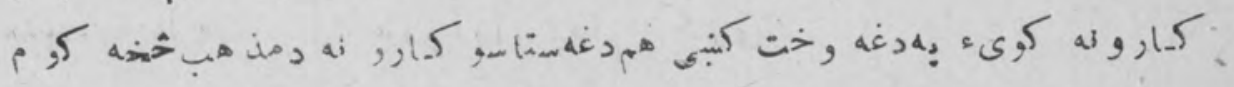

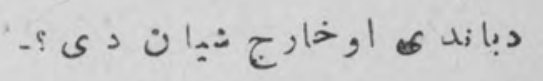

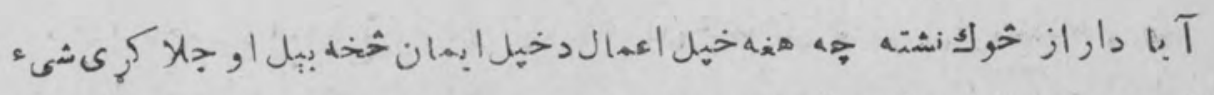

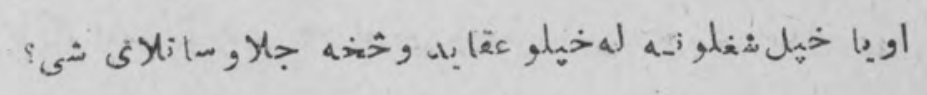




\section{\&az}

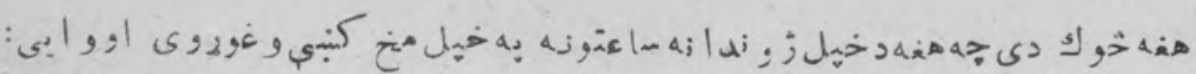

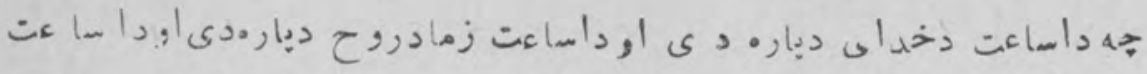
زما د جسم د ب! رودى.

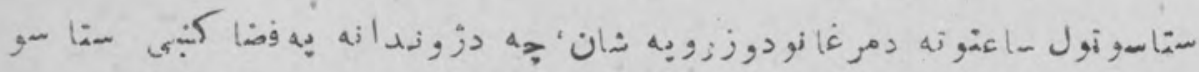

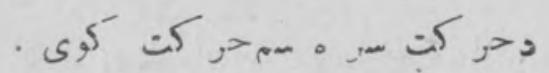

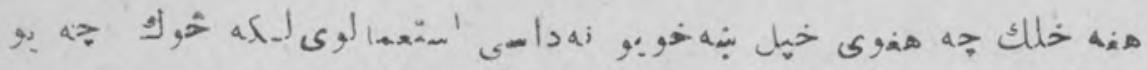

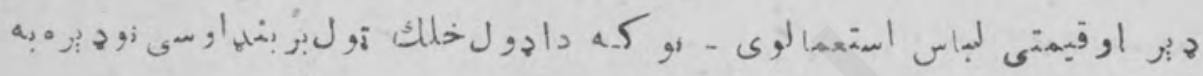
بنهوى

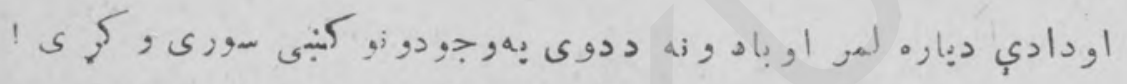

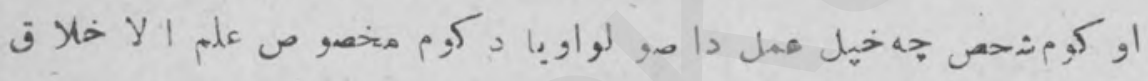

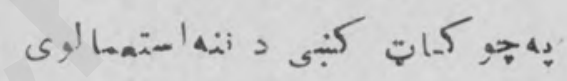

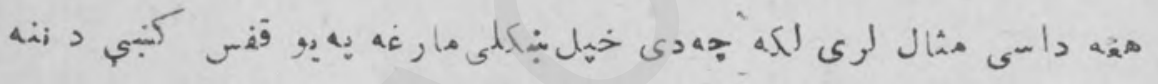

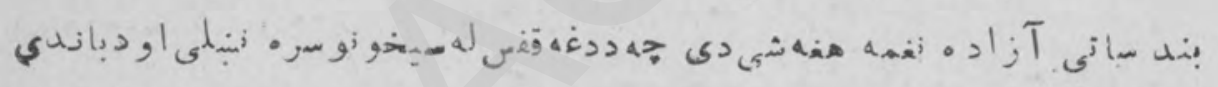
जे,

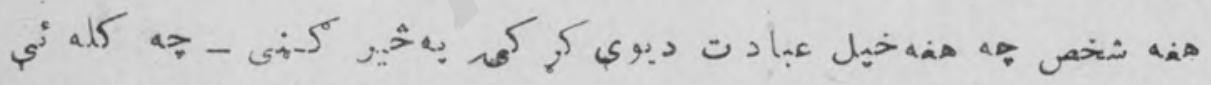

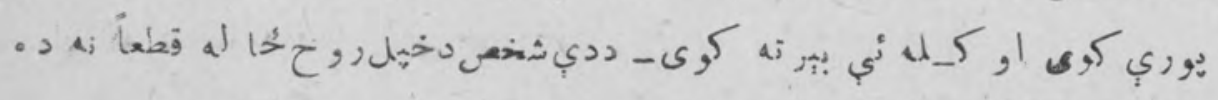

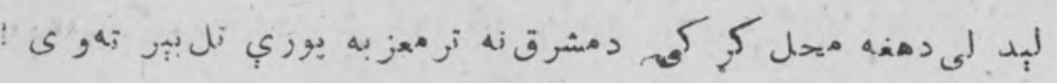

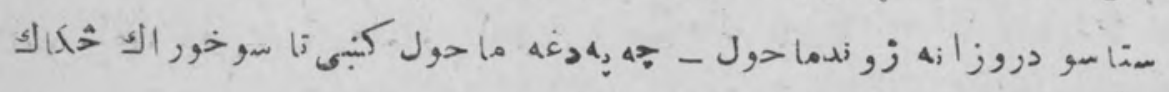

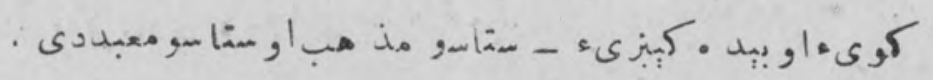

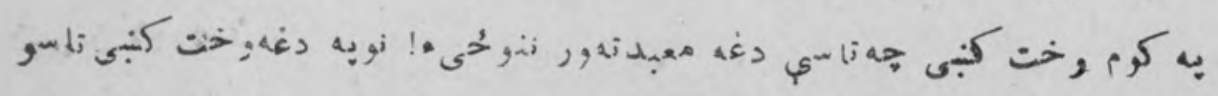




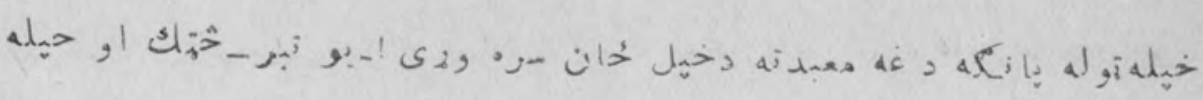
oldis

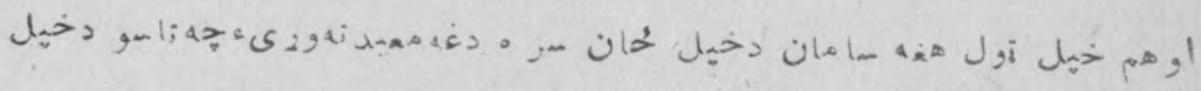

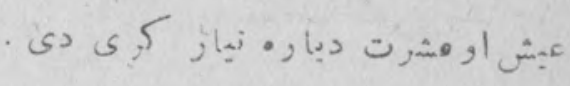

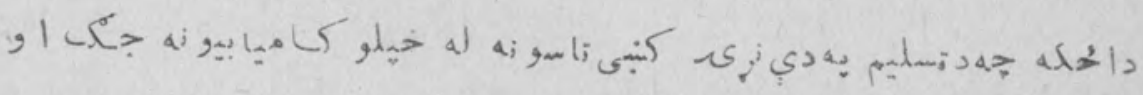

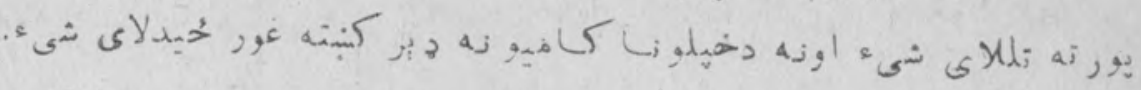

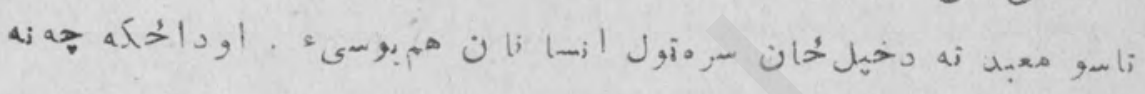

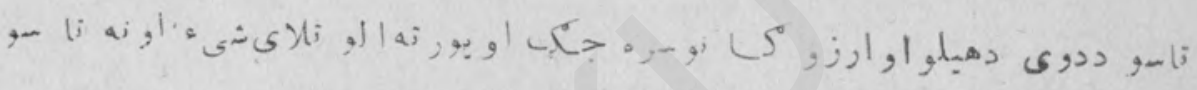

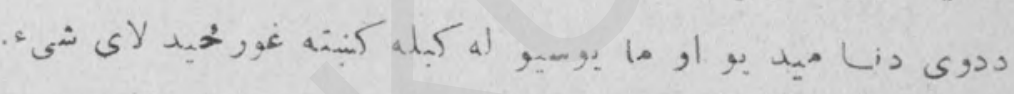
كان أla 10 a d a a a

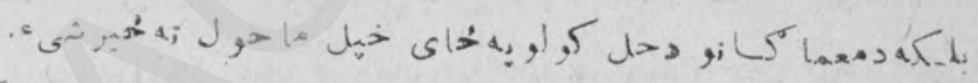

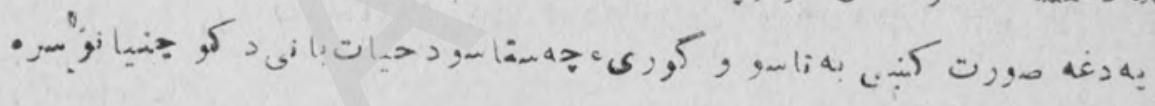

$$
\begin{aligned}
& \text { ! ب }
\end{aligned}
$$

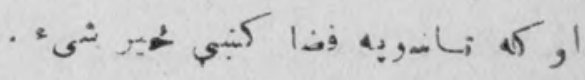

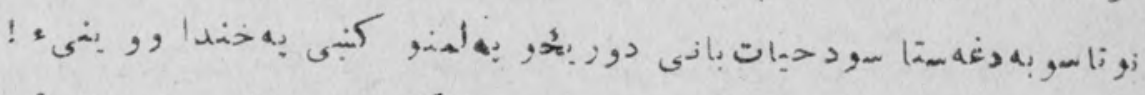

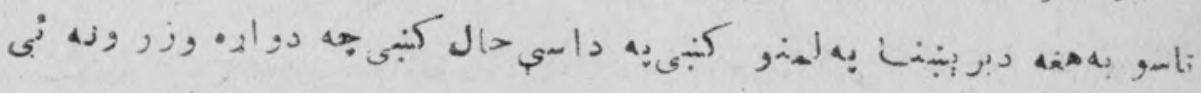

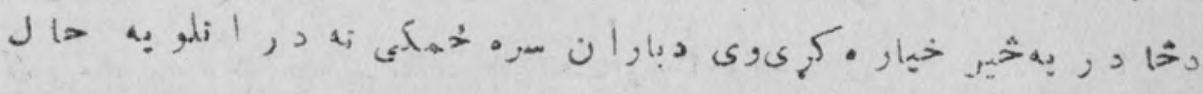
ك 


\section{(1.)}

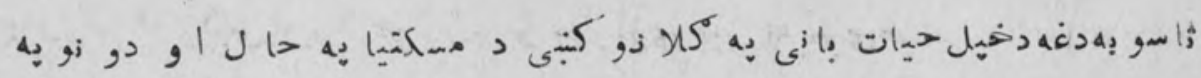

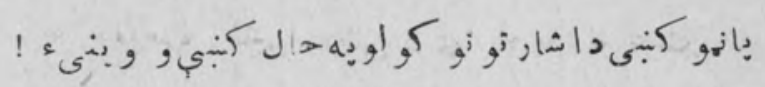

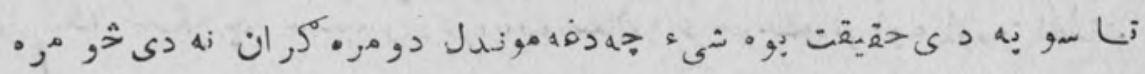

$$
\text { v } 0 \text { s }
$$

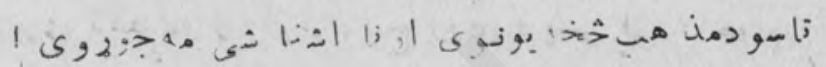

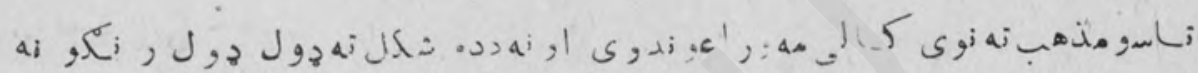

$$
\text { ! } 1 \text {, }
$$

S

$$
\text { ! ج }
$$

$$
\text { “ }
$$

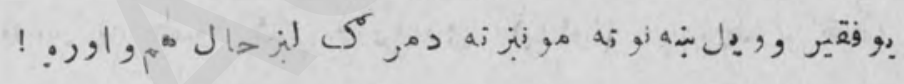

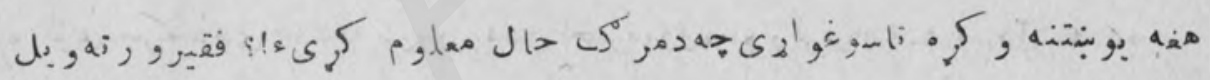

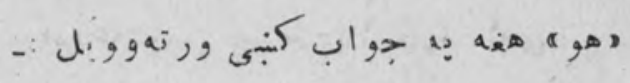

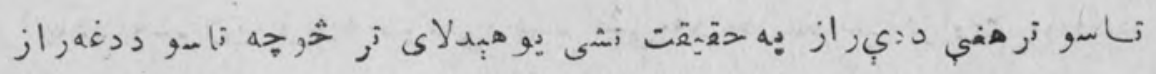

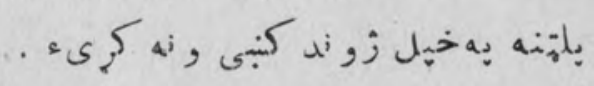

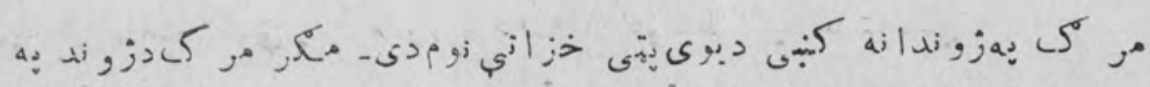

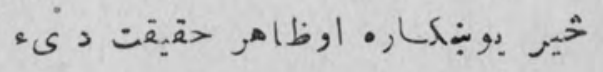

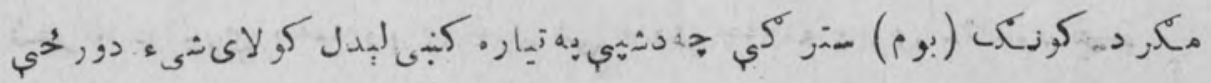

$$
\text { \& ش }
$$

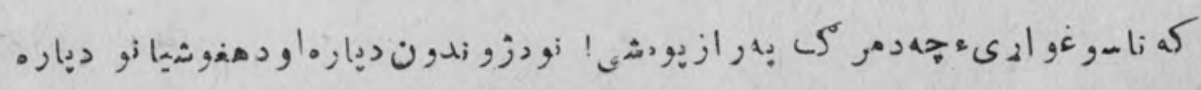




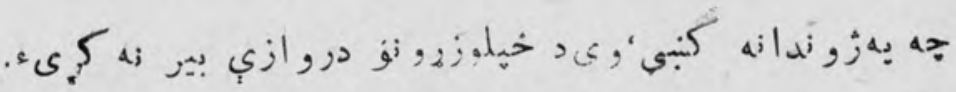

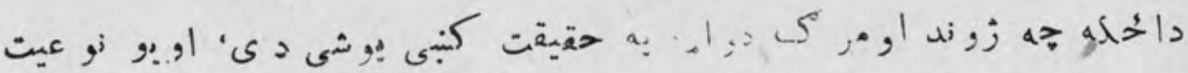

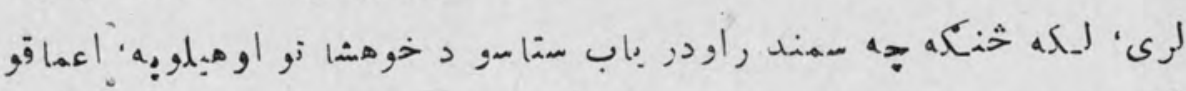

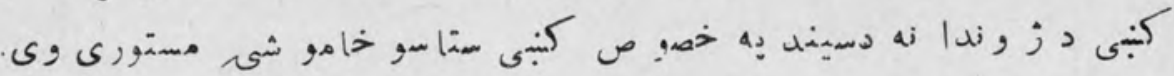

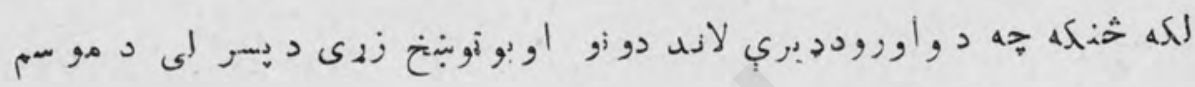
خو بو نه و بنى.

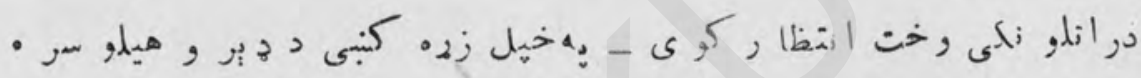

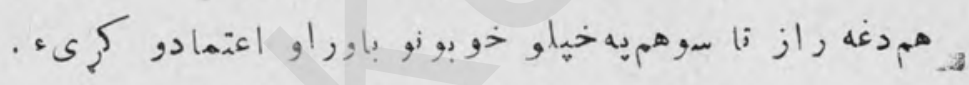

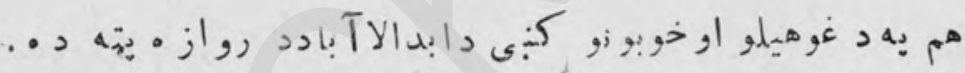

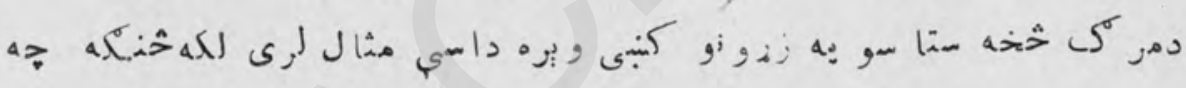

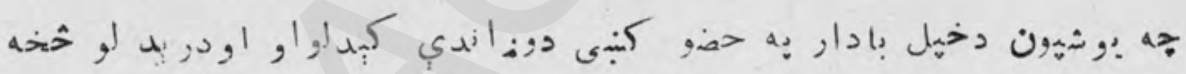

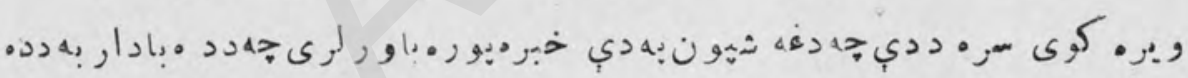

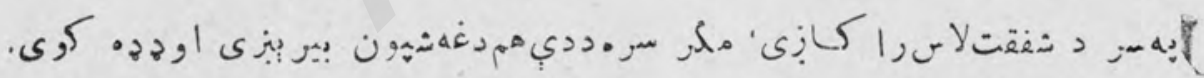

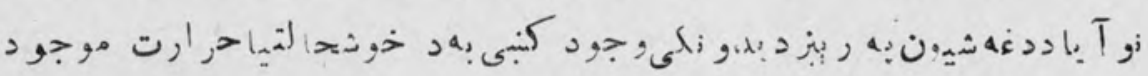
s $ى$, 4

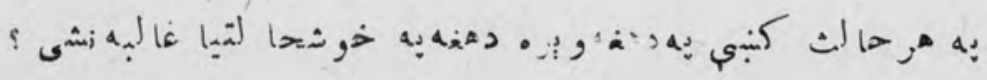

$$
\text { م. }
$$

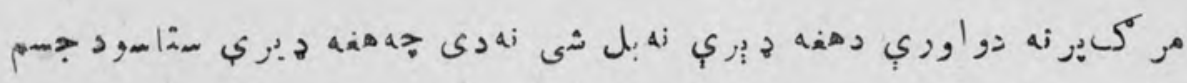

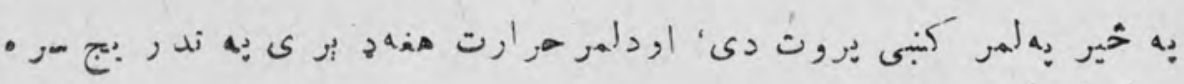

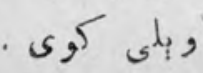




\section{(Ar)}

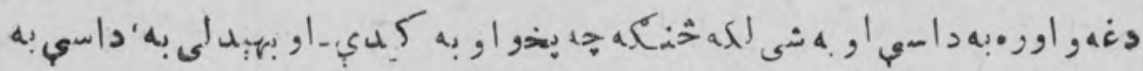

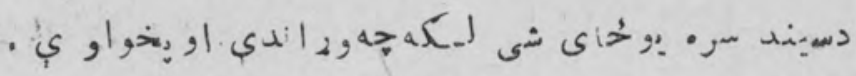

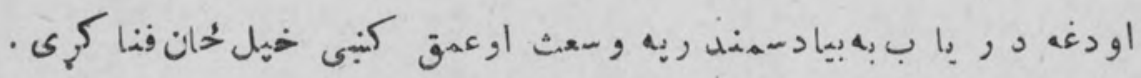

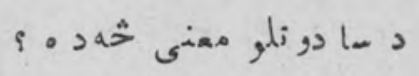

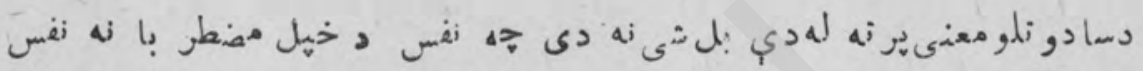

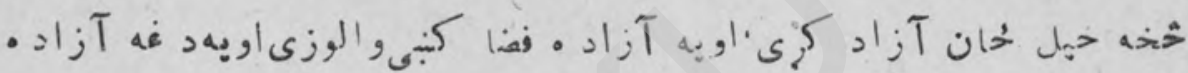

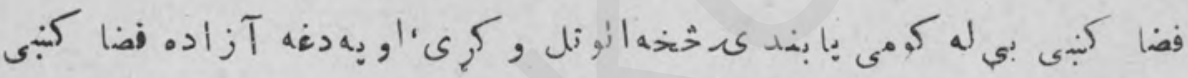

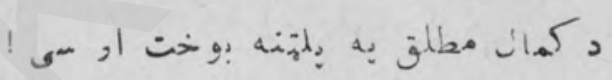

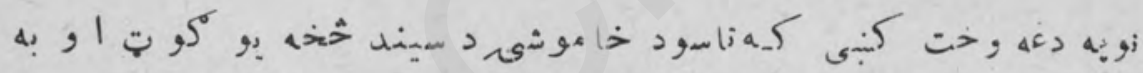

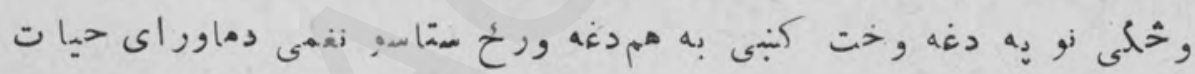

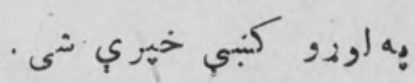

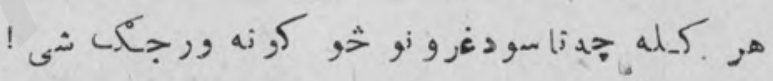

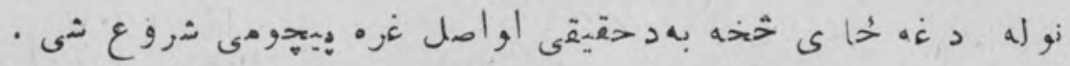

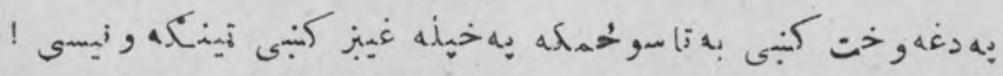

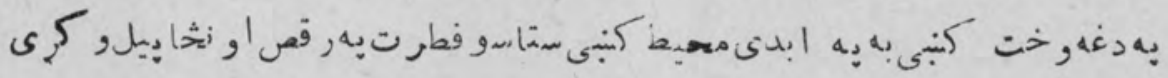
-(ve)

$$
\begin{aligned}
& \text { به دي خبرو كنبىمانبام شو . } \\
& \text { عارفى ووبل : }
\end{aligned}
$$

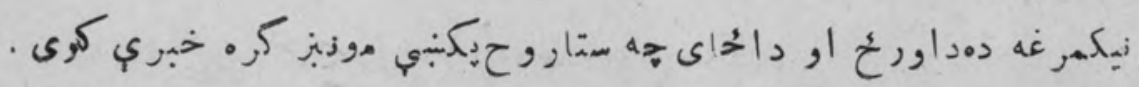




\section{(A)}

$:$ : ه

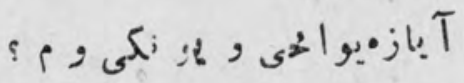

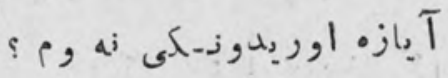

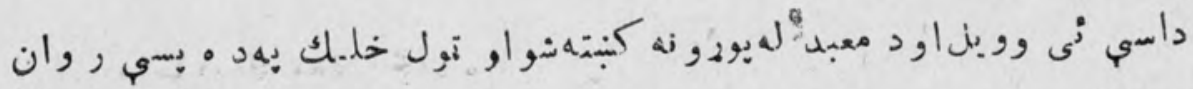

$$
\begin{aligned}
& \text { شول اودى خهل جه!|زه ور ورسيد . }
\end{aligned}
$$

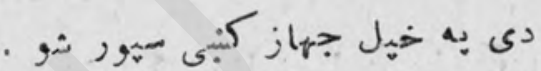

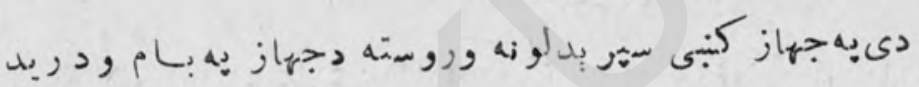

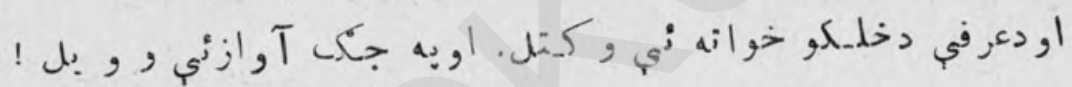

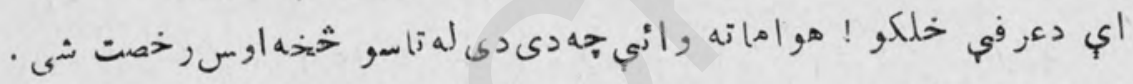

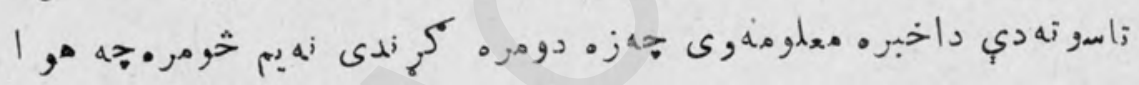

$$
\text { . . } 02
$$

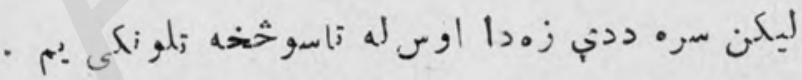

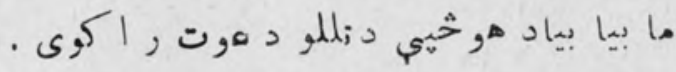

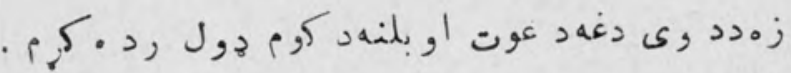

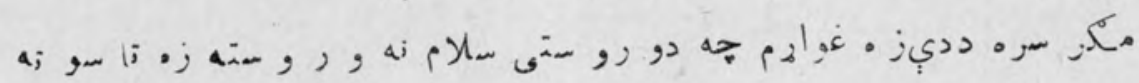

$$
\text { . }
$$

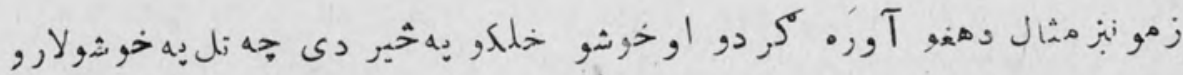

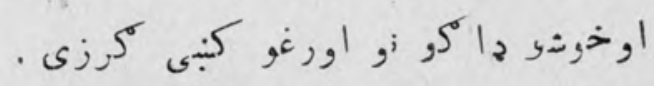

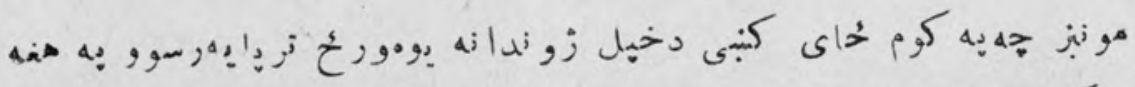
. 


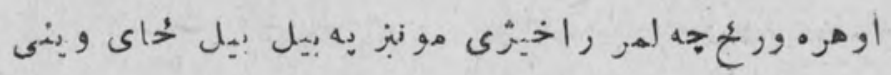

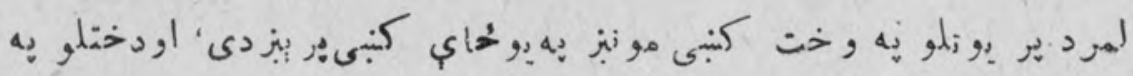

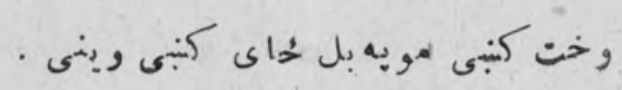

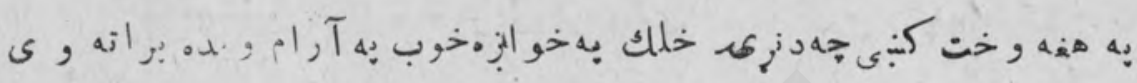

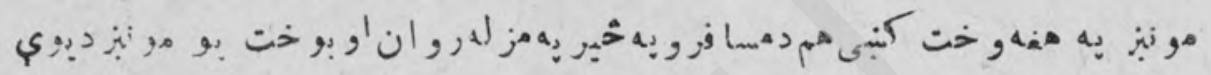

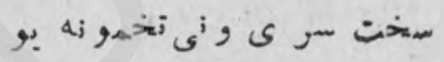

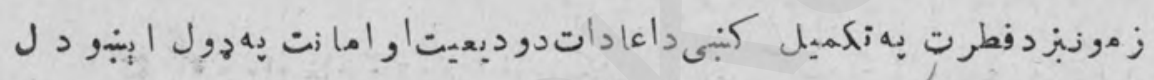

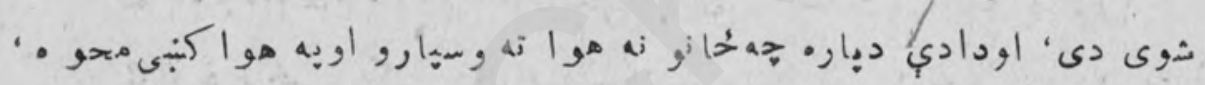

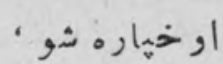

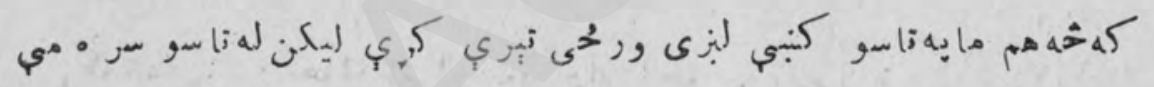

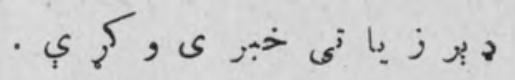

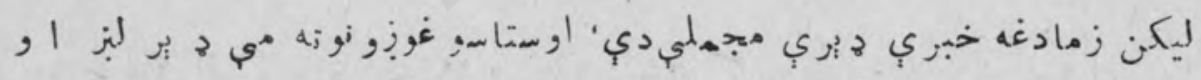

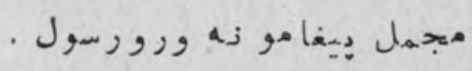

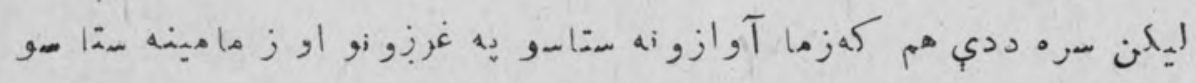

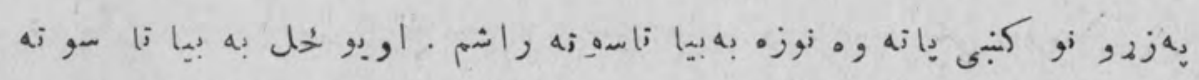

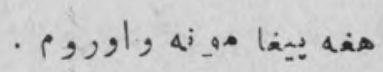

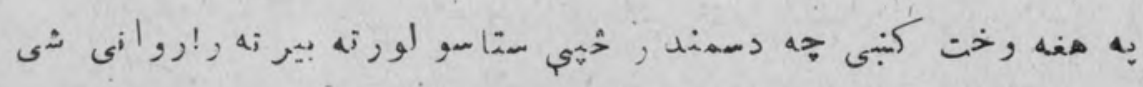

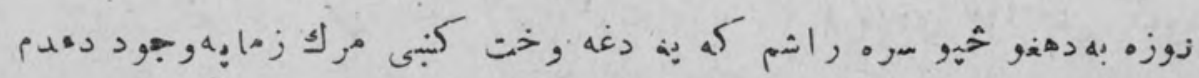

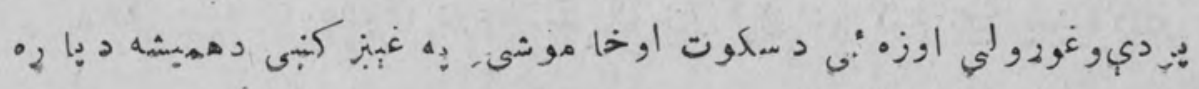




\section{(10)}

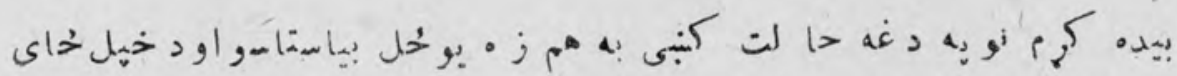

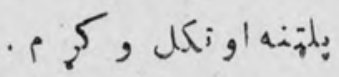

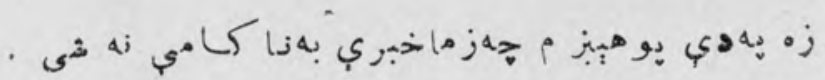

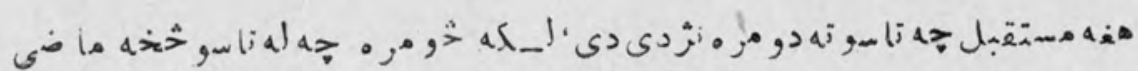

. o s

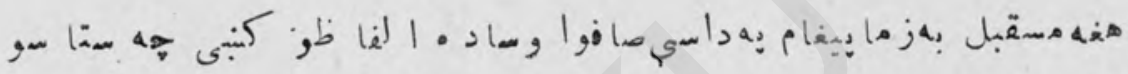

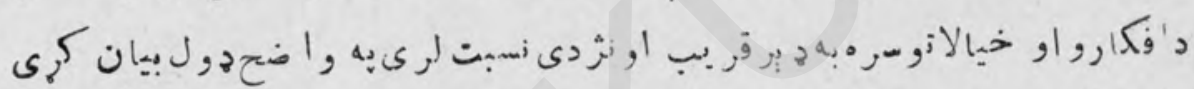

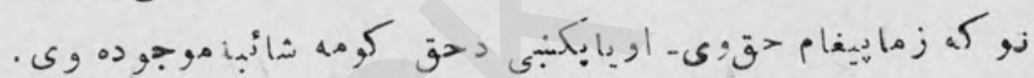

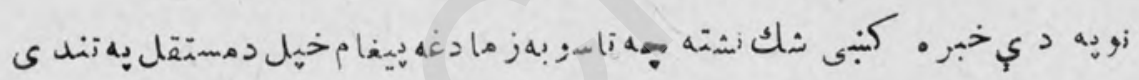

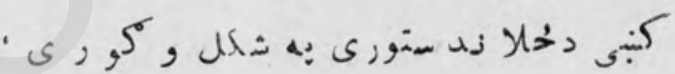

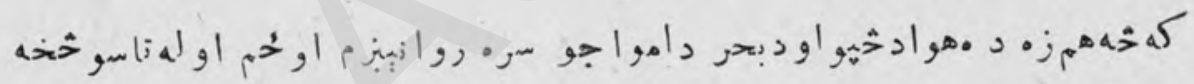
ج

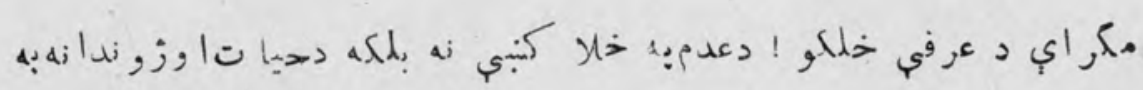

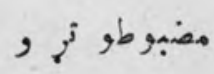

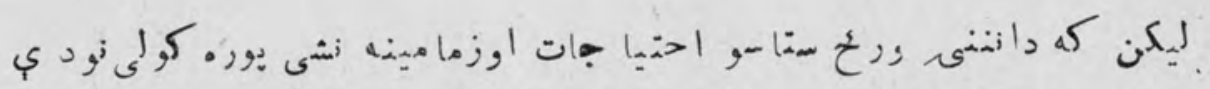

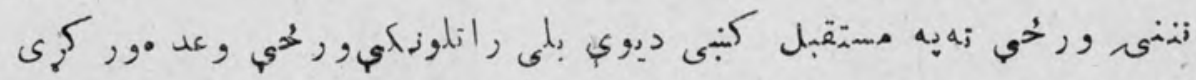

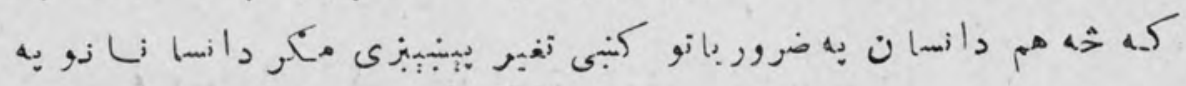

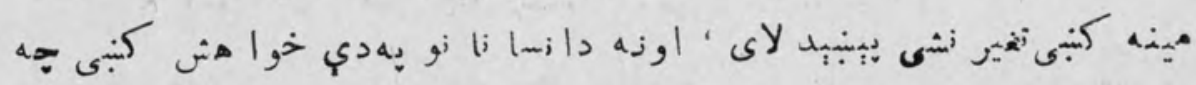

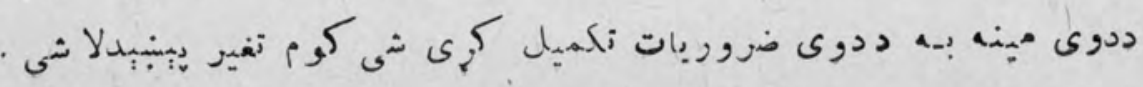




\section{(1)}

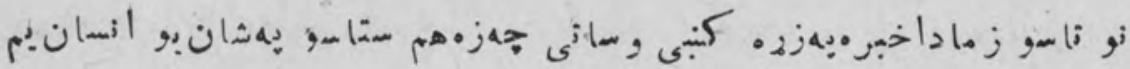

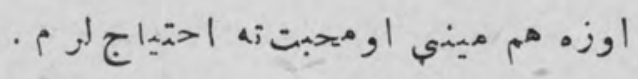

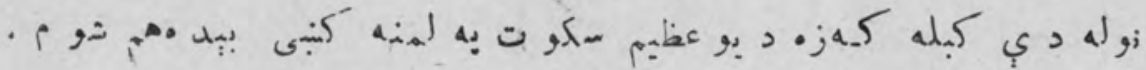

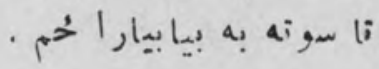

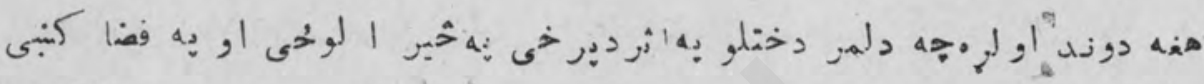

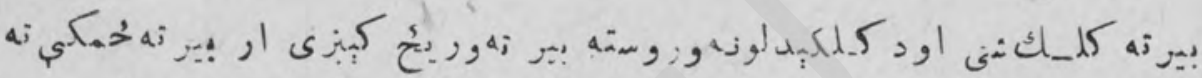

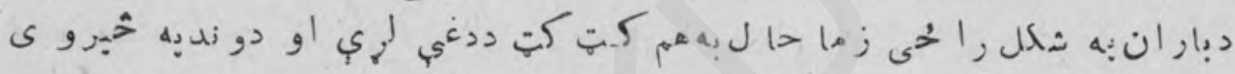

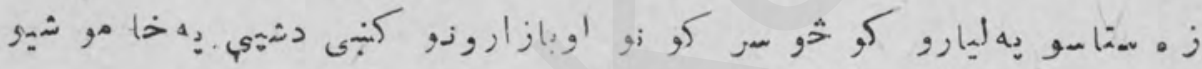

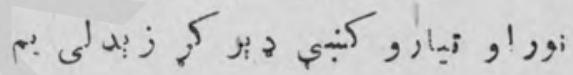

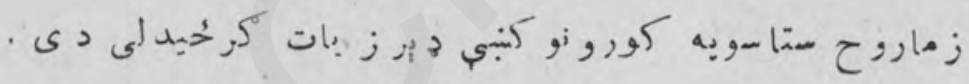

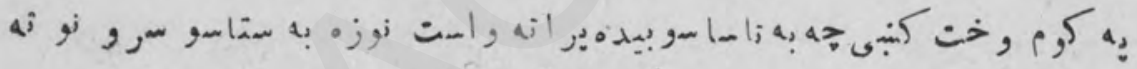

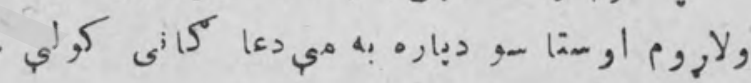

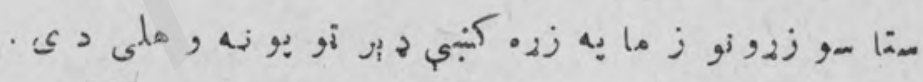

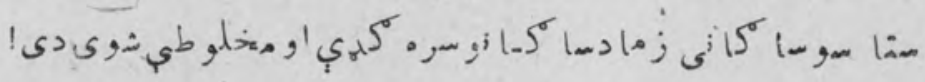

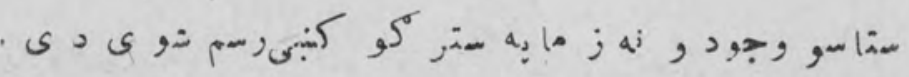

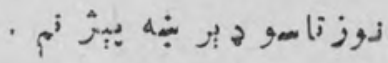

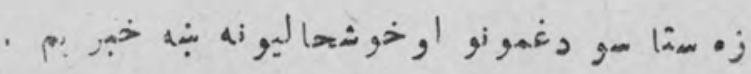

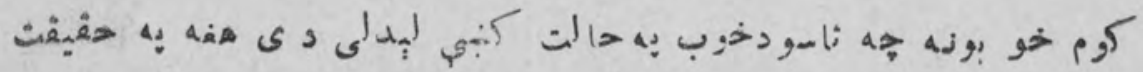

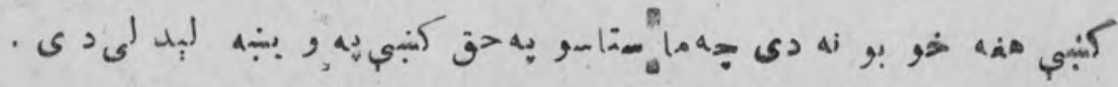

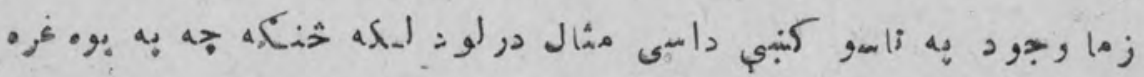

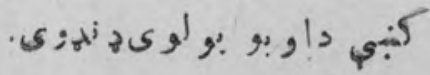




\section{(^v)}

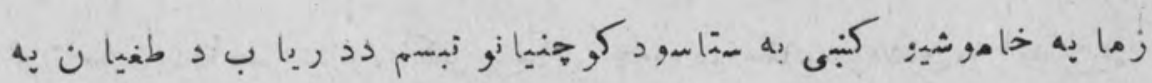

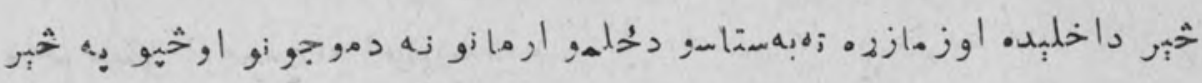

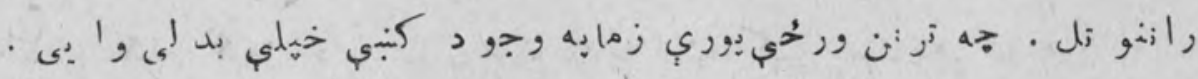

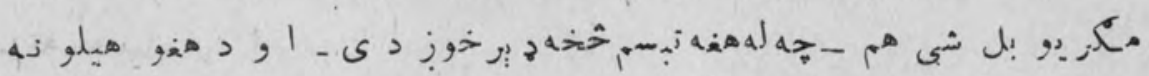

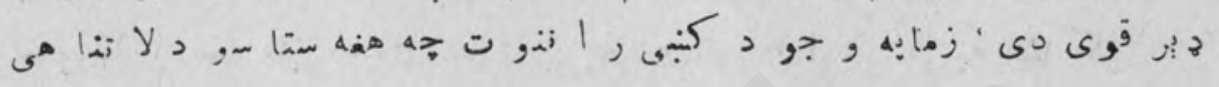

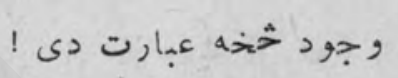

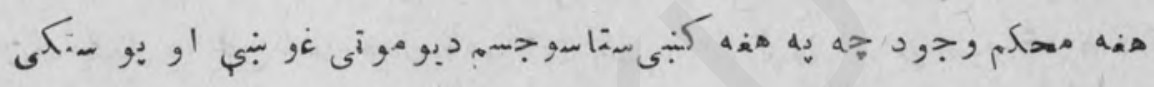
حيثيت لر منه

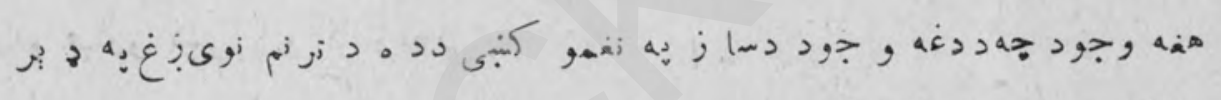

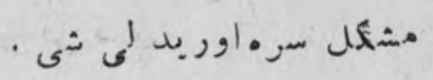

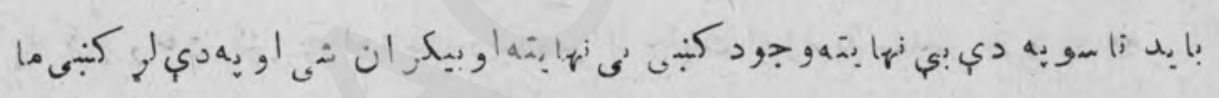

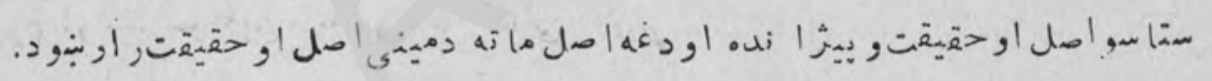

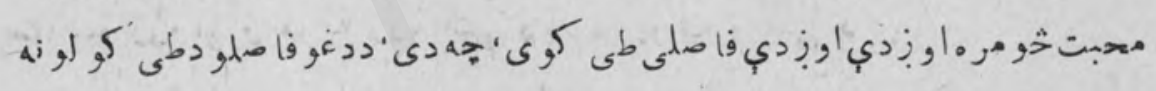

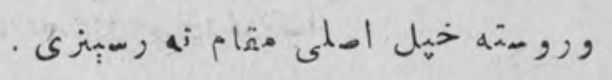

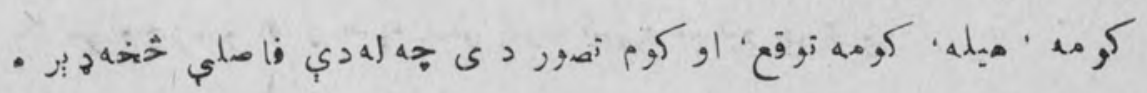

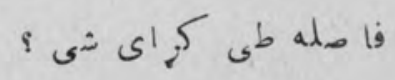

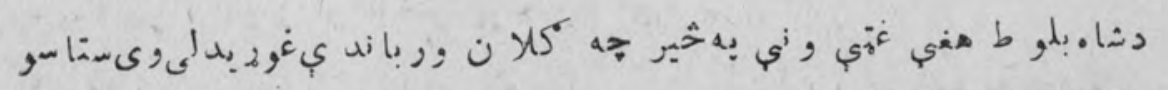

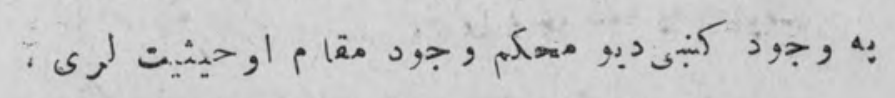

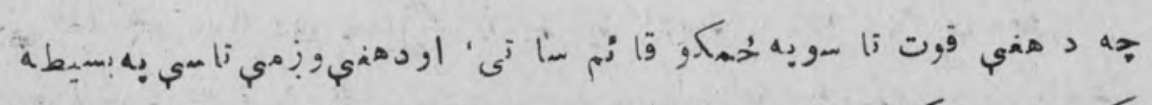
فضا كنبى بور ته كوى . 


\section{*1}

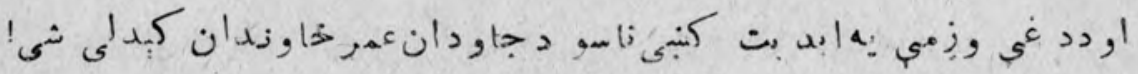

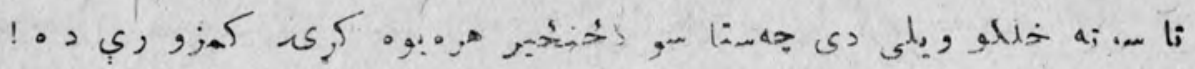

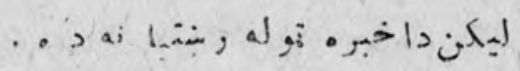

-

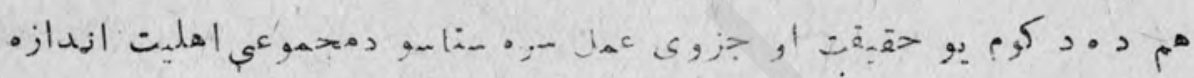
ك

$$
\begin{aligned}
& \text { - } 55
\end{aligned}
$$

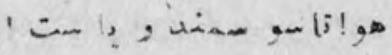

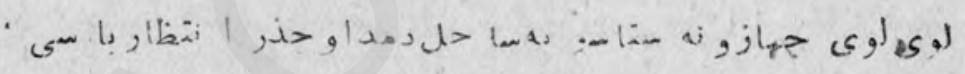

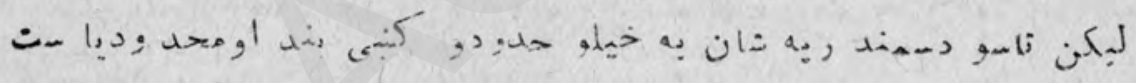

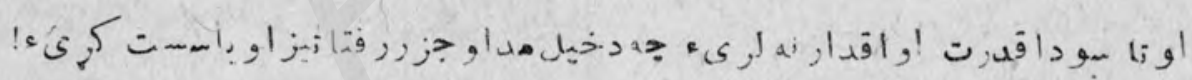

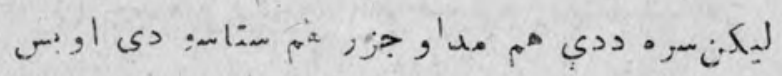

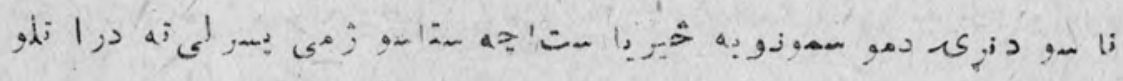

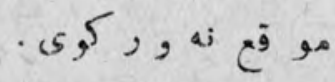

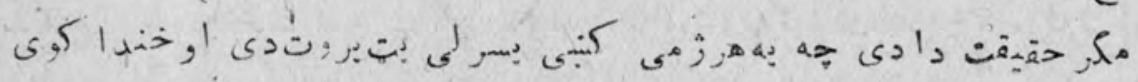

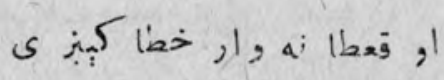

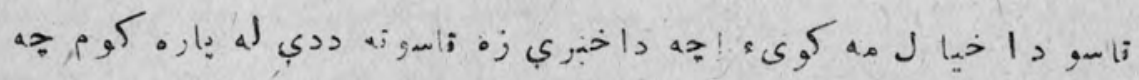

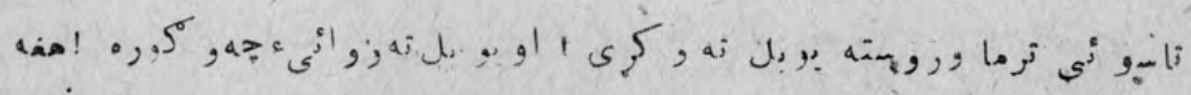

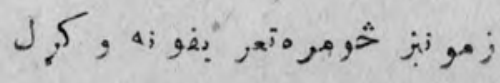




\section{$4 \cdot+$}

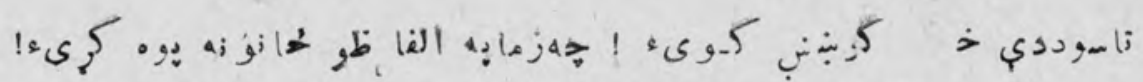

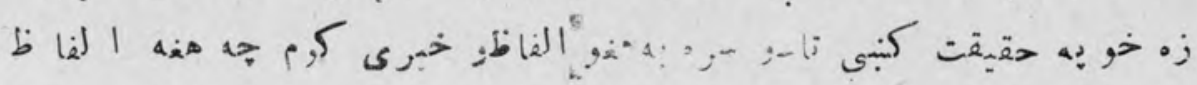

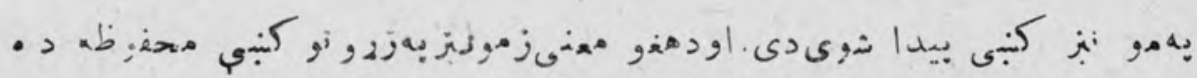

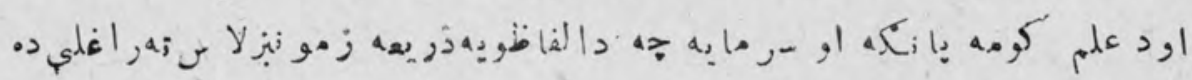
i ؟

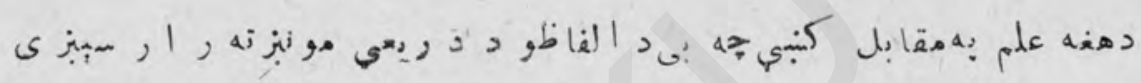

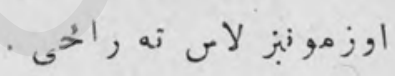

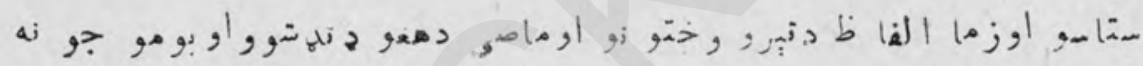

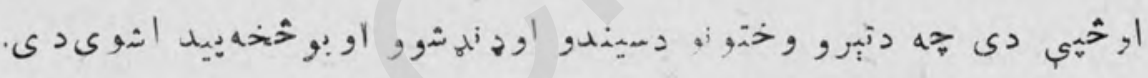

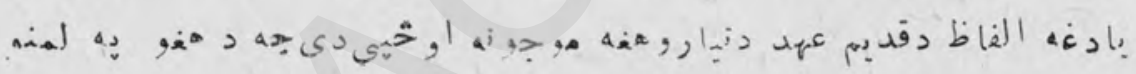

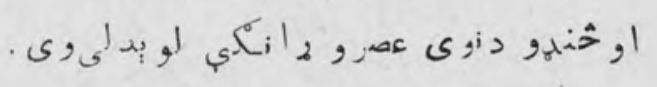

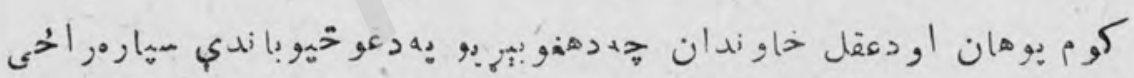

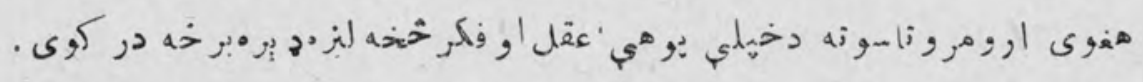

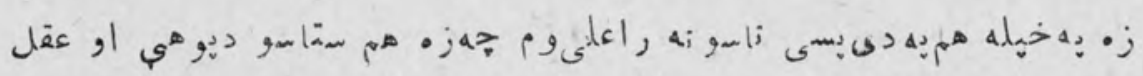

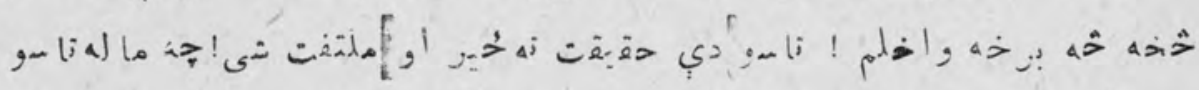

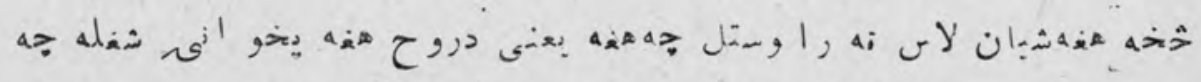

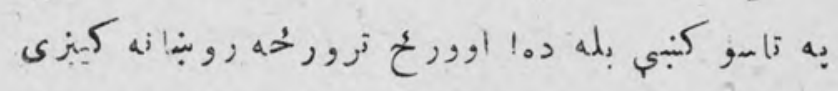

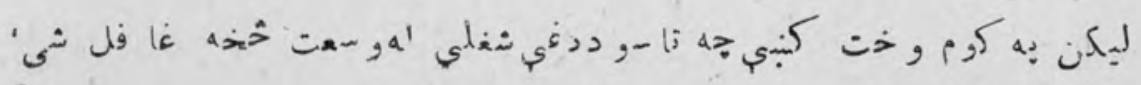
ا 


\section{(4.)}

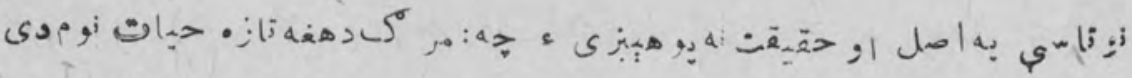

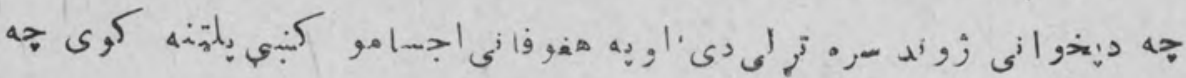

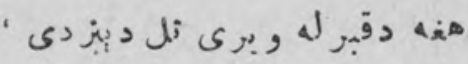

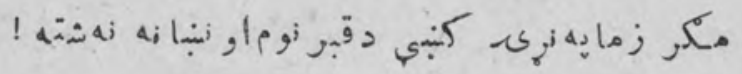

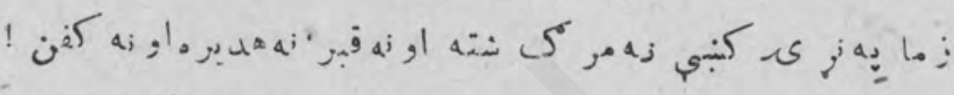

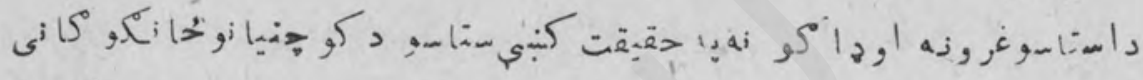

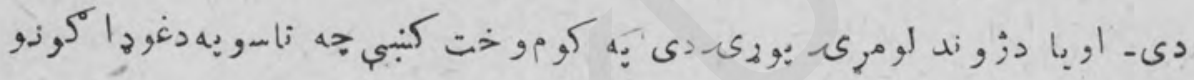

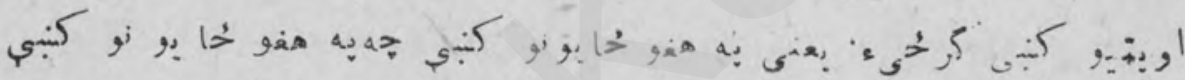

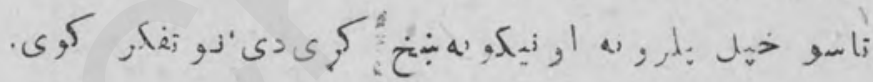

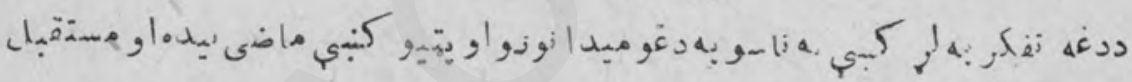

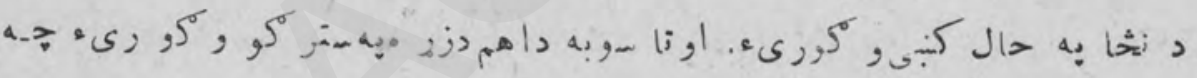

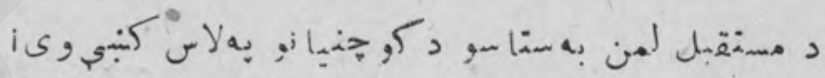

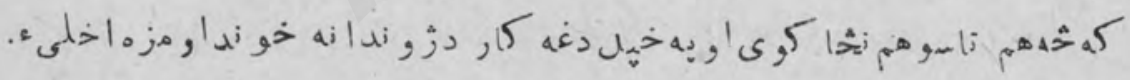

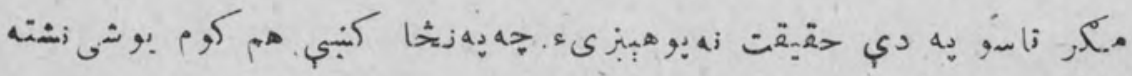

$$
\begin{aligned}
& \text { - }
\end{aligned}
$$

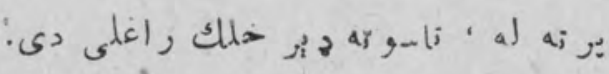

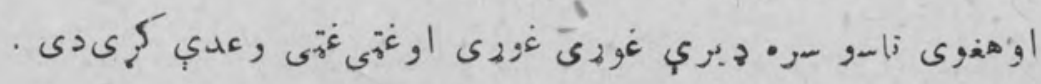

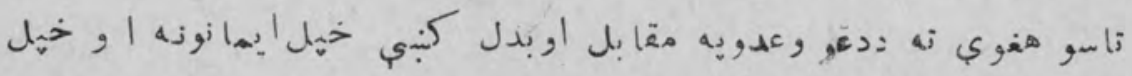

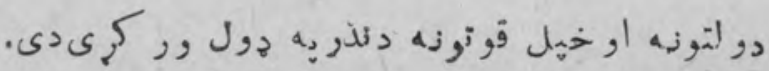

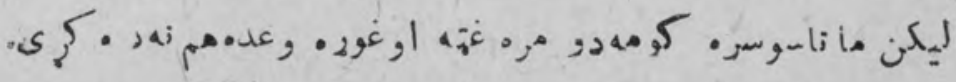




\section{(2)}

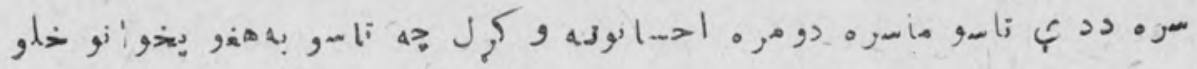

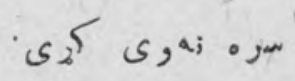

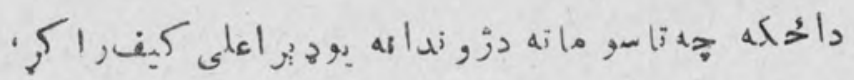

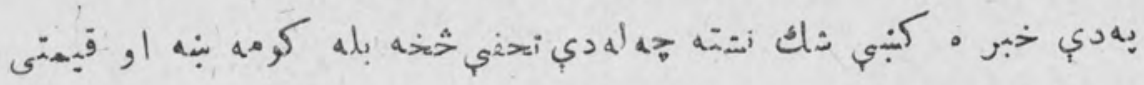

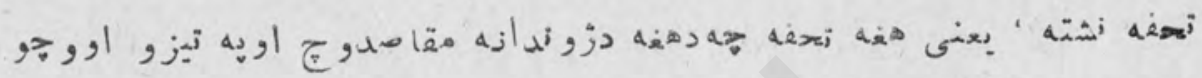

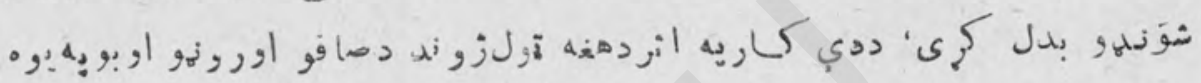

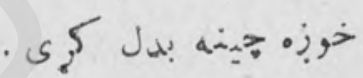

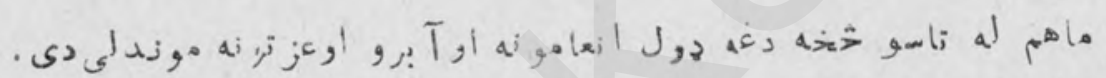

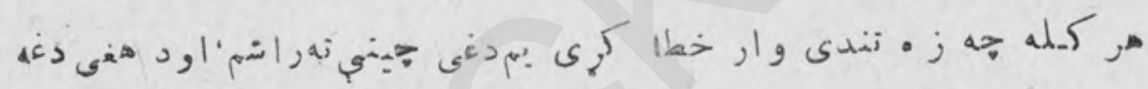

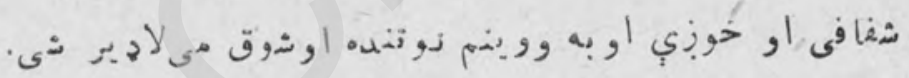

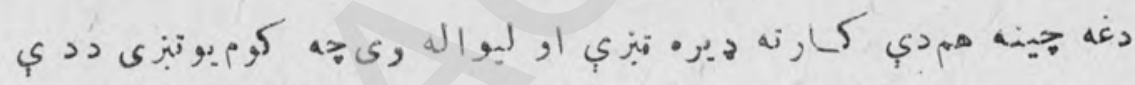
ا إبه ,

$$
\text { ! }
$$

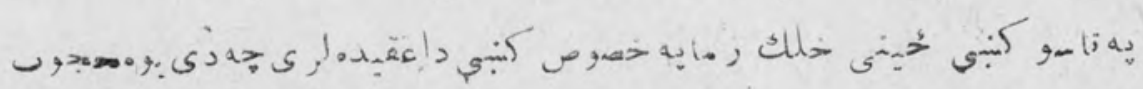

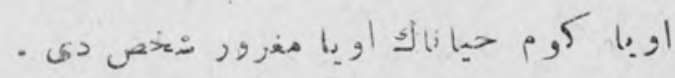

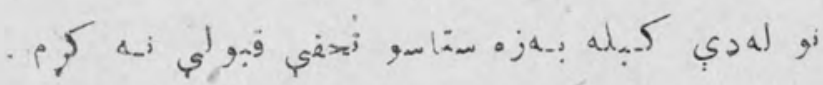

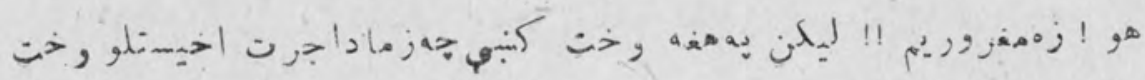

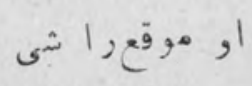

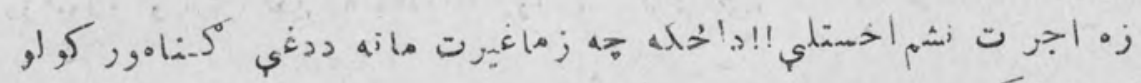

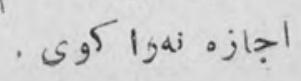




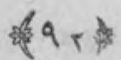

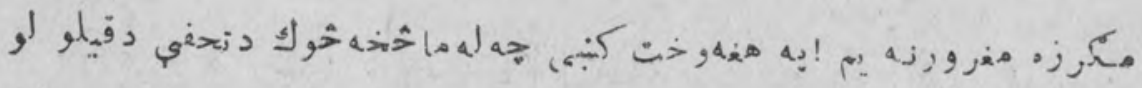

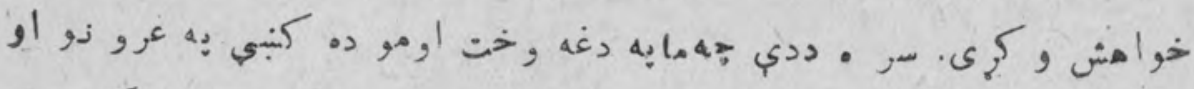

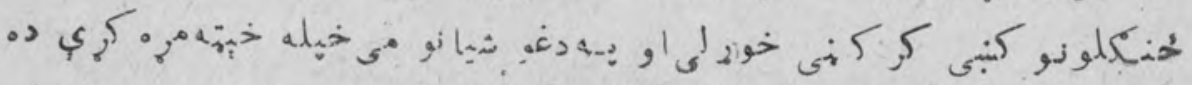

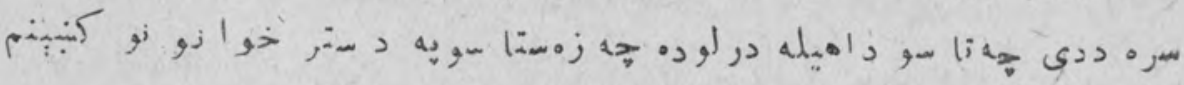

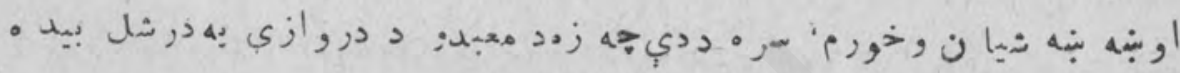

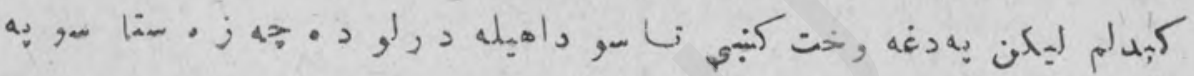

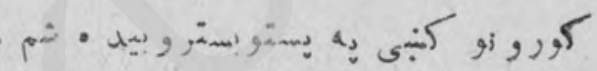

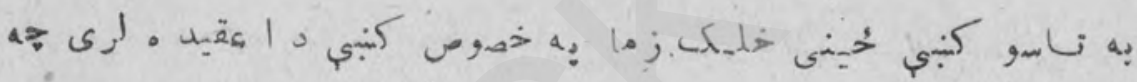

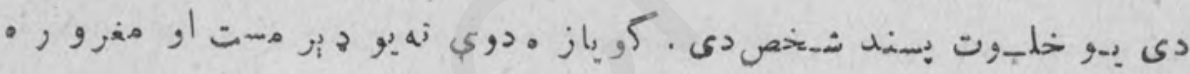
شخس بندار بذيزما

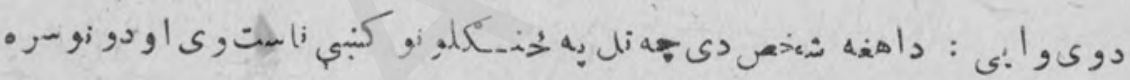

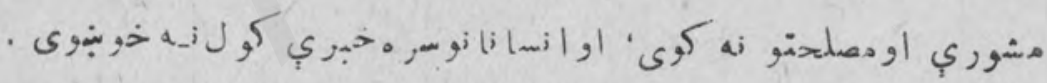

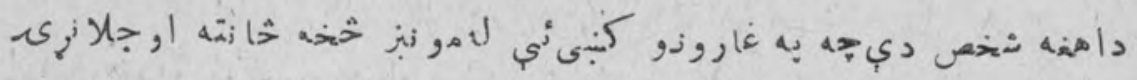

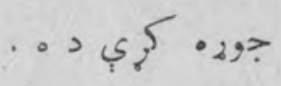

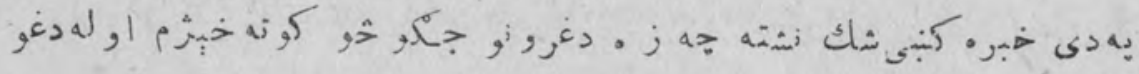

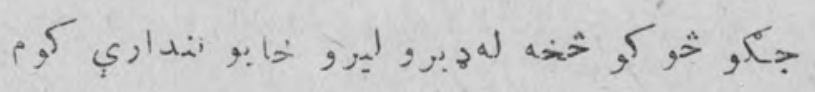

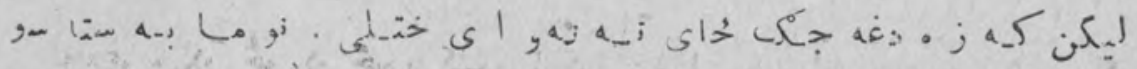

لها

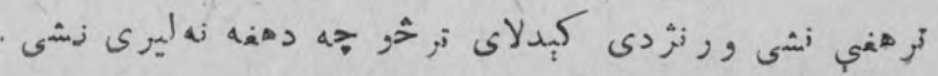




\section{(ar)}

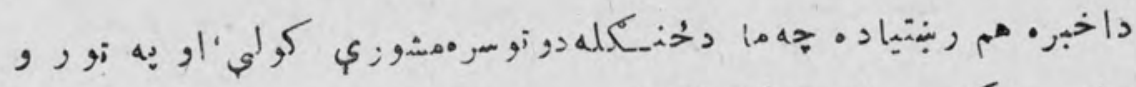

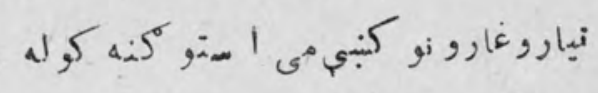

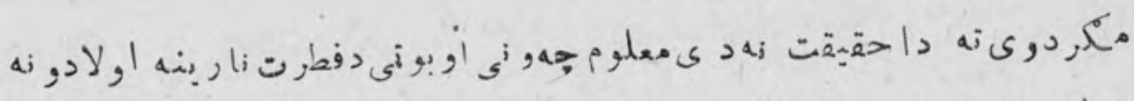

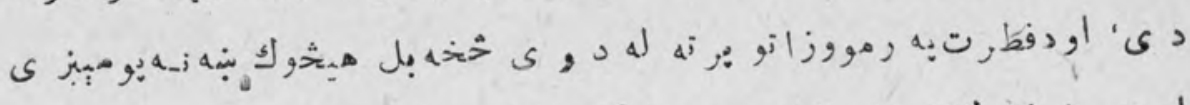

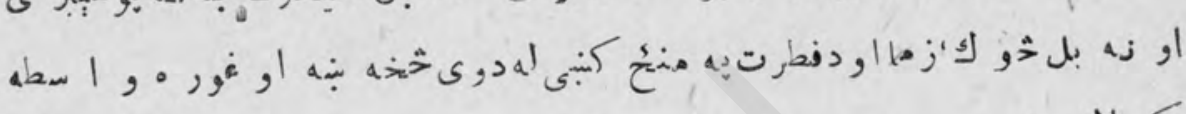

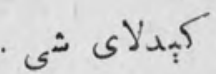

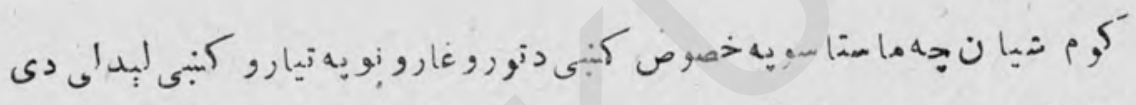

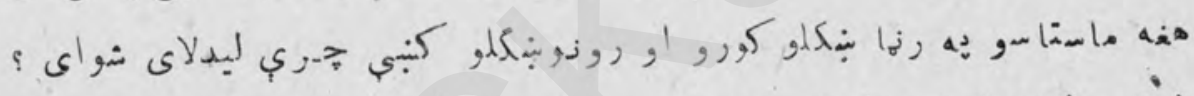

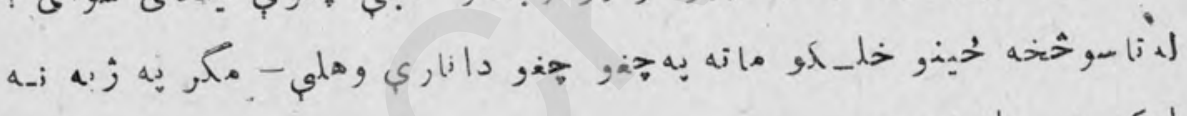
.

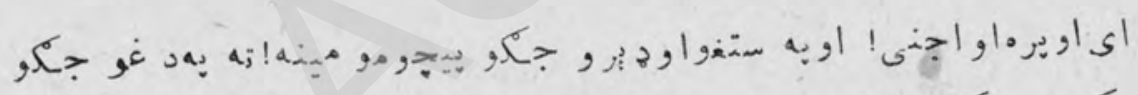

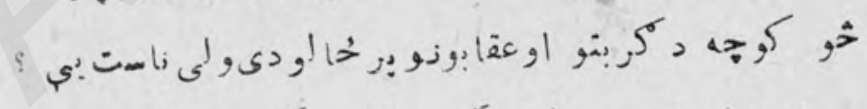
لها

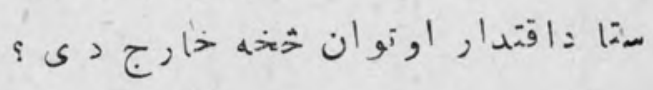

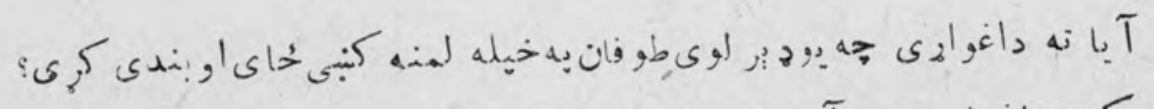

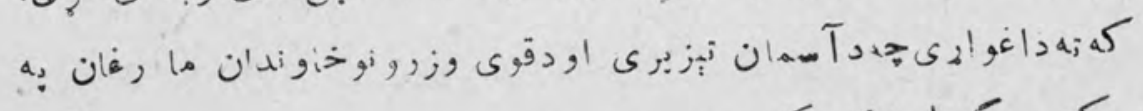

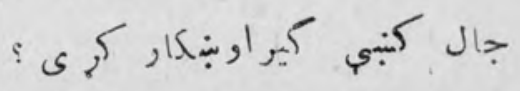

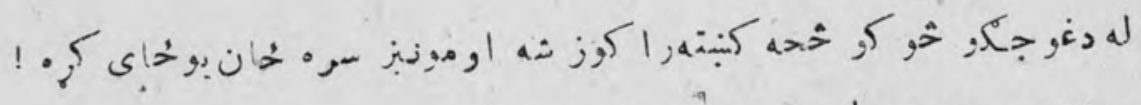

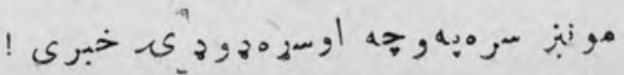




\section{(4)}

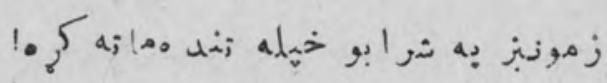

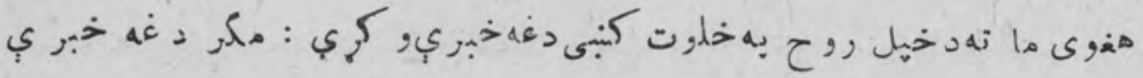

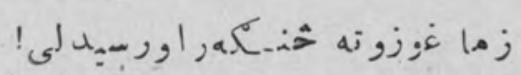

ها, إيد J جه دهis

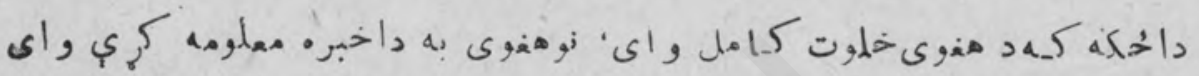

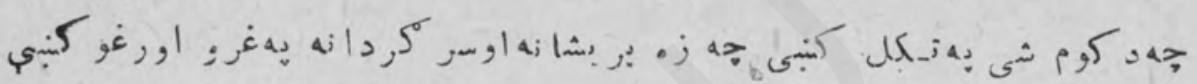
كرز

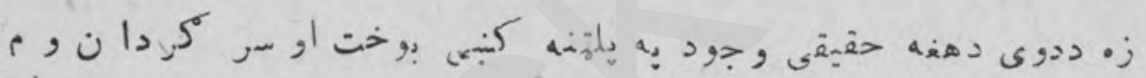

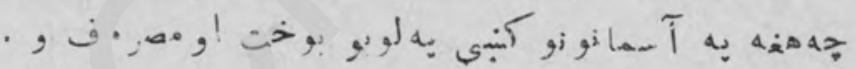

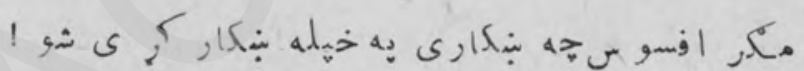

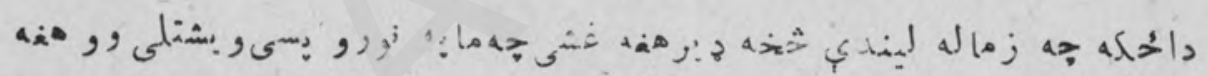

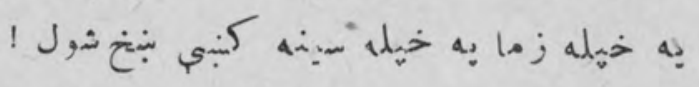

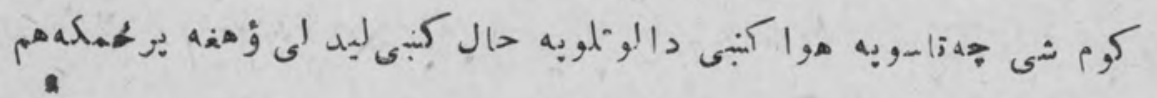

1.

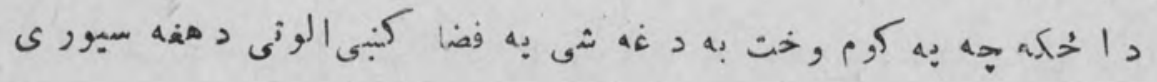

$$
\text { . } 4 \text { il }
$$

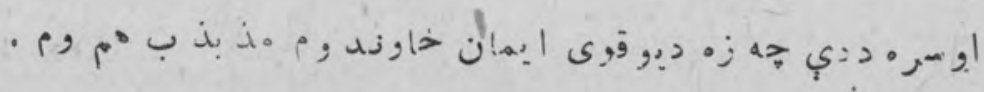

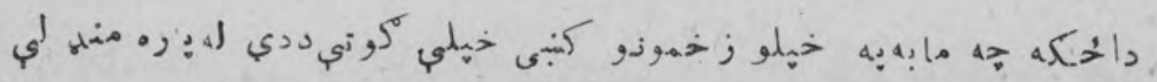

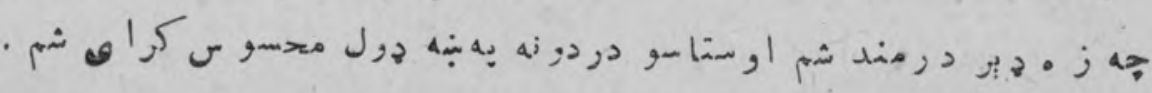




\section{0}

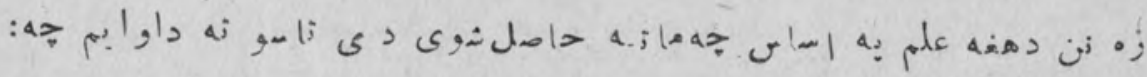

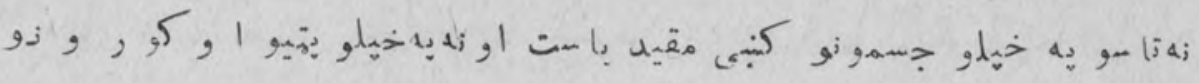

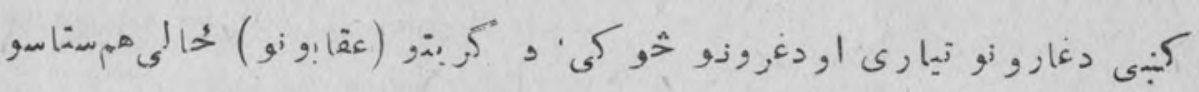

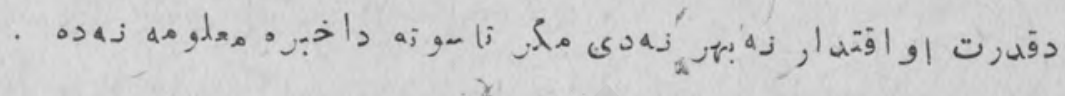

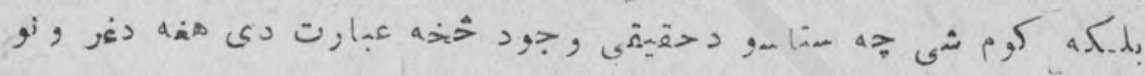

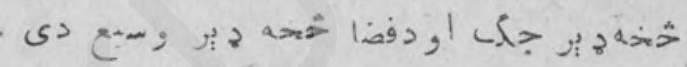

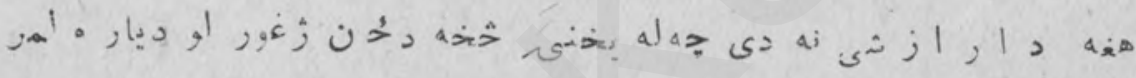

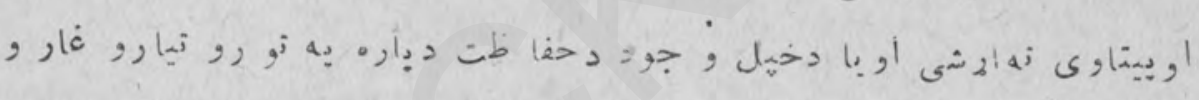
كنبي بتشى

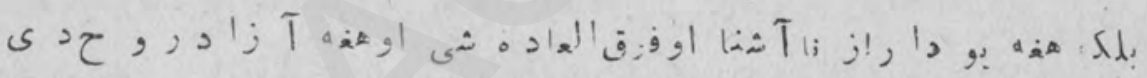

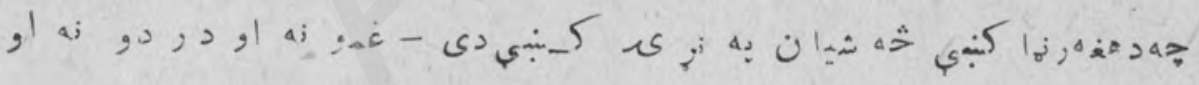

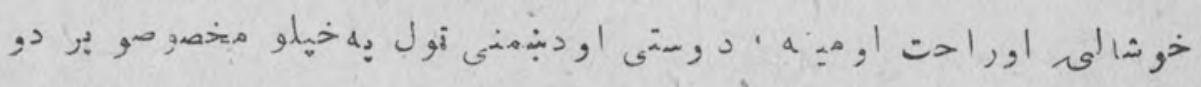
كبي , كن

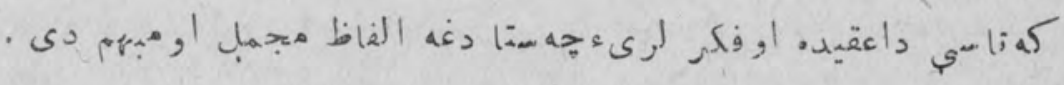

$$
\begin{aligned}
& \text { و }
\end{aligned}
$$

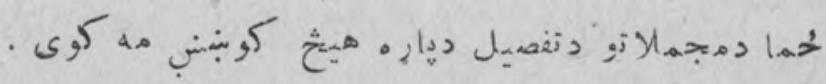

定

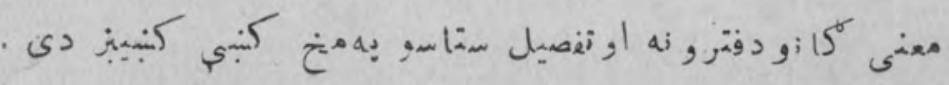




\section{(99)}

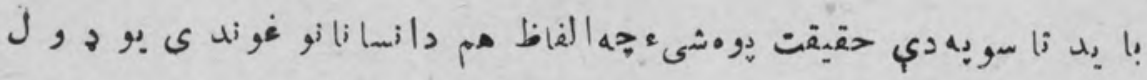

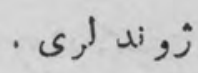

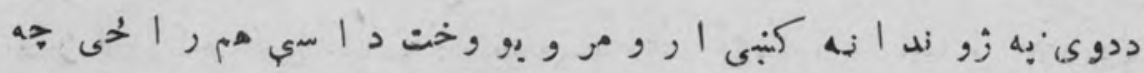

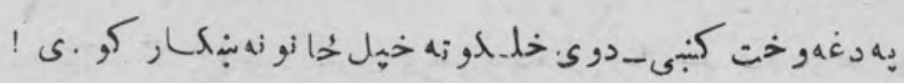

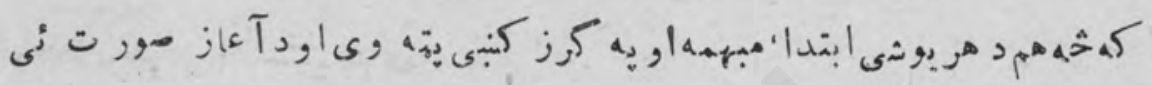
غيرهعين وى .

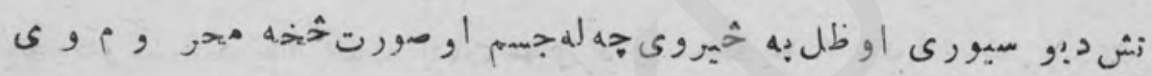

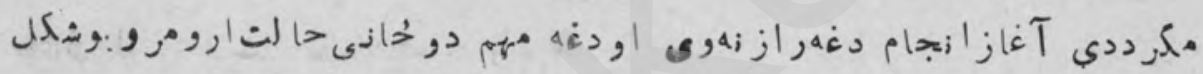

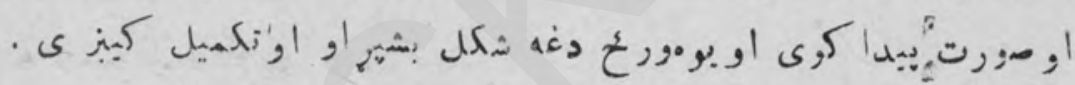

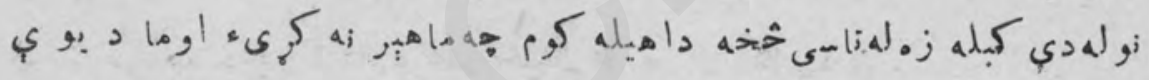

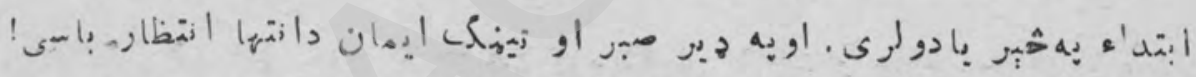

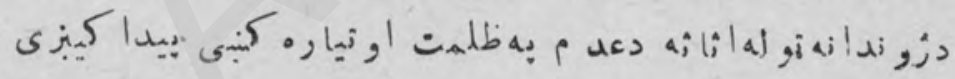

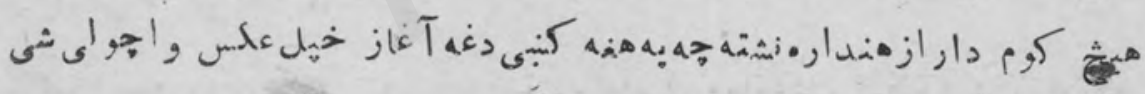

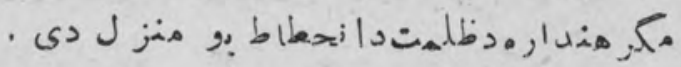

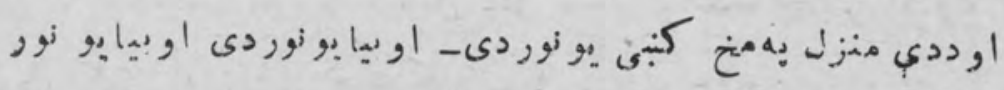

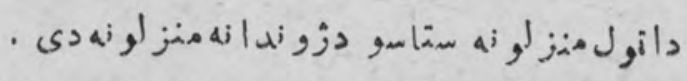

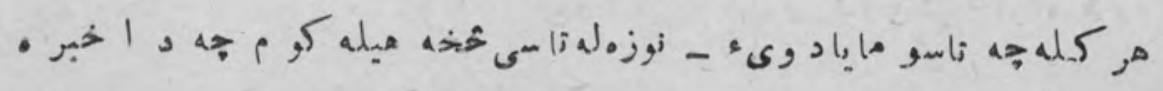
. 5 .

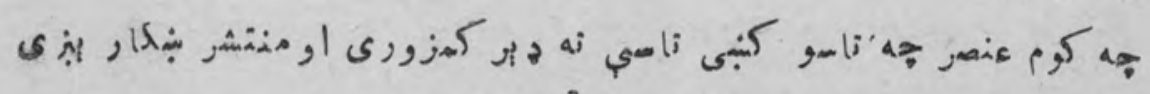

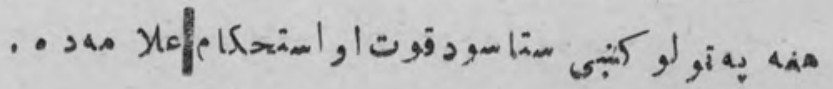




\section{$4+\infty$}

\section{(av)}

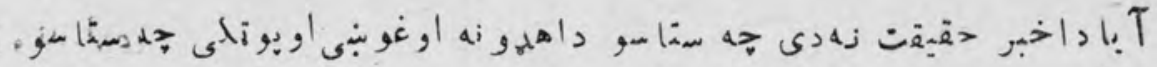

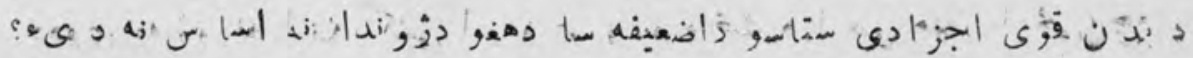

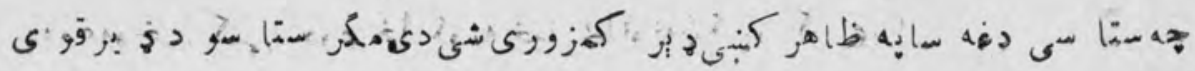

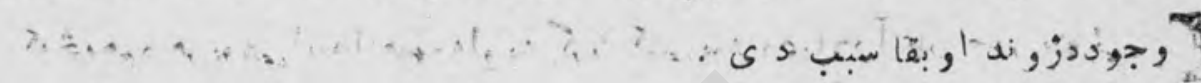

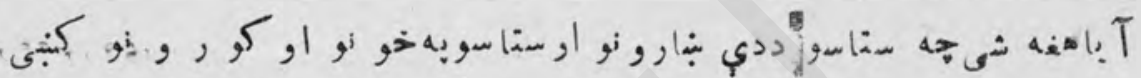

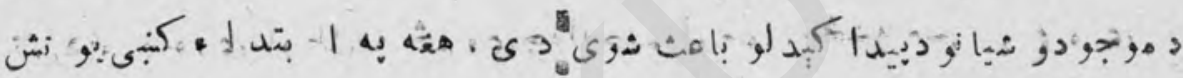

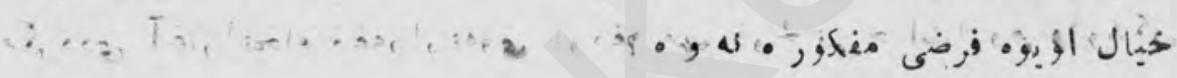

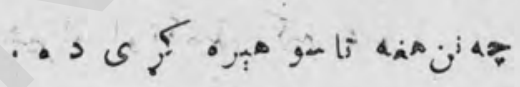

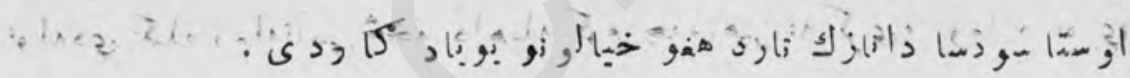

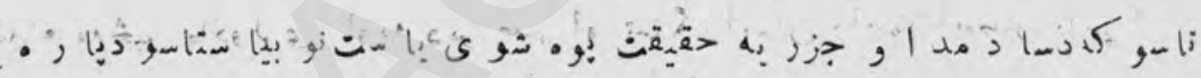

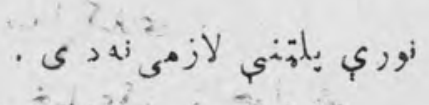

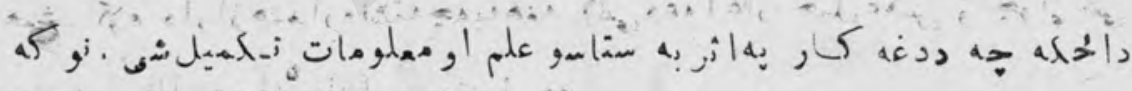

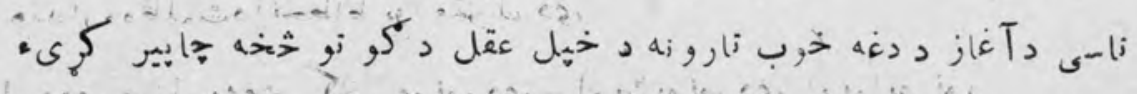

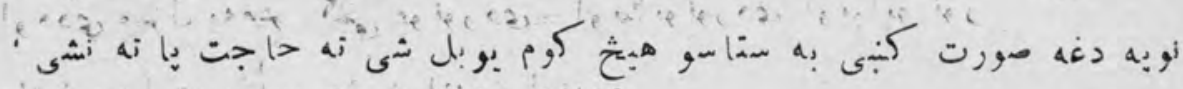

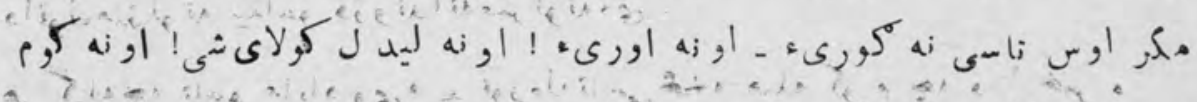

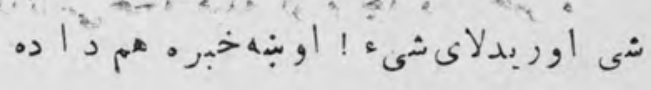

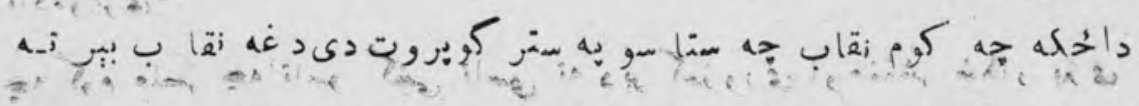

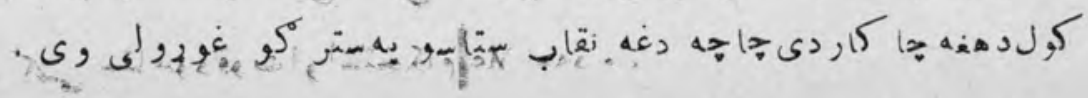

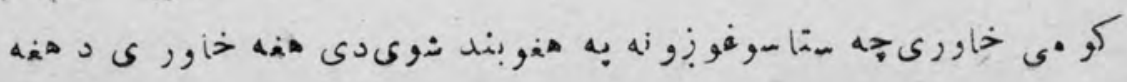




\section{(a)}

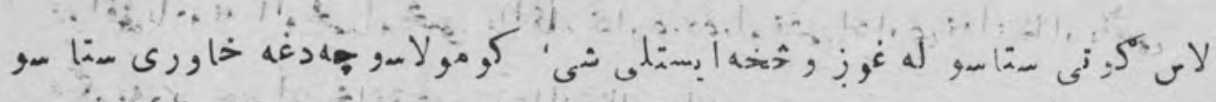

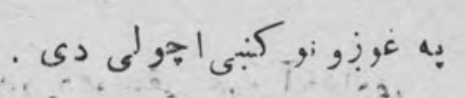

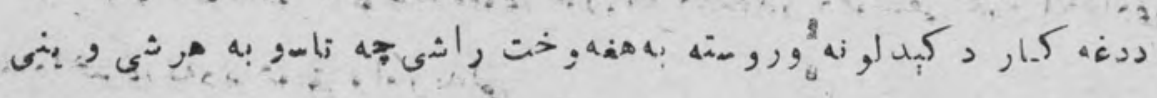

\section{او 'ورى ا}

\section{هرخه إورى إنه}

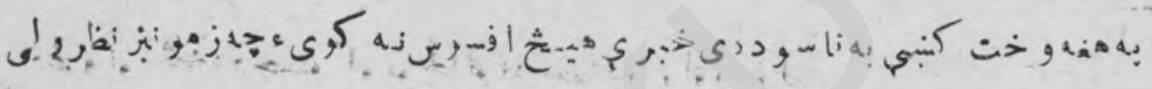

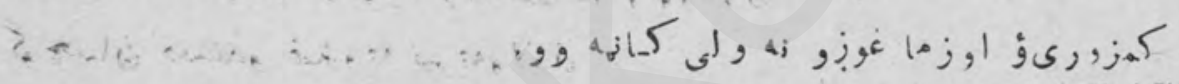

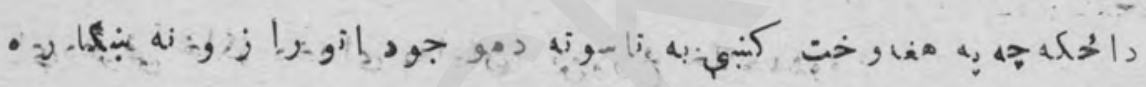
7. .....

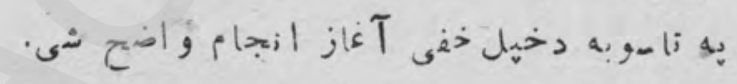

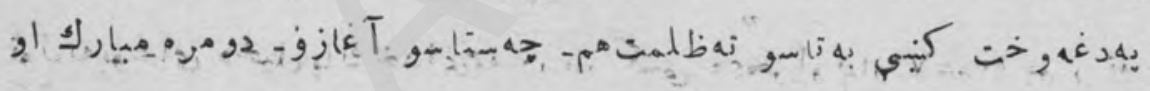

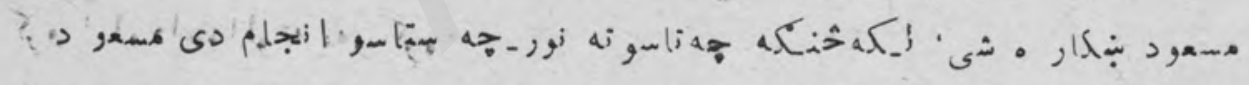

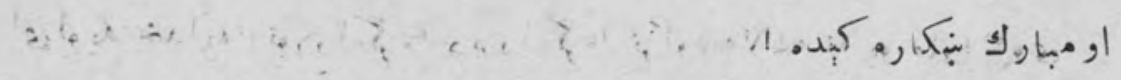

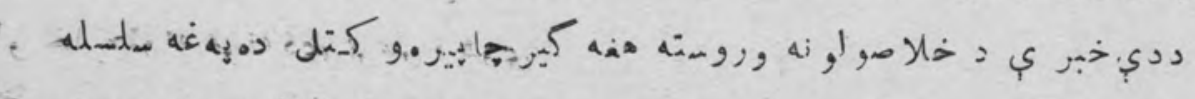

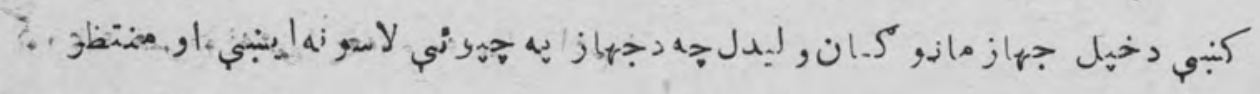

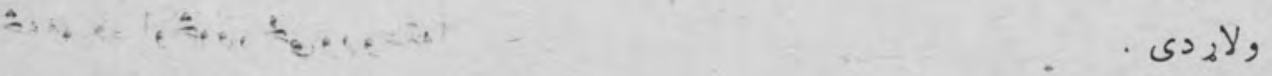

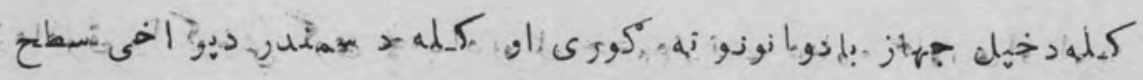

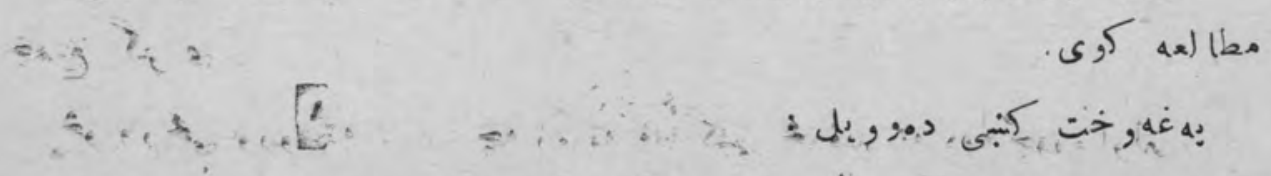

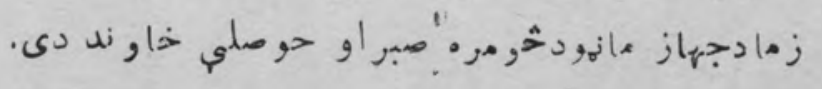




\section{(99)}

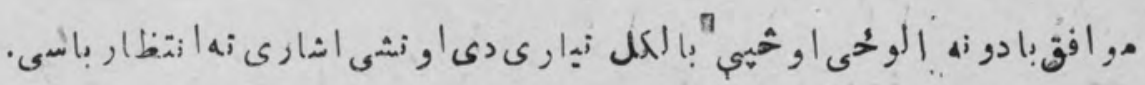

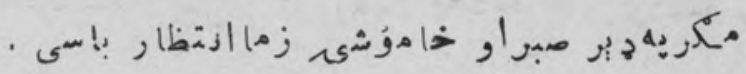

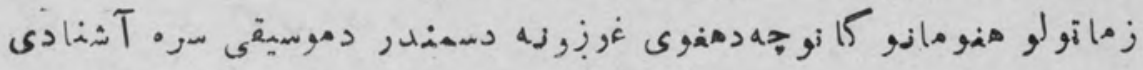

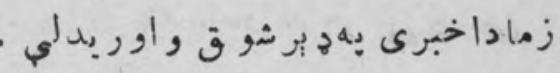

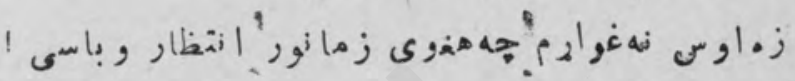

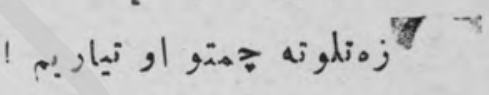

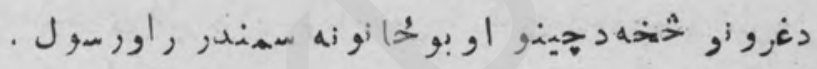

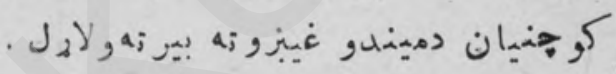

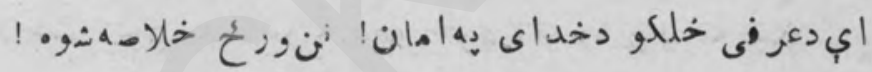

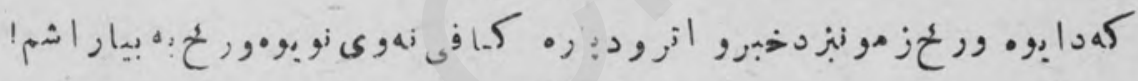

$$
\begin{aligned}
& \text { F. }
\end{aligned}
$$

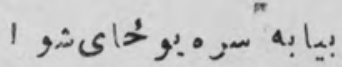

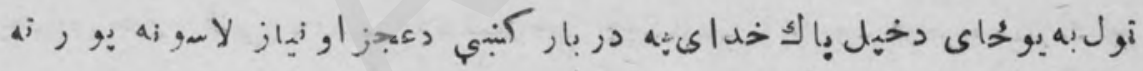

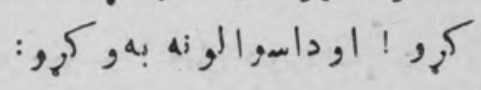

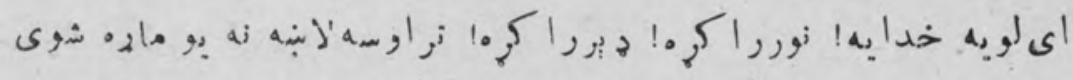

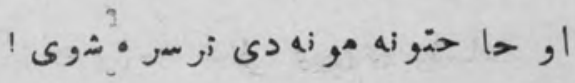

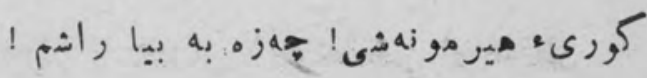

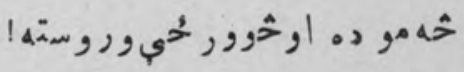

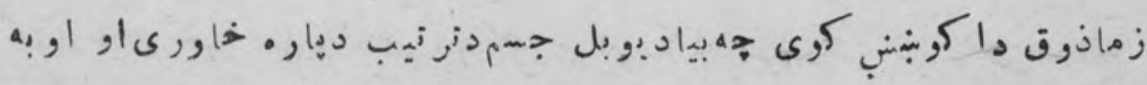

$$
\text { - }
$$

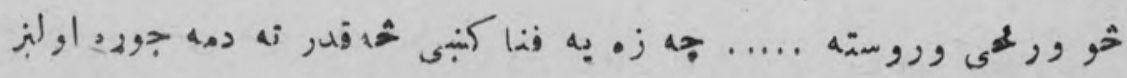




$$
\begin{aligned}
& \text { (1..) }
\end{aligned}
$$

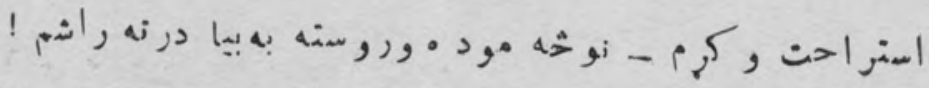

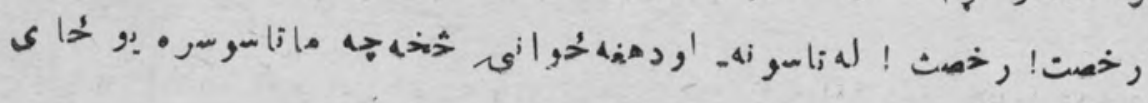

تير ك. 10.

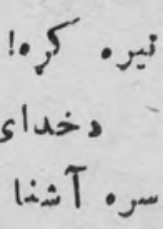

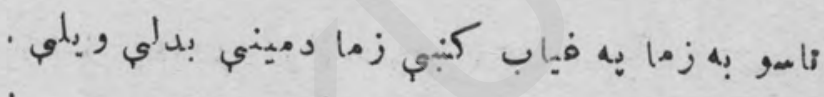

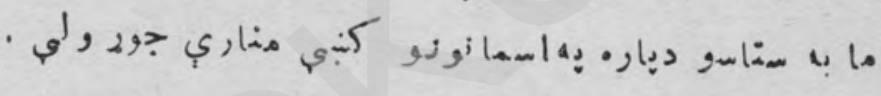

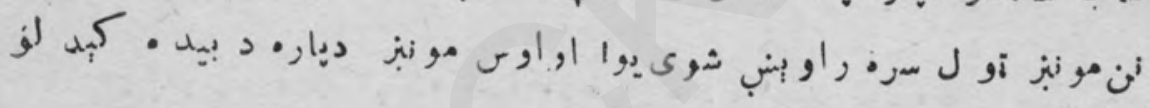

$$
\text { سر. آثنا شورى بوان. }
$$

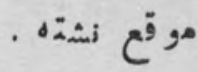
دالحكه جه لهر راختلى دى.

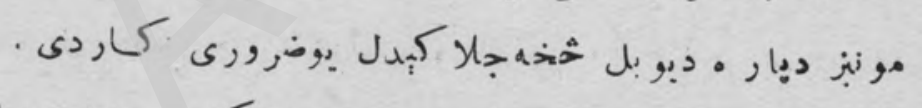

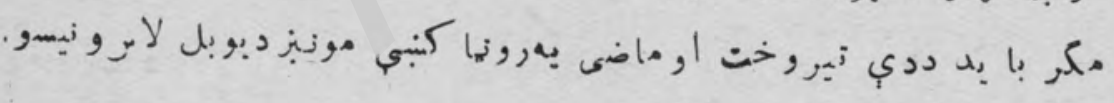

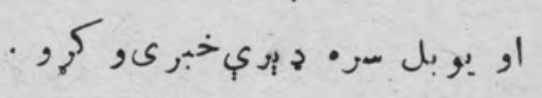

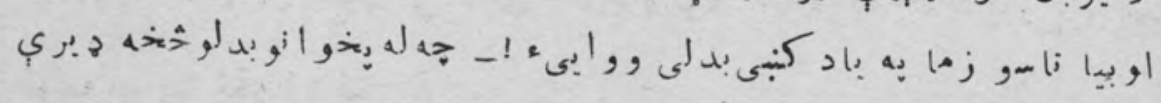

خوزي وى

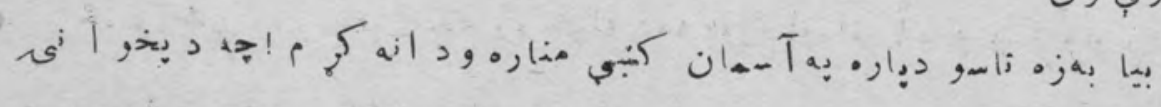

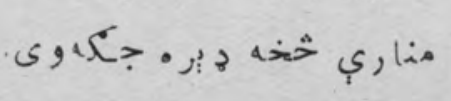

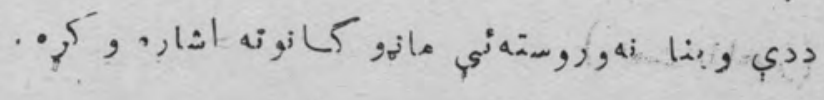
$-9$.

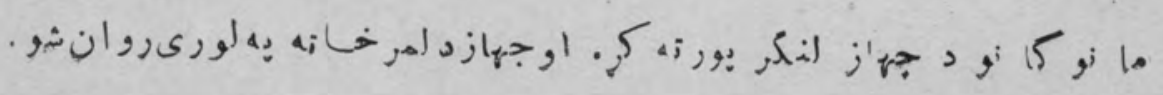




\section{$(1.1$.}

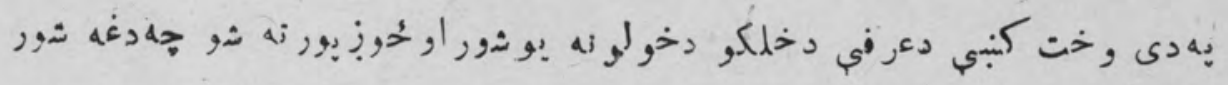

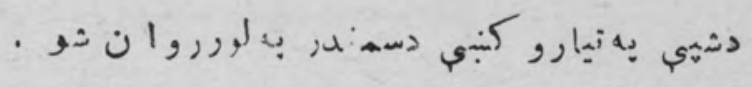

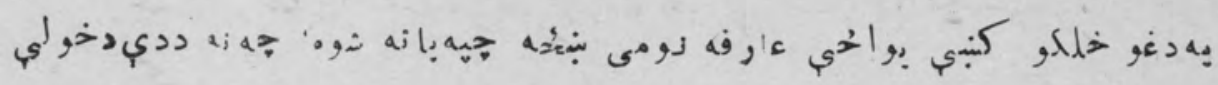

$$
\text { ! }
$$

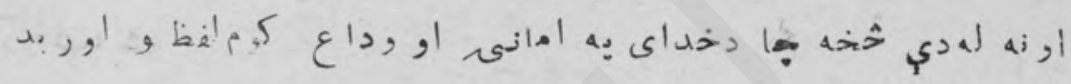

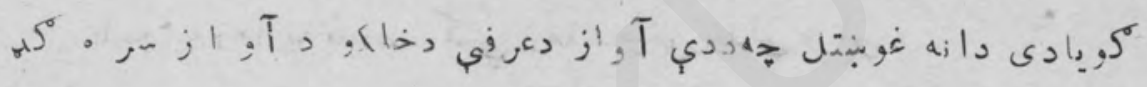

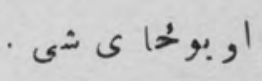

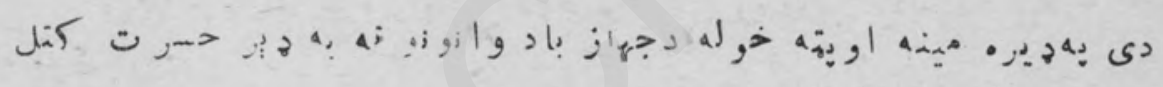

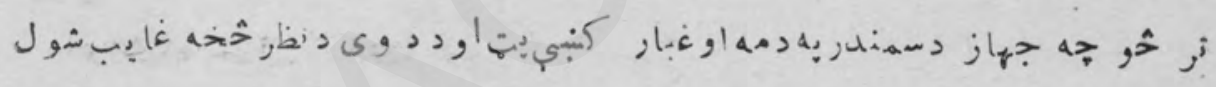

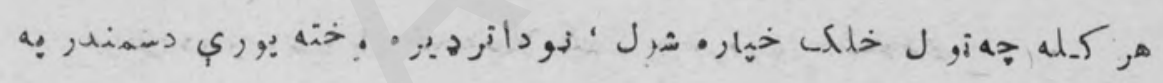
$\cdot \cdot, \cdot \cdot_{2}{ }^{\prime},{ }_{2} l 6$

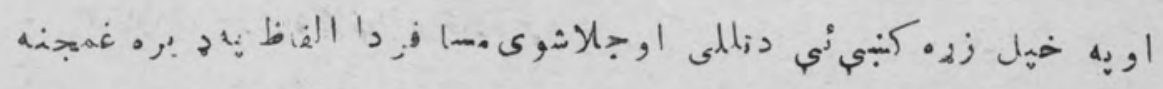

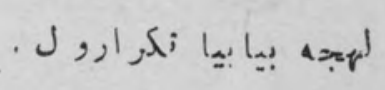

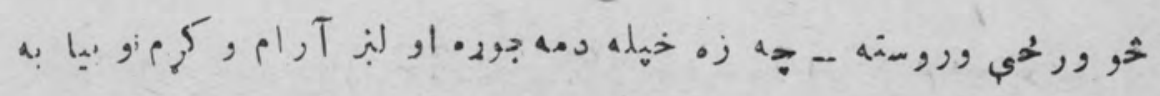

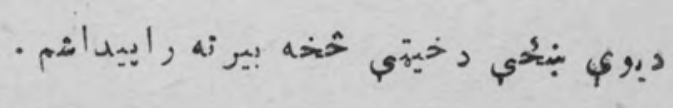

(i) (بs) 


\section{(ن)}

\begin{tabular}{|c|c|c|c|}
\hline 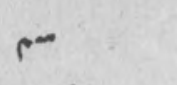 & ; & كربه & $\dot{\tau}$ \\
\hline أ: & زا تز & - & r \\
\hline خو ا & هi & 9 & $\varepsilon$ \\
\hline وعد. & ede, & 2 & 。 \\
\hline جيه اوغلي & جب إو على & $\varepsilon$ & . 1 \\
\hline مينه & ميه & $1 i$ & $\therefore$ \\
\hline مشكالات & . & 19 & 1. \\
\hline I, & خوا & 10 & 11 \\
\hline iो & $42 \infty$ & 17 & $1 r$ \\
\hline 4 & - & 1. & 17 \\
\hline , & ار & 7 & 1: \\
\hline خوددارى & خودارى & $\varepsilon$ & r \\
\hline خ & ? & 1 & r \\
\hline جو 2 & ج & 11 & $r$ \\
\hline ali & ali, & C 2 & $\varepsilon r$ \\
\hline 8 & : & $r$ & ०. \\
\hline s & ज्य & ir & YY \\
\hline i! & 26 & Ir & r \\
\hline 19 & م, & Ir & $\wedge r$ \\
\hline 4 & , & $1 \varepsilon$ & $\wedge r$ \\
\hline
\end{tabular}




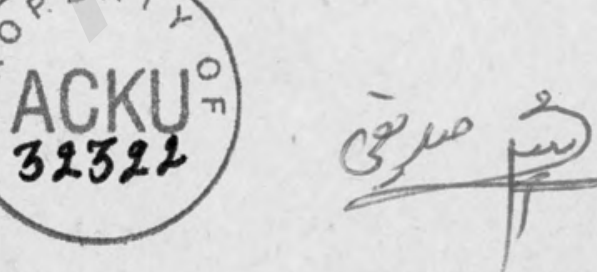
$154019 / 5$. 


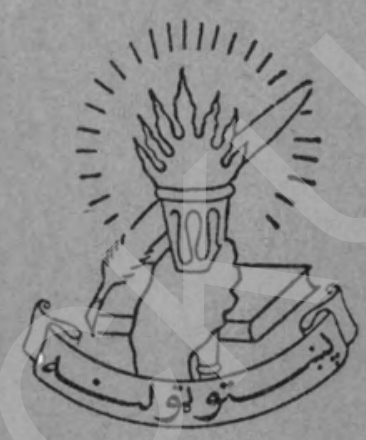

مطندونَّ 